\title{
Archeological Investigations for Fort Stabilization and Restoration, For McKavett State Historical Park, Menard County, Texas: 1978-1990 Seasons
}

Amy C. Earls

Prewitt and Associates, Inc.

John Leffler

Prewitt and Associates, Inc.

Follow this and additional works at: https://scholarworks.sfasu.edu/ita

Part of the American Material Culture Commons, Archaeological Anthropology Commons, Environmental Studies Commons, Other American Studies Commons, Other Arts and Humanities Commons, Other History of Art, Architecture, and Archaeology Commons, and the United States History Commons

Tell us how this article helped you.

This Article is brought to you for free and open access by the Center for Regional Heritage Research at SFA ScholarWorks. It has been accepted for inclusion in Index of Texas Archaeology: Open Access Gray Literature from the Lone Star State by an authorized editor of SFA ScholarWorks. For more information, please contact cdsscholarworks@sfasu.edu. 


\section{Archeological Investigations for Fort Stabilization and Restoration, For McKavett}

State Historical Park, Menard County, Texas: 1978-1990 Seasons

\section{Creative Commons License}

\section{(c) (i) $\Theta($}

This work is licensed under a Creative Commons Attribution-NonCommercial-No Derivative Works 4.0 International License. 


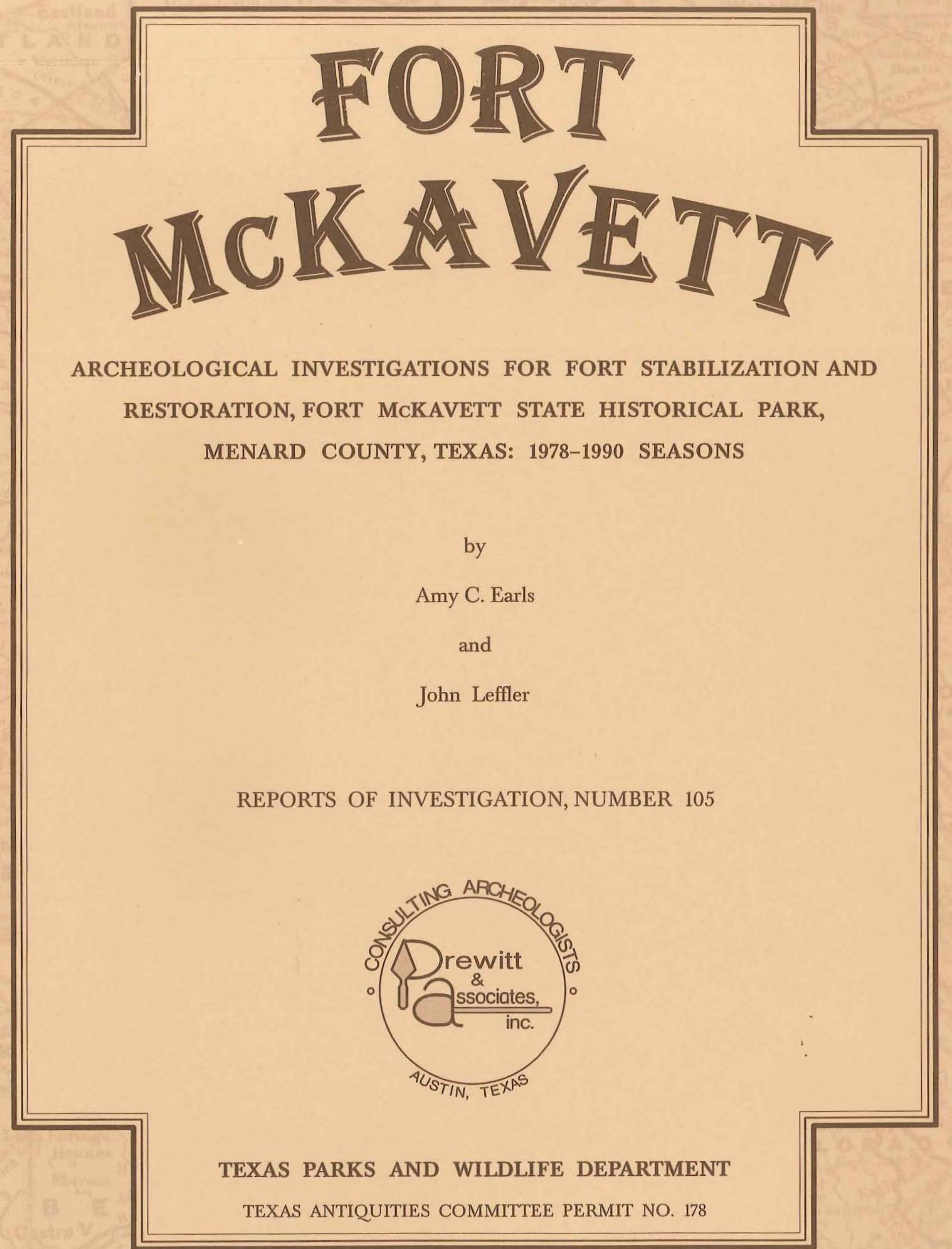




\title{
ARCHEOLOGICAL INVESTIGATIONS FOR FORT STABILIZATION AND RESTORATION, FORT MCKAVETT STATE HISTORICAL PARK, MENARD COUNTY, TEXAS: 1978-1990 SEASONS
}

by

\author{
Amy C. Earls \\ and \\ John Leffler \\ with Contributions by \\ George Kegley \\ and \\ Brian S. Shaffer \\ Principal Investigators: Elton R. Prewitt, Amy C. Earls, and Art Black
}

REPORTS OF INVESTIGATIONS, NUMBER 105

Prewitt and Associates, Inc.

Consulting Archeologists

Austin, Texas

March 1996

TEXAS ANTIQUITIES COMMITTEE PERMIT NO. 178 
CONTRACT DATA

The preparation of this document was accomplished under a Memorandum of Agreement dated 8 July 1994 with the Texas Parks and Wildlife Department, 4200 Smith School Road, Austin, Texas 78744. 


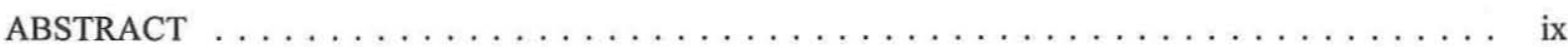

ACKNOWLEDGMENTS $\ldots \ldots \ldots \ldots \ldots \ldots \ldots \ldots \ldots \ldots \ldots \ldots \ldots \ldots \ldots \ldots \ldots$

CHAPTER 1: INTRODUCTION AND BACKGROUND $\ldots \ldots \ldots \ldots \ldots \ldots \ldots \ldots \ldots \ldots$

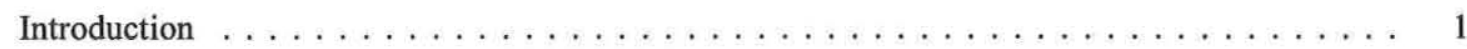

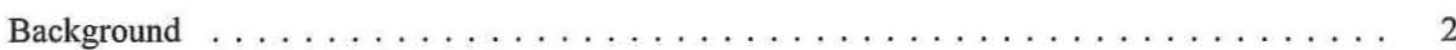

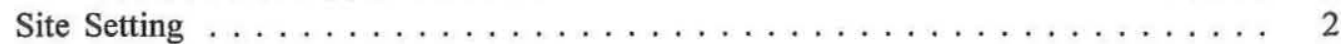

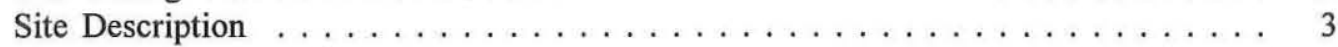

Previous Archeological Investigations $\ldots \ldots \ldots \ldots \ldots \ldots \ldots \ldots \ldots \ldots \ldots$

CHAPTER 2: HISTORICAL BACKGROUND $\ldots \ldots \ldots \ldots \ldots \ldots \ldots \ldots \ldots \ldots$

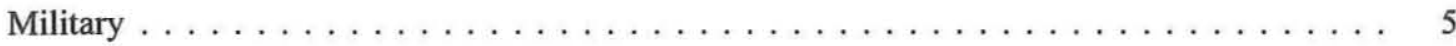

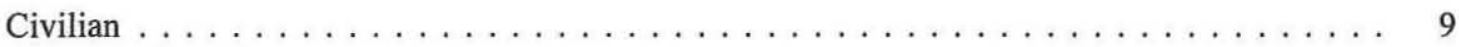

The Origins of the Fort McKavett Community . . . . . . . . . . . . 9

The Development of the Town of Fort McKavett, 1883-1900 . . . . . . . . . . 12

The Development of Fort McKavett, $1900-1940 \ldots \ldots$. . . . . . . . . . . . . 19

The Last Years of the Town . . . . . . . . . . . . . . . . . 23

CHAPTER 3: RESEARCH DESIGN AND METHODS $\ldots \ldots \ldots \ldots \ldots \ldots \ldots \ldots \ldots$

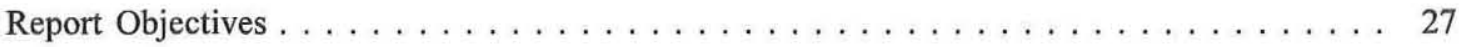

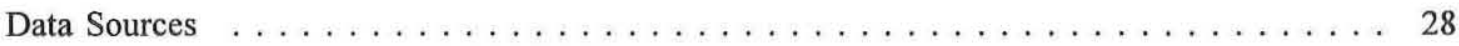

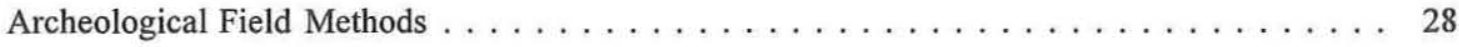

Analytical Techniques and Limitations . . . . . . . . . . . . . . . . . . 29

Military and Military-Period Artifact Definitions $\ldots \ldots \ldots \ldots \ldots \ldots \ldots$

Military Artifact Analysis . . . . . . . . . . . . . . . . . . . . . 30

Ceramic Analysis . . . . . . . . . . . . . . . . . . . 30

Bottle Analysis . . . . . . . . . . . . . . . . . . . . . 31

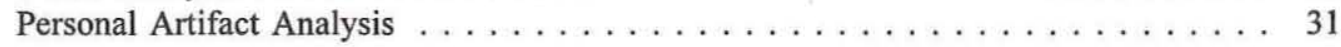

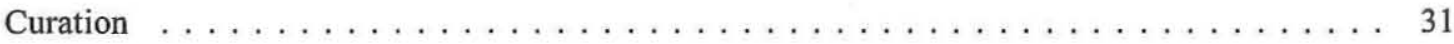

CHAPTER 4: STRUCTURES AND FEATURES $\ldots \ldots \ldots \ldots \ldots \ldots \ldots \ldots \ldots \ldots$

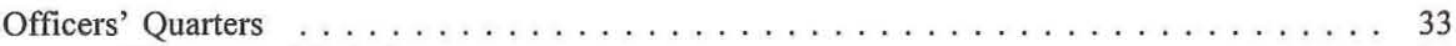

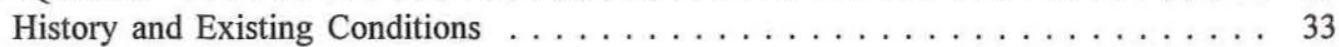

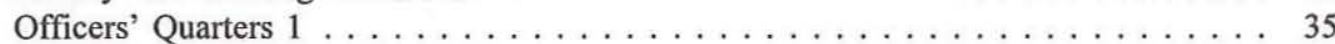

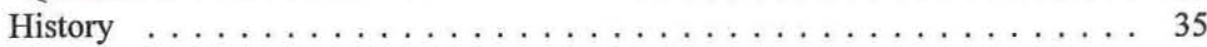

Archeological Results . . . . . . . . . . . . . . . . 39

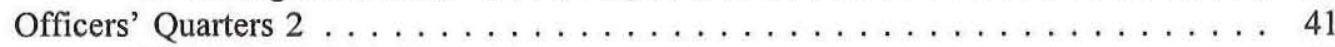

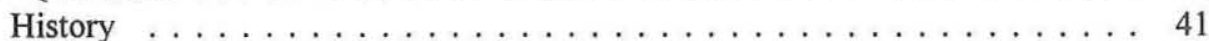

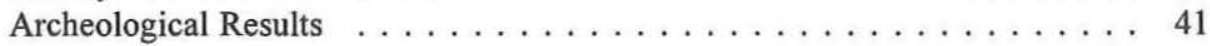

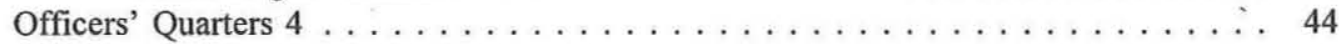

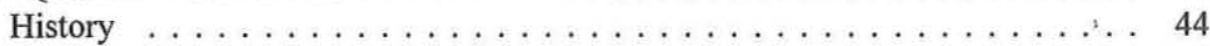

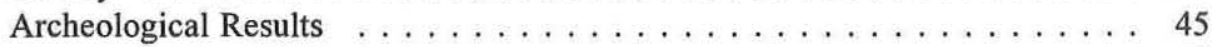

Officers' Quarters $4-5 \ldots \ldots \ldots \ldots \ldots \ldots \ldots \ldots$

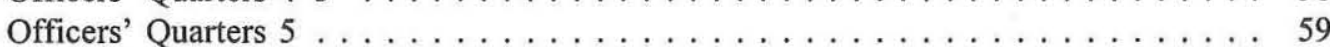

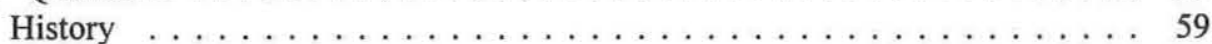

Archeological Results . . . . . . . . . . . . . . . . 60 


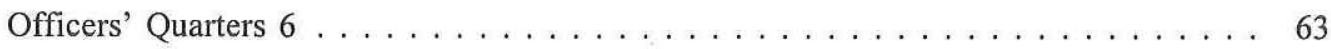

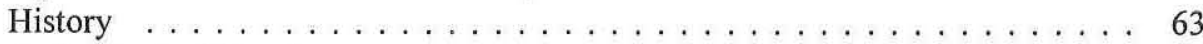

Archeological Results . . . . . . . . . . . . . . . . . . 64

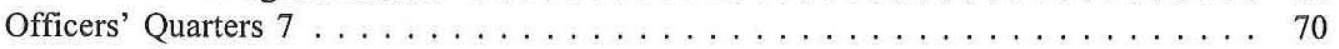

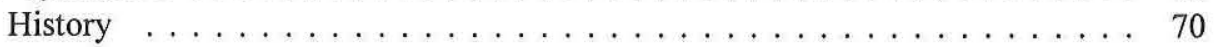

Archeological Results . . . . . . . . . . . . . . . . . . 71

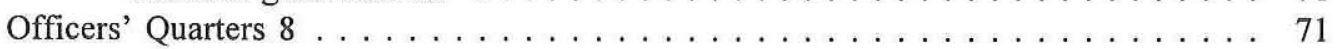

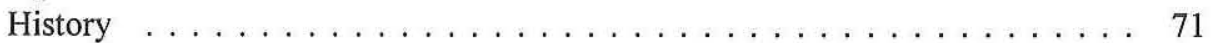

Archeological Results . . . . . . . . . . . . . . . . . . 72

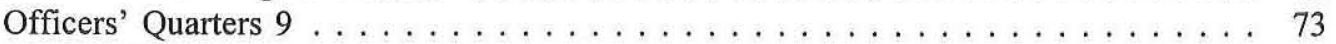

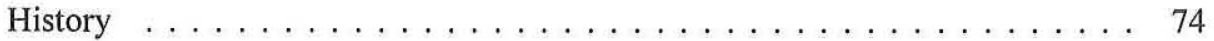

Archeological Results . . . . . . . . . . . . . . . . . . . 74

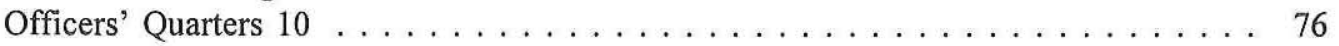

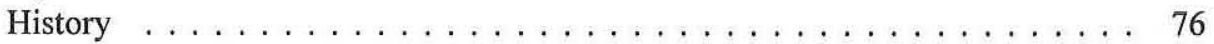

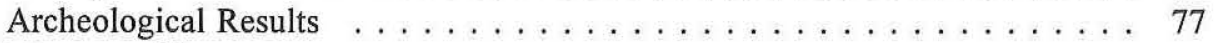

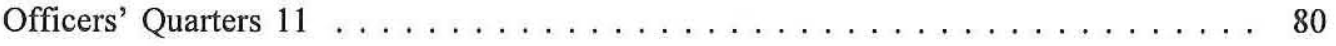

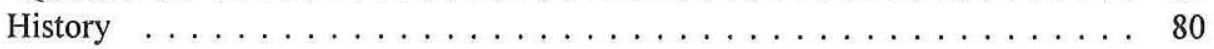

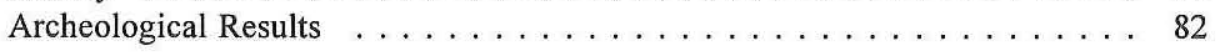

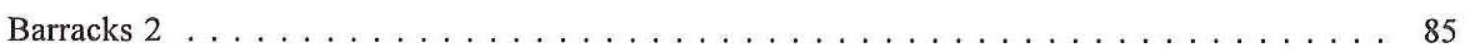

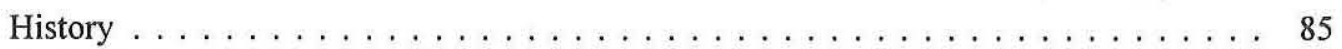

Archeological Results . . . . . . . . . . . . . . . . . . . . . 85

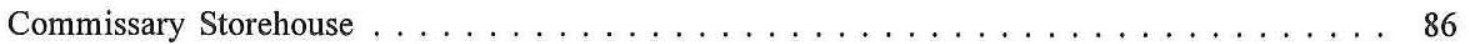

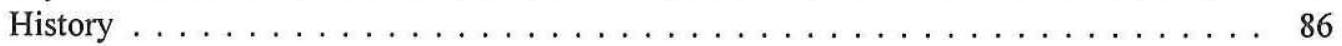

Archeological Results . . . . . . . . . . . . . . . . . . . . . . 87

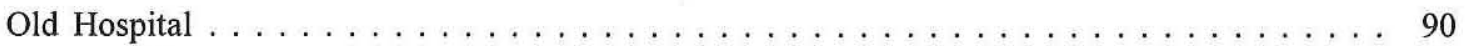

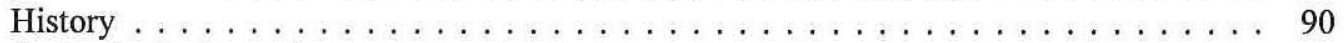

Archeological Results . . . . . . . . . . . . . . . . . . . . 92

Schoolhouse . . . . . . . . . . . . . . . . . . . . . . . . . 94

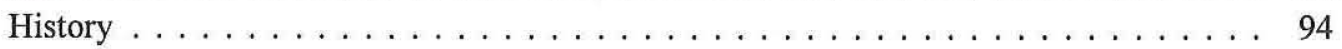

Archeological Results . . . . . . . . . . . . . . . . . . . . 95

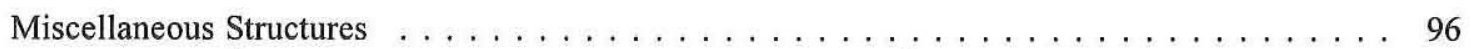

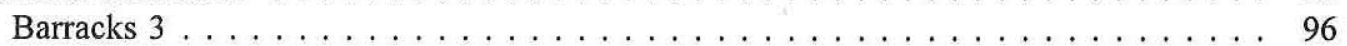

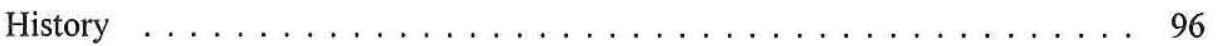

Archeological Results . . . . . . . . . . . . . . . . . . . 97

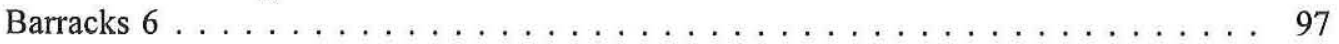

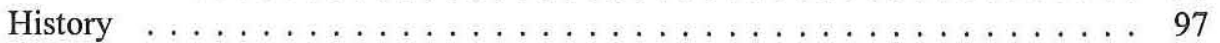

Archeological Results . . . . . . . . . . . . . . . . . . . 97

Farm to Market Road 864 Reroute Right-of-Way . . . . . . . . . . . . . . . . 98

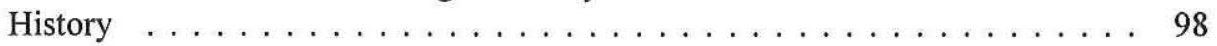

Archeological Results . . . . . . . . . . . . . . . . . 98

Lime Kiln . . . . . . . . . . . . . . . . . . . . . . . 98

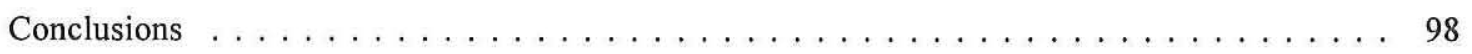

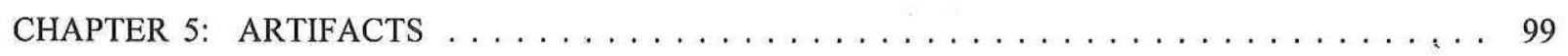

Military Artifacts . . . . . . . . . . . . . . . . . . . . . . 99

Arms and Ammunition . . . . . . . . . . . . . . . . . . . . . 99

Firearms . . . . . . . . . . . . . . . . . . . . . . . . 99

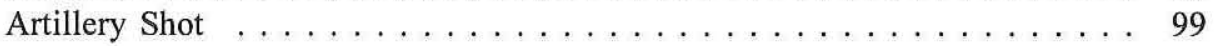

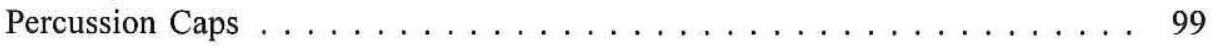


Conical Bullets and Shot . . . . . . . . . . . . . . . . . . . . 99

Cartridge Cases . . . . . . . . . . . . . . . . . . . . . . . 100

Clothing and Insignia . . . . . . . . . . . . . . . . . . . . 107

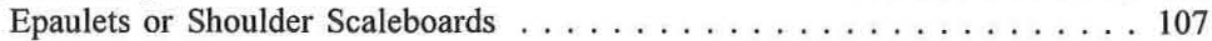

Insignia . . . . . . . . . . . . . . . . . . . . . . 107

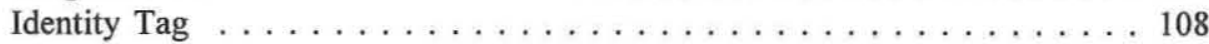

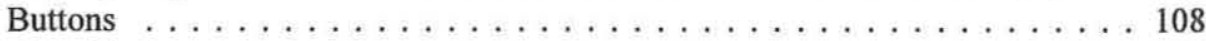

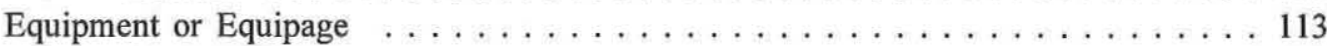

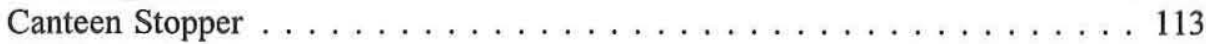

Carbine Sling Swivel . . . . . . . . . . . . . . . . . . . . . . . . 114

Knapsack Hardware . . . . . . . . . . . . . . . . . . . . . . . . . . . . 114

Buckles . . . . . . . . . . . . . . . . . . . . . . . . . 114

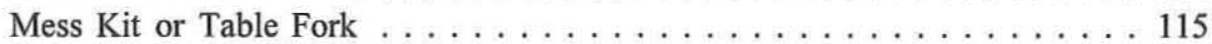

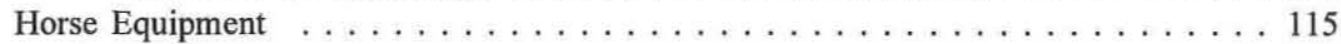

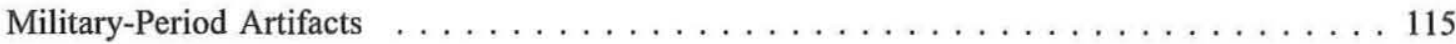

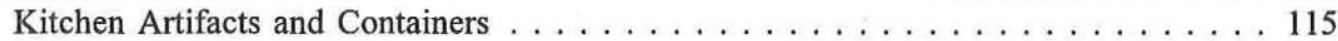

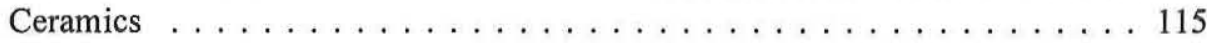

Bottle Glass . . . . . . . . . . . . . . . . . . . . . . . . 125

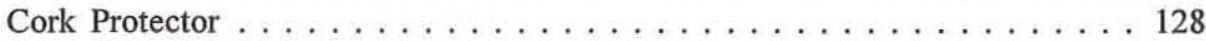

Table Glass . . . . . . . . . . . . . . . . . . . . . . . . . . 128

Clothing . . . . . . . . . . . . . . . . . . . . . . . . 129

Tobacco-Related Artifacts . . . . . . . . . . . . . . . . . . . . . . . . . . . 129

Tobacco Pipes . . . . . . . . . . . . . . . . . . . . . . . . 129

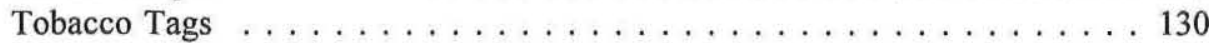

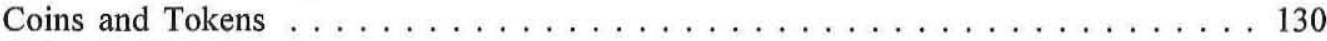

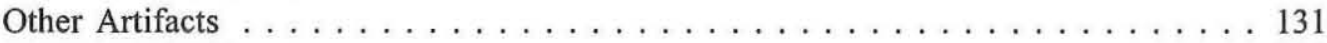

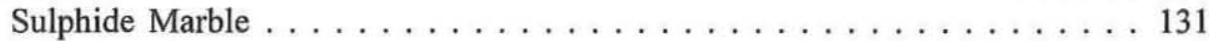

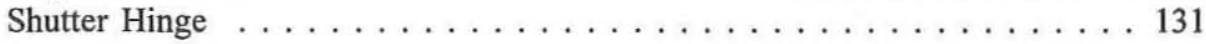

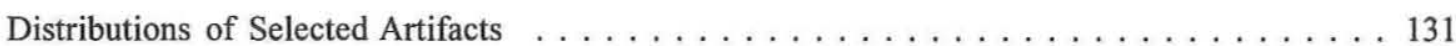

Military Artifacts . . . . . . . . . . . . . . . . . . 131

Ceramics . . . . . . . . . . . . . . . . . . . . . . 132

Bottle Glass . . . . . . . . . . . . . . . . . . . . . . . . . . . . . 133

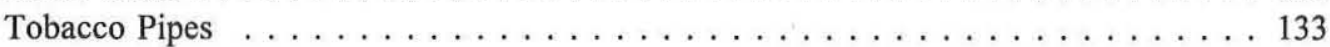

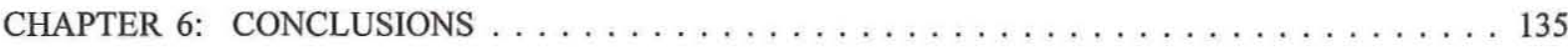

Comparisons with Previous Archeological Investigations at Fort McKavett $\ldots \ldots \ldots \ldots 135$

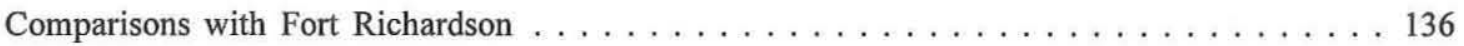

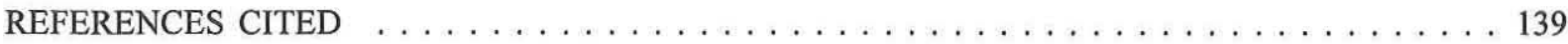

APPENDIX A: Inventory of Military and Military-Period Artifacts $\ldots \ldots \ldots \ldots \ldots$

APPENDIX B: Functional Classification of the Fort McKavett Military and Civilian Artifact Collection

George Kegley . . . . . . . . . . . . . . . . . . . . . . . . 157

APPENDIX C: The Sprague Code Artifact Classification as Modified by the Texas Parks and Wildlife Department

George Kegley . . . . . . . . . . . . . . . . . . . . . . . . . . 169

APPENDIX D: Analysis of the Archeovertebrate Remains from Officers' Quarters 4

Brian S. Shaffer 


\section{LIST OF FIGURES}

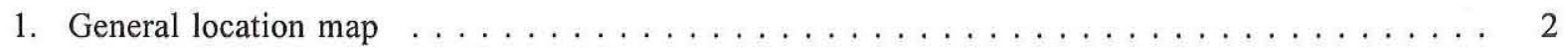

2. Military forts and frontier settlement in the mid nineteenth century $\ldots \ldots \ldots \ldots \ldots$

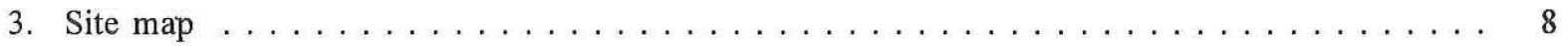

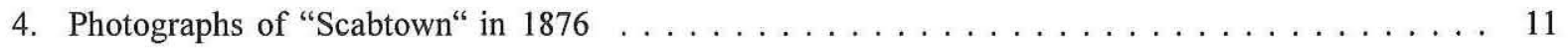

5. Advertisements for the Fritz Mayer store and the Traweek House hotel $\ldots \ldots \ldots \ldots$

6. Photograph of school class at Fort McKavett, $1894 \ldots \ldots \ldots \ldots \ldots \ldots$

7. Photograph of the "Saucedo House" in eastern section of Fort McKavett $\ldots \ldots \ldots \ldots$

8. Photograph of items forged by J. D. Hodge, Fort McKavett's blacksmith in the 1920s . . . . . 22

9. Photograph of St. William's Catholic Church, built in $1947 \ldots \ldots \ldots \ldots \ldots$. . . . . . 24

10. Map entitled "Plan of Fort McKavett," ca. $1871 \ldots \ldots \ldots \ldots \ldots \ldots \ldots \ldots$

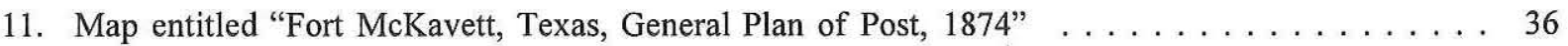

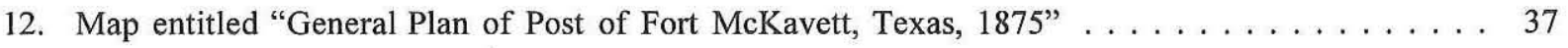

13. Map entitled "Plan of Fort McKavett, Texas, $1876 " \ldots \ldots \ldots \ldots \ldots \ldots$

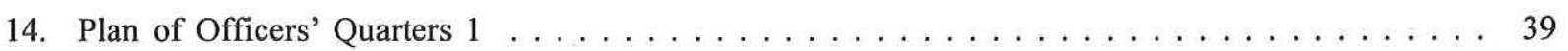

15. Photograph of Fort McKavett taken in $1912 \ldots \ldots \ldots \ldots \ldots \ldots \ldots \ldots \ldots \ldots \ldots \ldots$

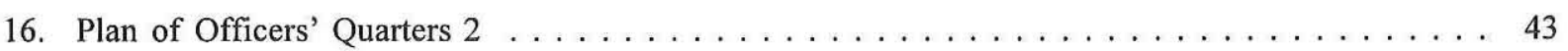

17. Photograph taken in 1911 of unoccupied Officers' Quarters $4 \ldots \ldots \ldots \ldots \ldots \ldots$

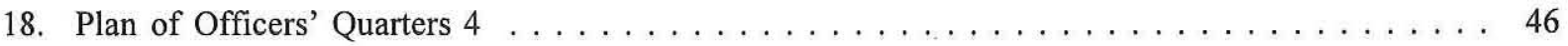

19. Profiles of Room 0 in Officers' Quarters $4 \ldots \ldots \ldots \ldots \ldots \ldots \ldots \ldots \ldots$

20. Plan of Room 1 of Officers' Quarters $4 \ldots \ldots \ldots \ldots \ldots \ldots \ldots \ldots$

21. Profiles of Room 1 of Officers' Quarters $4 \ldots \ldots \ldots \ldots \ldots \ldots \ldots \ldots \ldots \ldots$

22. Plan of Rooms 2 and 3 of Officers' Quarters $4 \ldots \ldots \ldots \ldots \ldots \ldots \ldots \ldots \ldots \ldots \ldots \ldots \ldots$

23. West wall profile of Unit 6 , Room 2, in Officers' Quarters $4 \ldots \ldots \ldots \ldots \ldots \ldots$

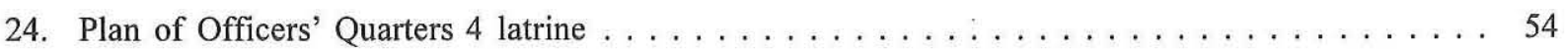

25. Plan of remnant front walkway of Officers' Quarters $4 \ldots \ldots \ldots \ldots \ldots \ldots \ldots \ldots$

26. Photograph taken in 1890 of Officers' Quarters 11,

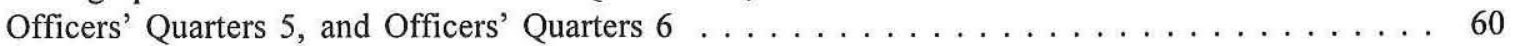

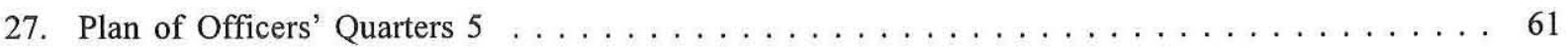

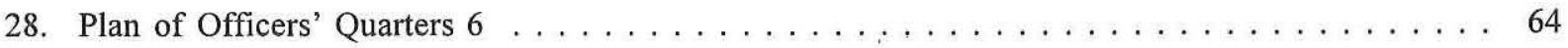

29. Plan of the south end of Room 1 in Officers' Quarters $6 \ldots \ldots \ldots \ldots \ldots \ldots \ldots \ldots \ldots \ldots$

30. West-facing profile in the vicinity of the fireplace in Room 1 in Officers' Quarters $6 \ldots \ldots 7$

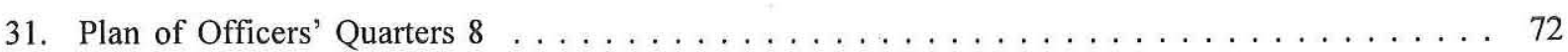

32. South profile of exterior doorsteps of Room 3 in Officers' Quarters $8 \ldots \ldots \ldots \ldots$

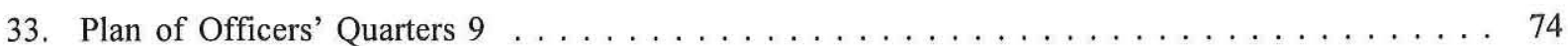


34. Photographs of Officers' Quarters $10 \ldots \ldots \ldots \ldots \ldots \ldots \ldots \ldots \ldots \ldots \ldots$

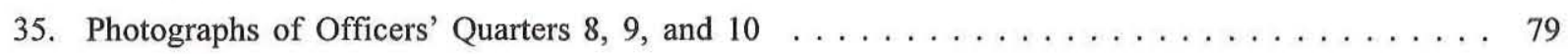

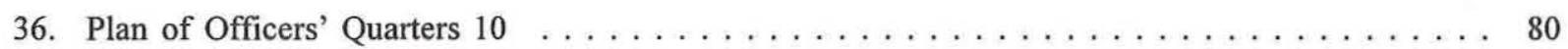

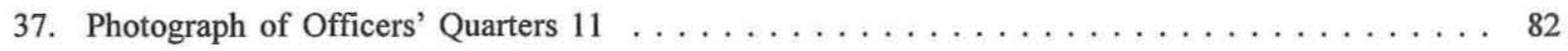

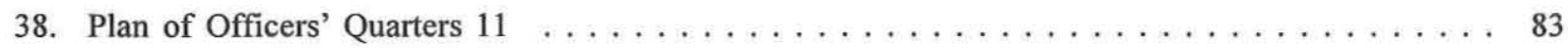

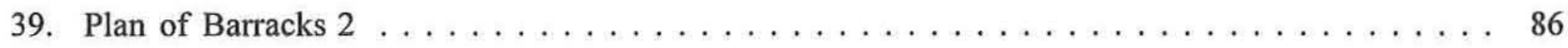

40. Plan of commissary storehouse $\ldots \ldots \ldots \ldots \ldots \ldots \ldots \ldots \ldots \ldots \ldots \ldots \ldots$

41. North profile of commissary storehouse, Units 6 , 5, and $3 \ldots \ldots \ldots \ldots$

42. Photograph taken in 1884 of frame hospital building $\ldots \ldots \ldots \ldots \ldots \ldots \ldots \ldots \ldots$

43. Plan of Old Hospital complex showing surface collection area and excavations $\ldots \ldots \ldots 3$

44. Plan of excavations on the north side of the schoolhouse $\ldots \ldots \ldots \ldots \ldots \ldots$

45. Tool marks on $.56-50$-caliber Spencer rimfire cartridge case heads $\ldots \ldots \ldots \ldots \ldots \ldots$

46. Cup-primed cartridge cases with early and late crimps $\ldots \ldots \ldots \ldots \ldots \ldots \ldots$

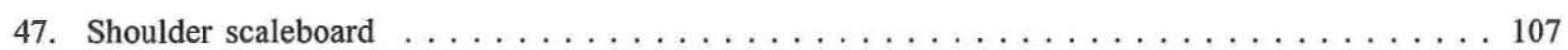

48. Large infantry bugle or hunting horn insignia $\ldots \ldots \ldots \ldots \ldots \ldots \ldots \ldots \ldots \ldots \ldots \ldots \ldots$

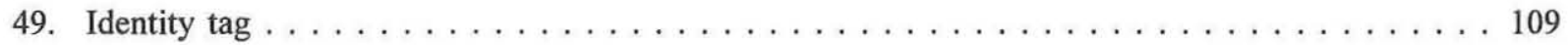

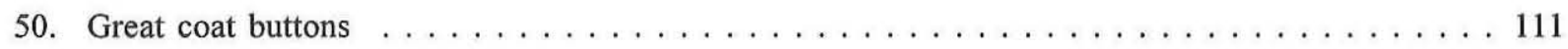

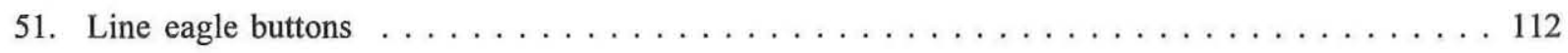

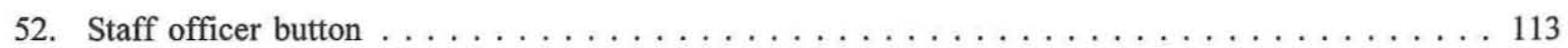

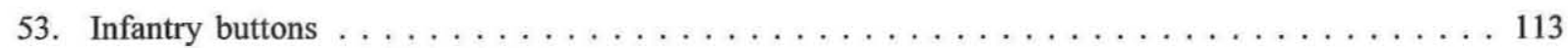

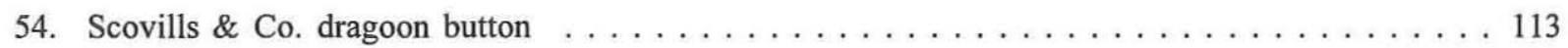

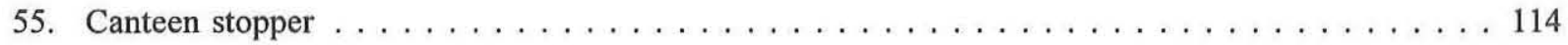

56. Red-printed whiteware with Edge Malkin \& Co. maker's and Verona pattern mark . . . . . . 119

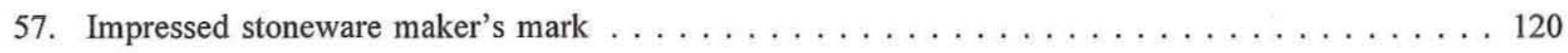

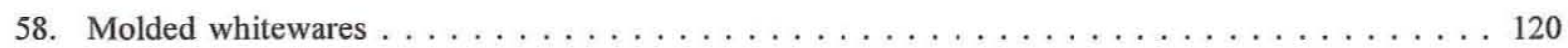

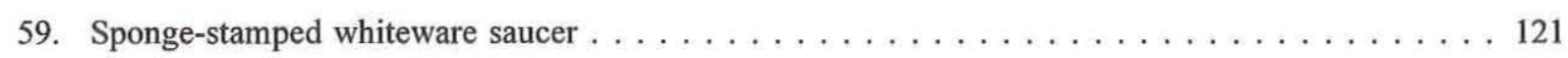

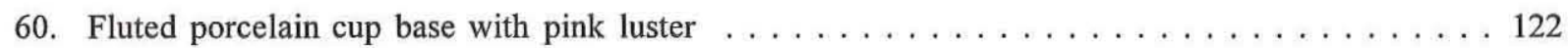

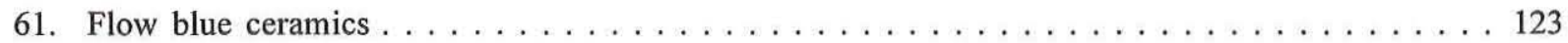

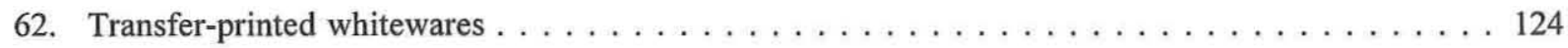

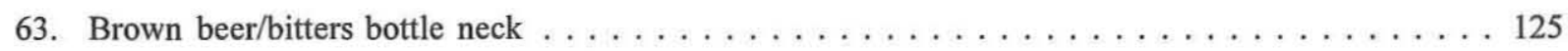

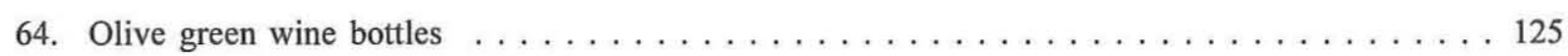

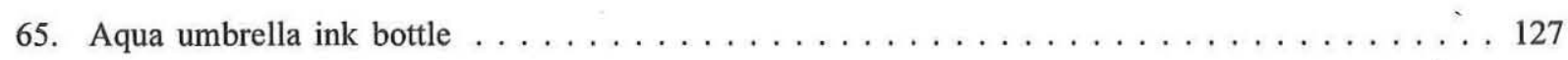

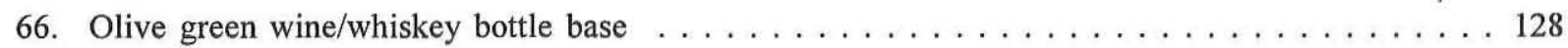

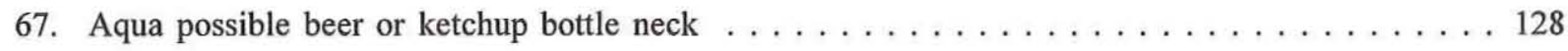

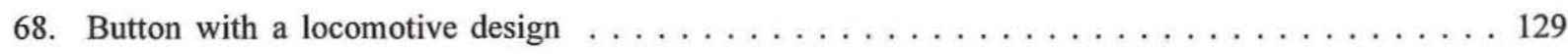

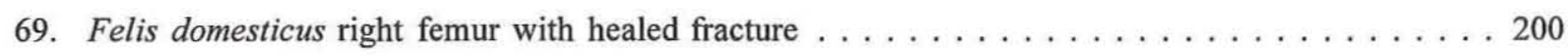




\section{LIST OF TABLES}

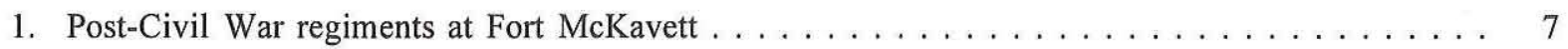

2. Conical bullets and round ball ammunition $\ldots \ldots \ldots \ldots \ldots \ldots \ldots \ldots \ldots \ldots \ldots \ldots \ldots \ldots \ldots$

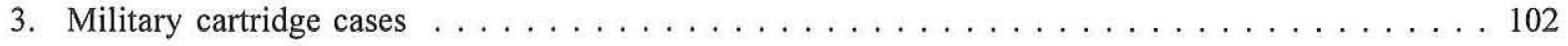

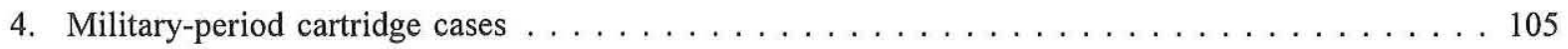

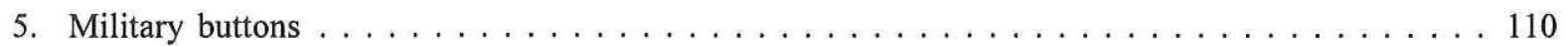

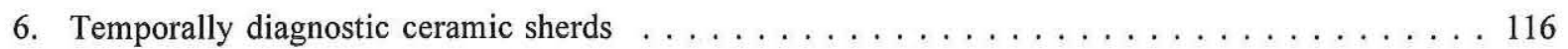

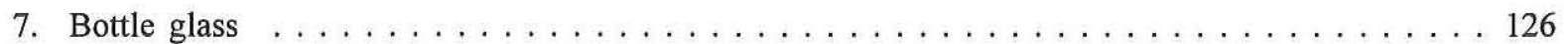

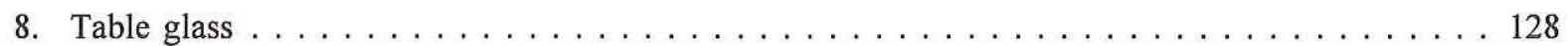

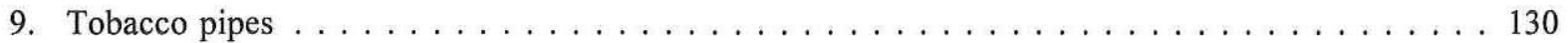

10. Comparison of South and Sprague classifications of the Fort McKavett artifacts $\ldots \ldots \ldots 160$

11. Comparison of collections using South's functional classes $\ldots \ldots \ldots \ldots \ldots \ldots \ldots$

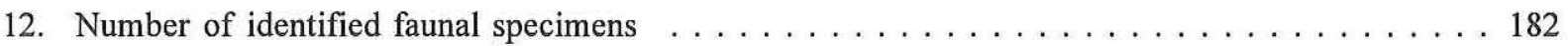

13. Minimum number of individuals for identified taxa $\ldots \ldots \ldots \ldots \ldots \ldots \ldots$

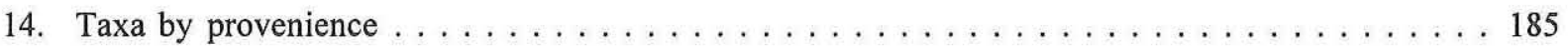

15. Selected and identified taxa by feature $\ldots \ldots \ldots \ldots \ldots \ldots \ldots \ldots \ldots \ldots$

16. Probable cultural taphonomic factors by feature $\ldots \ldots \ldots \ldots \ldots \ldots \ldots \ldots$

17. Cut marks on specimens from Officers' Quarters $4 \ldots \ldots \ldots \ldots 2$

18. Taxa, elements, meat cuts, and frequencies for mammals $\ldots \ldots \ldots \ldots \ldots \ldots \ldots$ 


\begin{abstract}
The U.S. Army occupations at Fort McKavett from 1853 until 1859 and from 1868 until 1883 were part of Texas's frontier defense. During the Civil War and from 1883 until the present, civilians have inhabited and used the fort buildings, creating the small town of Fort McKavett. The Texas Parks and Wildlife Department developed part of the town as a state historical park, restoring this property to its appearance during the second military occupation.

Archeological investigations at the park between 1978 and 1990 focused on recovering architectural data and artifacts to support restoration, stabilization, and interpretation of the military occupations. The archeological work varied from surface collection to large-scale excavations, the latter generally confined to Officers' Quarters 4, but the most common approach was limited testing in building foundations and suspected architectural features. Work took place in 16 structures. Most of the archeological work focused on officers' quarters, although a few enlisted mens' barracks and other buildings also were tested.

Relatively few temporally diagnostic artifacts were recovered in the vicinity of walls, fireplaces, and other architectural features, and only sparse military and military-period artifacts were found. The 372 military and military-period artifacts recovered from the post-1977 work at Fort McKavett and described in this report represent less than 0.01 percent of the total artifact assemblage and likely represent only a small proportion of the trash generated by the military occupations. Much of that trash probably was disposed of and possibly burned off-site or, if on-site, in pit latrines or other deep features not excavated during the 1978-1990 work. Military conduct, discipline, and policing may have functioned in keeping public spaces at this frontier military fort relatively litter free and thus artifact poor.
\end{abstract}




\section{ACKNOWLEDGMENTS}

So many people have contributed to this project at the Texas Parks and Wildlife Department over the years that it is impossible to thank them all. Art Black directed the field work, provided advice and references for artifact identification, assisted in coordination with the Texas Historical Commission, produced the artifact summary tables presented in Appendix D, and reviewed the report. George Kegley provided Appendixes B and $C$ providing background on and describing the Sprague code artifact classifications used. Under a separate contract with the Texas Parks and Wildlife Department, John Leffler researched and wrote the history of the civilian period provided in Chapter 2 .

Invaluable assistance by Texas Parks and Wildlife Department personnel was provided by Cindy Brandimarte, director of the Cultural Resources Program, who coordinated with the Texas Historical Commission and made it possible to include the civilian-period history and the explanation of the Sprague artifact classification system; Aina Dodge, director of the Archeology Laboratory, who organized the artifact recataloging and cheerfully handled requests for records searches; Eric Morley, Carlos Beceiro, Leigh Ann Garcia, and Karen Rumpf of the Archeology Laboratory, who recataloged and delivered the artifacts; and architect Dennis Cordes, who provided drawings. Former Archeology Laboratory crew members Cynthia Banks, Juliann Pool, and Marybeth Tomka performed much of the original artifact cataloging. Field crew members from 1978 until 1990 included Cynthia Banks, Cindy Brookshire, Maureen Cavanaugh, Leah Chadderton, Dan Crouch, Mike Davis, Tom Dureka, Eileen Goldborer, Rusty Greaves, Chris Jurgens, Steve Kotter, Vance Langley, Dino Lowrey, Jon McClenny, Mary McCready, Russell McNair, Mary Jane McReynolds, Ann Mesrobian, Juliann Pool, David Proctor, Margaret Rochelle, Susan Stiegelbauer, and Steve Zeman.

At Prewitt and Associates, Inc., Elton Prewitt and Ross Fields assisted in coordination with Texas Parks and Wildlife Department and the Texas Historical Commission. Doug Boyd reviewed the artifacts chapter. Karen Gardner directed the pulling of temporally diagnostic artifacts and identified the military-period glass and tobacco pipes. Many people provided space for the voluminous artifact collections and helped to move boxes. Kevin Stork organized the field notes and maps and performed the tedious task of extracting and cataloging the military and military-period artifacts. Kevin also identified many of the military artifacts. Brent Scott assisted in cataloging the military and military-period artifacts. Milton Bell took the artifact photographs, and Ellen Atha did the artifact drawings. Sandy Hannum directed the cartographic work and produced a few of the maps. Brian Wootan produced most of the maps and all of the photographic figures. Ross Fields reviewed the report and edited the plans and profiles for production. Linda Foster edited and produced the report. 


\section{INTRODUCTION ANID BACKGROUND}

\section{INTRODUCTION}

Fort McKavett was occupied by the military from 1853 until 1859 and from 1868 until 1883 as one of seven forts in Texas's western line of defense, established in the early 1850s. After military abandonment, civilians purchased the fort buildings, creating the small town of Fort McKavett in Menard County. The structures remained in private ownership until 1967, when two barracks buildings were donated to the Texas Parks and Wildlife Department (TPWD) and the process of development of the site as a state historical park began.

When TPWD began acquiring fort complex buildings in 1967, many of the structures were in ruins. By 1975,10 of the structures or areas reported here (Officers' Quarters 1, 4, 7, and 11; Barracks 2, 3, and 6; the Old Hospital; the commissary storehouse; and the highway right-of-way) were in ruins, and eight of the structures (Officers' Quarters 2, 3, 5, 6, 8, 9, and 10 and the schoolhouse) were still standing (Texas Parks and Wildlife Department 1975:107).

Original plans for adaptive use, stabilization, and reconstruction of buildings were reported in the preservation plan (Texas Parks and Wildlife Department 1975:103-105). The largely intact New Hospital was designated for adaptive use as the visitor center and park headquarters. Officers' Quarters 6, the headquarters, and Barracks 4 were to be restored and interpreted on the exterior and interior as 1875 structures complete with furnishings. The exterior of the schoolhouse had been restored in 1971, and the interior, although unrestored, was in good repair with minimal electrical service suitable for use as a group facility.

Development programs for six officers' quarters (Officers' Quarters 2, 3, 5, 8, 9, and 10) included exterior restoration and possible use of the interiors for adaptive purposes (e.g., storage). The modifications of these extant structures by civilian occupants were considered important in establishing historical continuity and in providing a visual association between the military Fort McKavett and the civilian town of Fort McKavett. It was recommended that these modified structures be restored only when routine maintenance of their present condition became no longer feasible and major repairs became necessary (Texas Parks and Wildlife Department 1975:104).

Approximately 12 military-period ruins, including the lime kilns, required structural stabilization, primarily involving masonry and mortar restoration. The goal of the stabilization program was to excavate archeologically and to restore and preserve existing wall heights and unique features of the structures. Archeological investigation was to precede building stabilization and to extend into areas without visible surface remains as more fort property was acquired and cleared of recent structures and debris (Texas Parks and Wildlife Department 1975:105).

This report is submitted in fulfillment of Texas Antiquities Committee Permit No. 178 issued to TPWD for archeological work at Fort McKavett State Historical Park (41MN2) between 1978 and 1990. The nature of the work varied from surface collection (some controlled by grid, as at the Old Hospital) to large-scale excavations, generally confined to the four rooms and east yard of Officers' Quarters 4, to the most common approachtesting in the vicinity of buildings and suspected architectural features. Most of the archeological work focused on officers' quarters, although a few enlisted mens' barracks and other specialized buildings also were tested. Nearly all of the 
investigations were oriented toward recovering architectural information to support reconstruction, stabilization, and interpretation efforts at this state park. Relatively few temporally diagnostic artifacts were recovered in the vicinity of walls, fireplaces, and other architectural features, and only sparse military and military-period artifacts were found.

This report consists of six chapters and four appendixes. The remainder of this chapter provides information on the site setting, a description of the site, and a summary of previous archeological investigations. Chapter 2 presents histories of the military and civilian periods of the site relevant to the archeological work reported here. The civilian history was written by John Leffler of Southwestern University, Georgetown, Texas, under a separate contract with TPWD. Chapter 3 details the research design, field methods, and analytical techniques. Exca-

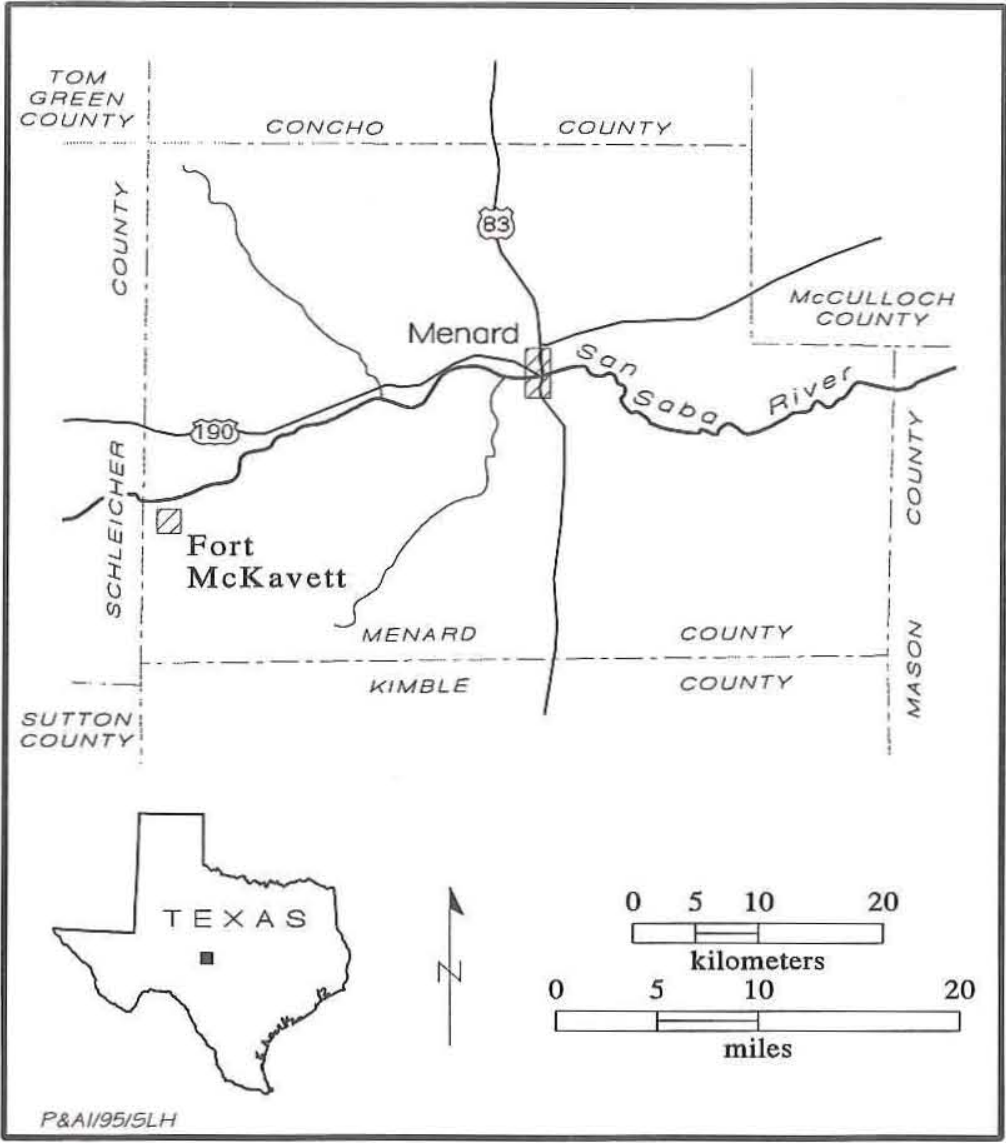

Figure 1. General location map.

vated or tested structures and features and their deposits are described in Chapter 4, and the military and military-period artifacts analyzed are described in Chapter 5. Concluding statements are given in Chapter 6. Appendix A is an inventory of the military and military-period artifacts analyzed for this report. Appendixes B and C by George Kegley discuss the functional classification of the Fort McKavett military and civilian artifacts and the Sprague code classification as modified by TPWD. Appendix D by Brian Shaffer is an analysis of the faunal materials recovered.

\section{BACKGROUND}

\section{Site Setting}

Fort McKavett sits atop a stony hill 2 miles from the headwaters of the San Saba River in westernmost Menard County (Figure 1). The San Saba River, in west-central Texas, originates with spring-fed creeks on the semiarid Edwards Plateau and flows eastward to the Colorado River, over 100 miles distant. The headwaters, on which Fort McKavett was established, are about 150 miles northwest of San Antonio at an elevation of more than 2,000 ft (Sullivan 1981:3; Texas Parks and Wildlife Department 1975:13).

The fort lies on a base of shallow very dark grayish brown Tarrant clay about 6 inches thick. The soils contain much lime and some limestone gravel. In some places, coarse limestone gravel, cobblestones, and flagstones are scattered over the surface. Below the 6 -inch surface is a $2-3$-inch layer composed of 85 percent limestone fragments, gravel, and stones and 15 percent sediments. The substratum is hard limestone that is fractured in most places in the upper few inches but may be soft, massive, and porous below (Texas Parks and Wildlife Department 1975:59).

A temperate warm, moist climate prevails year-round, with mild winters punctuated by occasional storms generated on the high plains to 
the northwest and with warm summers punctuated by common thunderstorms generated in the Gulf of Mexico to the southeast. The vegetation in the fort vicinity is primarily a semidesert grassland or open savannah. The potential climax vegetation is tall or mid grass understory with a brush overstory complex consisting of plateau oaks, shinnery oaks, junipers, and mesquite. Trees include pecan, black walnut, live oak, and willow, and an undergrowth of mesquite and chaparral, with a variety of cacti and wildflowers. The present-day vegetation still reflects overgrazing in the past. Before settlement, the terrestrial wildlife included deer, beaver, rabbit, prairie dog, bear, javelina, and cougar. Birds included wild turkey, swan, duck, quail, buzzard, and eagle. Taxa currently present include white-tailed deer, raccoon, gray fox, bobwhite quail, mourning dove, and wild turkey (Black and Ing 1980:9; Sullivan 1981:3; Texas Parks and Wildlife Department 1975:265).

\section{Site Description}

The 640-acre section of land upon which Fort McKavett is situated was patented by the State of Texas to M. A. Dooley in September of 1854 by virtue of a third class headright acquired in the Fisher-Miller Colony (Survey No. 304). The federal government originally leased the property from Dooley under a 20-year agreement. The Fort McKavett military reservation eventually totaled 2,300 acres (Sullivan 1981:10).

Fort McKavett remains one of the best-preserved posts of the Indian Wars period in Texas (Black and Ing 1980:2; Texas Parks and Wildlife Department 1975:13). With the exception of the two-story commanding officer's quarters, the fort structures, numbering 40 at one time, consisted of one-story buildings of roughly shaped limestone. The stones were wet laid, forming rough-surfaced walls from 18 to 24 inches thick that were sometimes plastered or whitewashed. After abandonment by the military, civilians purchased the fort buildings and grounds, and the town of Fort McKavett continued on the site. Civilians adapted some fort buildings for use as residences, thus insuring their longevity. Others, however, were neglected or robbed of materials to build fences or additions to existing structures. The town never became more than a small commercial center. With improved transportation and the town's by- pass by major highways, the population dwindled, and the town suffered the prolonged economic decline common to countless rural communities throughout Texas. By the mid 1960s, only a handful of people lived at Fort McKavett. In 1967, TPWD began acquiring the old fort buildings, many of which were in excellent repair through continuous usage, and established Fort McKavett State Historic Site, now Fort McKavett State Historical Park. The re-creation of the military atmosphere at the fort commemorates its position as an integral factor in the frontier defense system that opened West Texas to settlement (Sullivan 1981:58).

\section{Previous Archeological Investigations}

Controlled archeological investigations have taken place at Fort McKavett State Historical Park since the summer of 1969 , shortly after two barracks buildings were donated to TPWD. In 1969, Earl Green of Texas Tech University excavated Barracks 4, the eastern one-third of Barracks 3 , and parade ground features, such as the flagpole, guy wire anchors, and a nearby subterranean water reservoir which was part of an incomplete firefighting system, in search of archeological and architectural data pertinent to restoration and interpretation (Green 1969). In 1973, Emerson Pearson of the Texas Archeological Survey directed excavation and recording of extant architectural detail at the second bakery, Barracks 1 (test excavations only), and the headquarters building (Pearson and Carter 1973).

Excavations by TPWD began in 1974 and continued every year until 1980, with additional fieldwork in 1982, 1984, 1985, and 1990. The 1974 work involved an unsuccessful search for a blacksmith shop shown on an 1868 map, as well as preliminary clearing and testing of the quartermaster workshops building. The 1975 work included excavation of the central one-third of Barracks 3 and excavation and stabilization of the first bakery. In 1976 the excavation of the quartermaster workshops was completed and that structure stabilized, and stabilization of Barracks 1 was begun. During the 1977 season, Barracks 2 was excavated and the newly acquired western one-third of Barracks 3 was investigated. The 1974-1977 excavations were reported in Black and Ing (1980). Archeological work by TPWD from 1978 through 1990 is reported in this document. 


\section{HIISTORICAL BACKGIROUND}

\section{MILITARY}

The State of Texas's defense system began with the establishment of the Eighth Military Department of the Western Division by the United States War Department in 1848. The California gold strike of 1849 led to such accelerated westward immigration that greater protection along wagon roads to the west was necessary. When General Persifor F. Smith, military commander in Texas, inspected the frontier in late 1851, he located the western line of defense beginning at Fort Belknap on the upper Brazos River and continuing southwest to Fort Clark on Las Moras Creek above the Rio Grande, between Del Rio and Fort Duncan at Eagle Pass (Figure 2). Fort McKavett was in the southern half of that line of defense. A location west of the Fisher-Miller Grant and near the upper road from San Antonio to El Paso was chosen to protect settlements from Indian raids and to protect travelers and supplies. In May of 1853, the position of the post was established at the junction of the San Saba River and a spring-fed creek. The post, first referred to as the camp near Fort Mason and as Camp San Saba, officially acquired the name Fort McKavett in 1853 in honor of Captain Henry McKavett, an officer of the 8th Infantry killed in the Battle of Monterrey during the Mexican War (Texas Parks and Wildlife Department 1975:11, 15).

Construction of permanent buildings began immediately upon occupation of the site. Enlisted men provided the construction labor in the absence of a civilian work force. Each company was responsible for the erection of its own quarters, including those of the officers, and the entire garrison participated in the construction of general- use buildings (Sullivan 1981:10). The buildings were placed around the perimeter of a $400-\mathrm{x}-400-\mathrm{ft}$ main parade ground. A letter written by commanding officer Colonel E. B. Alexander in August of 1853 described the buildings as plain rectangular houses of stone, except for the log storehouse, all of which were covered with oak shingles. The stone was quarried locally, and wood-primarily pecan and oak - was cut near the post. During the first year, the buildings were without floors, glass windows, or doors, but these materials later were freighted 100 miles from Fredericksburg (Sullivan 1981:10). Temporary frame and picket structures provided the remainder of the housing. Later that same month, Colonel W. G. Freeman, in the first official inspection of the post, noted that construction and fatigue duty took most of the men and time available, and the difficulty in acquiring proper pine or cypress lumber to finish the buildings meant that holes had to be bored into the warped local pecan boards so that hand-wrought nails could be driven through them (Texas Parks and Wildlife Department 1975:15-16).

At the post's second official inspection by Colonel J. K. F. Mansfield in July of 1856 , he reported the completion of the buildings previously under construction. At that time, the fort complex consisted of 21 permanent structures, including officers' quarters, barracks, adjutant's office, commissary, and hospital (Texas Parks and Wildlife Department 1975:19).

In May of 1857, Lieutenant S. B. Holabird, Fort McKavett quartermaster, made the last and most complete report of the fort before its abandonment in 1859. Five sets of stone-and-shingle officers' quarters (Officers' Quarters 2-6) stood on 


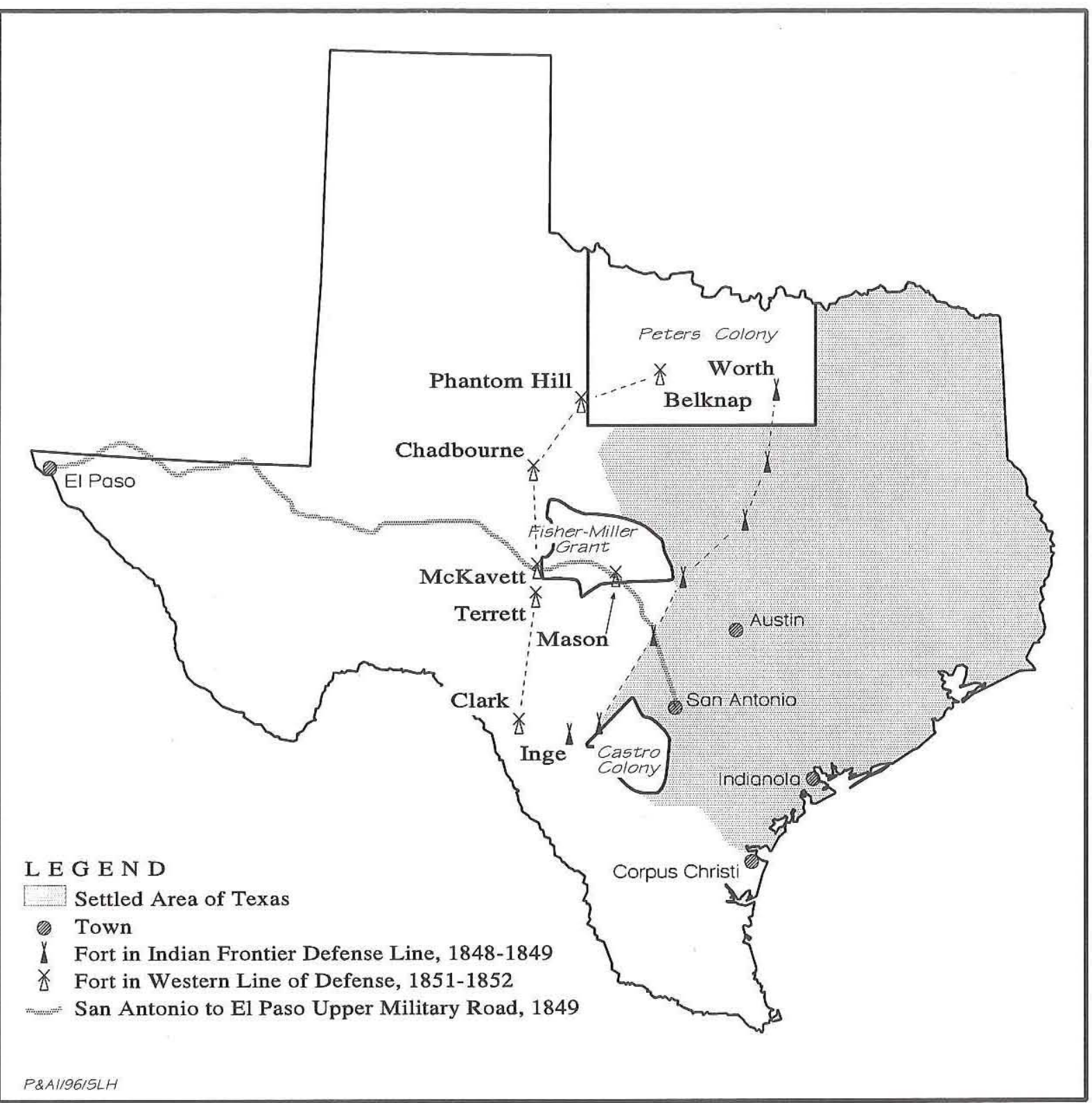

Figure 2. Military forts and frontier settlement in the mid nineteenth century.

the south side of the parade ground, and officers also occupied two other stone buildings west of the parade ground (Officers' Quarters 1 being one of the these). Holabird reported that company quarters or barracks were completed and occupied, consisting of an orderly room at one end separated from the main room by a stone partition wall and with two stone buildings in the rear serving as company mess rooms and kitchens (Texas Parks and Wildlife Department 1975:23).

The post was not a self-sufficient community.
All supplies except lumber, fuel, and hay had to be sent from the main supply depot in San Antonio, 150 miles distant. Fuel had become scarce in 1857. Forage was furnished by contract, with some of it hauled from Fredericksburg. Contract transportation was a problem in the 1850 s because of the high price per pound and also the supplies and manpower needed for escorts. Fort McKavett was 50 miles southwest of Fort Mason, 100 miles south of Fort Chadbourne, and 28 miles north of Fort Terrett. Good roads existed most of the way 
to Fort Mason from San Antonio and from Fort McKavett to Fort Chadbourne except for a few rocky miles between Fort McKavett and Kickapoo Creek (Texas Parks and Wildlife Department 1975:23).

Fewer than 10,000 men constituted the United States Army from 1846 to 1860 , and much of this under-strength army consisted of infantry instead of cavalry. The troops' lack of mobility made it difficult to follow orders requesting regular scouting patrols be made from the forts. It was not until after the Civil War that the use of cavalry on the frontier reached its peak. The three regiments that garrisoned the fort during the $1850 \mathrm{~s}$ were the 8th Infantry, with five companies, from 1853 until 1854; the 2nd Dragoons, with two companies, from 1854 until 1855; and the 1st Infantry, with two companies, from 1855 until 1859. Each company included 30 to 40 men and 1 or 2 officers (Texas Parks and Wildlife Department 1975:25).

With the growing self-sufficiency of the settlers and the decrease in danger from Indians in the late $1850 \mathrm{~s}$, the fort was abandoned in March of 1859 and reverted to its citizen owner. Fewer than a dozen families lived on the post premises, and the unoccupied buildings were used as barns, cowpens, and pigpens (Texas Parks and Wildlife Department 1975:25).

An upsurge in Indian hostilities after the Civil War necessitated the re-establishment of the post. A frontier defense act was passed by the Texas legislature in 1866 , and the following year the federal government ordered that the frontier forts be readied to receive troops. Fort McKavett was reopened officially on April 1, 1868, and the complete force totaled two companies of the 4th Cavalry and three companies of the 35th Infantry. Post-Civil War regiments serving at Fort McKavett are listed in Table 1. When the troops returned to Fort McKavett, they found the buildings in a state of decay with walls fallen in and roofs gone. Surgeon N. D. Middleton said that the post was one mass of ruins, with only the commanding officer's quarters being habitable, and the whole command was forced to go under canvas (Texas Parks and Wildlife Department 1975:27).

When commanding officer Major G. A. Gordon began to rebuild, he sent details south, in the direction of Fort Terrett, to cut cedar pickets to

\begin{tabular}{|l|l|}
\hline \multicolumn{2}{|c|}{ POST-CIVIL WAR REGIMENTS } \\
AT FORT McKAVETT
\end{tabular}

build temporary structures. Lieutenant Boehm reported that he was cutting at the rate of 200 pickets a day so that in 3 weeks he would have enough to construct all the necessary buildings. The post surgeon commented that the old walls were being rebuilt and new roofs secured in order to have the buildings ready for the men by December of 1868. "The barracks buildings should have been moved altogether and more suitable buildings built in their place. This was decided against in order to get the troops under cover before winter. Several of the officers' quarters are used but they are entirely unsuitable being badly in need of repair" (Texas Parks and Wildlife Department 1975:27).

The fort buildings which remain today are primarily the results of the rebuilding program that took place during the second military occupation under Colonel Ranald S. Mackenzie's command (Figure 3). In most instances, the buildings were rebuilt on the earlier foundations instead of being relocated elsewhere, as was noted for the barracks and officers' quarters, above. In March of 1869, when Mackenzie and two companies of the 9th Cavalry and two companies of the 41st Infantry arrived at the fort, very little work had been done on the buildings because of the lack of mechanics and the extreme slowness with which supplies arrived. Renovation of barracks, company kitchens, sinks, and all outbuildings took place, and officers' quarters were rebuilt with new floors, doors, windows, and roofs (Texas Parks and Wildlife Department 1975:27, 41-42). 


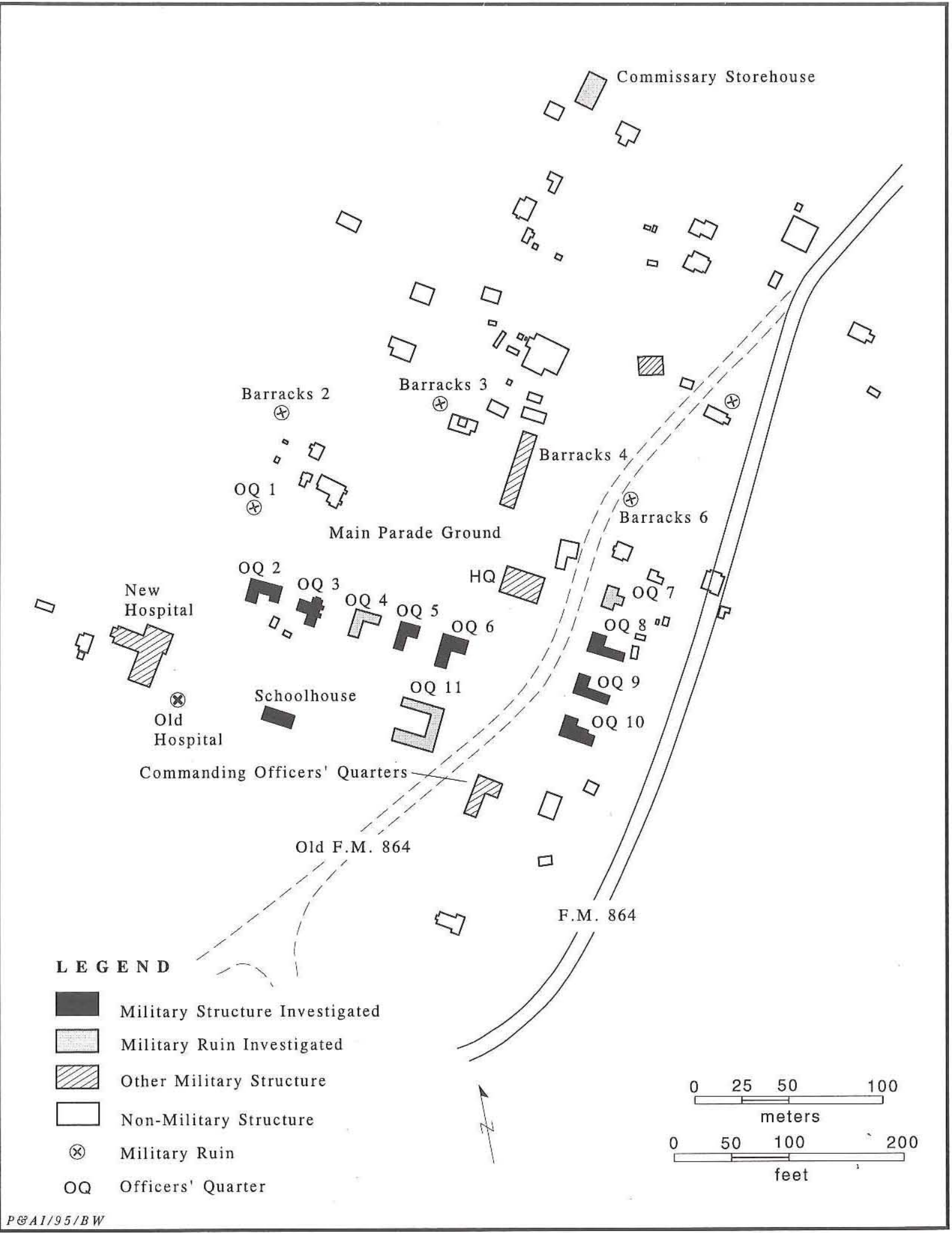

Figure 3. Site map. 
The schoolhouse was most likely the last major construction activity undertaken by the military. The need for a schoolhouse was noted as early as March of 1873 , when the commanding officer reported that 20 children at the post should be in school, not considering enlisted men who also should be taught. By November 1878, a post school had opened. No new buildings are indicated after this date, although minor improvements and alterations of the buildings took place throughout the 1870s. Accommodations were crowded and never completely suitable. The married soldiers lived in picket huts and canvas tents, which were inconvenient and in bad condition. Very small, poorly constructed fireplaces heated most of the buildings, although the quartermaster provided some stoves for the officers' quarters as they became available (Texas Parks and Wildlife Department 1975:31).

Indian campaigns became less frequent in the late 1870 s, and the Indian threat to west-central Texas largely had disappeared by 1880 . Shops, residences, and a chapel were built on the site. In October of 1880 , the post commander was told that the post would not be occupied much longer and he should attempt only necessary repairs. By November of 1882 , the garrison consisted of 3 officers and 29 men of the 16th Infantry. Federal troops abandoned the fort on June 30,1883 , and a special inventory recorded 40 buildings. The quartermaster stated that no changes or alterations had been made during the past year, and repairs had been confined to the replacement of door locks and hinges and minor maintenance. The buildings had received little repair for several years but were reported to be in good habitable condition and were abandoned with their attachments and fixtures in place. The buildings, except for the structures built since 1879 , which were disposed of at a public sale, reverted to the civilian owner of the site (Texas Parks and Wildlife Department 1975:39).

Edith Black Winslow, daughter of rancher William Black, arrived at the town of Fort McKavett in 1884 and later wrote about her memories. Her father bought some of the barracks roofs to use on their ranch house. She said, "We always held him responsible for the downfall of the fort, for the buildings soon tumbled to the ground, and are now [1950] piles of rubble stones" (Texas Parks and Wildlife Department 1975:41). A 1961 report remarked that only 17 fort buildings were standing. In 1970 the town of Fort McKavett had 103 inhabitants housed mainly in the old fort buildings and in structures erected from some of the stones of the fort buildings. Recently erected frame buildings were dispersed among the ruins (see Figure 3). Rapid deterioration of the fort buildings had occurred since military abandonment in 1883, when 40 structures existed (Texas Parks and Wildlife Department 1975:41).

\section{CIVILIAN}

The U.S. Army post at Fort McKavett was decommissioned on June 30, 1883; soon afterward, the town of Fort McKavett (sometimes also known simply as "McKavett") was established amidst the structures left behind when the soldiers left. The town grew slowly, and in 1900 the community surrounding Fort McKavett was possibly the largest in Menard County. Economics, politics, and geography all worked together to stunt Fort McKavett's growth, however, and by 1910 the town had been permanently eclipsed by Menard, the county seat. Nevertheless, the community remained a significant social center for the surrounding population, even as the town's decline actually helped to enhance its growing reputation as a haunting remnant of the past. During the late 1960 s, the State of Texas acquired parts of the old army post and began to create what would become Fort McKavett State Historical Park. By the late 1970 s, the state had acquired more than 40 parcels of land - almost all of the town - and efforts to restore the old fort were under way. Visitors to Fort McKavett State Historical Park are struck by the quiet isolation of the place and find it easy to imagine what the fort might have been like in the 1870 s. More difficult to conjure is the lost town of Fort McKavett, which occupied the site for almost a century before the park was created.

\section{The Origins of the Fort McKavett Community}

What is now Menard County was included in the Fisher-Miller Land Grant of 1842, which was intended to encourage settlement in the area, but few settlers, if any, moved into the region until after Texas was annexed by the United States. After 1852, when the United States Army 
established Camp San Saba (soon called Fort McKavett) near the headwaters of the San Saba River, settlement in the area accelerated somewhat, and in 1858 the Texas state legislature created Menard County from lands previously assigned to Bexar County (Smyrl 1991b:2). In the summer of 1859 , not long after the U.S. Army first abandoned Fort McKavett, ox-drawn wagons carried Lucy Robinson (Mrs. P. D. Robinson), her daughter Lucy Ann, and her grown sons Robert and Joshua and their families into the Menard County area. Mrs. Robinson ultimately purchased a number of tracts in what are now Menard, McCulloch, and San Saba Counties; one parcel included the site of the abandoned fort. The Robinson family moved into the headquarters building. After Lucy and Joshua D. died of cholera during a trip to San Antonio in 1866, Robert Robinson and other members of the family remained there until 1868 , when the army returned (Menard County Historical Society 1982:240-241; Streigler 1962:1).

Other families in the area by this time were the Caseys, the Schellenbergers, the McDougals, and the Champies (Menard County Historical Society 1981:223-224; Striegler 1962:2). Charles Champie is an early example of how the army's presence itself augmented settlement in the vicinity. Born in 1833 of French Canadian parents, Champie had run away from home and enlisted in the army in New York; in 1852 he was posted to Fort McKavett. After being caught stealing a watermelon from the Schellenberger garden, he met Mary Elisabeth Schellenberger; in 1859 they were married, and the couple stayed in the area after the army abandoned the fort (Menard County Historical Society 1982:224).

As the threat of Indian attacks increased after the troop withdrawal, a number of settlers from the surrounding area moved into the fort with the Robinsons, and buildings not housing humans were used as barns or to hold cows and pigs. Although Confederate forces sometimes patrolled the area, during and just after the Civil War Indian raiding parties seemed to move through the region with virtual impunity. In August 1866, a group of several hundred Kickapoos drove off more than 15,000 head of cattle from the San Saba Valley; William McDougal, a rancher who lived about a mile south of the fort, was killed during the raid, and his stepdaughter, Clara Schellenberger, was lanced but survived (Pierce 1966:150; Sullivan
1981:24). In response, the men living in Fort McKavett formed an organization of "minutemen" to deal with the threat (Sullivan 1981:25). Despite these dangerous conditions, another community, called Mud Flats, also seems to have grown at about this time around a trading post about 3 miles from Fort McKavett on the other side of the San Saba. Mud Flats apparently had a school, which may have been attended by the children living in and around the old fort at the time (Menard County Historical Society 1982:79; Pierce 1966:66). Menard County residents asked the state for more help against the Indian threat, but to no avail; and after residents failed in an 1866 attempt to organize the county, the area was placed under the jurisdiction of Mason County for judicial purposes (Smyrl 1991b:2; Sullivan 1981:25-26).

In April 1868, the army reoccupied Fort McKavett, renting the land from the estate of Joshua D. Robinson (Bierschwale 1966:85; Sullivan 1981:27, 30-31). Though of course local residents welcomed the protection the fort provided, many of them also embraced the economic opportunities created by the army's return. Locals gathered wood for the fort's fuel, hay for its animals, and grew crops and sold cattle to feed the soldiers of the fort. Charles Champie's family, for example, slaughtered a "beeve" every day for the post's commissary, and also grew fruit and vegetables for soldier consumption (Bierschwale 1966:54; Menard County Historical Society 1982:286, 224). Mud Flats disappeared as its inhabitants apparently moved to the vicinity of Fort McKavett (Pierce 1966:66).

The possibilities for profit afforded by the reactivation of the fort also attracted a wide variety of people from outside the area, and soon a civilian community grew on the north bank on the San Saba across the river from the fort. The town's population was a rich mix of different ethnic backgrounds and races. William Lehne, a German immigrant, had lived with his wife Theresa and their three children in Fredericksburg before moving about 1870 to the little community growing across the river from Fort McKavett. He established a combination store and saloon there (Figure 4a) and also did some freighting (Lehne 1995; Menard County Historical Society 1982:387, 388). His store may have helped to form the nucleus of the new community, for according to one source the new town was first chartered as 


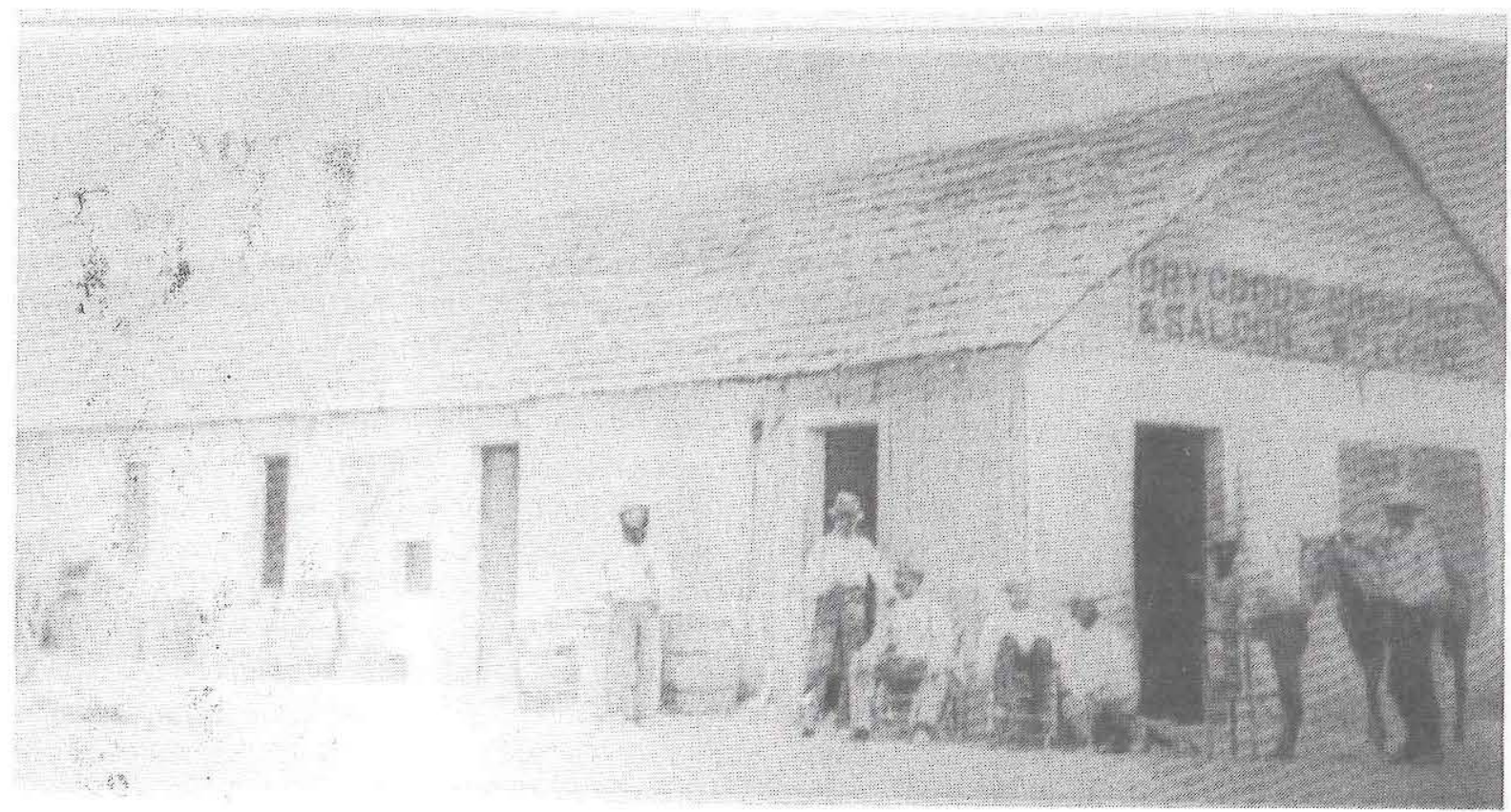

a

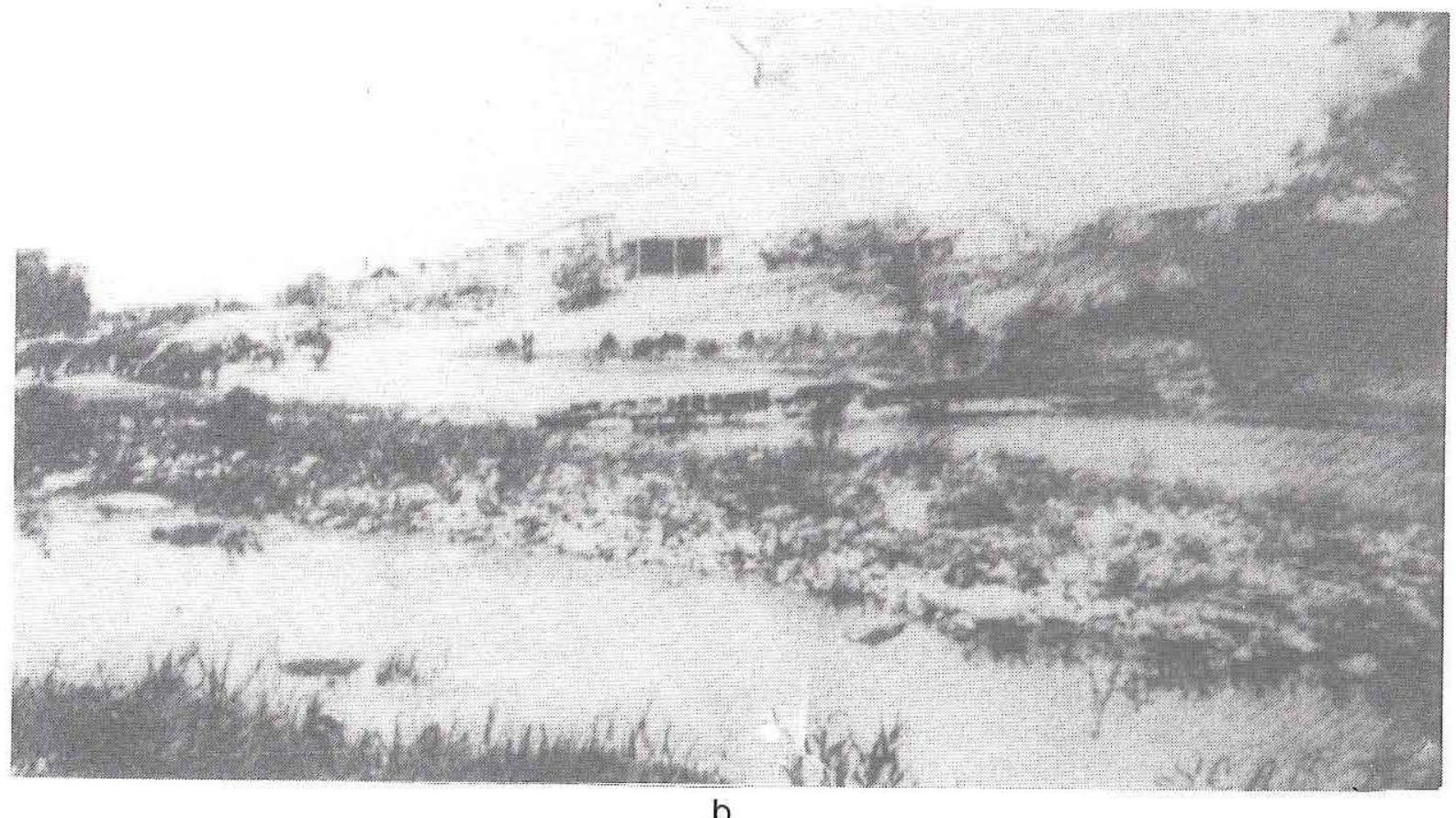

b

Figure 4. "Scabtown" in 1876. (a) William Lehne Store; William is second from left; (b) overview. Photos courtesy of Menardville Museum, Menard, Texas. 
Lehnesburg (Menard County Historical Society 1982:35). Thomas and Bridgett (Feeney) Lee were Irish immigrants who had met and married in New York City. Tom, a master mason, worked on military construction projects at Fort Davis and Fort Mason before moving to Fort McKavett with his wife and children. Once there, he also became involved in freighting ventures and disappeared on a trip to Colorado City. Bridgett opened a hotel and boarding house in the emerging town, and operated a goat milk business (Anonymous n.d.; Menard County Historical Society 1982:387). John Flutsch, born in Switzerland in 1833, entered the United States in 1854; he lived in Erath County for at least a year before he moved to the McKavett area in 1871 with a contract to butcher meat for the army (Menard County Historical Society 1982:286; U.S. Census Manuscript Population Schedule, Menard County [USCMC], 1900). During the early 1870 s, when most of the troops stationed at the fort were African-Americans, many of the civilians living across the river were black, and an African-American served as the local peace officer (Sullivan 1981:39). Fritz Mayer, another entrepreneur, moved with his wife and family to the new community from San Antonio and opened a "mercantile emporium" (Menard County Historical Society 1982:37).

A gambling house and "establishments of pleasure" appeared for the entertainment of the fort's officers and soldiers, and the community came to be called "Scabtown," though it was also known as "McKavett" (Pierce 1966:66-67, 70-71; Smyrl 1991a:1; Sullivan 1981:39). Rows of tents and shacks were set up in the town, though moresubstantial structures also were built (Figure $4 b$ ) (Menard County Historical Society 1982:387; Pierce 1966:67; Sullivan 1981:51). Drunken violence was not uncommon in Scabtown, and since the settlement attracted a number of horse thieves and other criminals, the Texas Rangers became familiar with the place; on occasion it was "depopulated" after Ranger raids (Pierce 1966:67-69; Sullivan 1981:39-41). That the town also had a "Baptizing Hole" is an indication that some members of the town were at least occasionally interested in the Lord's work. According to one source, the hole was located on the San Saba just below "Scabtown," where Spring Branch joins the river (Anonymous n.d.).

Local boosters pushed for the town to become the county seat when Menard County was organized in 1871, and when Menardville (later called simply Menard) won the honor instead, they worked to have the decision overturned. Believing that their community could become a "thriving metropolis," McKavett boosters in the western part of the county apparently hatched a plan to enlarge Menard County, thus placing their community closer to the center of the county (Pierce 1966:70; Sullivan 1981:43). Citizens of Menardville caught wind of the scheme, however, and launched a preemptive strike against their rivals. In May 1876, a petition bearing the signatures of 70 county residents was sent to the state legislature, complaining that "an effort is being or will be made to induce your honorable bodies to pass a bill providing for the removal of the county seat of Menard County from Menardville to a point near Fort McKavett." "We also have understood," the petitioners continued, "that interested parties will ask the legislature to annex thirty miles of Bexar territory in which there is probably not a single settler, merely for the purpose of placing the geographical center near McKavett." Any such change, the petitioners argued, would only "inure to the benefit of a few, and to the detriment of the people of the county." Since the petition carried the names of most of the county's property owners, aside from those living around McKavett, the McKavett scheme was effectively put to rest, and Menardville remained the county seat (Pierce 1966:70-71; Sullivan 1981:44). Although the plan to grab the county seat ultimately failed, the episode demonstrates that at least some of the civilians in and around Fort McKavett thought of their community as potentially something more than a "parasite town." Those responsible for the plan were ambitious and fairly shrewd, and they were thinking about the future.

\section{The Development of the Town of Fort McKavett, 1883-1900}

As Indian activity in the region decreased during the late $1870 \mathrm{~s}$, the number of soldiers garrisoned at Fort McKavett also shrank. By the end of 1879, the last of the black "Buffalo Soldiers" had been transferred from the fort, and by December 1880, it was common knowledge that the fort would soon be closed (Sullivan 1981:47, 54). The abandonment of the fort seemed sure to 
be a serious blow to the local economy. Although Menard County's population had doubled between 1870 and 1880 , that year only 1,236 people lived in the entire county, and only 36 ranches or farms had been established there (Smyrl 1991c [hereafter cited as U.S. Census] 1870,1880 ). Certainly the prospects might have seemed rather dim for those contemplating staying after the army left. On the other hand, the McKavett site was attractively situated near the headwaters of one of the few rivers in the region. To some, the area might have seemed on the verge of rapid development, and good ranchland was still available in the surrounding countryside. Although many of the former civilian inhabitants of the fort and "Scabtown" left the area after the fort was ultimately closed on June 30, 1883 (Sullivan 1981:57), a number of others stayed on. The "parasite" community continued to live, and even briefly flourished, independent of its former host.

Possibly one of the inducements for some of those who remained behind was the old fort itself. The army left behind 40 well-constructed buildings which, according to the War Department's final inventory, were "in good habitable condition, and . . . left with their attachments, fixtures, and all belonging under the law to the realty, just as moved out of by the troops" (Bierschwale 1966: 84). Although a number of "Scabtown" residents moved into the fort buildings some time after the army left, it is not clear exactly how quickly they did so, or under what terms, if any. Although "squatters" may have quickly occupied some of the buildings, the presence of Dr. Robert Robinson might have prevented this from happening. Eliza Jane Robinson, the owner of the Fort McKavett site, was the widow of Dr. Robinson's brother, Joshua (Bierschwale 1966:85; Streigler 1962). Dr. Robinson moved into the stone hospital building soon after the army left, partly perhaps to guard Eliza Robinson's interest in the buildings.

Fort McKavett was described in the 1884 Texas State Gazetteer as "a post office in Menard County, . . 138 miles west of Burnet, the nearest railroad station and banking point" with a population of about 40 . Only three businesses were listed there that year: a saloon owned by J. S. Layton \& Co., a general store operated by F. Mayer, and another general store run by "Samuel Wallack [sic]," the "post trader" (Texas State Gazetteer 1884). This laconic description, almost surely written in 1883 when Sam Wallick was still, as he had been for years, the post sutler at Fort McKavett, can probably best be understood as a snapshot of the Fort McKavett community during the period of transition from military presence to civilian ownership. It can also be seen as a portrait of the central elements of the community that would soon develop. Within a few years after the army left, Eliza Robinson sold a number of the buildings and tracts from the old fort, however, and the town began to expand. Dr. Robinson was legally empowered to conduct the sales for Mrs. Robinson, who by this time was remarried and living in Newton, Massachusetts (Bierschwale 1966:85; Menard County Historical Society 1982:141; Sullivan 1981:57, 52).

A brief survey of some of the real estate transactions conducted during the 1880 s concerning parcels on the site of the abandoned fort reveals distinct continuities between the civilian community in the area before and after the army left. Combined with various accounts and descriptions of the early town, these can also help to sketch out a map of the early town and its inhabitants (although many of the buildings have not been investigated archeologically and are not discussed in this report). Samuel Wallick, who had been Fort McKavett's post sutler, bought three tracts from Eliza Robinson, including a 2.5-acre tract he purchased in 1885 which encompassed the Quartermaster's Store Building. Also in 1885, Fritz Mayer, once the owner of Scabtown's "emporium," bought a 5-acre tract which included the old corral and commissary storehouse at the north end of the fort (see Figure 3); about the same time, he purchased a half-interest in "the Old Guard House, and adjacent buildings." In 1888, Theresa Lehne, the widow of William Lehne, who had established one of the first stores in Scabtown, purchased 4 acres from Eliza Robinson. Robert Flutsch, son of John Flutsch, purchased a building described as "the Old Band Quarters" on the secondary parade ground in the vicinity of the Headquarters Building in 1888. Jonathon Miles, whose family had lived in Scabtown during the army days, acquired the Headquarters Building, which by the late $1880 \mathrm{~s}$ had become the "Treewick" or "Traewick" Hotel; Bridgett Lee, the Irish widow who had established a boarding house in Scabtown, purchased the "Traewick Hotel" from Miles in 1889. Dr. Robertson continued to live in the stone Hospital 
Building (see New Hospital on Figure 3) during most of this period (Anonymous n.d.:2; Real estate contract between Ester Stodart, Maria Stodart, and L. L. Ball, December 5, 1908 [hereafter cited as Ball Deed 1908], in Chain of Title Folder, Acquisitions Files, Texas Parks and Wildlife Department [CTFAF]). Others associated with the old fort and Scabtown did not move onto the premises of the fort, but settled on land in the surrounding area and established ranches. Henry Murr and his brother Adam (or "Ad"), for example, had been born in New Holland, Pennsylvania. Both joined the army as young men, both had been posted at Fort McKavett, and when they were discharged in 1882 , both remained in the area; Henry and his wife Jane settled on a ranch near Fort McKavett, and a number of their descendants lived in and around the town in ensuing years (Menard County Historical Society 1981:545-456). William Lehne, who had owned a store in Scabtown, died in 1877. After the army left, his widow, Therese, established a home at Fort McKavett in the northern corner of the settlement; his sons hired out to various ranchers in the vicinity. One of his sons, Louis H., at one point opened a saloon in McKavett and later ran a grocery store there; another son, George, established a ranch nearby (Lehne 1995; Menard County Historical Society 1982:387-389).

The appearance of Fort McKavett began to change soon after the army left, partly because of the arrival of the legendary ranchman "Colonel" William Leslie Black. Born in New Orleans in 1843, Black was a Confederate veteran who had been seriously injured at the Battle of Shiloh; later during the war, while in the Confederate navy, he was taken prisoner and jailed at Fort Alcatraz in San Francisco Bay. After the war, he eventually moved to New York City where he helped to found the New York Cotton Exchange and accumulated a sizable fortune. In 1875 he moved to St. Louis and soon became interested in wool, which he believed would be more profitable than cotton. In 1876 Black bought about 30,000 acres of land in eastern Schleicher County, near Fort McKavett, from Robert Robinson and became an absentee rancher. During his yearly visits to his holdings, he developed a yearning to move to the area, but his wife Camilla, used to the comforts and refinements of city life, had strong reservations. Black finally convinced her to move to Texas with seven children, partly by promising to take all of their furniture with them (Carlson 1982:121-124; Menard County Historical Society 1982:185-187). In 1884 the Blacks arrived at Fort McKavett with a train of seven wagons, and rented the hospital building from Robert Robinson for the year or so it took to construct their new house on the ranch. To build his house and develop his ranch, Black apparently paid the Robinson family for the salvage rights to a number of buildings. The roof and main beam of his home were taken from the stone barracks on the northeastern edge of the parade ground, and roofs were possibly taken from other stone buildings, too; without protection from the elements, the roofless structures "soon tumbled to the ground" (Garza 1995; Menard County Historical Society 1982:186-187; Winslow 1950:24). According to some accounts, Black also bought and razed plank barracks and used the materials for ranch buildings; one building was reportedly cut in half and moved to his ranch for the same purpose (Anonymous n.d.). Black cannibalized the fort for his own purposes, but his energetic activities no doubt provided work and income for a number of local residents during the crucial period of transition just after the army abandoned the site.

During the 1880 s, the isolated Fort McKavett settlement maintained its previous reputation as a refuge and resort for criminals. There were two saloons in the town (including Fritz Mayer's), and, as one writer put it, "cowboys and daredevils made things exceedingly lively when they came to town" (Hunter 1924:18; Meador n.d.a:1). John Vaden, a notorious outlaw who had killed several men, lived in or around the town during this period, and at one time owned a saloon there. John Warren Hunter, who later became known as the founder of Frontier Times magazine, was in the town in 1886 when Vaden was killed there by Ben Daniels, the bartender at Fritz Mayer's, after a day of drunken viciousness (Hunter 1924:16-18; Sullivan 1981: 65). The justice of the peace (or "alcalde," as he was also known) at Fort McKavett during the 1880 s was John Flutsch, the Swiss immigrant who had moved to Scabtown with a butchering contract. Flutsch's no-nonsense style of justice sometimes reflected the hostility, or lack of sympathy, felt by many Texans against Mexican nationals and Mexican-Americans at the time. One writer later compared him to Judge Roy Bean: 
He knew little of the law; a lawyer he despised, and the attorney who appeared in his court with a stack of law books was regarded with contempt. Justice and equity he strove to administer, and if in certain instances his decrees seemed harsh and unreasonable, he believed the result would prove beneficial to the community [Cunningham 1934; Hunter 1924; Meador n.d.b:6].

By 1889 Fort McKavett had been more-orless pacified and had begun to grow beyond the small circle defined by the original stores and saloons operated by Mayer and Wallick. The community was connected to the outside world by telegraph and telephone service available at Fritz Mayer's store (Figure 5a) and by the San AngeloMcKavett Stage Line, which offered daily service between the two towns except on Sunday. McKavett now also had a weekly newspaper, the Fort McKavett Breeze, and a hotel called the Traweek House (also known as Treewick or Traewick Hotel), managed by Mrs. M. A. Traweek, which advertised "neat and clean beds" and "firstclass" accommodations (Figure $5 b$ ). John C. Regenier, born in Iowa, had by this time settled into the town with his Irish-born wife and established a blacksmith shop; he also worked as a wheelwright and carpenter. In August 1889, Regenier and another carpenter, H. J. Kviel, completed work on a new saloon building owned by Fritz Mayer. Meanwhile, Johnson's Saloon advertised its proximity to a feed and camp yard, clearly a competitive edge for attracting travelers passing through town or ranchers coming in to shop. G. H. Parker had established a well-drilling business in town by 1889 , and McKavett was also served by a physician, Dr. Harry G. Jones, who had moved to the area from Philadelphia hoping that the clear air would help alleviate his lung problems. As noted above, Bridgett Lee bought the Traewick Hotel in late 1889, and soon ran it as the McKavett Hotel. By 1890, a broom and mattress factory had also been established in Fort McKavett by T. W. Henning, and an estimated 80 people lived in the town (Fort McKavett Breeze, 3 August 1889, 10 August 1889; Menard County Historical Society 1982:341-342; Texas State Gazetteer 1890-1891; USCMC 1900).
Social institutions also developed in the growing village to serve both the immediate community and the people living on surrounding ranches and farms. The school established during the days of army occupation may have continued to operate without interruption after the shift to civilian control; in 1886, when John Warren Hunter began teaching there, the school had 54 pupils (Hunter 1954:201). It is not clear, however (despite a longstanding tradition), whether classes were conducted continuously in the old stone school building (the schoolhouse on Figure 3) during this period. The building was purchased from Eliza Robinson in 1885 by James Callan and was not sold to the county until 1895; according to a 1940 inventory of Menard County schools, the building had only been used as a school since about 1915 ("Facts Revealed from Record Search" in Schoolhouse Tract File, CTFAF; Powell 1940: 35; Sullivan 1981:65). An Episcopal congregation had also been organized in the Fort McKavett community during the $1880 \mathrm{~s}$. The first meeting was held in Sam Wallick's house, and services were conducted in the schoolhouse, in the New Hospital, or in the hotel. By 1890, Methodist and Baptist congregations had also been organized (Menard County Historical Society 1982:77-78; Texas State Gazetteer 1890-1891; Williamson 1995).

The Fort McKavett Breeze was published by William Columbus Redman, who had established another paper, the Menardville Monitor, in 1888 before moving his printing equipment to Fort McKavett (Webb 1952:II:453-454). The paper printed mostly boilerplate agricultural advice and human interest stories, many intended for female readers. Fully half of the front page of the paper's August 3,1889, edition, for example, was devoted to an article entitled "Summer Gowns-Picturesque Costumes Worn By Dressy Women at Divers[e] Pleasure Resorts." There are no stories or editorials related to contemporary political questions in the only two issues of the paper that have been preserved; Redman's motto ("No Friends to Lose, No Enemies to Abuse") was reflected in the entire content of the paper. Redman was also an enthusiastic booster for local development. "Brady City has a bank. Why not Fort McKavett do likewise?" he wrote in an 1889 editorial. "[I]t is only a matter of time when this will be THE town of West Texas. Capital will be invested 


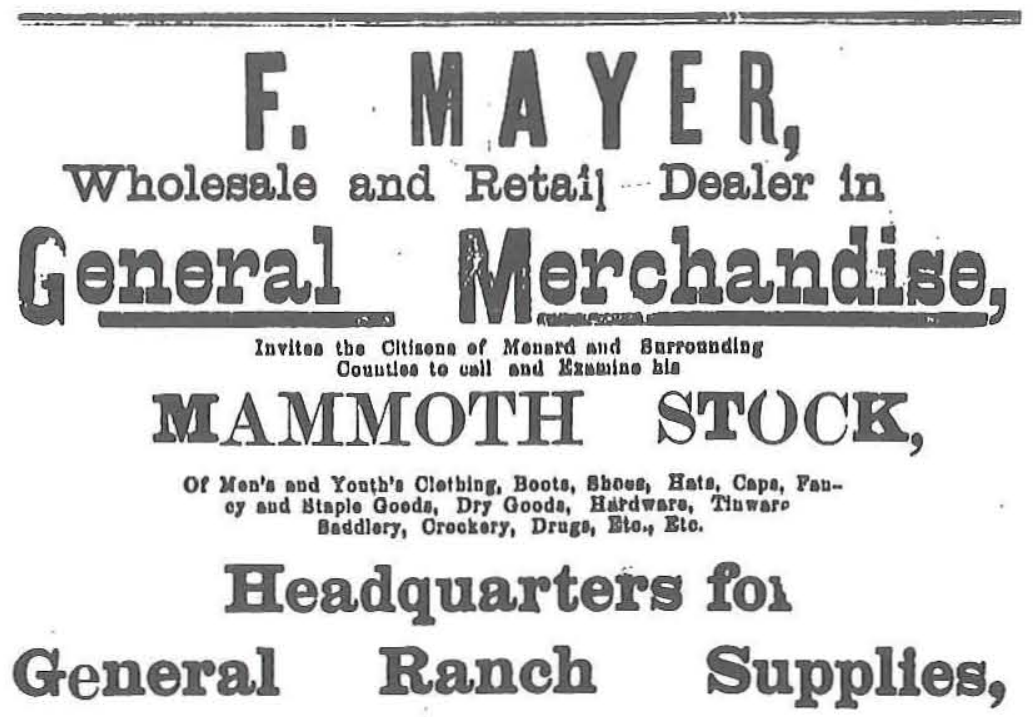

SALT, SULPHUR, LIME AND ORAIN, AT ROCK BOTTOM PRICES. - AGENT FOBTH ORLEBBATED BUBHYOBD WAGON. LIBFRAL ADVANCES MADE ON WOOL. Tolagraph and Tolaphome Offieo Attached

a

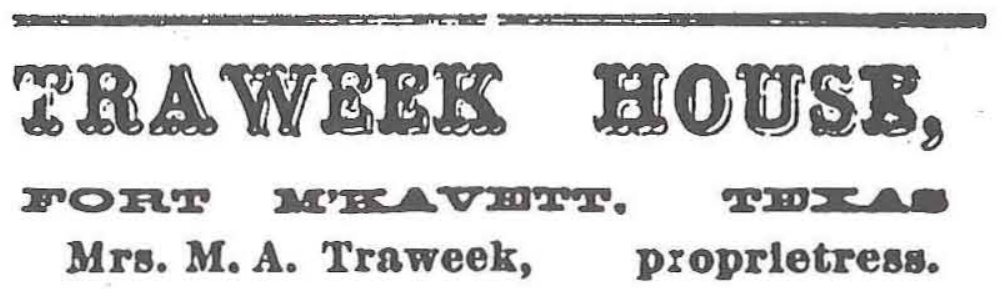

Tue most conrenient hotel to:, the stoge offee in town. Cevtrelly ocated. Tables oupl:er w.th the beet the mertet afords. Bede beat and elean. Chargos resoasble. Accommodation aret-clase.

b

Figure 5. Advertisements for the Fritz Mayer store and the Traweek House hotel (Fort McKavett Breeze, August 3, 1889).

here: new buildings will go up; different branches of business will open up; and, as here are found the best water facilities in this section, there is no doubt but that a woolen factory will be established as soon as the county becomes better known to the outside world" (Fort McKavett Breeze, 3 August 1889).

Fort McKavett's growth, and Redman's enthusiastic boosterism, were both rooted in the accelerating growth of agriculture, particularly ranching, in the surrounding area during the 1880 s; the arrival of "Colonel" Black was only one aspect of a larger phenomenon. The number of ranches or farms in Menard County increased from 36 in 1880 to 158 by 1890 ; the number of cattle in the area rose from about 10,000 to almost 34,000 during the same period, and the number of sheep jumped from about 28,000 to more than 93,000 . Some local landholders were also beginning to experiment with crops and irrigation techniques. William Columbus Redman and others hopeful for the county's development took note of these changes. "[T]he grass was never greener and ... stockmen were never more hopeful," Redman wrote in the August 3, 1889, edition of the Breeze after a tour of the countryside between Fort McKavett and Menard. "Corn and cotton are doing remarkably well ... Mr. O. Striegler [a local rancher] has in cultivation, and which he irrigates, 12 acres of land. He also has one of the most beautiful orchards in the county." Although crop farming had not yet become a significant part of the local economy, by 1890 about 100 acres were planted in cotton in Menard County, about 400 acres were planted in corn, and 423 acres were devoted to oats (U.S. Census 1880, 1890).

Redman's Breeze stopped printing about 1890 or 1891 , but as the surrounding economy expanded, the town continued to grow with it and became a more important locus for social and economic life in the area. Sam Wallick's store, for example, was not only a place to buy goods, but after about 1890 also the local post office where ranchers collected their mail and a social meeting place. 'When the Fort McKavett Masonic Lodge was established on December 7, 1893, with Sam Wallick as the chapter's first "Worshipful Master" (Rust 1994:9), the charter members included men who lived on ranches surrounding the town. Another center (and 
symbol) of community life and the interconnection between town and countryside was also established that year when St. James Episcopal Church, a frame building, was completed near the site of the stone St. James that now exists. Camilla Black, "Colonel" Black's wife, played a central role in obtaining the funds for the church by arranging for a $\$ 500$ grant from a missionary organization called the Double Temple. She also helped to organize its first choir and its Sunday school, while rancher Tom Ball donated the church's first organ and became the first organist. The congregation of St. James included people who lived on ranches as far as 20 miles from the town, and the church came to be used by other denominations which had no churches of their own (Menard County Historical Society 1982:77-78, 187; Williamson 1995; Winslow 1950:22-23). Shared social institutions like the church, the Masonic chapter, and the school bound the people from the town to those in the countryside in a number of ways, creating a sense of shared identity and community (Figure 6).

The 1890s included some bad drought years which hurt agriculture in the area; sheep farmers were undercut by changes in national tariff sched- ules, and the severe national economic depression which began in 1893 also affected the region. Nevertheless, during this period the population of Fort McKavett and the immediate surrounding area continued to grow and the economy became (at least temporarily) more diversified, partly again because of the efforts and imagination of William Black.

"Colonel" Black was one of the first to raise Angora goats in Texas, but by the early 1890 s he realized that his herd of more than 8,000 goats was reproducing too quickly and would have to be thinned out. By 1892 he had already established a tanning business on his ranchland near Fort McKavett (Carlson 1982:126-127; Texas State Gazetteer 1892). The catastrophic financial panic of 1893 , which subsequently plunged much of the nation into a painful and protracted depression, spurred Black to more-decisive measures. He sold off all his cattle and sheep, mortgaged most of his land, and offered to sell a thousand of his goats cheaply to the Armour and Company meat-packing plant in Chicago if the hides were returned to him. When Armour refused the offer, Black decided to butcher and process the animals himself for their

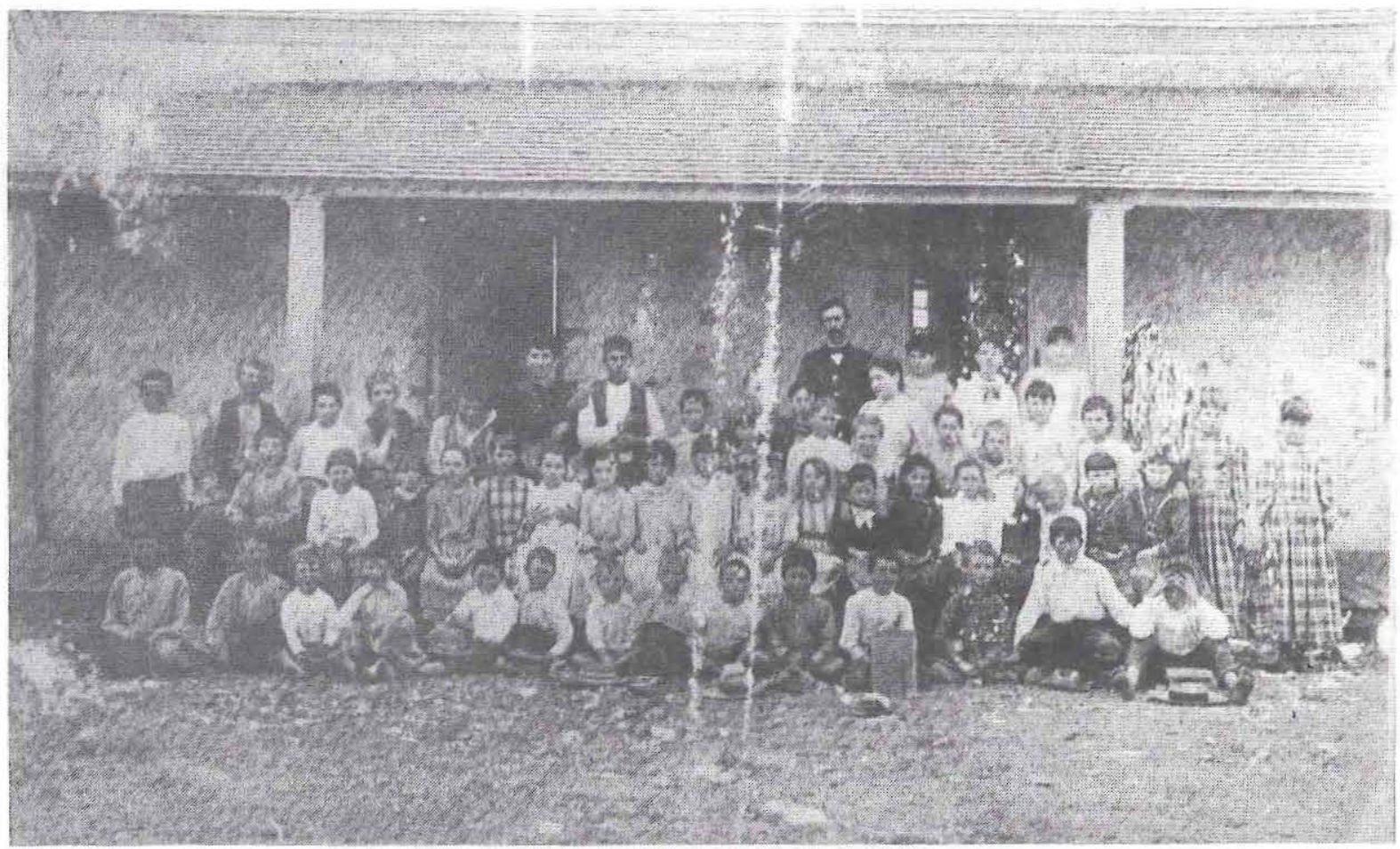

Figure 6. School class at Fort McKavett, 1894. Photograph courtesy of Fort McKavett State Historical Park, Menard County, Texas. 
meat, hides, and tallow. Borrowing money from Eastern connections, he dammed up the San Saba for a waterwheel to supply the necessary power, and by 1895 had constructed a small company town about $1 \frac{1}{2}$ miles west of Fort McKavett. Black's operation included a large building that housed the slaughtering and canning operations, a rending plant, a store, and housing for about 25 workers and their families. Most of the workers employed in the operation were Mexican-Americans. Other local women were hired to sew the tanned goat hides into gloves, robes, and other products, and local ranchers were encouraged to bring hides of jackrabbits, coyotes, and other animals to the tanning operation (Carlson 1982: 126-129; Winslow 1950:39-41). When Americans failed to buy the goat meat, canned in tins labeled as "roast mutton," and then "boiled mutton," it was finally marketed as "W. G. Tobin's Chili Con Carne" and sent to Europe for sale. The canning operation was shut down about 1896, as Black began to sell his goats rather than slaughter them. But while it was operating, the business helped a number of people in the area to get through the hard times of the depression. As Black's daughter Edith later wrote concerning the episode, "to this day everyone says my father distributed more money than any other man in the county" (Winslow 1950:39).

For the people living around Fort McKavett, the 1890 s were difficult times with certain bright moments. The county's sheep raisers suffered severe losses during the 1890 s, as prices dropped sharply because of the depression and new foreign competition. By 1900 , only about 19,500 sheep remained in the area. Fritz Mayer, long a mainstay of the local community, left the scene about 1895 , his holdings apparently sold to various interests, especially Green Baker, who became Sam Wallick's main competitor by 1896 (Carlson 1982:126-127, 166; Texas State Gazetteer 1896; U.S. Census 1890; USCMC 1900, 1910). The number of cattle in the county rose by almost 40 percent during the decade, however, and cotton production was increasing; by 1900 about 2,100 acres in the county were planted in cotton. Meanwhile, the county's population rose almost 80 percent, to 2,011. Fort McKavett's population increased by about 60 percent during the same period, and by 1900 an estimated 136 people lived in the town. Because Menardville had been severely damaged in a catastrophic flood in 1899 , at the beginning of the twentieth century Fort McKavett may have been the largest town in the county (Menard County Historical Society 1982:62; Smyrl 1991b:2; Texas Almanac 1904; U.S. Census $1880,1890)$.

The 1900 manuscript U.S. Census return for Menard County's Justice Precinct \#3, which included Fort McKavett, provides a snapshot of the community and some of the surrounding area at the time. The census enumerator counted 228 people living in Precinct \#3 that year; of these, 128 were male and 98 were female. Seventy-two residents, most of them male heads of household, reported occupations. These included 13 stockfarmers, 11 "day laborers," 11 "farm laborers," 13 "cattle herders," 5 shepherds, and 6 teamsters (USCMC 1900). Other cited occupations (USCMC 1900) are listed below, with names provided when the person was clearly or very probably living in the town of Fort McKavett at the time:

1. Postmaster and General Store [Samuel Wallick, age 62]

2. Dealer in General Goods [Alfred Wallick, 65]

3. House Servant [Juan Reyes, 19, in the Alfred Wallick household]

4. Hotel Keeper [Bridgett Lee, 55]

5. Livery Stable Keeper [Patrick Lee, 26, Bridgett's son]

6. School Teacher [John A. Tippit, 36]

7. Physician [Edward Deal, 33]

8. Dealer in Dry Goods [Greenberg Baker, 47]

9. Salesman [John Baker, 28, in father's household, above]

10. Minister of Gospel [William Mobley, 35]

11. Mechanic (?illegible) [John Regenier, 40, known to be blacksmith]

12. Carpenter (crippled) [Frank Barker, 50]

13. None Listed [Teresa Lehne, 64]

14. Seamstress [Rosie Crump, 20, and Katie Crump, 17, both single daughters living in household of James Crump, a day laborer]

15. Laundress [Juana Robles, 36, widowed sister of Clato Masa, a day laborer who may or may not have lived in the town]

These figures do not, of course, indicate at all accurately the size of the town's actual population in relation to the surrounding countryside, even when the 37 dependents in these households are 
added in; some of the farm laborers, for example, lived in households in the town, and some of the day laborers and teamsters (several of them in Haley family households) may well have lived in the town; moreover, a number of ranchers living in the surrounding area did not live in Precinct \#3. Nevertheless, the returns do provide a sense of the economic structure of the town and the kinds of opportunities available to the people living there. At this time Fort McKavett was still primarily a ranch center. Only 15 of the 48 heads of households in the precinct (fewer than 32 percent) had been born in Texas; while most of those born outside the state moved to the area from states in the lower south such as Mississippi, Louisiana, and Alabama, others had been born in states such as Pennsylvania, Virginia, Massachusetts, and Iowa. Almost 17 percent of the heads of households (the category does not include hired people living on the premises) were born outside the United States -natives of Switzerland, Germany, Canada, England, Ireland, Scotland, and Mexico (USCMC 1900).

The pronounced sex differential in the precinct reflected the relatively large number of single men who worked on ranches or in households as hired labor; many of these were Mexican-Americans, or Mexican nationals drawn into the area by the prospects of employment. E. Burbank, a local stock farmer, employed four single men. Of these, three were of Mexican descent and two had been born in Mexico. Juan Reyes, Alfred Wallick's house servant, was born in Texas, as was Lorenzo Rodriguez, a day laborer with a wife and three children. Clato Masa, a day laborer, had been born in Mexico but entered the United States in 1888; his five children were all born in Texas. In all, 22 people - or about 17 percent of the precinct's total population - were of Mexican descent (as determined by surnames); 12 were born in Texas, 10 in Mexico. No blacks were counted in the precinct (USCMC 1900).

By the beginning of the twentieth century, the town created on the site of the old fort had become a fairly stable community sustained, for the most part, by the trade of local ranchers. The "first generation" of the community, composed of those who had actually settled the site and had shaped it over the years, was aging but for the most part still intimately involved in the life of the town. During the next phase of the town's existence, between
1900 and 1940, that generation faded away, and new economic and social forces came into play.

\section{The Development of Fort McKavett, 1900-1940}

The area around Fort McKavett began to fill up more rapidly during the first decades of the twentieth century, as farmers from East Texas and other areas relocated to the region. In 1900 there were 204 farms or ranches in Menard County; by 1910 there were 331 , and by 1930 there were 401 . Many of the newcomers grew cotton. Land devoted to cotton production in the county expanded from about 100 acres in 1890 to about 2,100 in 1900 , and to more than 5,500 acres in 1910 ; by 1930 almost 8,000 acres in the county were planted in the fiber. The county's population grew steadily during most of this period, rising from 2,011 in 1900 to 4,447 by 1930 (U.S. Census 1890,1900 , $1910,1920,1930)$. For a time, this influx of people, money, and energy helped to buoy the prospects of Fort McKavett; but when the railroad built into Menardville in 1911 and was not, as hoped, extended to McKavett, the town's future was sealed. The town continued to grow slowly into the 1920 s, and then slipped into the beginning of a long decline.

Crop farming had begun around McKavett in the late 1880 s, but only in the early 1900 s did it begin to shape the economy and society of the area. At about this time, Thomas Ball, a prominent local rancher who had moved to the area from England years before, undertook an extensive project to improve his land. Hiring a number of laborers, many of them Mexican-Americans or Mexican nationals, he dammed up the San Saba, dug irrigation ditches, and built terraces. Other ranchers and farmers also began irrigation projects, while others opened new land to dry farming; before long, about 600 acres of land near McKavett north of the San Saba were devoted to cotton. Two gins were built in the vicinity of Fort McKavett during this time, one by Thomas Ball and the other by D. C. Ogden, another local rancher; one of these gins was located about a mile south of the town (Lehne 1995; Menard County Historical Society 1982:148). While cotton was the most popular new crop, others were planted too, and at least one truck farm specializing in produce was established in the McKavett area 
during this time (USCMC 1910).

A number of farmers moved into the vicinity in the early twentieth century. Alfred L. and Dora Pollard, for example, came to Texas from Oklahoma, moving "from one farm to another in order to make a better living." After one try in Concho County, the family moved to the Fort McKavett area about 1909, where Alfred worked for Thomas Ball before settling down on his own place (Menard County Historical Society 1982:511). The majority of the newcomers, however, had been born in Texas, and many of them had moved from east Texas in search of new opportunities (Menard County Historical Society 1982; USCMC 1910). By 1910, the influx of crop farming had helped to redefine the economics and culture of the area: on the census taken that year, only 6 local landholders described themselves as "stock farmers" or ranchers, while 20 described themselves simply as "farmers." Of these, 11 did not own the land they worked; most of them were probably sharecroppers (USCMC 1910).

By the early twentieth century, Fort McKavett was already becoming a center of lively social activities for the growing number of people in Menard and Schleicher Counties. Large community picnics and barbecues were held along the San Saba near town, and dances at the schoolhouse or in the hospital building attracted people from miles around. Day-long festivals often began with a baseball game, followed by barbecue and then dancing. John M. Treadwell, who grew up on a ranch and attended the McKavett school, went to a dance in the town in 1904. "I attended a dance at McKavett last night, had a fine time," he wrote in his diary. "There were about 23 girls there. We danced until after four o'clock." Band concerts were often a part of the picnics; on June 27, 1906 , a large picnic crowd in the town was entertained by the "Menardville Mexican Band." Political candidates addressed the crowd, and then a dance ensued. On New Year's Day 1908, a Leap Year Ball was held in the town. For this event, women were expected to ask the men to dance (Menard County Historical Society 1982:62-63, 643-644).

Perhaps anticipating further development of the town, L. L. Ball (Lewis L. Ball, the son of Thomas Ball) had begun to buy tracts in Fort McKavett as early as 1902, when he purchased from Fritz Mayer a large lot in the northeastern corner of the old fort site. In 1908, Ball bought much of the townsite from the heirs of John Chapman Stodart (Ball Deed 1908, CTFAF; Survey Map of Fort McKavett State Park [SMFM], CTFAF). After the purchase, Ball's holdings in the town included most of the western half of the town, including the hospital building, which became a family residence after Ball's ranch house burned (Ball Deed 1908, CTFAF; "Facts Revealed from Record Search," Robert G. Flutch Tract File, CTFAF; Menard County Historical Society 1982: 148; SMFM, CTFAF). Another local rancher, Robert Flutsch (the son of John Flutsch), bought a lot from L. L. Ball in 1910; soon afterward, he ordered a prefabricated frame house from the Sears and Roebuck mail-order company. The house was shipped by rail to San Angelo, then hauled down to the McKavett lot and assembled, complete with fixtures, rugs, and curtains. Although the house was gone by 1995 , the stone smokehouse built by Flutsch behind his house still stands ("Facts Revealed from Record Search," Robert G. Flutch Tract File, CTFAF; Garza 1995; Menard County Historical Society 1982:286; Williamson 1995). A frame addition and wrap-around porch were added to one of the old stone fort buildings in the town about the same time as the Flutsch home was constructed; in 1995 this house was dilapidated but still standing, and known as the Saucedo house for the family who lived in it in the 1970s (Figure 7) (Saucedo 1995). A Church of Christ congregation was established in the town sometime during the 1910 s or 1920 s, and in the late 1920 s a frame church was built just southeast of St. James Episcopal; the state highway circling the park runs across the lot today (SMFM, CTFAF; Williamson 1995).

These construction projects, and L. L. Ball's continuing interest in acquiring land around the Fort McKavett townsite, indicate that the town was experiencing a minor growth spurt during the 1910 s and 1920s. A telephone company, with a clientele of about 100 local connections, also was created in the town about this time. In 1919, the county's first oil well was drilled on L. L. Ball's land about 2 miles south of the town (it'was a dry hole). These investments indicate a certain contemporary optimism about the town's future; the area's rising population, spurred by the growth of agriculture in the vicinity, would have helped to reinforce that optimism. The population of Justice 


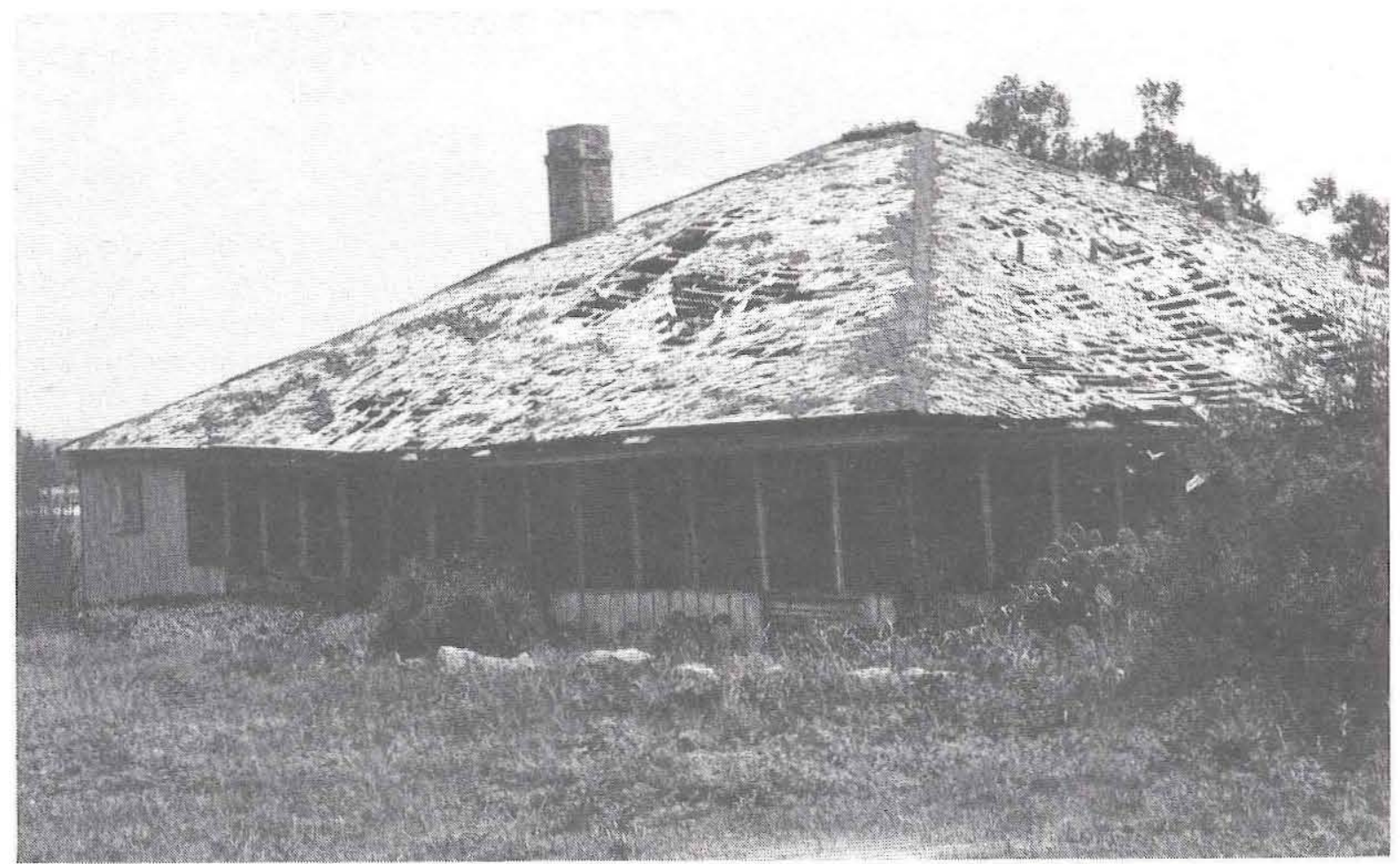

Figure 7. Southern elevation of the "Saucedo House" in eastern section of Fort McKavett. Photo taken June 1995 by John Leffler.

Precinct \#3, which included Fort McKavett, grew to 354 by 1910 and to 378 by 1920 ; meanwhile, estimates of the town's population peaked between 1915 and the late 1920 s, when about 150 people lived there (Menard County Historical Society 1982:17; Texas Almanac 1929; Texas State Gazetteer 1915). By 1920, the town had grown to include at least three stores, at least one saloon, a barbershop, and perhaps a filling station or garage (Saucedo 1995; USCMC 1920). This sense of optimism must have been reinforced in 1921, when the area received a lot of rain, so that local cotton farmers harvested a bumper crop just as cotton reached 45 cents a pound, the highest price in memory (Menard County Historical Society 1982: 665).

Even as the town was reaching its highest level of development, the "first generation" of McKavett was passing from the scene. By 1920, Sam Wallick no longer lived in McKavett and the family wealth was gone. His son John was reduced to working as a day laborer; he and his family apparently rented rooms in the hotel (List of residents of various buildings in the town, in Treadwell n.d.; USCMC 1920). While in 1915
G. Baker still operated the store once occupied by Fritz Mayer, by that time the Wallick store had apparently fallen into the hands of J. A. Champie, who ran the town's other general store. The post office, which after so many years in Wallick's store had become almost a symbol of community and continuity, apparently moved to the hotel about this time. Mrs. Angie Crump became the town's postmistress in 1914 and served until 1918; she was followed by Mrs. Zula Wilhelm until Mrs. Ruth Ellis took the job in 1920; she in turn was followed by Mrs. Callie D. Pullen, who remained postmistress until 1925. By 1915 Bridgett Lee no longer operated her hotel, and none of her family members lived in the town by 1920 . John Regenier, who had been the town's blacksmith for many years, was also gone by 1920 , and none of his family appeared on the census that year: J. D. Hodge, 56 , had become the new blacksmith by that time. Hodge quickly established a reputation for his skillful use of the hammer and tongs (Figure 8). A transitional figure, Hodge could repair automobiles but preferred not to work on them (Lehne 1995; Saucedo 1995; Texas State Gazetteer 1915; Treadwell n.d.; USCMC 1920; Williamson 1995). 

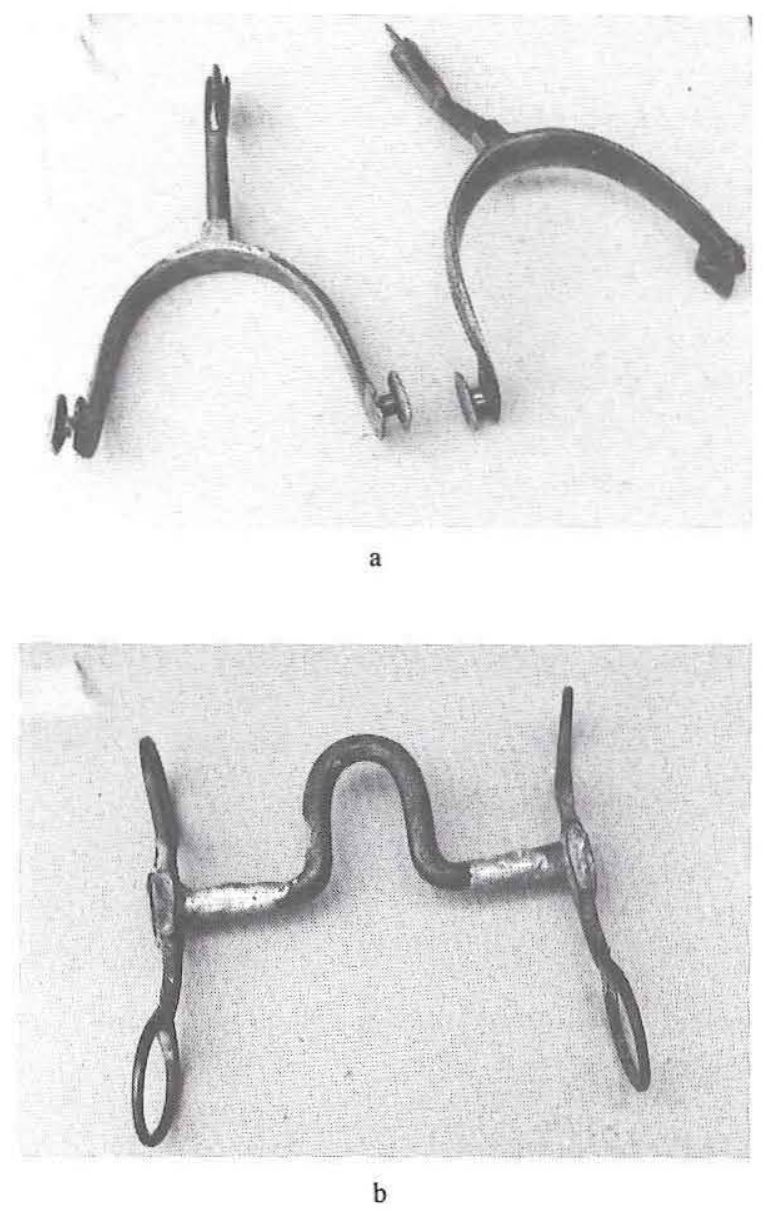

Figure 8. Items forged by J. D. Hodge, Fort McKavett's blacksmith in the 1920s. (a) Spurs of tarnished brass with silver, ca. 1920s; (b) bit, ca. 1920s.

In early 1929, Fort McKavett was invaded by oil scouts looking for "black gold" in the area, creating a certain excitement among local landholders; some received as much as $\$ 25$ per acre for oil leases, considerably more money than they had paid for the land originally (Lehne 1995; San Antonio Express 1929a). Farmers in the Menard County area had also been pleased by a series of good years during the 1920 s, and 1929 brought another bumper crop. Perhaps encouraged by these developments, in October 1929 W. B. Arnold bought the two long stone barracks buildings and the town's hotel (San Antonio Express 1929b).

Although by the late 1920s Fort McKavett was probably more populous than ever before, in a sense its prosperity - if that is the proper word - was as old-fashioned as J. D. Hodge, the town's recalcitrant blacksmith. It was prosperous by the standards of a nineteenth-century small town. Although McKavett had a telephone system, it had no electricity or modern water system; the students in the town's school still did their lessons by the light of a kerosene lamp, and during the winter the schoolhouse was heated by a stove (Powell 1940: 34). When the railroad had built into Menardville (thereafter called Menard) in 1911, and then did not extend its tracks west to Fort McKavett, McKavett was left simultaneously too isolated from "civilization" and too close to Menard and San Angelo (both served by rail) to function effectively as a trade center. This would become particularly important after the 1930s, when paved roads began to be completed across the county, and ranchers even in the McKavett area could make the trip to Menard in a matter of minutes rather than hours. Finally, Fort McKavett's temporary "prosperity" during the 1910s and 1920s was based on an agricultural system that simply could not be sustained over the long run in western Texas.

In late 1929, thanks to the onset of the Great Depression, cotton prices dropped dramatically and hit "rock bottom," as one local resident remembered. And not much oil was ever found near McKavett (Lehne 1995; Menard County Historical Society 1982:17, 665). Cotton farming all but disappeared from Menard County during the Great Depression of the 1930s; by 1940 , only about 1,500 acres were planted in the crop. Ranchers also suffered, and agonized when federal officials from the Agricultural Adjustment Administration insisted that the many cattle slaughtered in the county under the government program be buried immediately. Often ranchers would let townspeople and others know when their cattle were about to be slaughtered so that at least some of the meat could be eaten (Lehne 1995; U.S. Census 1940; Williamson 1995). Although road projects sponsored by the federal Works Projects Administration helped to provide jobs for some people in the area, the foundation of Fort McKavett's existence was severely undermined; population fell away, and businesses declined. As part of a state celebration of the Texas Centennial, in 1936 Fort McKavett was designated as a state historical landmark, and authorities set a memorial stone into the ground south of the parade ground (about where the town's bandstand once stood). "I knew McKavett was dead," one resident remarked, "but I didn't know it needed a tombstone" (Menard 
County Historical Society 1982; Williamson 1995). By the early 1940s, the Texas Almanac (19431944) reported only two businesses in the town.

\section{The Last Years of the Town}

In the late 1940s fires destroyed the old commanding officer's building, which had been used as a boarding house, and also the building that once housed G. Baker's store and the Masonic Lodge. A new cinderblock lodge was built on the site of the old Baker place, but as late as 1967 no new business had been formed to replace the lost store. Despite a 1948 state highway map that shows six businesses in the town, by 1950 Fort McKavett probably had only one or two. The McKavett school district was consolidated with the Menard district in the late 1940s, and by 1951 the old schoolhouse had been closed. The town's decline was cemented by an intense drought that afflicted the region between 1950 and 1957. A number of families who had lived in or around Fort McKavett for years (including the Wallicks) left the area at about this time. J. D. Hodge, the town's old blacksmith, died in 1953; he was spared a pauper's grave when various citizens contributed to give him a proper burial (Garza 1995; Lehne 1995; Menard County Historical Society 1982:38; Smyrl 1991a:1; Texas State Department of Highways and Public Transportation map of Menard County, 1936/48; Tolbert 1967).

Meanwhile, the ethnic balance of the town had shifted significantly. Sometime during the late 1930 s, the number of Mexican-Americans and Mexican nationals in Fort McKavett began to rise noticeably. Clara Saucedo, born in 1905 on a ranch about 8 miles southeast of Fort McKavett, moved to the town about 1918 and lived there until the 1970s. According to Mrs. Saucedo, MexicanAmericans and Mexican nationals began moving to the area in numbers during the late 1930s looking for work. Housing was so scarce that many Mexican-Americans and immigrants - possibly as many as 60 at a time-camped in and near Fort McKavett in tents, concentrating in the area that later became the site of the St. William's Catholic Church. Others lived in a boarding house, and after that burned down, some lived in the open basement of the place (Saucedo 1995). Her account is supported to some extent by that of Edith Black Winslow, who described a large stone building, "two stories high," which once had been used, she wrote, "as a sort of apartment house for Mexicans." By 1950 it had been "burned to the ground, leaving only the rocks and high chimneys" (Winslow 1950:24). Since the commanding officer's building was the only one two stories high and containing a basement, and it burned about that time, the two accounts coincide. In 1947, the mission church of St. William (Figure 9) was built on the site of the former campground, with the aid of the Catholic Church Extension Society. In 1950 , the church served about 165 parishioners, including more than 100 children (Amarillo Reporter, 2 October 1953). Beginning in the late 1930s, Mexican-Americans began to buy properties in the area. The Hernandez family bought the "Long Building" barracks, which was still in use, in 1936. Although the building had no running water, the rooms were assigned to various Hernandez families by Raphael Hernandez, the owner of the building. About 1943, the Saucedo family bought their home, which still stands today (see Figure 7). In subsequent years, MexicanAmericans bought other properties in the area; according to one observer who visited the town in the early 1970s, the town's Mexican-American community at that time occupied most of the eastern part of the town. According to another informant, who preferred to remain anonymous, Fort McKavett became an important center for illegal Mexican immigration during the late 1950s and continued to play that role into the 1970 s, when most of the site was acquired by the state for the creation of the state park. According to this informant, "coyotes" guided illegals to the area for a fee, sometimes paid by the immigrant, sometimes by the employer. Immigrants were deployed into agricultural labor, or transported to Dallas, Houston, or even Chicago to work on construction projects in those cities.

Meanwhile, the old community survived, sustained by the Mexican-Americans, the immigrants, and the old ranch families who had grown up in the area and identified with the town. A new stone building for St. James Episcopal Church was built in Fort McKavett in the early 1940s to replace the old frame structure which had been damaged in the late 1930s by high winds (Menard County Historical Society 1982:77-78; Williamson 1995). Earl Haley's "Fort Cafe and Dance Hall," a large cinderblock building near the center of the 


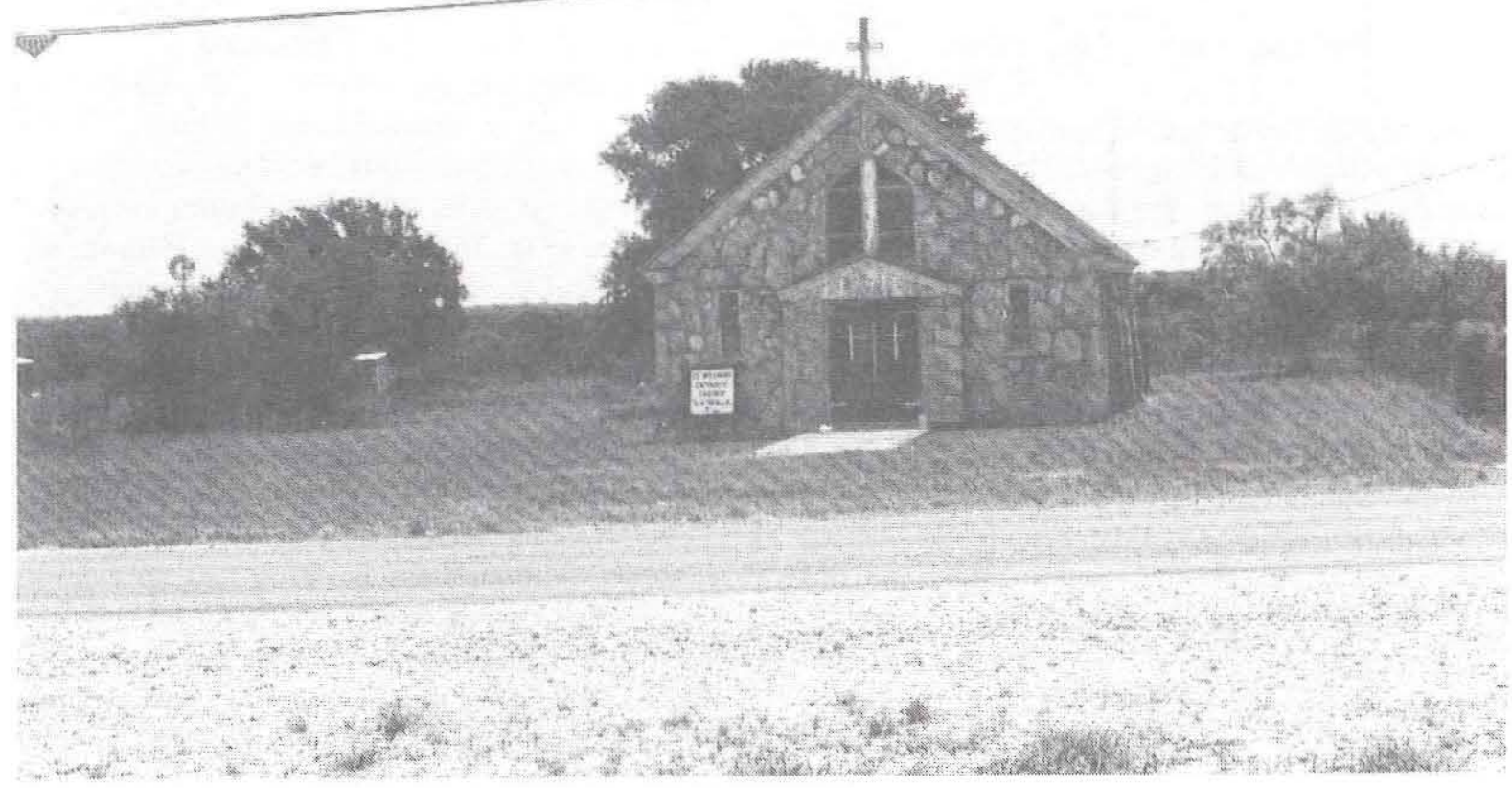

Figure 9. St. William's Catholic Church, built in 1947, no longer in use by the 1980s. Photo taken in June 1995 by John Leffler.

town, was a popular center of county social life for many years after it opened in the 1940s; it did not close its doors until after 1975, when it was condemned by the State of Texas and purchased to become part of the park (Garza 1995; Earl Haley Tracts File, CTFAF; Williamson 1995).

Since at least the 1930 s, when the town had noticeably declined, efforts had been made to encourage the state to acquire the Fort McKavett site (Menard County Chamber of Commerce 1937: 12). Subsequently, a number of articles were published in various newspapers around the state describing the haunting beauty of the site and publicizing the cause. Mrs. Francis (Talbot) Fish, a Menard County resident who had grown up in the town, actively promoted the preservation of the site, and in the mid to late 1950s she helped to organize a group called Fort McKavett Restoration, Inc. Her sister, Mrs. Ada "Pat" (Talbot) Williamson, also became an important member of the organization. To raise money, the group sold memberships for $\$ 50$, and during the 1960 s held dances in the old schoolhouse. By 1967 Fort McKavett Restoration, Inc., had raised enough to buy the "Long Building" barracks from the
Hernandez family for $\$ 2,000$; the property was then donated to the state for preservation. At about the same time, Menard County agreed to donate the old schoolhouse (Austin American, 14 June 1964; "Schoolhouse Tract" File, CTFAF; SMFM, CTFAF; Williamson 1995). By the late 1970 s, the state had acquired most of the site of the old town, sometimes through "friendly" condemnation suits that turned decidedly "unfriendly." Inhabitants usually relocated to nearby towns, particularly Menard, Junction, El Dorado, and San Angelo. Preservation efforts were already being conducted on some parts of the old fort before the entire site was completely acquired. Some elements of the old town, such as the Masonic Temple (on the site of G. Baker's old store) and St. James Episcopal Church, are still used by local inhabitants.

Although as late as 1995 some of the former inhabitants had bitter memories of their dislocation, others accepted the creation of the park without rancor. Many of the park's visitors are people who grew up on or around the site and want to revisit old memories; quite a few return to be married or buried there. Louis Lehne, a grand- 
son of the man who established one of the first stores in Scabtown, grew up on a ranch just outside McKavett during the 1910s and 1920s and taught school there during the 1930s. He lives in
Menard now but remembers the old town fondly. "When people ask me where I'm from," he says, "I still say Fort McKavett" (Garza 1995; Hernandez 1995; Lehne 1995; Saucedo 1995). 



\section{RESEARCH DESIGN AND METHODS}

The research design presented here guided completion of the report. Report objectives, data sources, archeological field methods, analytical techniques and limitations, and diagnostic artifact definitions are discussed below.

\section{REPORT OBJECTIVES}

Fort McKavett State Historical Park (41MN2) was developed as mandated by the passage of the Historic Sites and Structures Act in 1967 to acquire, develop, and interpret important historic sites and structures for the benefit of the people of Texas. Fort McKavett contributed to Texas's heritage during the periods from early statehood until the beginning of the Civil War, and from the end of the Civil War until the fort was abandoned by the military (Texas Parks and Wildlife Department 1975:5, 15). The site is primarily important for its pre- and post-Civil War military occupations.

The planned development of Fort McKavett has been phased depending on the availability of funds and the rate at which buildings were acquired from private owners. During each phase, historical, archeological, and architectural research were followed by stabilization or restoration (Black and Ing 1980:2). The cultural resource management objectives of the project as stated in the Fort McKavett historic preservation plan (Texas Parks and Wildlife Department 1975:5, 15) were to restore fort buildings authentically, to adapt restored fort buildings for park facilities, and to include unobtrusive support facilities and limited, unobtrusive day-use recreational facilities in accord with the historical integrity of the site. Buildings generally have been restored to their 1875 appear- ances (Black and Ing 1980:67), again emphasizing the site's significance as a military outpost.

Archeological research objectives of the project were to investigate and stabilize archeological features. One focus of the work was to identify and document post-military modifications and thus to contribute information for restoration (Black and Ing 1980:67). The work focused on the details missing from the records, numerous discrepancies between written documents and actual field measurements, and the identification of civilian modifications. The excavations, for the most part, involved applied or developmental research designed to discover specific details about architectural features figuring importantly in the site's restoration and interpretive potential, e.g., locations and dimensions of missing doors, windows, and porches, and types of flooring and configurations of formal walkways shown on military maps but no longer visible on the surface (Black and Ing 1980:2). It should be emphasized that the primary goal of the archeological work was to collect architectural data for restoration; the collection of military-era artifacts for interpretation was a secondary goal. Archeological work ranged from surface collection to extensive excavations in structure interiors and in associated yards and focused on the military occupation.

This report of the 1978-1990 archeological work at Fort McKavett has a single objective consistent with TPWD's cultural resource management and archeological objectives for Fort McKavett: to describe military-era structures and features and their associated artifacts as a contribution toward producing an illustrated cultural history of this state historical park. The Fort McKavett archeological remains may be compared 
in only a general way with those from other Texas forts because of lack of contemporaneity, differences in building materials, differences in excavation objectives and techniques, and, in particular, the small military and military-period artifact assemblage from the 1978-1990 work at Fort McKavett. Limited comparisons are made with the earlier work at Fort McKavett (Black and Ing 1980) and with recently reported work at Fort Richardson (Black and Kegley 1995).

\section{DATA SOURCES}

Documentation of the archeological remains consists of plan maps of structures, features, building rubble, and sediments; profiles of excavated deposits; black-and-white photographs and color slides; field notes and sketches; and artifact catalogs. Records received consist of 2 drawers of maps and photographs, 4 binders of field notes, 10 binders of artifact catalogs, 9 binders of photographs, 5 binders of computer catalogs, 4 binders of artifact analysis catalogs, 1 binder of artifact count charts, and 1 binder of miscellaneous notes. The artifact collections were received in 141 filesized boxes.

Much historical and architectural research has been done by TPWD, and some of the results of that work are used in this report. Historical and architectural documentation dates back at least to the 1936 Historic American Buildings Survey records of the fort. Historical research has included land grant, chain-of-title, population census, and military records on the fort (such as Mansfield's 1856 inspection, medical history of the post, and the end-of-fiscal-year quartermaster inspection reports) at the National Archives as well as informant interviews. Architectural documentation includes Historic American Buildings Survey photographs, area plan maps, building foundation plans and elevations, photographs, and materials research. In addition, a photogrammetric map of the site and aerial photographs are available. Historical maps of Fort McKavett used systematically in this report are from ca. 1871 (Texas Parks and Wildlife Department 1975:158), 1874 (Sharpe and Horton 1875; Texas Parks and Wildlife Department 1969), 1875 (Sullivan 1981:42; Texas Parks and Wildlife Department 1975:161), and 1876 (Black and Ing 1980; Green 1969:8).

\section{ARCHEOLOGICAL FIELD METHODS}

Archeological field methods described in the field notes and by Art Black (personal communication, 1995) were selected to maximize architectural description and to recover artifacts to date the associated architectural features. Civilian-era structural modifications also were recorded and artifacts recovered, and these data were important to site restoration and interpretative goals. These methods were intended to provide details important in the site's restoration and interpretation focusing upon the military period ca. 1875 .

Military-era buildings at the fort were constructed around two parade grounds and are oriented consistently with respect to this historical grid. During the archeological work, a buildingspecific grid system was used to facilitate placement of collection and excavation units to examine architectural details. Excavations in and around structures not containing deep deposits were limited generally to tracing wall lines, searching for doors and windows, and exposing interior features such as fireplaces and interior walls and exterior features such as walkways, porches, door or porch steps, fences, and walls. Architectural features visible at the surface were examined as part of the structure foundation with minimal reference to the horizontal grid system. Vertical control was maintained by reference to the present ground surface or by reference to state park benchmarks. Measurement was in the U.S. Customary System of feet and inches or tenths of feet to conform to original military specifications for building construction and post layout (Black and Ing 1980:69-70). All field measurements in this report are taken directly from the field records, and no conversions to metric, rounding, or additions of zeroes have been made.

Sediments were excavated both in arbitrary levels and by cultural strata, depending upon the thickness and variability of the deposits and whether strata were definable. Tools used included shovels, trowels, brooms, and, for vegetation clearing, rakes, hoes, and root cutters. Most compact deposits were dry screened through 1/4inch mesh. Exceptions were deposits containing recent trash or associated with modern construction, landscaping, or maintenance activities or those adjacent to units with low artifact yields. Deposits such as unconsolidated subfloor sediments 
were dry screened through $1 / 8$ - or $1 / 16$-inch mesh and occasionally wet screened through $1 / 16$-inch mesh.

Vegetation clearing was the first step in recording buildings that were no longer standing. Surface collection and mapping of any artifacts and features visible on the cleared surface was the second step. Particular emphasis was placed on drawings of construction details, such as fireplaces, wall foundations, etc. The extensiveness of excavation depended on the building's intended function in the park as well as the inherent significance of the deposits and features. Where extensive areas, such as a room or a yard, were excavated, grids were established and units excavated in alternating checkerboard fashion or contiguously for significant features or to follow architectural alignments. Profiles of excavation units or balks were drawn across these extensively excavated areas.

Field procedures were tailored to the often excellent preservation of the buildings and their occupation and maintenance until recently by civilians. In rooms with standing or visible foundation walls in which extensive excavation was planned, the interior space was divided into approximately equal units $1-3 \mathrm{ft}$ wide. Where interiors were relatively intact, wood floors were in situ, floor joists were visible, and the floor was not scheduled for extensive restoration work, the grid was based on floor joist spacing rather than increments in even feet. If reconstruction was planned in an area with intact deposits, the grid was based on the size of the planned foundation, such as a porch footing, that would impact those deposits. Because of the architectural focus of the work, the emphasis was on feature-shaped units rather than standard-sized units.

The excavation techniques were modified to disturb in situ architectural details as little as possible. In relatively intact interiors, modern trash and furnishings such as linoleum and baseboards were removed and wood floorboards were swept, photographed, numbered for replacement after restoration, and removed board by board. Deteriorating interiors often had been used for modern trash disposal, and this trash generally was removed without screening to expose the wall fall and older trash beneath, which were excavated and screened.

\section{ANALYTICAL TECHINIQUES AND LIMITATIONS}

Master plan maps of each structure excavated were compiled during analysis and reporting using schematic and measured maps and notes produced during the fieldwork. These plan maps provided visual summaries of the archeological work in each structure.

Since little 1978-1990 work was done in barracks, there is no potential for comparative analysis of enlisted mens' barracks and officers' quarters at Fort McKavett. And, although there is some archival information on officers'-quarters occupants at the time that annual fort inspections were made, there was such a rapid turnover of occupants that it is not possible to relate the archeological assemblage to specific individuals. In addition, because of the thin mantle of sediments in most proveniences at Fort McKavett, stratigraphic separation between the military occupations and the immediately subsequent civilian occupations is impossible, and the civilian and military occupations can only be separated based on artifact functions and dates.

Completeness of records (and, to a lesser extent, artifacts) received is a concern as is probably inevitable in a project that began 16 years ago and that has experienced considerable turnover in field and laboratory personnel. There are few field records of some of the archeological work, and in some cases gaps in the existing records are apparent (e.g., field maps unaccompanied by field notes). In addition, photographs from the 1985 season are lacking, as are photograph logs for many of the 1978 season photographs. Further problems noted include inconsistent provenience designations and duplicate lot numbers. Some of these problems were resolved during this analysis, but others were not.

The level of reporting effort for each structure and feature is commensurate with the level of fieldwork effort. Extensively excavated structures such as Officers' Quarters 4 received the greatest attention because their potential for contributing useful typological and distributional information is greater than that of structures with limited collections and excavations. Those structures on which little archeological (and stabilization) work was 
done and those structures with few test excavations generally have extremely limited artifact assemblages and low potential for analysis and comparison.

Archeological structures were compared with historical data such as 1870 s maps and 1890 s and early 1900s photographs, and the depth of the comparison depended on the amount and location of archeological work done on the structure. Reference is made to artifact distributions for extensively excavated contexts when sufficient military-era artifacts were recovered, but no assemblages were large enough for distributional data to be meaningful. Since excavation methods were directed toward architectural objectives, rather than toward systematically sampling the site for artifacts or obtaining a representative sample of artifacts, the potential for distributional study was never great.

\section{MILITARY AND MILITARY-PERIOD ARTIFACT DEFINITIONS}

The artifact analysis focused on artifacts used by the military. Artifacts analyzed include those that are specifically military in function and those dating to the 1853-1883 period of military occupation of the fort. These artifacts are described in the text and/or tables, and a sample is illustrated. Twentieth-century artifacts are present for each structure reported here, but these materials were not analyzed because the primary significance of the site (and the reason that it was acquired by TPWD) stems from its role as a fort associated with early frontier defense (see Appendix B).

Examples of analyzed nineteenth-century artifacts include cartridge cases; military buttons and other personal accoutrements; decorated and marked ceramics; and wine, beer, or liquor bottles with lips made with finishing tools and pontil marks. Artifacts not analyzed include decorated ceramics dating to the turn of the century or twentieth century, such as decal, light repoussé molded, and gilded types; window glass; and nails. Faunal analysis is restricted to materials from Officers' Quarters 4, as stated in the Request for Proposals, since many of the other bones are postmilitary in origin and were in disturbed contexts.

\section{Military Artifact Analysis}

Attributes used in analyzing the military artifacts are those represented in published archeological, historical, and collector literature. For ammunition, percussion caps were characterized as either musket or pistol sized. Lead bullets and shot were measured in inches and weighed in grams and then converted to grains for possible caliber identification. Other attributes, such as number of cannelures, presence of sprue marks, and shape were noted. The distortion of some of the bullets and shot from firing and impact made identification difficult. Cartridge cases were typed as rimfire or centerfire and identified based on case, rim, and length measurements in inches in comparison with Barnes (1989). Barber (1987) was used for rimfire identification and for correlation of rimfire tool marks with particular manufacturers. Reuland (1991) and Waite and Ernst (1980) were used for .45-70 and other United States government cartridge identifications. Headstamps were identified primarily using Barber (1987) for manufacturer dates. Cup type for .50-70 cup-primed cases, crimp type for $.45-70$ cup-primed cases, and primer type for externally primed cases were identified primarily using Reuland (1991). The crushing, breakage, and corrosion on some of the cases made estimation of dimensions necessary, headstamps illegible, and some attributes impossible to observe; the resulting questionable identifications are noted as approximately equal to or with question marks in the tables. Insignia, buttons, and equipment attributes and patterns corresponding with dated changes in military specifications were analyzed to date the assemblages. Buttons are discussed according to size (corresponding to the article of clothing to which they were attached) and branch of service designation or lack thereof.

\section{Ceramic Analysis}

Decorated ceramics and ceramic marks potentially dating to the military occupation were removed from the general Fort McKavett collection for further analysis. In addition to provenience (by structure or, for Officers' Quarters 4 only, by room 
or exterior provenience), the following attributes were recorded for each sherd: ware, portion, vessel form, rim shape, decoration type and pattern, colors, mark type and sketch, and comments. Marks were compared with DeBolt (1988), Gates and Ormerod (1982), Godden (1964), Kovel and Kovel (1986), and Lehner (1988). The ceramic assemblage data are summarized in tabular form. Temporally diagnostic sherds are described by decoration type in the text, and photogenic examples are illustrated. Spatial and temporal distributions of the small assemblage were examined.

Sherds of similar decoration types and patterns were examined to see if they were possibly from the same vessel and would cross-mend. An attempt was made to identify the flow and transferprinted patterns using photographs in antique collectors' publications. At least 2,400 transfer patterns and 2,700 flown transfer patterns illustrated in published references (Coysh and Henrywood 1982, 1989; Gaston 1983, 1994; Lockett 1972; Lockett and Godden 1989; Moore 1903; Snyder 1992, 1994; Williams 1978, 1981, 1986, 1988; Williams and Weber 1986; Wood and Wood 1975) were examined. The sponge-stamped pattern was compared with illustrations in Robacker and Robacker (1978). The molded patterns were compared with illustrations in Wetherbee (1985).

\section{Bottle Analysis}

Bottles were identified as to probable contents, but most of the bottles are fragmentary and none have preserved labels or identifiable embossing related to contents; resulting possible identifications are noted with questions marks in the tables. Glass color and manufacturing attributes such as use of a finish-forming tool, pontil marks, ring-shaped base parts, turn molding related to finish, and base type identification were noted. Jones and Sullivan (1989) were used for manufacturing attributes, and Switzer (1974) and Wilson (1981) for bottle type.

\section{Personal Artifact Analysis}

The color of tobacco pipes was noted, although variations in color relate only to position in the kiln; decoration pattern (all have molded decoration) and marks were noted. Coins are described using Yeoman (1975). Tokens are described using Fowler et al. (1973) on Texas trade tokens. The one marble recovered was identified using Randall (1979) and Grist (1993).

\section{CURATION}

The nineteenth-century and military artifacts pulled for analysis were returned to TPWD packaged separately as an analyzed collection; this procedure conforms with Texas Archeological Research Laboratory guidelines. An archival tag listing the Prewitt and Associates project number, the lot number, and the number of artifacts removed was placed in the original bags to note that artifacts were removed, and these materials were reboxed for return to TPWD as they were boxed when received by Prewitt and Associates. The entire collection was returned boxed approximately by structure first and then by lot. Diagnostic artifacts are organized by structure, room, feature, and lot; artifacts are packaged in 2-mil Ziplock bags with an archival tag listing the Prewitt and Associates project number, the lot number, provenience data, analysis category, and number of specimens. These collections were returned in file boxes supplied by TPWD. In addition, records and photographs generated during this project by Prewitt and Associates were organized in notebooks and returned with the collections. The records and photographs generated include analysis notes, coding forms, photo logs, and artifact photos.

Recommendations were made to TPWD regarding the handling of nondiagnostic artifacts still in paper bags, but these were not repackaged as part of this project. Artifacts with active decay (mold, mildew, etc.) were pulled and boxed separately with general recommendations given for their treatment/disposition. 



\section{STRUCTURES AND FEATURES}

\section{OFFICERS' QUARTERS}

\section{History and Existing Conditions}

One-room stone kitchens built in 1853 were occupied as officers' quarters with the onset of winter. In 1856 Lieutenant S. B. Holabird stated that additions had been made to the seven oneroom kitchens to convert them to officers' quarters. Rooms added during the remaining pre-Civil War years and the early post-Civil War occupation (1868-1872) expanded the quarters into their current configurations (Texas Parks and Wildlife Department 1975:149, 235), including the two kitchens that eventually became part of a single building, Officers' Quarters 1. Officers' Quarters 2-6 encompassed the other five one-room kitchens.

By 1856 Colonel J. K. F. Mansfield reported that the "officers were well quartered in stone buildings \& shingled roofs" (Crimmins 1939:364). His 1856 plan of Fort McKavett shows five officers' quarters in the locations of Officers' Quarters 2-6 (although with differing plans), four additional officers' quarters in the vicinity of the old hospital (one building), the later commanding officer's quarters (this building is marked "new off. qtrs."), and two buildings west of the parade ground (Crimmins 1939:366). Differences between this plan and known building locations and shapes indicate that the plan is more schematic than exact.

During Mansfield's inspection, there were five officers and one assistant surgeon stationed at the post who may have been quartered in the officers' quarters (three other officers were on leave or stationed on temporary duty elsewhere), indicating possibly one officer (plus family and servants/ orderlies) per building for the total assigned complement. The most likely occupants included one officer of Company C, 1st Infantry, and two officers of Company E, 1st Infantry (Crimmins 1939:361). The commanding officer's quarters was completed shortly afterward in 1857-1858, and in 1857 Lieutenant S. B. Holabird noted that the assistant surgeon occupied one of the officers' quarters west of the parade ground (Texas Parks and Wildlife Department 1975:223, 235).

The officers' quarters south of the parade ground were described in 1875 as having low floors and canvas ceilings (Sharpe and Horton 1875). The row of four officers' quarters (Officers' Quarters 7-10) on the east side of the secondary parade ground between the commanding officer's quarters and the headquarters was built during the 1868-1872 post-Civil War rebuilding period. These buildings are shown on a ca. 1871 map (Figure 10) in Texas Parks and Wildlife Department (1975:158) and Black and Ing (1980:32). In 1875 there were

four captains' quarters, all of stone; each is 36 by 15 feet, one story, comprising two rooms, and an L, 15 by 16 feet, containing one room; a veranda extends the whole length in front. One of these quarters has a kitchen, 15 by 12 feet; the others have no kitchens. The plan of these quarters, had they all of them kitchens, would be excellent, but they are built of uneven and mis-shaped stones, of the most varied sizes, all put up in the utmost confusion as to making any joints; the walls not pointed and the mortar inferior and subject to washing out by rains. Two out of three fires in each 


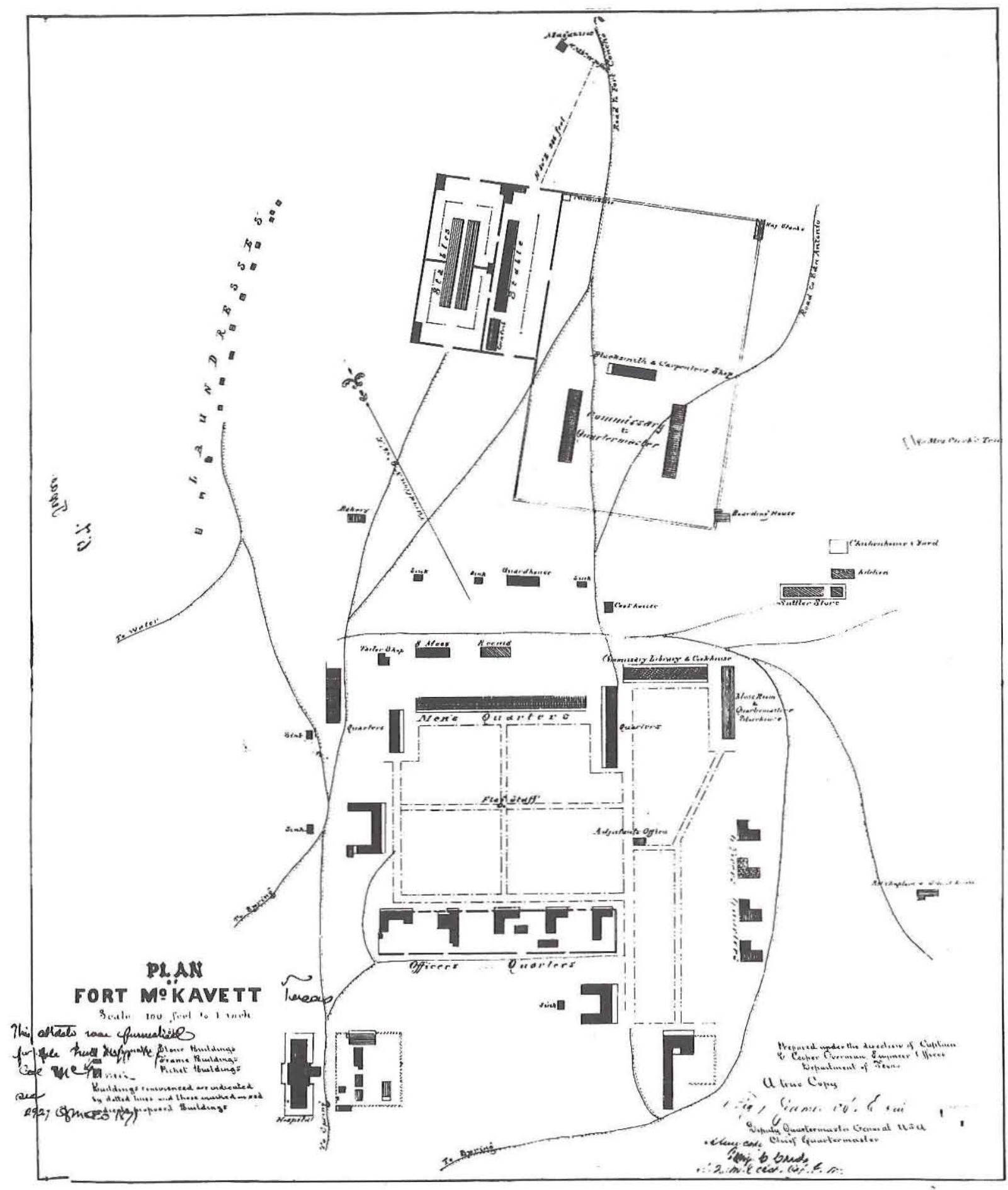

Figure 10. Plan of Fort McKavett, ca. 1871 (Black and Ing 1980:32; Texas Parks and Wildlife Department 1975:158). 
smoke so badly when the winds blow, which they do nearly daily in the latter part of fall, the entire winter, and early spring, that the occupants are well-nigh blindfolded [sic] whenever fires are made in them. These fire-places are all small. The quartermasters received stoves during the year sufficient to give one to each of these quarters.

‥

The officers' quarters are, with the exception of the commanding officer's quarters, restricted to the literal requirements of the Regulations, with no conveniences whatever that are found at many military posts in the way of attics or basements. But three of the lieutenants' quarters have any outbuildings, such as wood-sheds or shelters of any kind. With but few exceptions there are no closets and but few shelves, which would take the place of wardrobes, cupboards, etc. [Sharpe and Horton 1875].

These buildings are shown on an 1874 map (Figure 11 ) in Sharpe and Horton (1875) and Texas Parks and Wildlife Department (1969); on an 1875 map (Figure 12) in Black and Ing (1980:35), Texas Parks and Wildlife Department (1975:161), and Sullivan (1981:42); and on an 1876 map (Figure 13) in Green (1969).

With the closing of the post in 1883, the military buildings became the core of the town of Fort McKavett. Three officers' quarters (Officers' Quarters 4-6) were owned by the Bihl family by 1909 and remained in the family's ownership until acquisition by TPWD in 1975. At that time, Officers' Quarters 6, 8, 9, and 10 were all L-shaped structures being maintained as private residences. Officers' Quarters 2 and 3 also were occupied as residences. As of 1975, Officers' Quarters 5 was unoccupied and deteriorating rapidly, and Officers' Quarters 1, 4, 7, and 11 were in ruins (Texas Parks and Wildlife Department 1975:235-236).

\section{Officers' Quarters 1}

Officers' Quarters 1 is on the west side of the main parade ground between Officers' Quarters 2 in the southwest corner and Barracks 2 in the northwest corner. This structure is U-shaped with eight to nine rooms.

\section{History}

This officers' quarters originally consisted of two separate kitchens-Rooms 1 and 5-that eventually became part of a single building, probably in three steps (first, Rooms 1 and 5; second, Rooms 2 and 4; and third, Room 3), with the back wings added in either the second or third step. The 1875 Surgeon General's report (Sharpe and Horton 1875) describes a $98-\mathrm{x}-15$-ft stone building with an ell at each end, a full-length veranda in front, and eight rooms for four lieutenants (two married and two single) that probably represents Officers' Quarters 1. This quarters was described as having good fireplaces (Sharpe and Horton 1875).

The ca. 1871 map of Fort McKavett (see Figure 10) shows the front porch, the stone sink, and a frame addition on the west end of the south wing. The 1874 map (see Figure 11) indicates nine rooms in the building, with five along the front and two in each back wing. A porch was present along the front, a small two-room structure was behind the main wing in the courtyard, and a frame sink or latrine was at the back of a walled back yard. The 1875 map (see Figure 12) indicates a four-bay front porch with steps on the north and south ends, the small two-room structure, a frame sink in the walled back yard, and additions to the main structure consisting of a frame room on the north side of the west end of the south wing, a stone room on the west end of the west wing, and a stone room on the center of the south side of the north wing. Both maps indicate that the two-room structure consists of a north room of stone and a south room of wood construction. The 1876 map (see Figure 13) shows a four-bay front porch, a stone two-room structure in the courtyard, the frame sink in the walled back yard, and the stone additions on the west end of the north side of the south wing and on the center of the south side of the north wing. The 1876 map does not show room divisions.

The 1874 map indicates nine rooms (possibly including additions shown on later maps), and the 1875 Surgeon General's report describes eight rooms. All maps and the 1875 Surgeon General's 


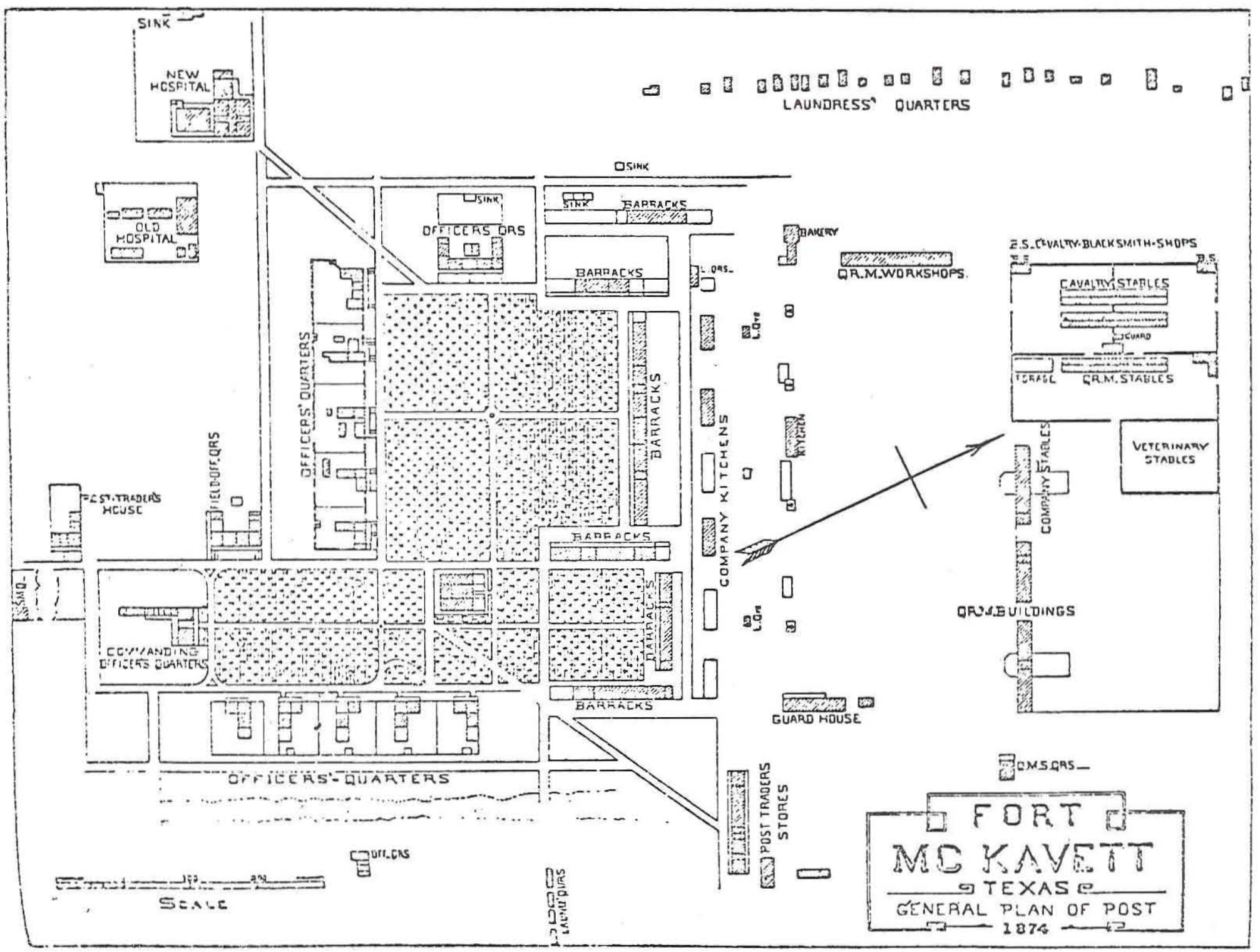

Figure 11. Fort McKavett, Texas, General Plan of Post, 1874 (Sharpe and Horton 1875; Texas Parks and Wildlife Department 1969). 


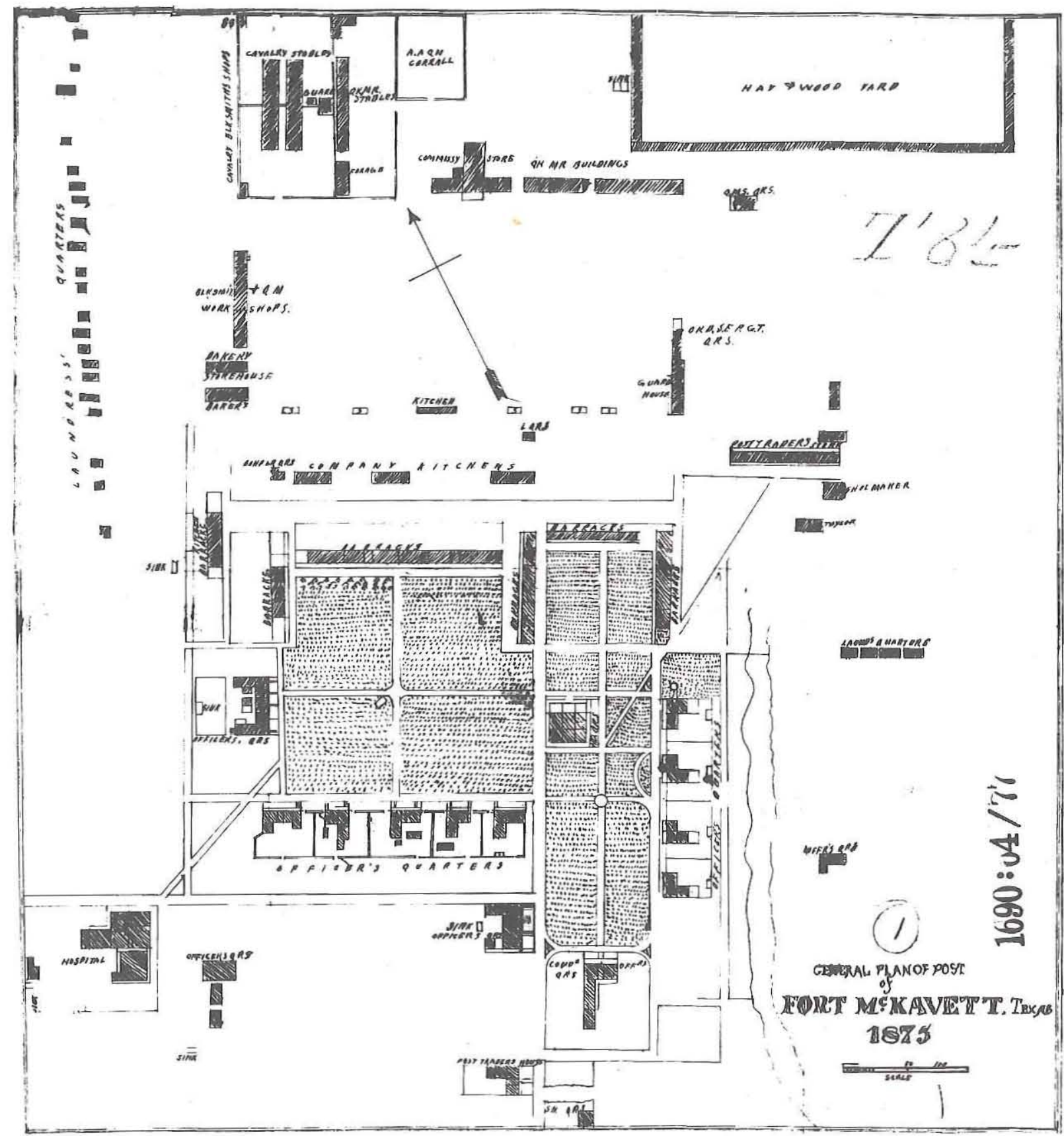

Figure 12. General Plan of Post of Fort McKavett, Texas, 1875 (Black and Ing 1980:35; Sullivan 1981:42; Texas Parks and Wildlife Department 1975:161).

description show the front porch. All except the ca. 1871 map show the two-room structure, with the 1874 and 1875 maps indicating a stone room on the north and a frame room on the south, and the 1876 map indicating two stone rooms. All except the ca. 1871 map show the sink as frame construction and show the wall enclosing the sink and back yard. The 1875 and 1876 maps show an addition on the north side of the west end of the south wing, but the 1875 map shows the addition as frame and the 1876 map shows it as stone. The 1871 map shows this as a frame addition not directly connected to the wing, and the 1875 map shows a stone addition, possibly a sink, on the 


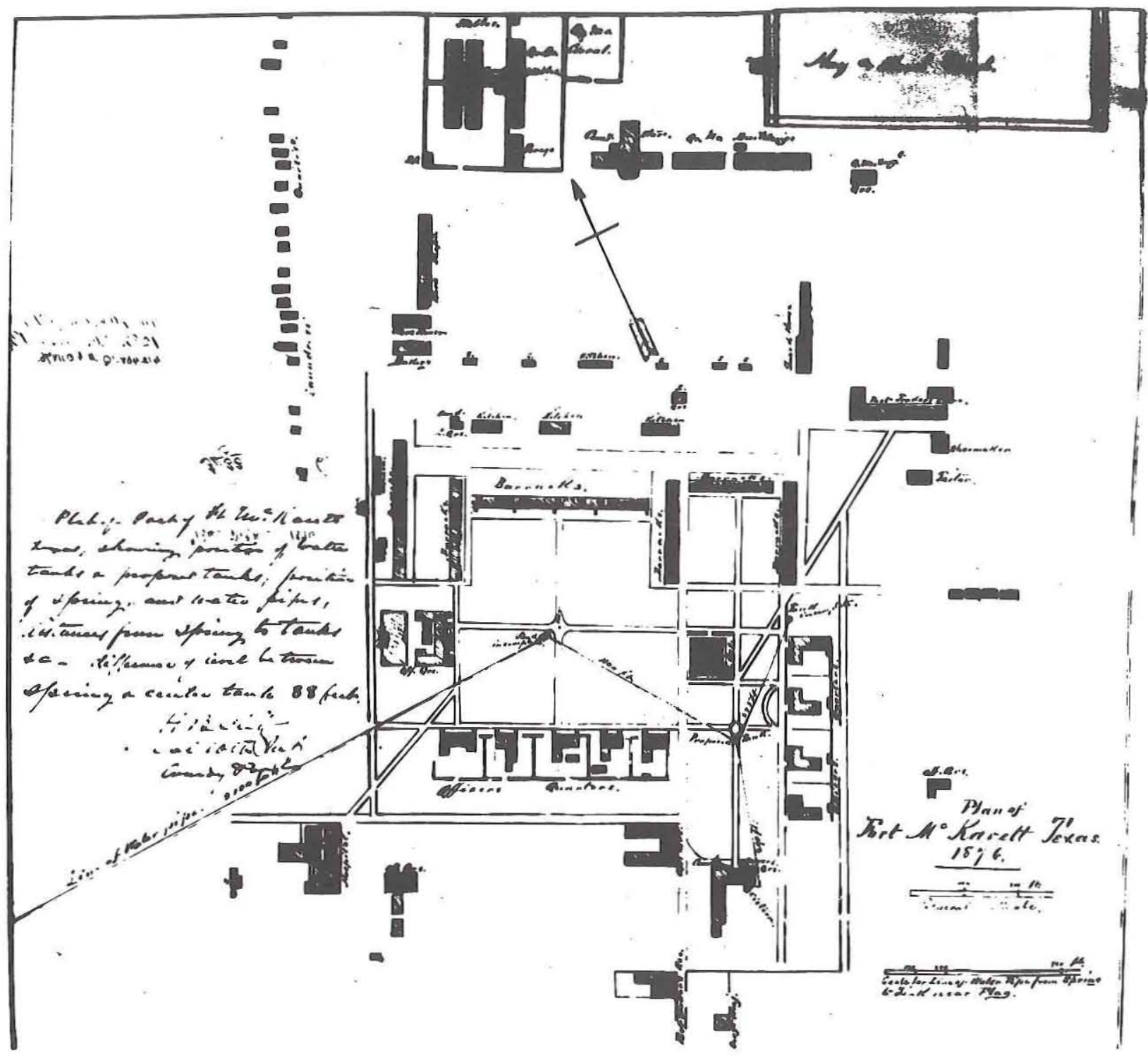

Figure 13. Plan of Fort McKavett, Texas, 1876 (Green 1969).

west end of the south wing. The 1875 and 1876 maps both show the stone addition on the center of the south side of the north wing.

It is likely that keys for building material types were not used consistently or accurately on these maps since most probably were not created in the field or field checked. Some of the differences between maps may reflect on-the-ground differences at the time the maps were made. The maps provide relatively reliable evidence for a porch on the front of this quarters, a two-roomed structure in the courtyard, a sink inside a walled back yard, and additions on the south side of the north wing and the west end of the south wing. No historical photographs of this quarters are available, reflecting its isolated location relative to buildings occupied by civilians and the fact that the building was destroyed by fire either late in the military occupation or early in the civilian occupation.

When TPWD acquired the fort property in 1975 , Officers' Quarters 1 was a ruin with only the wall lines discernible in some areas (Texas Parks and Wildlife Department 1975:235). The east half of the ruin was acquired by the state. Archeological excavations in Rooms 1, 4, and 5 and wall clearing in the west wall of Room 2 took place in 
the fall of 1978 and the fall of 1980 (Figure 14).

\section{Archeological Results}

Wall lines were exposed to determine locations of doors, windows, and fireplaces and details of these architectural features. Excavation indicated that the structure burned. Much of the sediment above the wall foundations had been disturbed by activity associated with a trash pile established east of the fenceline through the center of this structure west of Rooms 1 and 5 .

\section{ROOM 1}

Wall widths usually were 1.9-2.1 $\mathrm{ft}$, but the southwest and northwest corners were approximately $3.5 \mathrm{ft}$ wide. The west wall and northwest corner were disturbed.

A 2-x-2-ft unit over the south doorway and a $1-\mathrm{x}-3.5-\mathrm{ft}$ unit just inside the room were excavated in 1978 to expose the doorway, to locate hardware, and to search for remains of the original sill and flooring. The south doorway was defined by plaster lines from a former vertical door frame with a metal hinge on the east side. The top layer in the interior unit consisted of brown loam $0.1-0.6 \mathrm{ft}$ thick with roots and occasional large to medium rocks $0.4-0.9 \mathrm{ft}$ in diameter and recent artifacts representing topsoil and wall fall. The second layer was sandy deteriorated red, yellow, to grayish white mortar $0.1-0.2 \mathrm{ft}$ thick containing occasional charcoal fragments. The third layer consisted of charcoal and burned floorboards containing cut nails and decomposed metal fragments. Layers 2 and 3 contained plaster, some whitewashed and some painted rust pink. Burned cane or grass was found in the third layer, possibly reflecting hay storage. The south doorway was reexcavated in 1980 with a $1-x-5.5-f t$ unit. A hinge was found on the west side of the doorway. Sheet

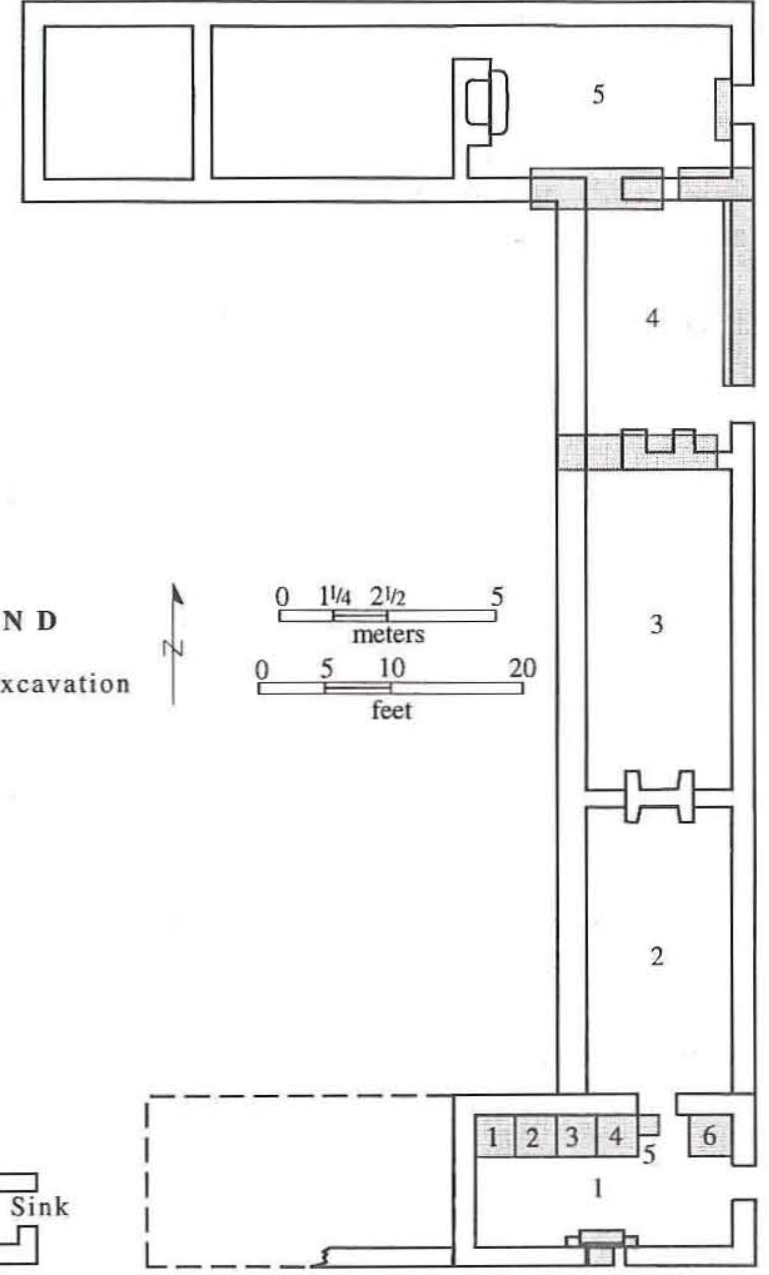

Plan of Officers' Quarters 1.

metal was found in this area and may represent flashing used to line the roof valleys formed where the roofs of the main wing and back wings join.

Six 3-x-3-ft units were established along the north wall to search for floor remnants, and all were excavated completely except for Unit 5, of which only $1.4 \times 1.34 \mathrm{ft}$ in the northwest corner was excavated. Units 1 and 2 had layers of ash just below the surface, where the floor had burned. Unit 3 was thought to be beneath a window, and sediments were dry screened through $1 / 4$-inch mesh and fine screen. The top layer was a thick root zone with dark brown sediment. The second layer was abundant mortar and painted plaster wall fall $0.45 \mathrm{ft}$ thick with ash and charcoal. The third layer was very dark ashy sediment $0.15 \mathrm{ft}$ thick containing charcoal, burned boards (including one 
measuring $7 / 16$ inch thick and $5 \% 16$ inches wide), and sheet metal, the latter possibly flashing from the roof. Below the ash and charcoal was a soft black powder $0.07 \mathrm{ft}$ thick overlying an orange and yellow surface possibly representing the surface exposed when the building burned. A butt hinge was found in the northwest corner of the test in the plaster layer. A charred board originating in the ash and charcoal layer and oriented east-west in the north end of Unit 5 underlay a hinge near the north wall.

\section{ROOM 4}

The north $14 \mathrm{ft}$ of the east wall of this room was excavated to examine construction details, particularly the construction sequence of Rooms 4 and 5. The foundation was usually capped by a thin layer of decomposed/cemented mortar and consisted of large angular rocks forming an undulating surface. This construction differed from the mix of large cornerstones and small stones forming a level surface in the deeper Room 5 foundation and indicates that the two rooms were built at different times. The Room 4 foundation also was built differently from that of Room 3 to the south. The mortar in Room 3 was white and hard, but the mortar in the south wall of Room 4 was pink and much softer. The Room 3 walls also abut onto the south wall of Room 4.

The unit along the east wall varied from 2.1-2.6 $\mathrm{ft}$ wide; sediments above the foundation were disturbed and were not screened. The topsoil was a brown loam root zone with small rocks and recent artifacts. Beneath was a layer of loamy ash, decomposed mortar, and plaster.

The west wall of this room was $22.15 \mathrm{ft}$ long. The top intact layer was compact mortar and plaster fall overlying the foundation.

Excavation within a $2.75-\mathrm{x}-12-\mathrm{ft}$ area in the south end of the room exposed details of the fireplace in the south wall and doorways in the west end of the south wall and the south end of the east wall. The room is $15.4 \mathrm{ft}$ wide on the south end. The fireplace was offset slightly to the east of center in the south wall and was relatively wide, $3.15 \mathrm{ft}$. Doorways were identified on the basis of charcoal on the foundation marking the presence of burned doorsills. To the west of the fireplace, charred floorboards running north-south were in situ beneath approximately $0.8 \mathrm{ft}$ of building debris. Above the random-width $(61 / 4-71 / 2$-inchwide) tongue-in-groove floorboards was approximately $0.1 \mathrm{ft}$ of churned charcoal probably representing burned ceiling and roofing materials.

\section{ROOM 5}

Architectural details of the south and east walls of this room were examined through three excavation units. A $2.5-\mathrm{x}-6-\mathrm{ft}$ unit on the east end of the south wall was placed to search for architectural features and associated artifacts. A burned wooden joist oriented east-west and $4 \mathrm{ft}$ long, terminating at the door at the west end of the south wall, was adjacent to the wall (see below). Painted plaster was associated with the wood. The south wall foundation was constructed of a combination of large cornerstones and small rocks $0.4-0.7 \mathrm{ft}$ in diameter. Original mortar was found on top of the foundation, which formed a level surface. Above the foundation was a fine brown sediment, with disturbed sediments overlying this.

The top layer in the unit on the east end of the south wall was a brown loam root zone with rocks $0.1-0.2 \mathrm{ft}$ thick. Dark gray ash $0.1-0.25 \mathrm{ft}$ thick occurred below in an irregular lens. The third layer was decomposed mortar and plaster in brown sandy loam. Cemented mortar occurred in the rock wall foundations and associated burned wooden floorboards. The mortar and plaster layers produced cut nails, metal and pearl buttons, a brass door key, window glass sherds, and whitewashed and rust-pink plaster, some with alternating white and pink layers and some blackened from soot and the fire that destroyed the building.

A $1.5-\mathrm{x}-4.5-\mathrm{ft}$ unit was placed inside the center of the east wall to search for a doorsill and possibly associated hardware and flooring. Burned wood remnants of the doorsill were found overlying floorboards, and a hinge was found on the south side of the doorway. The top layer was a brown loam root zone $0.4-0.6 \mathrm{ft}$ thick with large and small rocks, recent artifacts, and small concentrations of ash. The second layer was decomposed mortar and plaster $0.1-0.35 \mathrm{ft}$ thick with occasional ash. The third layer was brown sandy loam $0.1-0.2 \mathrm{ft}$ thick with ash and frequent charcoal from roof fall. Artifacts associated with the eastwest-oriented floorboards and roof fall included cut nails, a blue bead, a burned pearl button, and porcelain doll fragments. 
A 3-x-10-ft area of the south wall was excavated to search for architectural details. A compact layer of mortar and plaster fall overlay the doorway. The floorboards on the west side of the doorway were best preserved, measured 5-7 inches in width, and lay unevenly as though collapsed onto an uneven surface of the dirt floor beneath. Only a small section of doorsill with grain oriented perpendicular to the floorboards was preserved. All along the south wall were plaster fragments with a peach- to rust- to rose-colored paint. A few fragments had three layers, an undercoat of whitewash, the rust paint, and then a gray to black which represents soot-covered whitewash.

\section{Officers' Quarters 2}

Officers' Quarters 2 is the westernmost in the line of five officers' quarters along the south side of the main parade ground. This U-shaped building has five rooms.

\section{History}

This duplex was described in 1875 (Sharpe and Horton 1875) as a one-story 61-x-15-ft building with $21-\mathrm{x}-13-\mathrm{ft}$ and $15-\mathrm{x}-19-\mathrm{ft}$ ells at each end. The building contained five rooms occupied by one married and one single lieutenant. In the rear was a frame kitchen containing two small rooms. Acting quartermaster Lieutenant S. B. Holabird referred to this building in 1857 as Captain Prince's quarters and described the room-building sequence. The east room with a fireplace was built in 1853, and the first kitchen was added onto the south end of this room with the double fireplace in early 1857 . The north-central room was added between 1854 and 1857, and the northwest corner room was completed as the second kitchen in late 1857. The fireplace on the east end of this corner room was remodeled from a doorway in 1858/1859 or $1869 / 1870$. The southwest room was added on between 1868 and 1870 .

The ca. 1871 map of Fort McKavett shows a stone building with a stone outbuilding, probably a sink, against the west wall of the back yard (see Figure 10). The 1874 map shows this building divided into four rooms, with entrance steps on each end of the front porch and a possible sink in the corner of the west wall of the back yard (see Figure 11). No additional data are visible on the
1875 map (see Figure 12). The 1876 map shows the quarters divided into two parts, with the east wing separated from the remainder of the building (see Figure 13). All maps show the pathway along the west side of the main parade ground leading from Barracks 2 in front of Officers' Quarters 1 to the center of Officers' Quarters 2.

A 1912 photograph of the fort from the Commanding Officer's Quarters (Figure 15) shows the back yard, particularly the end chimney on the east wing, the windmill and tank behind this wing, a stone and wood fence between this quarters and Officers' Quarters 3 to the east, and a wood-frame garage in the southeast corner of the back yard wall accessed from the road along the back walls of this row of officers' quarters. In addition, an end chimney is present on the west wing; this chimney does not correspond with existing conditions when the fort property was acquired.

A 1936 Historic American Buildings Survey (HABS) photograph of the row of officers' quarters on the south side of the main parade ground shows Officers' Quarters 2 with its end chimney on the east wing and ridgeline chimney in the main wing. A wood fence separates the quarters from the parade ground.

When the state acquired the fort property in 1975, Officers' Quarters 2 was being occupied as a residence with some interior modifications since the military occupation (Texas Parks and Wildlife Department 1975:235). A sink that had been mortared on the interior and used as a tank for the windmill in this yard was still standing against the back wall and directly behind the east wing. Archeological work in the front yard and adjacent to the back wings took place in 1978 (Figure 16).

\section{Archeological Results}

Two-ft-wide trenches were excavated in the front yard of this quarters to search for walkways. One of these, a 2-x-8-ft north-south unit, was placed adjacent to the concrete-slab front porch and several feet east of the four slabs forming a walkway to the front steps near the center of the porch. As exposed at $0.35 \mathrm{ft}$ below the surface, the sediments in the southern $3.4 \mathrm{ft}$ of the trench adjacent to the existing porch were a very dark grayish brown clay loam, while the sediments in the northern part of the trench were a dark grayish brown gravelly loam. This change may mark the 


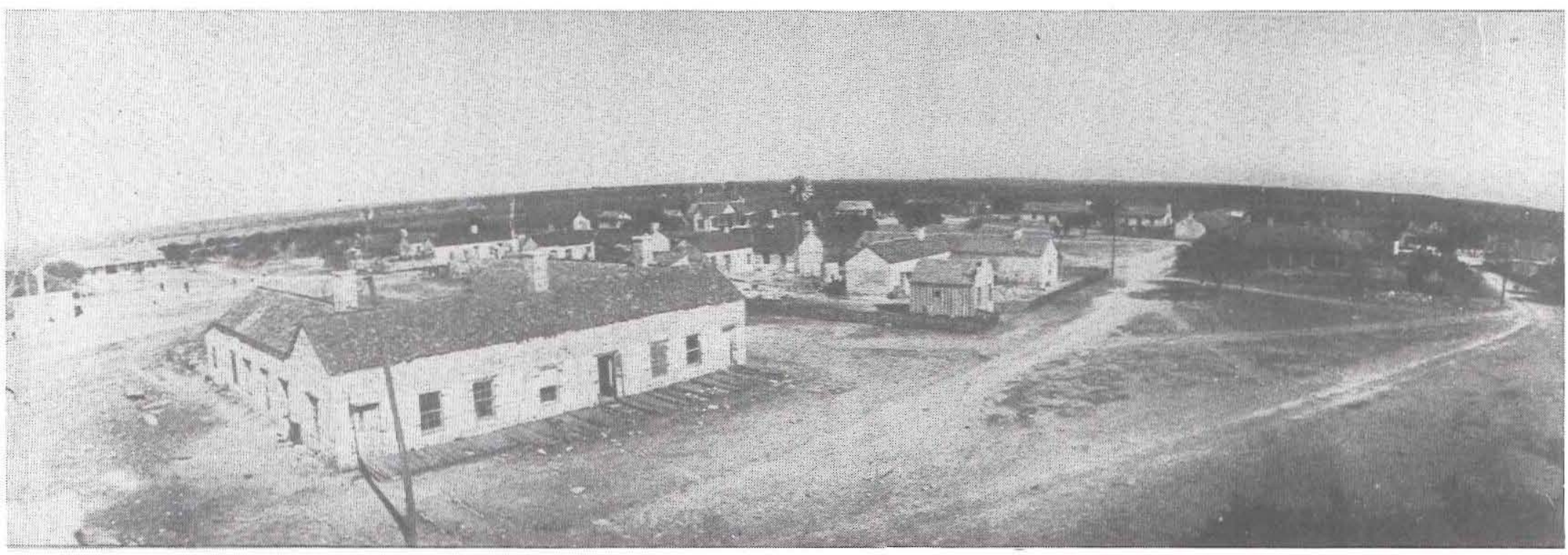

Figure 15. Photograph of Fort McKavett taken in 1912 from the roof of the Commanding Officer's Quarters; view is to the north, with Officers' Quarters 11 in the left foreground (Texas Parks and Wildlife Department 1975:199). 


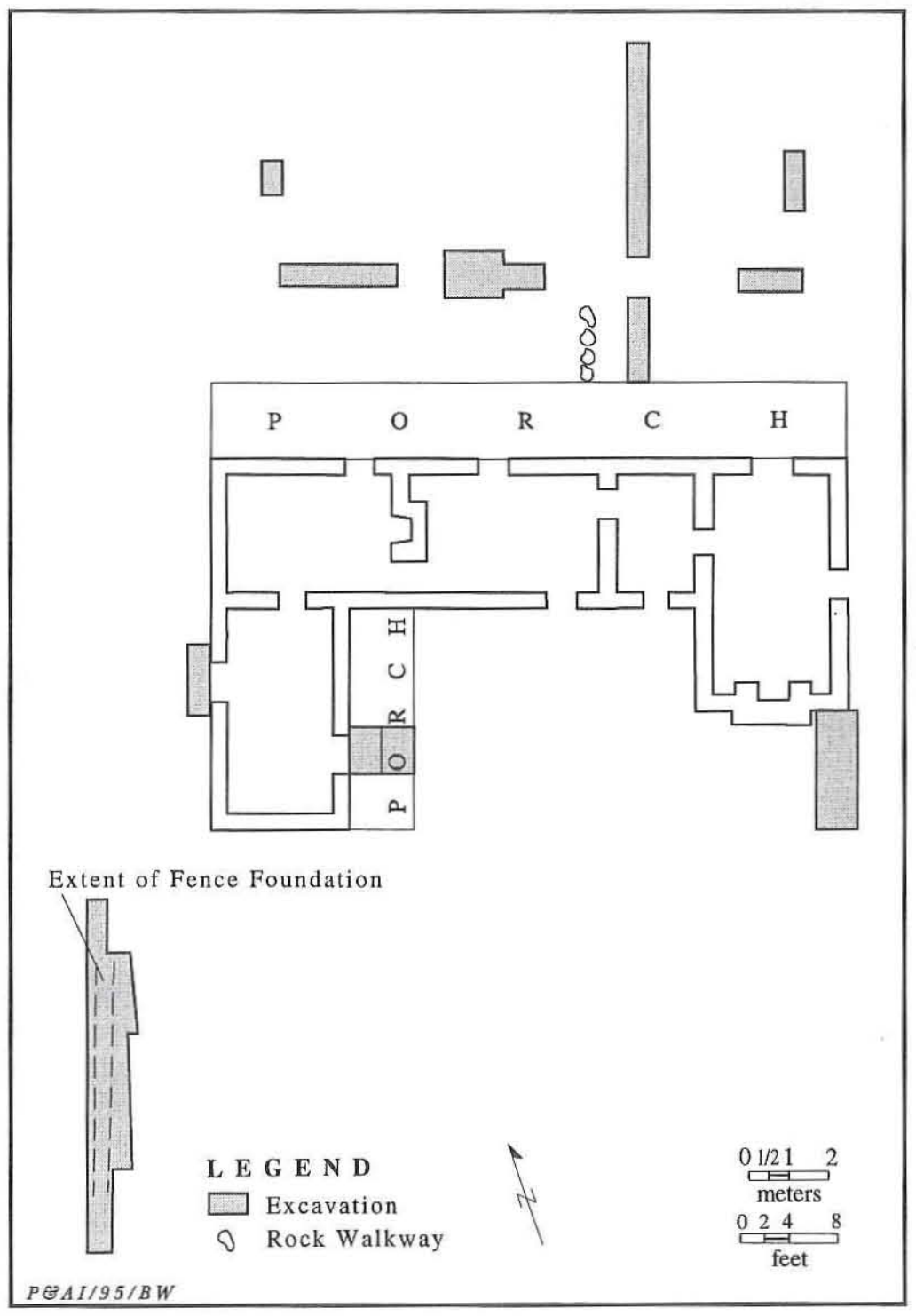

Figure 16. Plan of Officers' Quarters 2.

original porch line. Bedrock occurred at $0.5-0.65 \mathrm{ft}$ below the surface.

The sediment with scattered gravel continued north into the southern $7 \mathrm{ft}$ of a $2-\mathrm{x}-18-\mathrm{ft}$ trench $3 \mathrm{ft}$ north of the porch trench and east into a 2-x-6-ft trench perpendicular to the porch trenches (see Figure 16). The gravel in the eastern trench was 5 inches below the surface and 3 inches above bedrock. The five different sediments encountered in this long trench may be associated with introduced fill at the edge of the front fence from use as a front driveway or from use of the parade ground. The gravels could represent the lining of a walkway leading to Officers' Quarters 3 to the east or to the side yard of Officers' Quarters 2.

Four units were excavated in the back yard (see Figure 16). Two adjacent units measuring $3.9 \times 2.7 \mathrm{ft}$ were excavated adjacent to the east doorway of the west wing room to search for a military-period porch. A 4-x-7-ft area of floorboards was removed from the existing porch, and four north-south floor joists were exposed. Three of the joists were milled lumber, and one was rough cut. The joists were placed at 3-ft intervals on limestone blocks, with one odd joist placed on the old doorsill. The south $0.45 \mathrm{ft}$ of the easternmost joist in the eastern unit was overlapped with another joist to form continuous support. Approximately $0.75 \mathrm{ft}$ north of the southeast corner of the eastern unit, a large square stone set in clay loam supported the porch wall. Another spaced stone support without a joist was $1.8 \mathrm{ft}$ east of the eastern joist in this unit.

The deposits in this unit were loose grayish brown sediments that had filtered through the boards and were underlain by compact dark brown clay loam grading into very dark brown clay loam with bedrock $2-5$ inches below the clay loam. The joists were excavated into the dark brown clay loam. Artifacts in the unit next to the door date to the nineteenth and twentieth centuries and include window and bottle glass fragments, buttons, cut nails, crown bottle caps, tacks, eye bolts, cuprous and ferrous straight pins, a 1944D one-cent coin, lead sinkers, match sticks, and rubber washers. The porch materials and artifacts primarily are post-military in date.

One unit was excavated back of the fireplace in the east wing to search for the kitchen reported to exist to the south in 1854-1857. This approximately 10 -ft-long unit was placed in the southeast outside corner of the east wing in a search for the 
east wall (see Figure 16). No wall line was found; however, mortar and plaster fragments and a few artifacts, including a ferrous door hook, porcelain, and glass at $0.2 \mathrm{ft}$ below the surface, may be remnants of a former room. Bedrock in this area occurred at $0.5 \mathrm{ft}$ below the surface.

A 2-x-6-ft unit was excavated outside the west doorway of the west wing. The doorway was $3.8 \mathrm{ft}$ wide, and the threshold stone was $3.26 \times 0.9 \mathrm{ft}$. The stone appeared to be set in the original ground surface consisting of black clay approximately $0.5 \mathrm{ft}$ thick. Depth to bedrock gravel was $1-1.15 \mathrm{ft}$.

A 29-ft-long section of the foundation of the west back yard fence $14 \mathrm{ft}$ south and $9 \mathrm{ft}$ west of the southwest corner of the quarters was excavated and mapped. The foundation ranges from $1.5-2.0 \mathrm{ft}$ wide and was constructed with rock rubble and pink mortar, the latter probably from granitic sand from the Llano River drainage. There was no evidence of the possible sink built into the corner of this wall as shown on the ca. 1871 and 1874 maps (see Figures 10 and 11).

\section{Officers' Quarters 4}

Officers' Quarters 4 is the central building in the row of officers' quarters south of the main parade ground. The structure is L-shaped with four rooms.

\section{History}

This structure was occupied as officers' quarters during the pre-Civil War military occupation. In 1853 the officers lived in a $12-\mathrm{x}-20-\mathrm{ft}$ room (Room 0 ) originally designated as a kitchen. During the rebuilding program of 1868-1872, these quarters were repaired and reoccupied (Texas Parks and Wildlife Department 1975:235).

The 1874 map of Fort McKavett shows the quarters as divided into four rooms (see Figure 11). The 1876 map shows the building as divided into two wings, Rooms 0 and 1 on the west and Rooms 2 and 3 on the east, with two sets of front steps corresponding one with each wing (see Figure 13). The ca. 1871, 1874, 1875, and 1876 maps (see Figures 10-13) show the wood-framed kitchen east of Room 1 and the latrine south of Room 1 (although the latter is pictured near the back wall of Room 1 rather than adjacent to the back wall of the quarters as the archeological work indicated). An 1875 U.S. Army Surgeon General's report (Sharpe and Horton 1875) describes an officer's quarters that may represent this building based on the presence of a wood-framed kitchen. The stone building is described as $48 \times 15 \mathrm{ft}$ with a 31-x-15-ft ell and containing four rooms for the post surgeon and one lieutenant, both married.

An enlargement of a ca. 1912 photograph of Fort McKavett taken from the roof of the commanding officer's quarters (see Figure 15) shows what appears to be a shadow in the side yard, but the wood-framed kitchen does not appear to be standing at this time. A different photograph dating to 1911 shows the partially collapsed west wall of the Room 0 front porch enclosed to form a room on the west front of the building and the adjacent west front stone wall (Figure 17).

A 1936 HABS photograph showing this building from the northeast shows the east end of Room 3 with its fireplace, the wood rail fence extending from the east end of the porch toward Officers' Quarters 5, and additional wood fences enclosing the side yard into what appears to be a corral separating Officers' Quarters 4 and 5.

The building was occupied by civilians from the late nineteenth century until its abandonment in the twentieth century. The structure was in ruin when TPWD acquired it. Only part of the east wall and the Room 3 end chimney were standing, although the remaining limestone wall remnants outlined the overall form of the building (Texas Parks and Wildlife Department 1975:242).

Extensive archeological work (Figure 18) took place in the summer of 1978 , fall of 1979 , spring of 1982, spring of 1984, spring of 1985, and in 1990. The four interior rooms were excavated almost completely, the latrine against the back wall was excavated, and part of the south or back yard between the back wall of Room 1 and the latrine was mapped. The east or kitchen yard of the structure was excavated in a combination of checkerboard and contiguous exposures to define the area of the wood-framed kitchen. Units in the footprint of the reconstructed front porch were excavated. In addition, alternating units along the outside of the walls on the north and west sides of the structures were excavated, and units were excavated between Officers' Quarters 4 and 5 to search for the wall that the 1875 map (see Figure 12) shows once separated the yards of these two 


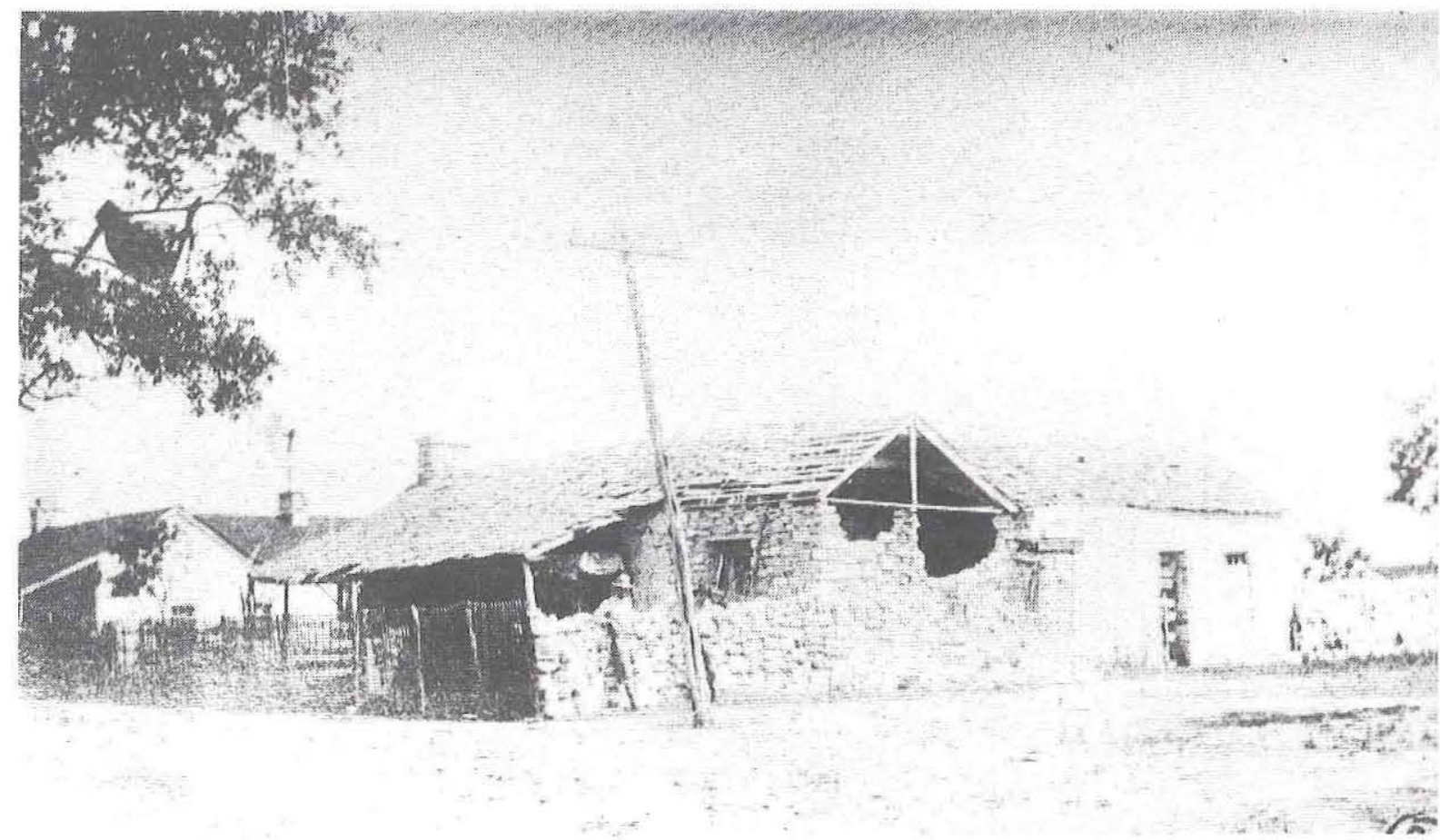

Figure 17. Photograph taken in 1911 of unoccupied Officers' Quarters 4; view is to the south (Texas Parks and Wildlife Department 1975:237, courtesy of Lyndsay W. Phillips).

buildings. Trenches north and northeast of the east wall of Room 3 were placed in the front yard to examine the east-west road and two fences (one fragmentary fenceline based on archeological evidence) bordering the south end of the parade ground along the front of the building.

\section{Archeological Results}

\section{ROOM 0}

Room 0 , originally designated Room 1 , was the first room built; it was intended as a kitchen but was occupied as an officers' quarters instead. The limestone rubble walls of this room, with the rubble placed flush on the outside of a wide foundation forming an interior ledge, probably supported a wood floor, but there is no archeological evidence that one was present. Doors were cut into the south wall to allow access to Room 1. In the vicinity of the front door, the undersill rocks were laid directly on the basal black clay, and a lens of mortar occurred at the contact between the top and second layers $1 \mathrm{ft}$ from this door.

Excavation of the twenty-four 3-x-3-ft units in this room to Level 2 showed narrow shallow trenches along the north, east, and west walls. These shallow trenches no more than $0.4 \mathrm{ft}$ wide occurred in intermittent fashion along all nonfireplace walls. The basal layer of black clay occurred at higher elevations in a $6-\mathrm{ft}$ circular area in the center of the room, indicating either that less excavation was done in the center of the room than along the walls during construction or that black clay from the original ground surface was trenched slightly to set the walls and the backdirt was thrown into the center of the room. A depression occurred in the northeast corner of the room. Concentrations of deteriorated mortar occurred along the walls and appeared to have washed out between wall stones.

Flagstone and mortar extensions east and west from the fireplace are the remnants of the original south wall of this room; the south wall was torn down and remodeled into a doorway on the west side of the fireplace and into a cupboard on the east side of the fireplace leading from Room 0 to Room 1. The Room 1 fireplace addition was made symmetrical with the original Room 0 fireplace except that the underfire was lined with flagstones on its south side. The double fireplace configuration is $7.5 \mathrm{ft}$ wide from the outer edges of the 


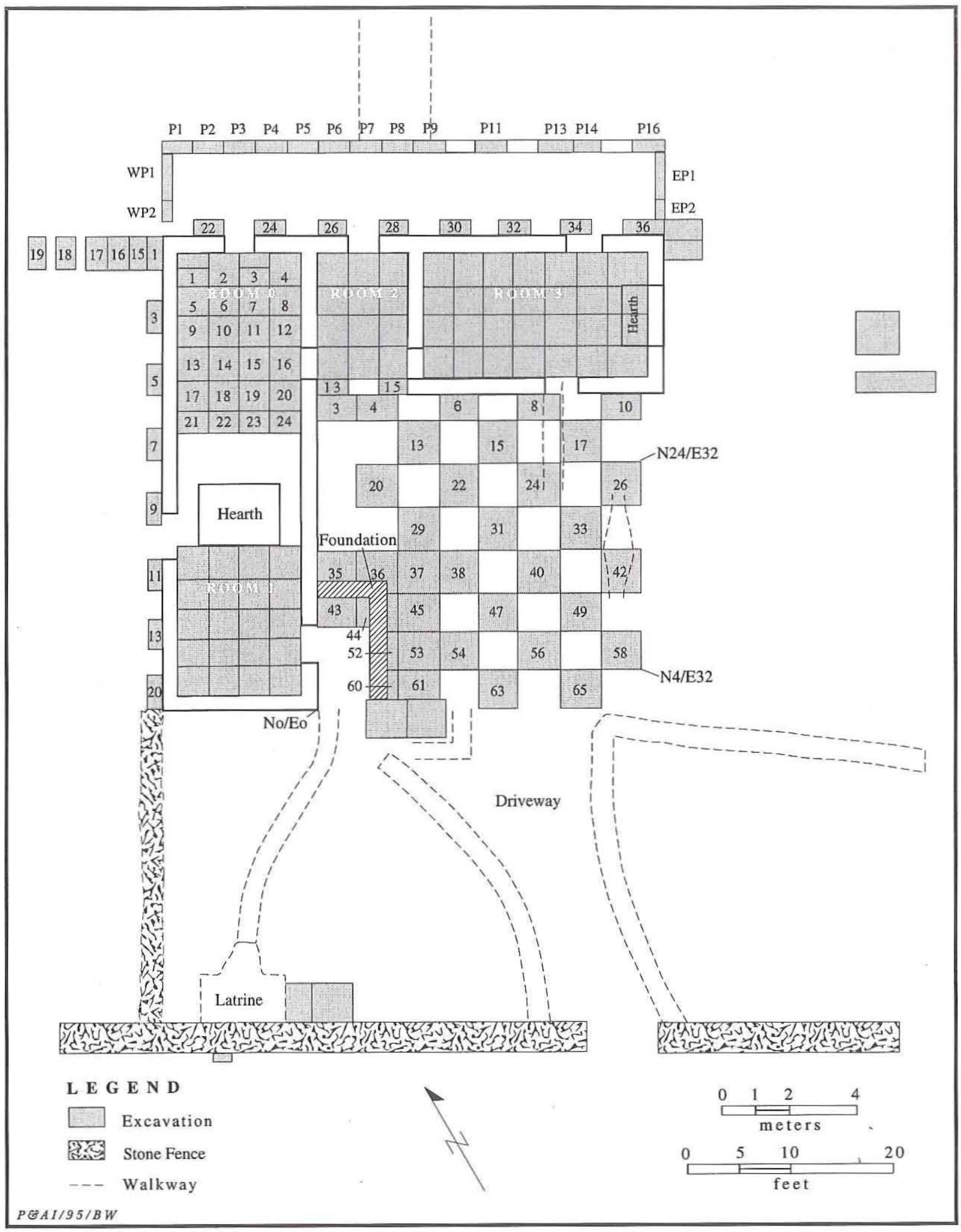

Figure 18. Plan of Officers' Quarters 4. 
coving and $6 \mathrm{ft}$ deep from Room 0 to the Room 1 underfire edge. Mortar concentrations showed where flagstones had been robbed from the underfire and coving areas and where remnants of the original wall separate the two sides of the fireplace. The east side of the fireplace appears to have been dismantled more than the west side.

The top layer in the fireplace vicinity consisted of loose fill. This layer contained large metal pieces, primarily horseshoes and door and window hardware. Fireplace strata dating to the feature's use were packed gray to brown sediments containing ash and large pieces of gravel, a layer of ash fill with some charcoal, and a layer of rubble spalls and ash. The latter layer dates to room construction or remodeling. Small pieces of burned limestone occurred near the underfire. Fireplace and wall foundation stones were set into the basal layer of black clay loam forming the original ground surface.

A cross-shaped balk consisting of six northsouth units (Units 2, 6, 10,14, 18, and 22) and four east-west units (Units 5, 6, 7, and 8) was profiled. Five strata were present in most of the profiles. The top layer was a noncompact to moderately compact light brown to brownish gray silt to clayey silt and eolian sand containing some angular wall rubble fragments, mortar, and grass roots representing topsoil, wall fall, and eolian deposition. This top layer was not present in the south balk profiles of Units 7 and 8.

The second layer of unconsolidated to compact tan to light gray to grayish brown friable mortarrich sandy loam with many limestone cobbles and fist-sized fragments represents primary wall fall (Figure 19). This zone tended to contain relatively frequent artifacts and also was relatively disturbed. Mortar occurred in greater densities within $1 \mathrm{ft}$ of the walls. In the Unit 2 east and Units 7 and 8 north profiles, the first and second layers were not observed as separate zones. In the Unit 22 east balk profile (see Figure 19), this layer is heavily mottled with the underlying red layer and disturbed by rodent burrowing.

The third layer was a compact brownish red to reddish to orangish brown clay loam to silt with moderate amounts of rounded stream gravels, few artifacts, and less disturbance than the wall fall layer above. The clay indicates that this layer was derived from the original ground surface, perhaps as backfill, and the gravels indicate sediment transported from below the bluff. The fourth layer was unconsolidated tan to light gray to grayish red mortar-rich clay loam and sand with numerous small angular rubble spalls representing debris from wall construction or chinking during the

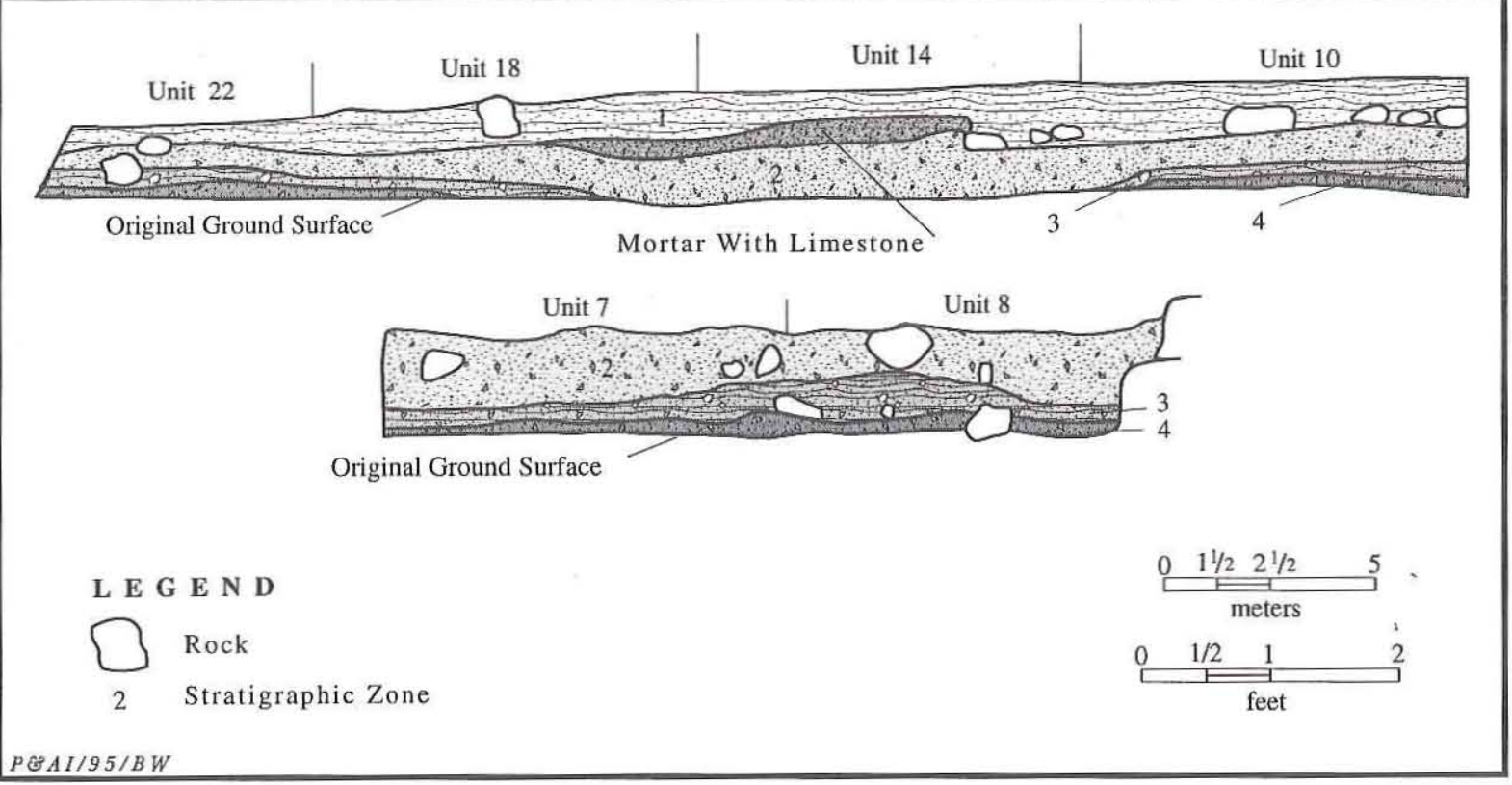

Figure 19. Profiles of Room 0 in Officers' Quarters 4. View to the west of the east walls of Units 10, 14, 18, and 22 (unexcavated) and view to the north of the south walls of Units 7 and 8 (unexcavated). 
pre-Civil War military occupation. This layer contained few artifacts. Neither the third nor fourth layers dating from construction occurred in the Unit 14 east profile in the center of the room, where the wall fall was directly above the dark gray to black sterile clay. Unit 14 did, however, contain a lens of mortar and moderate-sized rubble fragments from wall fall between the top and second layers; this lens continued into the Unit 18 east profile. The final layer was dark gray to black clay representing the original ground surface.

\section{ROOM 1}

The back room in this officers' quarters had a wood floor at one time as evidenced by the four (five, if the depression in the south ends of Units 18-20 also represents a joist) east-westoriented wood fragments and stains representing the remnants of floor joists spaced ca. 2-5 ft apart (Figure 20). An east-westoriented wood fragment at the south edge of the fireplace may represent another of these floor joists. Additional wood fragments oriented approximately east-west in Units 11 and 12 were found in upper deposits resulting from civilian-era wall repair. Only remnants of the east wall in the vicinity of Unit 12 were present during excavation, and this section of the wall appears to have been rebuilt several times. Irregular depressions in the original ground surface were present in the center of the room and along the west wall in the southwest corner. Rubble representing wall fall was present in the northeast corner. Exterior doors were present at the northwest and southeast corners of the room. A dozen nails were embedded in an arc in the northwest corner of the room. Ten of these were measured and ranged from 3 to $37 / 8$ inches long.

The fireplace vicinity was excavated in 1978, and Units 1-20 were excavated in 1984. The top layer in most of the units was a friable grayish

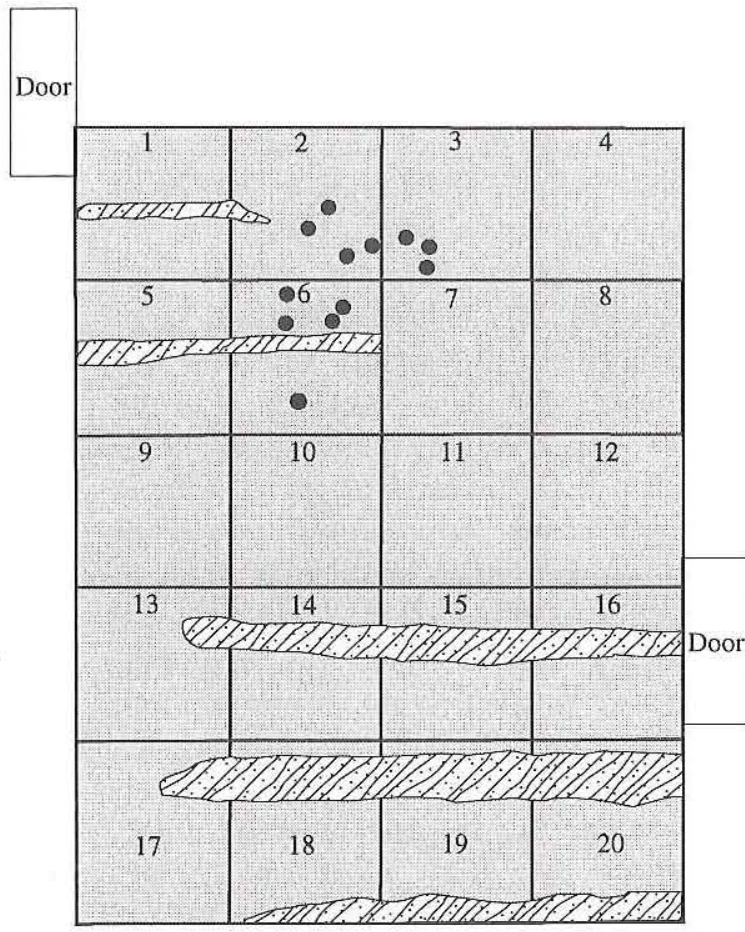
Excavation Joist Trench Nail
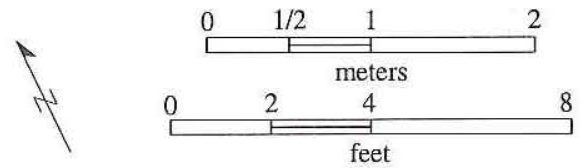
8

Plan of Room 1 of Officers' Quarters 4

brown to brownish gray sandy silt loam to clayey silt with few to moderate amounts of mortar and few to moderate limestone rubble fragments and pebbles (Figure 21). Most artifacts were contained within this layer. The origins of this layer were eolian, wall deterioration, and trash disposal. This layer was absent in the east balk profile of Unit 6 and the northern foot of Unit 10, which contained a high density of angular rubble fragments as well as stream cobbles and pebbles that appear to represent a mixture of two to three strata. In the north end of the room near the fireplace were two 1-2-ft rubble blocks that may have originated from the west wall or fireplace dismantling. The top layer was mixed with limestone gravels, pebbles, and cobbles in the east wall repair area in the southeast corner of the room, where the sandy silt loam underlay mortar from recent wall repair and a lens of wood (shingles?) fragments. Similar evidence of wall repair was found in the Units 15 and 16 south balk and Unit 18 east and west balk 


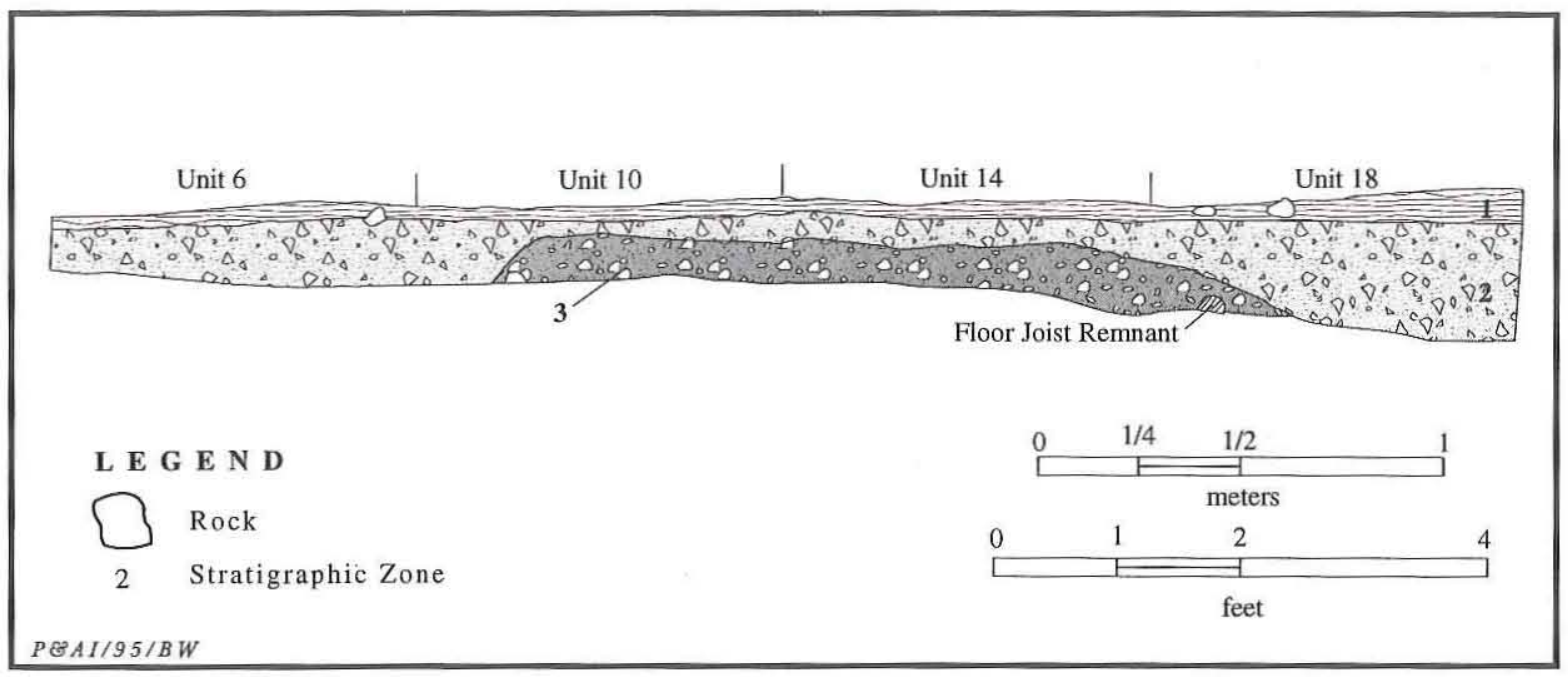

Figure 21. Profiles of Room 1 of Officers' Quarters 4. View to the east of the west walls of Units 6, 10, 14, and 18 (unexcavated).

profiles, where the top layer consisted of recent pink to reddish brown mortar, cement, and sand.

The second layer was a compact friable gray to grayish brown to reddish brown to pink sandy loam to clay with common to abundant pink mortar and limestone fragments resulting from wall deterioration. In the south balk profile of Unit 1, there was some mixing of this layer with the top clayey silt layer and stratification of the wall fall into two additional lower layers of gray clayey silt with moderate amounts of off-white mortar and rubble fragments and, below that, light pink pulverized mortar and rubble fragments. In the east balk profile of Unit 18 at the south end of the room, this layer was mottled pink, brown, and black mortar with angular rubble fragments. In Unit 16 adjacent to the east wall and in the east balk profiles of the south half of Unit 6 and the north half of Unit 10, this wall fall layer was mixed with the underlying clay containing imported stream-rolled gravels and pebbles.

The third layer was a compact friable pinkish gray clay with many stream-rolled gravels and pebbles. This zone occurred in the east balk profiles of Units 10,14 , and 18 . The gravel probably derived from below the site and may represent backfill or discarded walkway material. At the base of the zone in Unit 18 was a floor joist remnant.

Other strata occurred in the southeast corner of the room. The layer below the mixed second and third layers in Units 6 and 10 and above the sterile black clay consisted of clay with few to moderate pebbles. A lens of pink mortar occurred below this mixed layer. A lens of red clay containing mortar occurred beneath the wall fall layer and above sterile black clay with some limestone pebbles in the Unit 15 north balk profile.

\section{ROOM 2}

Excavation revealed an earlier wing with its front edge offset $3 \mathrm{ft}$ behind the front edge of Room 0 and contained within the area later enclosed to form Rooms 2 and 3 (Figure 22). The evidence of this wing consisted of a 1.5-2-ft-wide trench containing mortar and rock fragments. This first wing measured a maximum of $25 \mathrm{ft}$ east-west and $8 \mathrm{ft}+$ within the two rooms and extended into the adjacent kitchen yard. The first wing measured the same size as the later Room 3, $25 \times 14.5-15 \mathrm{ft}$.

The later wing was built flush with the front of the initial room (Room 0), and Room 3 was built before Room 2. Based on the abutment of the Room 2 walls onto the earlier walls of Rooms 0 and 3, the Room 2 area appears to have functioned as a breezeway before it was enclosed as a room. The symmetrical locations of the doorways to Rooms 0 and 3 at the south edge of the parallel walls also reflect the former breezeway function of this room.

Fifteen $3-\mathrm{x}-3-\mathrm{ft}$ units were excavated in this room. Units 13 and 15 were placed directly upon the wall foundations to expose them. Excavation 


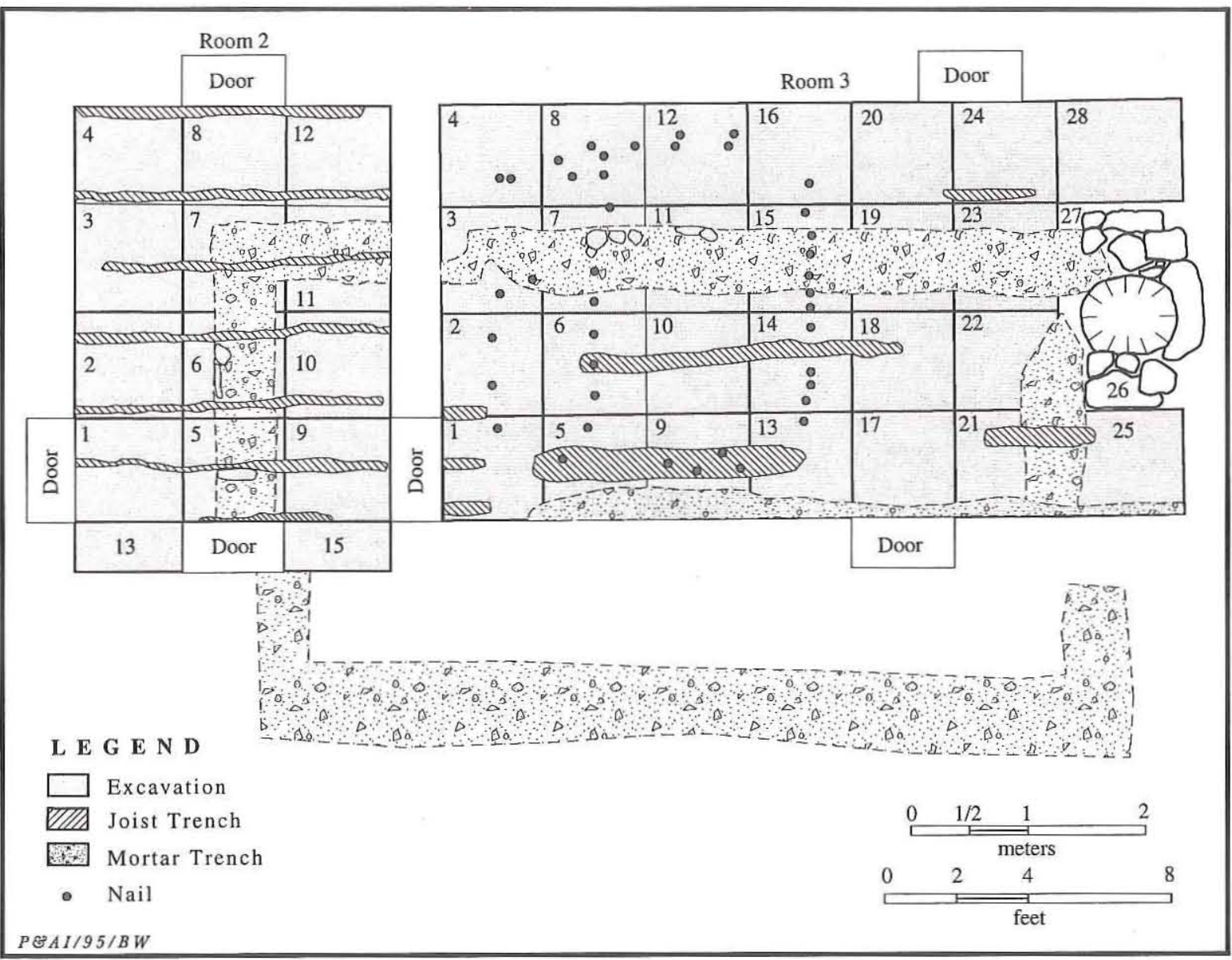

Figure 22. Plan of Rooms 2 and 3 of Officers' Quarters 4.

of Unit 13 on the southwest corner of the wall foundation showed the south wall to consist of a 1.5-2-ft-wide discontiguous foundation with some sediment accumulation where rocks had been removed. The south doorway and continuation of this wall in Unit 14 was marked by mortar pockets and a mortar bed on the very smooth sill stone and adjacent stones. Wood fragments represented remnants of the south joist, and nails with preserved wood resting on this sill were the remnants of flooring or of a baseboard oriented parallel to the joist. If this fragment represents a baseboard, then the doorway may have been filled in, which could account for the more discontiguous nature of its foundation and the location of the wood fragments. The north doorway, which is better preserved, is $3.5 \mathrm{ft}$ wide and consists of a sill stone with a mortar bed on its top face, additional foundation stones, and nailed doorsill and door frame remnants. A trench occurred along the east wall foundation in Unit 10 in the southeast corner of the room.

Seven east-west joists spaced at 1.5 -ft intervals occurred above the wall trench dating from the first wing. Some of the joists were set into trenches, or some leveling of the ground surface was done to set the joists. Concentrations of mortar also occurred between the two northernmost joist trenches and inside the south doorway. The northern concentration overlay the mortar and caliche stratum containing river gravels and angular rock fragments which, in turn, overlay the wall trench from the first wing. Thus, this concentration is associated with the construction or use of Room 2 rather than with the first wing. Similar concentrations occur adjacent to the joists in Unit 2 , neither of which is set into a trench. The southern mortar concentration probably is associated with the doorway. The northern joist in Unit 4 in the northwest corner of the room is set into 
what appears to be a very shallow trench. On the other hand, the southern joist in Unit 4 is set into a trench filled with mortar and limestone chunks.

A north-south profile along the east walls of Units 8, 6, and 14 and the west walls of Units 11 and 9 indicates the presence of at least five strata, with the top layer a loose to moderately compact light gray to light brown wind-blown silt to sand. The next layer in Unit 9 and in Units 8 and 6 was a moderately compact to compact tan to light grayish brown caliche and sand to caliche and silt with mortar and river gravels. The mortar in this layer probably represents wash from the walls following breach of roof integrity, and the sand may represent deteriorated mortar or, with the silt, wind-blown deposits. A compact red or reddish brown mortar and silt with river gravels occurred above the construction-era stratum in the north half of the room. A moderately compact to compact light brown to light grayish brown silt with river gravels occurred in Units 11 and 9. The sterile black clay basal deposit was overlain by a compact tan mortar and caliche stratum containing angular rocks and river gravels. The angular rocks and mortar are from wall fall. The river gravels must have been introduced since they naturally occur no closer than the base of the hill on which the fort is situated.

The north wall profile of Unit 6 indicated the presence of at least three strata above the sterile black clay. The top layer had dense mortar but moderate rock density probably representing wall wash. On at least two separate occasions, mortar that had washed from the walls alternated with eolian deposits. The layer of dense limestone fragments occurred above the black clay and the mortared wall trench in Unit 6. The wall trench containing mortar from the first wing was dug into the black clay in Unit 6 . A layer of dense mortar and limestone fragments representing room construction and wall fall lay directly on the black clay in Units 3 and 11. The joist in these units was set into a trench; in Unit 11 the joist was placed directly on the mortar and rocks remaining from the first wing wall trench, and in Unit 3 this trench was dug into the black clay and contained no earlier mortar.

The west wall profile of Unit 6 (Figure 23) contained three upper layers of pale brown to gray sandy silt to silty loam showing possible soil development (Strata 1-3). Below was a pale gray mortar lens (Stratum 4), and mortar also occurred in the top layer. Gray sand, limestone chips, mortar, river gravels, and sterile black clay were

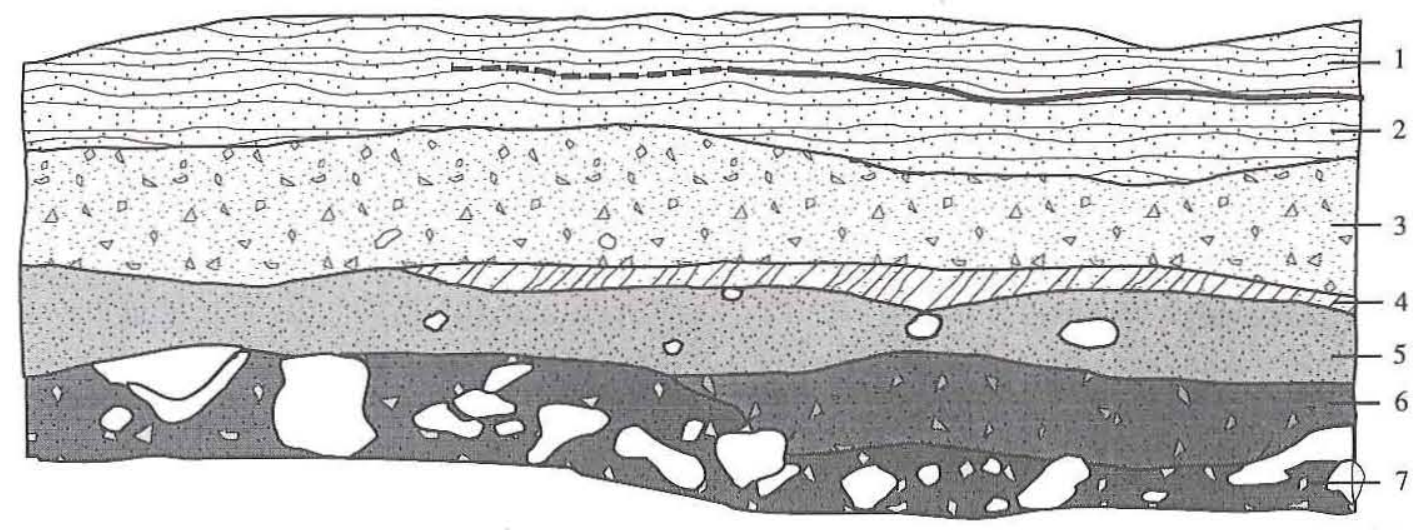

L E G E N D
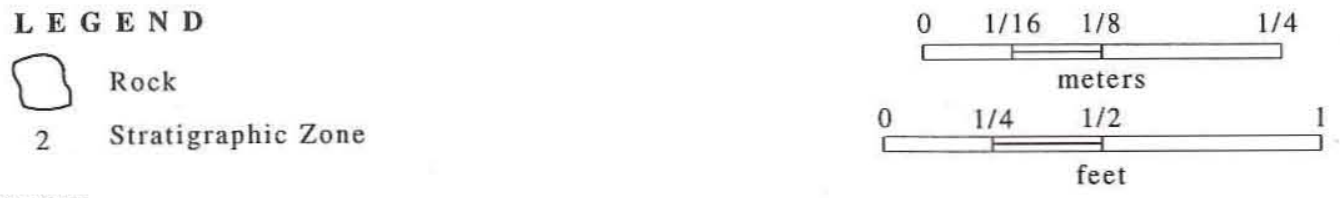

$P \& A 1 / 95 / B W$

Figure 23. West wall profile of Unit 6, Room 2, in Officers' Quarters 4. 
beneath in Strata 5 and 6, indicating wall fall possibly mixed with construction debris. The layer resting directly on the black clay (Stratum 7) contained large blocky limestone fragments that could be from dressing the stones, and the presence of a joist in this layer supports this interpretation.

The north wall profile of Unit 1 in the southwest corner of the room adjacent to the west doorway and the joist north of it indicated a mortar lens capping a layer of sediment with occasional rocks and charcoal apparently representing a buried A horizon. A dense layer of limestone and mortar lies above the joist and represents wall fall after the floor deteriorated or was removed. There is no evidence of construction debris in this portion of the room, but occasional mortar lenses are evidence of collapse of the adjacent west wall of the room. A lens of mortar caps the wall fall layer.

The north wall profile of Unit 9 in the southeast corner of the room adjacent to the east doorway and the joist north of it contained wind-blown sediments, wall fall, and grass roots in the top layer. The second and third layers consisted of wall fall and mortar, and the fourth layer consisted of mortar. The fifth through seventh layers contained river gravels not occurring naturally on the site; gravel density increased with greater depth. Mortar also occurred in the fifth layer. A wall fall layer of dense mortar and limestone chunks with little sediment was present in Unit 1 above the black clay.

\section{ROOM 3}

The interior dimensions of Room 3 are $21 \mathrm{ft}$ east-west by $12 \mathrm{ft}$ north-south. The three joist trenches are oriented east-west and are spaced at 3-4.5-ft intervals (see Figure 22). The room was excavated in twenty-eight $3-\mathrm{x}-3-\mathrm{ft}$ units.

Alignments of $4 \frac{3}{3} 4$-to-5-inch-long nails embedded in the layer below wall fall in the western half of the room appear to form a square pattern with the western one-third subdivided by an internal nail alignment. The nail pattern appears to be associated with the second Room 3 walls since it extends beyond the first wing wall trench. The nails do not appear to be associated with either wood or linoleum floors. The function of the nails remains unknown since they are too large to have been used to attach a covering to the packed dirt floor identified in Unit 25 that predated the wood floor associated with joist trenches.

In the southwest corner just inside the doorway were three joists oriented east-west, containing cut nails from the attached floorboards, and spaced $1.5 \mathrm{ft}$ apart. The joists appeared to consist of two boards, each 2 inches thick and approximately 3.5 inches wide. These joists extended across the doorway and spanned Room 2. The doorway joists were spaced at the $1.5-\mathrm{ft}$ intervals used in Room 2 and, since they extended into Room 3, confirm that the two rooms were floored at the same time.

The hearth in the east end of the room was $3.5 \mathrm{ft}$ deep and $5.7 \mathrm{ft}$ wide. Hearthstones in the center had been robbed, and a hole $2.5-3 \mathrm{ft}$ in diameter had been dug. Unit 26 on the south end of the hearth contained very ashy and loose sediment from the fireplace's use.

Unit 28 was adjacent to the fireplace in the northeast corner of the room. A pit containing rock and mortar in the west half of this unit cooccurred with an area of reddened silt, ash, and charcoal with a relatively high artifact density in the northeast corner. A board remnant oriented east-west (parallel with the joist trenches) occurred next to a hinge.

Unit 25 in the southeast corner of Room 3 contained four strata. The top layer consisted of a copious amount of recent pointing mortar dating from the stabilization of the room. Concrete from stabilization also was present in the northeast corner of the room. The first layer above the original floor in the southwest corner of the room consisted of loose, dry pinkish tan to tan sediment containing rocks, wood, mortar, and plaster from wall fall mixed with trash such as bones deposited in the abandoned and collapsing room. Two-inch holes in the sediments reflected rodent activity in the deposits. This wall fall layer in Units 9-12 was approximately 2-4 inches thick.

Below the wall fall or repointing stratum in the southeast corner was a layer from $0.1-0.2 \mathrm{ft}$ thick of deteriorated mortar and limestone rubble spalls apparently representing an older pointing episode or wall fall. This layer also contained broken glass, wire nails, and a wooden spatula.

A layer of brown fill which probably underlay a wood floor occurred in the southeast corner. The contact zone between the mortar layer and the brown fill below contained charcoal and wire nails, and the brown fill contained both cut and wire nails. The layer below joists and above sterile clay 
in the west end of the room consisted of brown sediments approximately 3-4 inches thick with mortar and plaster as well as mottled black clay, a hole-in-top can lid, and a crown cap.

The basal layer in the southeast corner was the black clay forming the original ground surface. Pink mortar was puddled in the southeast corner from original construction during one of the military occupations. The surface in the northwest corner of the unit had been packed from use as a dirt floor.

An area of red sediment in Units 8 and 12 had distinct boundaries. This sediment could be the remains of something burned. Reddish sediment also was present in Units 16 and 17, in Unit 15 above the wall trench containing mortar, in Unit 28 , and probably in additional units.

The top layer in Units 17 and 18 adjacent to the south doorway contained an ashy lens with a high density of modern artifacts. This layer appeared to contain trash thrown into the abandoned room through the doorway and represents the last use of the building for trash disposal.

\section{LATRINE OR SINK}

Excavation in a rock concentration in the interior southwest corner of the back wall $30 \mathrm{ft}$ south of Officers' Quarters 4 exposed large rocks and in situ mortar continuing under the back wall and representing the remains of the original wall and the adjacent latrine or sink. The latrine was cleared to obtain interior and exterior wall dimensions; to examine architectural details of doors, floors, and latrine trays; and to excavate interior sediments.

The latrine measured $5.5-6 \mathrm{ft}$ north-south by $9.5 \mathrm{ft}$ east-west. The north, east, and west walls were $1.5-2 \mathrm{ft}$ wide. The north, west, and east walls of the latrine consisted of opposed limestone blocks facing a rubble-and-mortar-filled core bonded with coarse lime sand mortar (Figure 24). Only the east wall retained courses above the foundation, with part of the first and second courses remaining. The doorway in the center of the north wall was marked by the absence of a mortar bed that in wall areas was the foundation for higher courses and by a horizontal board nailed to the foundation and forming the doorsill and aligned with the walkway leading to the back of the quarters (Room 1).
The east wall of the latrine abuts the back yard wall, which forms the south wall of the latrine. Disassembling of the 3.5-ft-wide compound wall and its associated rubble revealed the original mortared wall to be approximately $1.7 \mathrm{ft}$ wide. An additional 1.8-ft-wide dry-stacked stone wall was added over the remains of the latrine at a later date. These construction details indicate that the back yard wall was built first, the latrine second, and the addition to the back yard wall third. Remnants of the stone walkway are continuous with the north wall of the latrine and indicate contemporaneity of the latrine and walkway.

In removing the dry-stacked wall over the latrine, pecan hulls, apricot pits, many glass bottle fragments, snuff bottle fragments, newspaper, bones, wood, and leather were found. Little sediment was present between the rocks in the wall. Near the bottom of the wall were 7-Up bottle fragments, indicating that the wall probably was stacked during the twentieth century.

Wall fall inside the latrine was removed, and $0.5 \mathrm{ft}$ of sediments, including dark brown clay loam and tan brown clay loam mixed with plaster and mortar, were removed until the remains of the wood floor with in situ cut nail alignments were found. The interior was divided into three levels: (1) general interior fill; (2) fill from the latrine tray; and (3) matrix directly above the floor. These levels were excavated using trowels, brushes, and ice picks and were dry screened through $1 / 4$-inch mesh.

The latrine is a trough type containing remnants of a single tray removable for cleaning through the west wall. The tray remains consisted of bottom boards at least two boards wide and measuring $3.4 \mathrm{ft}$ east-west and $1.3 \mathrm{ft}$ north-south. The side board parallel to these is vertically oriented and $2.7 \mathrm{ft}$ long. The 0.8 - $\mathrm{ft}$-long end board abuts the side board and is nailed from the outer face of the side board. Four nails toed in southeast of the end board may represent the position of an upright in the center of the bench. No wood or nails were found in the southeast corner of the latrine and the east wall was higher than the west wall, indicating that this corner of the latrine had no tray.

The general interior fill contained a white porcelain doll foot; a beer bottle neck; brown, green, and purple bottle fragments; colorless window glass; three white ceramic shirt buttons; 


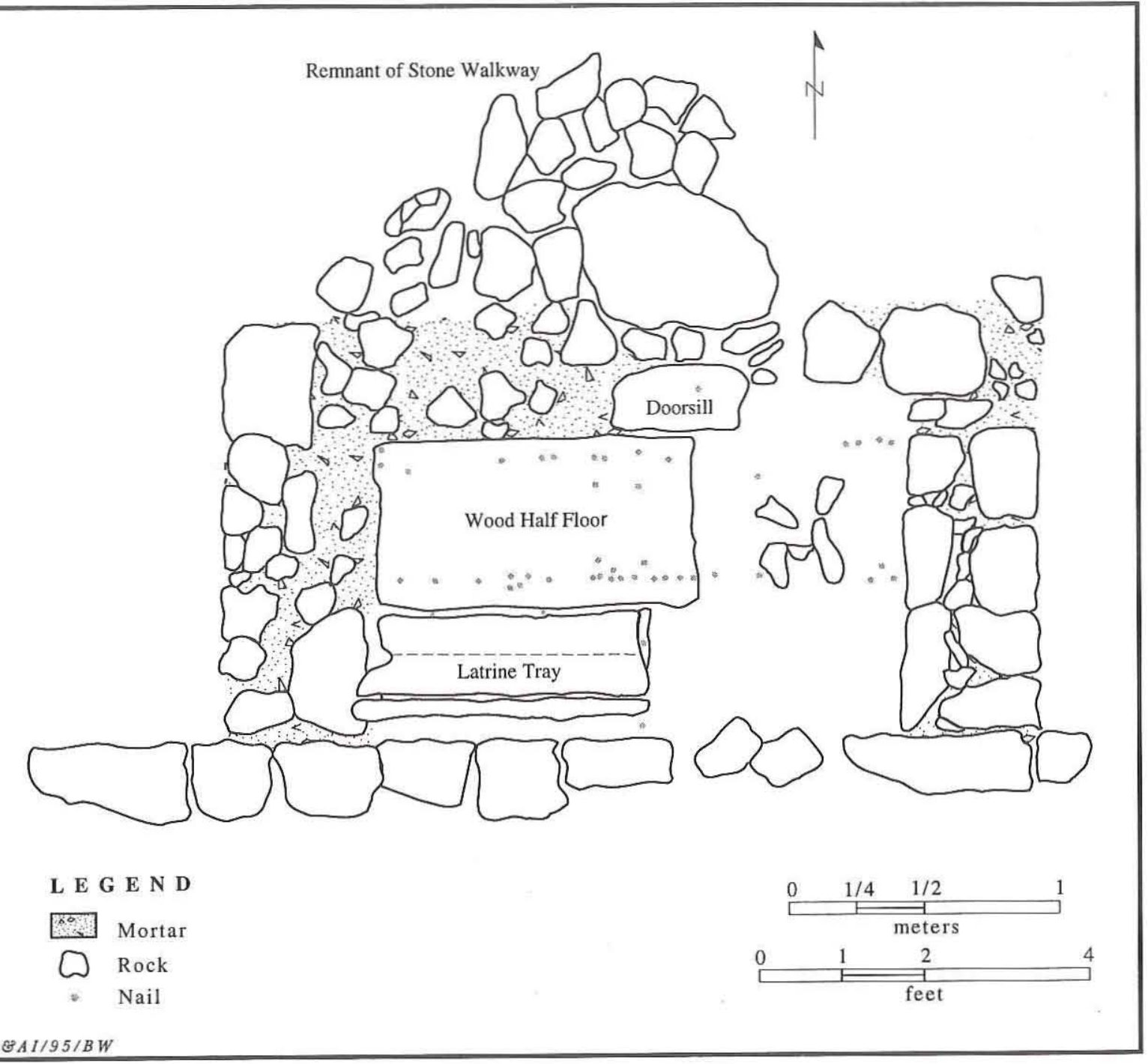

Figure 24. Plan of the Officers' Quarters 4 latrine.

cut nails; ferrous sheet metal; three cuprous military buttons; graphite and slate pencils; and bone fragments. The latrine tray fill contained brown and green bottle glass, cut nails, a cuprous straight pin, charcoal, and articulated chicken bones. The fill directly above the floorboards contained charcoal and ash as well as whiteware ceramics; colorless, green, and brown bottle fragments; colorless window glass; cut nails; a wood screw head; a cuprous artillery primer; and unidentified burned bones.

\section{EAST (KITCHEN) YARD}

A grid was established in the east and back yards of Officers' Quarters 4. The N0/E0 point was established at the southeast exterior corner of Room 1, and pins were placed every $4 \mathrm{ft}$ on the base line. Grid north is $20^{\circ}$ east of magnetic north. The east yard grid ranged from N0/E0 to $\mathrm{N} 30.5 / \mathrm{E} 32$ and was excavated in alternating checkerboard fashion except for contiguous units in the vicinity of the east door entryway or porch (see Figure 18).

A network of approximately $2 \mathrm{ft}$ wide walkways was found in the east and south yards. Most of these are flagstone edged with vertical slabs, although some disturbed areas lack stones. The east end of the kitchen yard is bordered by a north-south unlined 2-ft-wide walkway that may 
have linked the adjacent back yard walkways with the front porch of the quarters. This walkway defines the east end of the two-room wood-framed kitchen and ends $9 \mathrm{ft}$ south of the Room 3 south wall. The flagstone walkway remnant $6 \mathrm{ft}$ to the west of and nearly parallel with the eastern walkway defines the north edge of the kitchen and leads from the south door of Room 3 possibly to a north door of the kitchen. This walkway postdates the original Room 3 since it occurs inside the south wall of that room. Walkways also define the south edge of the kitchen. The southeast and southwest walkways with approximately right angle turns may have led to south doors in each room of the kitchen.

A covered entryway or porch marked by wall foundations extending $7 \mathrm{ft}$ east-west by $11 \mathrm{ft}$ north-south may have been present around the east door of Room 1. The wall configuration would have funneled traffic to the south from the exterior door to the latrine against the back yard wall. The entryway would have limited east-west access to the kitchen. The slight change in eave height in the roof above the door of Room 1 in the ca. 1912 photograph (see Figure 15) may be evidence of the former presence of a shed roof over this entryway. The foundations for the porch/entryway consist of a mortar-filled wall trench approximately $1-1.2 \mathrm{ft}$ wide. A mortar stain up to 12 inches wide along the west side of N16-20/E8-12 appeared to represent Room 1 wall fall rather than a mortar-filled wall trench, and wall fall was noted in the area of N8-12/E8-12 filling a hole. Because the east wall of Room 1 was repointed to the modern ground level but not to the original base of the wall, abundant mortar and cut nails to World War II-era artifacts were mixed with the sediments in the north half of the entryway. The entryway may date to the second military occupation or to the late-nineteenth-century occupation of the building.

An alignment of mortar stains representing the remains of the set-back original south, east, and west walls of Room 3 was found in the north part of the kitchen yard. The first wing mortar stains occurred in Units $4,10,13,15$, and 17, and the undisturbed wall remnants were $1.5-1.8 \mathrm{ft}$ wide. The deposits in Units 13 and 15 were considerably mottled sterile black clay with red clay or red clay loam containing construction debris or chinking stones in the form of limestone chips as well as angular cobbles representing wall remnants.
Perhaps related to the wood-framed kitchen are a limestone block and adjacent mortar bed in the south half of Unit 40 aligned approximately with three limestone slabs in the south half of Unit 38 to the west, forming a possible alignment $9 \mathrm{ft}$ long. The most definite portion of the alignment is in Unit 40 , and this could represent a corner aligned with both the north-south walkway to the south door of Room 3 and the east-west entryway wall north of the east door of Room 1. This alignment could represent a walkway predating or postdating the kitchen, pier stones for the kitchen foundation, or wall fall from entryway construction.

Five cartridge cases found in dark brown sediment just north of the kitchen were associated with the Unit 40 portion of the alignment. Additional artifacts from this vicinity, such as a cartridge case, a wire bottle closure, and an 1860 s shield nickel from Unit 49 and the cartridge cases from Unit 56, probably also are from a military deposit. These associations could support the preCivil War walkway or pier stone interpretations. North of the block and adjacent mortar bed, the sediment was mottled red, gray, and dark brown with pebble inclusions, indicating ground disturbance outside the possible feature area. An iron rod in this mottled area appears to be the frame and clasp for a fabric-covered bag or carrying case.

Although maps indicate this kitchen was present in 1875 , it is uncertain if it also existed during the first military occupation. Although a spaced-stone foundation would be expected for a wood-framed structure such as this, a mortared contiguous foundation such as that for the front building of the Old Hospital is possible. During the second military occupation, the kitchen probably was furnished with a stove or range.

Excavated units in the area of the kitchen structure (Units 47, 49, 54, 56, 58, 63, and 65) contained little mortar. Instead, the deposits were relatively more homogeneous than those in the northern part of the yard. Pebbles and cobbles were common at the base of the deposits, and these may represent spaced pier stones or scattered stones from the walkways and driveway to the south.

Ash lenses occur in the southwestern corners of the compact gray sandy clay in Units 54 and 63 in the southwestern portion of the kitchen. These lenses may represent remains of in situ burning of 
the wood structure, remains of burned secondary trash, or possibly discards from cleaning out the kitchen stove.

An east-west profile along the N8 line in the southern part of the yard through the former site of the wood kitchen documented two layers. At the surface was a loose grayish brown eolian sandy silt with very few limestone gravels. The second layer was more compact, more clayey, and grayer and had higher gravel and artifact content than the top layer. A pocket of gray mortar was present in the second layer in the Unit 56 north profile in the center of the kitchen.

An east-west profile along the N20 line in the yard north of the kitchen documented three layers. The top layer on the west side was a loose brown sandy silt containing humus, pebbles, and limestone cobbles, and on the east end was a loose brown silty sand root zone. In the Unit 22 south profile, oil stains occurred at the ground surface above a mortar bed in this layer, probably indicating a vehicle was parked or oil was spilled or disposed of in this area. The second layer was a compact gray to dark gray sandy clay loam or sandy clay or dark brown clay with mortar fragments, cobbles, and pebbles commonly present at its top and mortar concentrations, pebbles, and cobbles commonly present at its base. Charcoal fragments tended to occur in greater densities in the upper part of this layer than in the lower part. Red silty sand or clay occasionally occurred in this second layer. The basal layer was black clay loam.

A north-south profile along the E16 line through the western half of the kitchen and northern yard documented two strata above the basal clay. Adjacent to the Room 3 south wall for $4.5 \mathrm{ft}$, the top layer was predominantly deteriorated mortar mixed with limestone rocks and chips representing wall fall and construction debris plus the remains of the south wall of the original Room 3 ; the sparse sediment present was tan to pinkish tan to light brownish gray silty sand. There were puddles of recent gray mortar used in repointing the wall as well. Beyond the south wall of the first Room 3, the top layer was a loose brownish gray sandy silt to grayish brown silty sand to brown silty sand to brown silty loam root zone. A mortar lens at the base of the top layer in the south end of the Unit 63 west profile is probably from the adjacent walkway to the southwest.

The second layer in the E16 profile consisted of compact gray to dark gray to black sandy clay with small limestone rocks; this layer's color varied depending on the amount of charcoal content. In the southern half of the Unit 22 east profile and in the Unit 38 east profile, the sandy clay was mixed with red sand or silty sand and charcoal fragments. A lens of deteriorated mortar and small limestone chips occurred in the south half of the Unit 22 profile. Two areas of red clay mixed with the darker sediment occurred in the Unit 6 east profile. Charcoal was relatively abundant in the Unit 22 east profile and in the northern third of the Unit 15 west profile. Charcoal also occurred in the dark gray sandy clay in the Unit 31 west profile.

Lenses of angular limestone chips and mortar concentrations in dark brown clay in Unit 20 north of the kitchen could represent spalls from dressing construction stones or chinking stones deposited as wall fall. The central limestone chip concentration proved to be a rock-filled pit in the center of the unit. This 1.75 -ft-diameter pit was smaller than that adjacent to the Room 1 east entryway but may have served a similar function. Unit 20 is $4-8 \mathrm{ft}$ from four exterior walls - the original Room 3 south wall, the Room 2 south wall, the Room 0 east wall, and the Room 1 east entryway.

Small limestone gravels occurred throughout the sandy clay loam of Unit 29 north of the kitchen, and charcoal occurred in greater density in the northeast corner than in the remainder of the unit. A plan view at the base of excavations in black clay showed a concentration of limestone pebbles and crumbly mortar in the northwest corner and an area in the southeast corner containing larger angular limestone pebbles and cobbles probably representing wall fall, perhaps from the nearby Room 1 entryway.

\section{BACK YARD AND MISCELLANEOUS PROVENIENCES}

The walkway and driveway area in the back yard from N0/E0 at the southeast exterior corner of Room 1 east to N0/E60, southeast to S28/E34, and southwest to S20/W15 was cleared of vegetation and mapped. Excavation took place along the stone wall behind the quarters.

The walkways link the east door of Room 1 with the latrine built into the back wall behind the quarters, the presumed doors in the back wall of 
the kitchen with the driveway behind the quarters, and the quarters and kitchen with the double sink behind Officers' Quarters 5 to the east (see Figure 18). One of the walkways south of the kitchen leads east to Officers' Quarters 5, and two parallel walkways lead southeast to an opening behind the kitchen in the back wall (visible on the ca. 1871, 1875, and 1876 maps; see Figures 10, 12, and 13) into a former alley behind this row of officers' quarters (visible on the ca. 1875 bird's eye view [Sullivan 1981:2]). The parallel walkways are separated by a river gravel layer which represents an 8-ft-wide driveway leading to the kitchen.

The remnants of the western parallel walkway flagstones were laid evenly with shim stones and gravel beneath. The eastern parallel walkway lacks most of the edging stones, and the flagstones are not so evenly spaced as in the western walkway. The gravel at the head of the walkways at the southeast corner of Officers' Quarters 4 was less evenly distributed, less extensive, and more mixed with metal and nails than that in the driveway. Gravel also occurred at S15/E0 east of the walkway to the latrine. Ash and some charcoal overlaid gravel at the head of the walkways. Ash occurred in concentrations throughout N0-S10/E0-10 and at the southeast corner of the two mortar stains in N0-S5/E10-16. These two mortar stains apparently are the remnants of a walkway corner near where three walkways converge south of the east door of Room 1. Additional substantial mortar stains that represent walkway edges occur at S10/E0 and at S20/E30 (caliche is associated with the latter stain). Compact brownish gray silt is the dominant sediment at the head of the pathways in N0-S10/E0-10.

A 4-x-4-ft unit and a $2.5-\mathrm{x}-4-\mathrm{ft}$ unit were excavated adjacent to and east of the east latrine wall and against the back wall of the quarters yard. Whitewash stains $1.5 \mathrm{ft}$ wide were present on the inside of the extant (original) back yard fence and may represent remnants of the second wall built adjacent to the first and covering the latrine remains, although this latter wall was described as dry stacked rather than mortared.

A 1.7 - $\mathrm{ft}$ east-west by $1.3-\mathrm{ft}$ north-south unit was excavated in deposits sloping up against the south face of the back wall. This unit was $8.5 \mathrm{ft}$ from the east end of the quarters wall. These deposits consisted of (1) a top layer approximately $0.2 \mathrm{ft}$ thick of loose grayish brown sediments containing recent artifacts and wall fall, (2) an approximately $0.1 \mathrm{ft}$ thick layer of wall fall (rocks, mortar, and plaster), pebbles, and cut nails and ferrous metal, (3) an approximately $0.03 \mathrm{ft}$ thick layer of brown to black clay with no artifacts, and (4) a layer of in situ mortar adjacent to the base of the wall. Sterile black clay continues beyond the wall outside the mortar bed. The mortar bed is not continuous and extends no more than $0.2-0.3 \mathrm{ft}$ out from the wall. The second layer of wall fall consists of areas of compact pearl-white sediment with mortar chunks as well as a very friable yellowish white sediment with smaller mortar inclusions.

The existing front walk with an edged stone border and flagstone leads from the north-south road across the parade ground to the center of the Officers' Quarters 4 front porch. This walkway remnant (Figure 25) is $8 \mathrm{ft}$ from the porch and is $6.5 \mathrm{ft}$ wide and $10.5 \mathrm{ft}$ long.

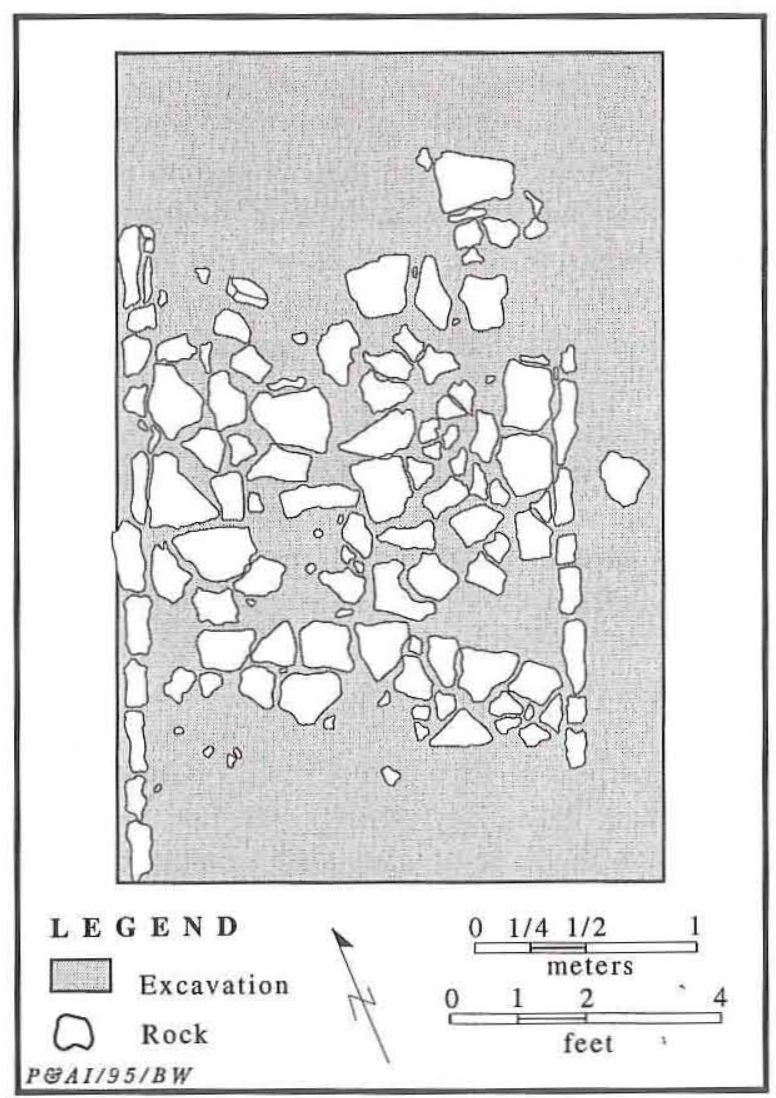

Figure 25. Plan of remnant front walkway of Officers' Quarters 4.

A trench north of the east wall of Room 3 encountered a cedar post from the front fence 
separating the quarters from the parade ground (shown in various twentieth-century photographs), and a fence rail from this fenceline was found $5 \mathrm{ft}$ east in the northeastern trench. A gravel-lined walkway was present in the trenches on both sides of the fenceline.

Alternating units along the west and north walls of Officers' Quarters 4 were excavated. The west wall units encountered an exterior wall trench extending 3-4 inches beyond the edge of the wall. Six 2-x-3-ft units were excavated west of the northwest exterior corner of Room 0 in a search for the original stone wall and its gate. A 6.5-ftlong mortar bed with rocks extended west from the northwest corner of Officers' Quarters 4 across the northern $2 \mathrm{ft}$ of Units 1,15 , and 16 , and the east half of Unit 17. This mortar bed also was identified in the northern $2 \mathrm{ft}$ of Unit 19 and the western half of Unit 18.

Seventeen units were excavated in the outline footprint of the foundation for the new front porch for this quarters. Thirteen 1-x-3-ft units (P1-9, $\mathrm{P} 11, \mathrm{P} 13, \mathrm{P} 14$, and P16) were excavated in a 48.5-ft-long east-west trench 77-89 inches from the front of the quarters. The remaining portions of the footprint were excavated in 1-ft-wide units on the west (WP1 and WP2) and east (EP1 and EP2). The 15-18-inch portions of these trenches adjacent to the front of the quarters had been excavated previously.

Profiles of the east and west trenches contained a layer of mortar from earlier porch supports. Mortar occurred in the WP1 and WP2 east profiles as a discrete bed in the second layer at $3-6.25 \mathrm{ft}$ from the front of the quarters. A layer of pebbles probably used in leveling porch joists and improving drainage underlies this mortar bed at 2.5-3 ft from the front of the building. The west profiles of EP2 and EP1 consisted of an upper layer of mortar or mixed mortar and sediment above a layer of dark clay with rocks, pebbles, and artifacts. Wire strands occurred in both mortar and dark clay layers.

The south profiles of the east-west trench units indicate an upper gray root zone with occasional to common pebbles and few to common rocks. The gray color probably is from mortar content in the sediment. The lowest layer is dark gray clay with pebbles and rocks. A lens of gray sediment occurs between the root zone and the clay in $\mathrm{P} 1$ and $\mathrm{P} 2$ in the western $3 \mathrm{ft}$ of the profile, and a lens of gravels occurs below this.

A possible posthole feature in P5 in the west center of the profile was encountered at $12-13 \mathrm{ft}$ from the west end of the trench. This posthole contained a cut nail at $0.8 \mathrm{ft}$ below the surface and rocks at its base and was approximately $0.5 \mathrm{ft}$ deep. The posthole contained the top gray root zone above a gray sediment with rocks, pebbles, and flecks above dark gray clay with pebbles. The dark gray clay in P4 adjacent to the posthole contained white flecks of calcium carbonate and rocks adjacent to a 0.15 -ft-thick layer of rocks.

Grayish brown sediments with pebbles and rocks occurred between the root zone and the clay in P7 and P8 in the center of the profile. A layer of rocks in the floor of the trench in P8 between 23.1 and $24.8 \mathrm{ft}$ from the west end of the trench represents a filled posthole or pit feature beneath the grayish brown sediments with pebbles and rocks.

In P13 and P14 in the western portion of the profile, the strata consisted of a top gray root zone above a dark gray clay with occasional rocks above dark gray clay with pebbles and rocks. A lens of gray sediment probably representing deteriorated mortar occurred at the surface in the center of P13. Four strands of baling wire near the base of the dark gray clay with occasional rocks at $0.35 \mathrm{ft}$ below the surface probably indicate post-military trash disposal.

A lens of gray sediments probably representing deteriorated mortar occurs below a thin gray root zone across P16 at the west end of the profile. Below this lens is dark clay with rocks and sheet iron.

\section{Officers' Quarters 4-5}

Two 2-x-4-ft units were placed midway between Officers' Quarters 4 and 5 to search for a wall dividing the side yards of the two quarters. No evidence of a wall was found, and this wall may never have been built. A pit for mixing lime mortar for wall construction was found. This pit was circular, $0.25 \mathrm{ft}$ deep, $2.4 \mathrm{ft}$ in diameter, lined with pink mortar, and filled with limestone rocks. Dog footprints in the mortar in the bottom of the pit reflect the presence of pets at the fort. Lime mortar lenses occurred directly above the rocks and at the surface in the east (?) end of the pit. This feature midway between the two buildings may 
have been used in the construction of one or both buildings.

A 4-x-4-ft unit was excavated just north of the $2-\mathrm{x}-4-\mathrm{ft}$ units to search for the dividing wall and to explore the extent of the mortar pit in the southern units. No remnants of a mortar trench or stones from a dividing wall were found. The brown loam to 7 inches below the surface contained very few rocks, all smaller than fist sized. At 7 inches below the surface, a concentration of flat-surfaced, rounded-edge rocks was exposed. These represented the edge of the mortar pit and indicated that this feature was circular with sloping walls.

\section{Officers' Quarters 5}

Officers' Quarters 5 is the second from the east end in the row of officers' quarters that bounds the south side of the main parade ground. The L-shaped structure has three rooms and was built of a combination of quarried and rubble limestone.

\section{History}

The northwest corner room of this structure originally was built as a one-room stone kitchen in 1853 and occupied as officers' quarters with the onset of winter. Rooms were added during the pre-Civil War and early post-Civil War occupations (Texas Parks and Wildlife Department 1975:235).

This quarters is not clearly identifiable in Sharpe and Horton's (1875) Surgeon General's report. The $53-\mathrm{x}-14-\mathrm{ft}$ building with a $23-\mathrm{x}-15-\mathrm{ft}$ ell in the rear and containing four rooms with large fireplaces for a captain and one lieutenant, with a tent used as a kitchen, could be Officers' Quarters 5 except that only three rooms were identified for this structure. The other possible description of this quarters is the $46-\mathrm{x}-16-\mathrm{ft}$ building with 27 -x-13-ft ell containing five rooms for one married and one single lieutenant, the problem being the discrepancy in number of rooms.

The 1874 map of Fort McKavett shows the quarters divided into three rooms with one set of steps on the west end of the porch (see Figure 11). The 1876 map shows the quarters divided into two wings, one consisting of the two rooms on the west side and the other consisting of the east room; two sets of front steps correspond with each wing of the quarters (see Figure 13). The 1874-1876 maps show the stone shed between the back wall of the quarters and the back wall of the yard (see Figures 11-13).

An 1890 photograph shows the relatively bare side yard of this structure (Figure 26). A 1912 photograph indicates that the shed was open to the front, had a shed roof sloping toward the back, and was connected to the residence by a covered walkway; the 1912 photograph also shows the windmill and tank in the side yard of this building (see Figure 15). A ca. 1936 photograph (Marvin Eickenrohlt Collection, Daughters of the Republic of Texas Library, San Antonio) also shows the covered walkway between the quarters and the shed as well as the wood rail fence between Officer's Quarters 5 and 6.

A 1936 HABS photograph taken from the northeast shows the picket fence along the front of this quarters, separating it from the main parade ground, the east end of the still-standing stone shed, and a twentieth-century wooden shed along the outside edge of the remnants of the back yard stone fence.

At the time of acquisition, the structure had been used as a storage building for many years. The addition of a corrugated steel roof in the early twentieth century had protected the structure so that a general lack of maintenance had not led to the destruction of the building. In recent years, however, one of the chimneys had collapsed below the roof line, and the metal roof was beginning to fail, allowing rain to enter the interior and accelerate deterioration of the ceilings, roof structure, and other interior features of the building. Fortunately, acquisition and stabilization occurred in time to prevent loss of the structure (Texas Parks and Wildlife Department 1975:236, 242).

Archeological work in the Officers' Quarters 5 vicinity took place in 1978,1979 , and the spring of 1985. Since no restoration was planned for the interior of this building, archeological work focused on the exterior and primarily on the collapsed masonry shed behind the quarters, with excavation in Rooms 1,3 , and 4 . In the vicinity of the officers' quarters itself, units were placed outside the south and east doorways of Room 2, the south doorway of Room 3, and the northeast corner of the building (Figure 27). 


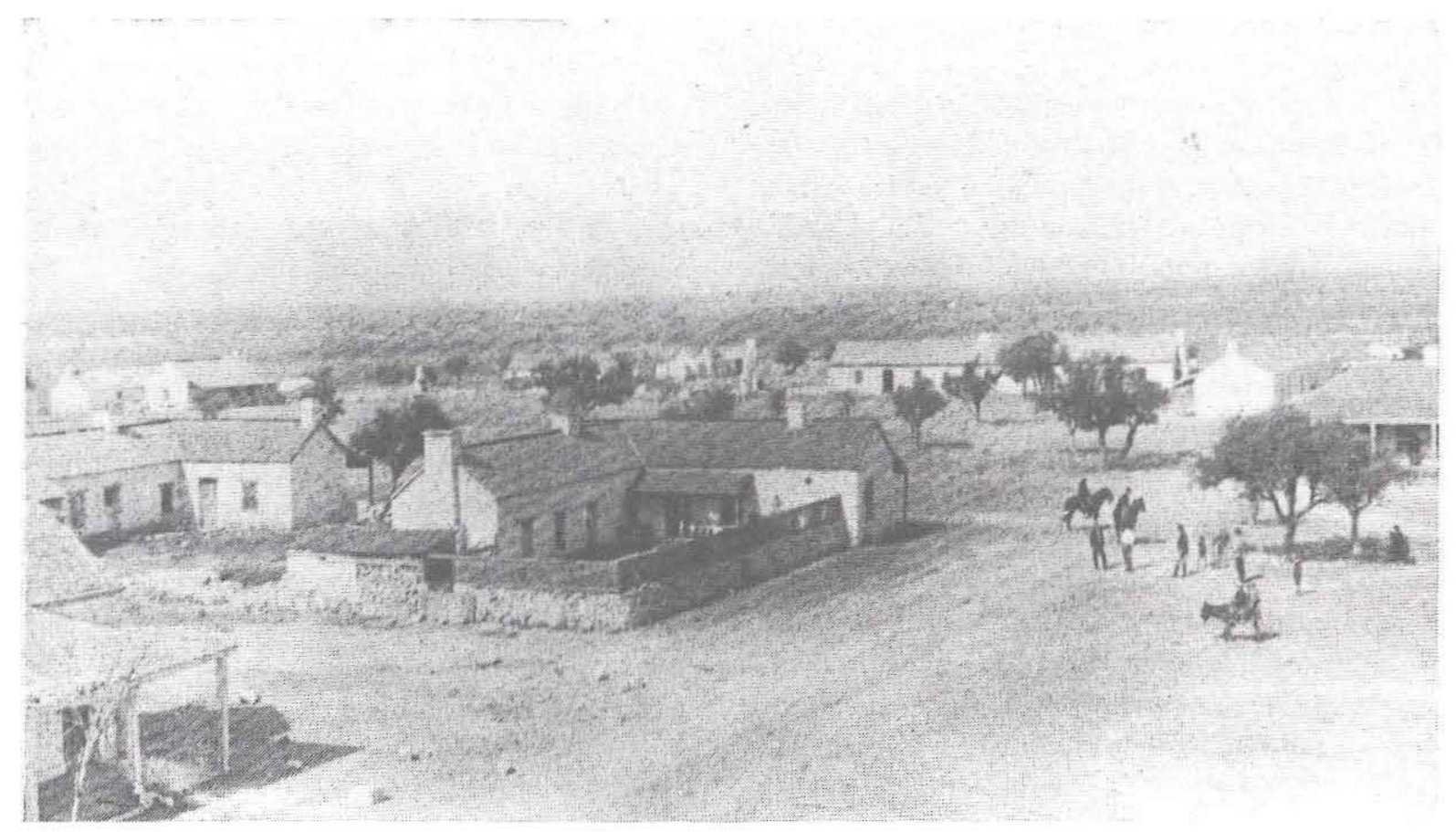

Figure 26. Photograph taken in 1890 of Officers' Quarters 11 (lower left corner), Officers' Quarters 5 (left), and Officers' Quarters 6 (center); view is to the north (Black and Ing 1980:79; Sullivan 1981:1; Texas Parks and Wildlife Department 1975:197).

\section{Archeological Results}

\section{ROOM 2 EXTERIOR}

The south exterior doorway had rubble supports on either side of the doorstep. The 2-x-5-ft unit in this area revealed a few rock remnants and the mortar bed remaining from a former doorstep; the mortar had extended up to $0.7 \mathrm{ft}$ south of the wall. Ash and silt overlay the mortar bed. The black clay subsoil beyond the mortar bed contained scattered rocks from construction debris or bedrock and was overlain by gravel in the southeast corner. The gravel could be from military or civilian occupation.

A 2-x-5-ft unit in the doorway in the east wall showed that the wooden sill and door frame were laid on a course of fist- to cobble-sized rubble extending under the walls and sill; only the undersill rocks adjacent to the walls were shaped to fit the angles and corners of the doorsill and wall junctures. The wall rocks were plastered to the undersill rocks. Many bones, including pig (pork chops) and cow bones, were recovered from this unit, and artifacts date to the nineteenth and twentieth centuries.

\section{ROOM 3 EXTERIOR}

A 3-x-5-ft unit was placed outside the exterior south doorway of Room 3. An 1890 photograph indicates this unit would have been on the west side of the south wall of Room 3 (see Figure 26). The flagstone doorsill rests on numerous rocks which combine with a rock underlying both the undersill and the east wall to form the foundation onto which the floorboards in the room interior were laid. The wooden doorsill is inset $0.6-0.7 \mathrm{ft}$ from the outer face of the south wall. The outer, rock portion of the doorsill is flagstone rubble.

The west half of the unit was excavated to the occupation surface above the bedrock and sterile soil, $0.5 \mathrm{ft}$ below the sill, and the east half of the unit was excavated down to solid bedrock, which contains rocks $0.5 \mathrm{ft}$ in size in front of the wall line and smaller rocks to the east. Undersill rocks were mortared directly to bedrock. The fill above the occupation surface contained many machine parts and pork chop bones, which in combination with a unit in the Room 2 east doorway may 


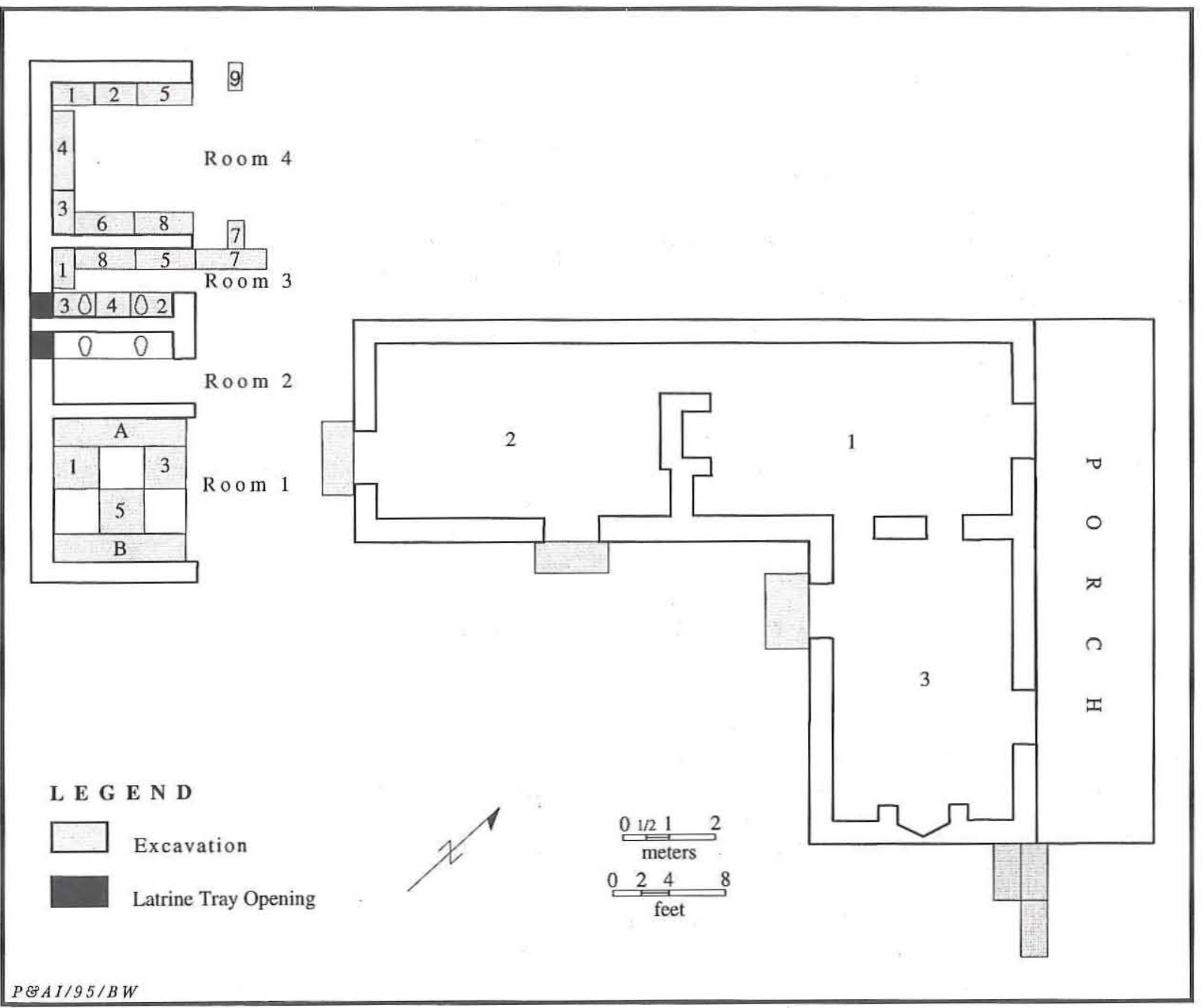

Figure 27. Plan of Officers' Quarters 5.

indicate civilian use of this building as a restaurant.

\section{NORTHEAST CORNER}

Three 2-x-4-ft units were placed adjacent to the northeast corner of the building in a search for the front fence extending west toward Officers' Quarters 4. The southwestern unit was excavated to $0.3 \mathrm{ft}$ below the surface. The west one-third of the unit was capped with mortar and stone debris from reconstruction of the quarters. Artifacts include ceramics, glass, wire nails, a buckle, a cartridge case, and animal bones. No large limestone fragments or traces of the back yard stone fence were found.

\section{SHED}

The shed originally contained a row of four rooms, labeled Rooms 1-4 from east to west, with a double sink or latrine occupying the central two rooms (Rooms 2 and 3). The rooms at each end of the shed (Rooms 1 and 4) apparently were used for storage. The shed consists of limestone rubble walls on the south, east, and west sides, with the rooms open to the north, facing the quarters (see Figure 27). Remnants of interior walls dividing rooms consisted of noncontiguous limestone rubble, and many of the rocks scattered in these room deposits appear to have resulted from wall fall. Based on a profile of Unit 3 in the southeast corner of Room 4, the foundation rocks were 
placed in a compact sediment with smaller gravel, and artifacts occurred to bedrock.

The shed contained many cedar posts, and mechanical excavation had pushed rocks and sediment into the shed area. The trash was removed from Room 1, and a sample of these predominantly twentieth century tin cans, bottles, cedar posts, and other materials (but including some military artifacts) was collected. Units were excavated along the interior walls of Rooms 1, 3, and 4. One additional unit was placed in front of Room 3, and two units were placed in front of Room 4. The gray ash overburden in Room 4 was not screened, but the brownish gray loam with gravel and charcoal was dry screened through $1 / 4^{-}$ inch mesh.

\section{Shed Room 1}

Room 1 measured $9.5 \mathrm{ft}$ north-south by $10.2 \mathrm{ft}$ east-west. Two-ft-wide units (Units B and A) $9 \mathrm{ft}$ long were placed along the east and west walls of this room. The southeast corner had at least $0.3-0.4 \mathrm{ft}$ of small gravel and charcoal overburden. The room was gridded into six approximately $3 \times 3 \mathrm{ft}$ units (Units 1-6), of which Units 1, 3, and 5 were excavated. At least two floors were present. A post-military-era floor with a shoe sole, horseshoe, wood chips, and glass fragment lying horizontal on a dirt floor in Unit 1 at 2 inches below the surface occurred above the floor level in Units A and B.

\section{Shed Room 3}

The sink at the 1874 hospital is of the same type as the double sink in the central two rooms of the Officers' Quarters 5 shed; the former's relatively intact condition is described to clarify this sink design. The sink was divided into two compartments with a door into each. A louvered window and exterior wood shutter were in each side wall of the hospital sink. The sink was an earth-closet type with removable trays beneath the wooden privy bench (Texas Parks and Wildlife Department 1975:202).

Double sink Rooms 2 and 3 have side-by-side tray openings to remove wastes from the back. The tray openings are each slightly less than $2 \mathrm{ft}$ wide. Based on tray size and room configuration, there were at least two seats in each of the latrine rooms (see Figure 27).

The area along the Room 3 interior walls was excavated in seven units (Units 1-7) ranging from $1.5 \times 2.5 \mathrm{ft}$ to $1.5 \times 5 \mathrm{ft}$. Mortar concentrations and a scatter of rocks at the base of the west wall in Units 1, 5, 6, and 7 represent construction debris. Floor joists leveled with rocks were present along the east and west walls, and one board remnant from the wood floor was found in the front of the room. Unit 3 in the southeast corner adjacent to the west latrine tray opening contained a north-south floor joist. A cornerstone set in a mortar bed was present at the northeast front edge of this room.

Unit 2 in the northeast corner was excavated to investigate a north-south floor joist found along the east wall of the room while cleaning out the shed. The floor joist was incompletely preserved and measured $2.8 \times 0.25 \mathrm{ft}$; it showed no evidence of joist sockets or supports. Beneath the south end of the joist was a concentration of rocks. The cornerstone at the northeast edge of this room was set in a mortar bed at $0.55 \mathrm{ft}$ below the surface and measured $2.6 \times 1.5 \mathrm{ft}$. An east-west-oriented wood floorboard fragment was parallel to the front sill of Rooms 2 and 3. The corresponding west end of this board was found near the surface in Unit 7, which also contained fist-sized to larger rocks and a concentration of ash and mortar in the north end. Stratigraphy consisted of unconsolidated brown sandy loam with gravel underlain by a darker brown clay loam, with ash and charcoal occurring in both layers.

\section{SHED ROOM 4}

The area along the storage Room 4 interior walls was excavated in eight units (Units 1-8). The west (outer) and south wall courses of this room are tied, not abutted, and the south wall has an offset foundation at its intersection with the west wall. The west wall courses above the foundation are flush with or slightly recessed from the foundation course.

Sediments were dry screened through $1 / 4$-inch mesh. On the surface in Unit 6 was a thin $(0.1-0.2 \mathrm{ft})$ layer of gray ash that was not screened, underlain by a 0.35 -ft-thick unconsolidated brownish gray loam with charcoal, mortar, and rocks of various sizes that represented wall fall. At the level of the base of the rock dividing 
wall was $0.4 \mathrm{ft}$ of brownish gray loam with less charcoal and more mortar flecks. No mortar or wood concentrations were noted, and artifact density was lower than in the layer above. Unit 1 in the southwest corner contained, beneath the trash and wall rubble at the surface, $0.3 \mathrm{ft}$ of dark grayish brown sediment with gravel and occasional egg-sized rock inclusions and, beginning at the top of the slightly larger foundation course, $0.3 \mathrm{ft}$ of the same sediment but with more gravel and plaster flecks probably predating the Civil War.

\section{Officers' Quarters 6}

Officers' Quarters 6 is in the southeast corner of the main parade ground, at the east end of the row of five officers' quarters (Officers' Quarters 2-6) along the south boundary of the parade ground and closest to the headquarters building and the row of captains' quarters (Officers' Quarters $7-10)$ to the east. This L-shaped structure has five rooms.

\section{History}

The corner room (Room 1) was built as a stone kitchen in 1853; this room and additions were occupied as officers' quarters during the preCivil War military occupation, and during the rebuilding program of $1868-1872$ the quarters were repaired and reoccupied (Texas Parks and Wildlife Department 1975:235). The structure was occupied by civilians during the late nineteenth and twentieth centuries.

A building described as $46 \mathrm{x} 16 \mathrm{ft}$ with a $27-\mathrm{x}-13$-ft ell and containing five rooms for one married and one single lieutenant (Sharpe and Horton 1875) possibly corresponds with Officers' Quarters 6. The other possibility is a $53-\mathrm{x}-14-\mathrm{ft}$ building with a rear $23-\mathrm{x}-15-\mathrm{ft}$ ell and containing four rooms with large fireplaces. The building housed a captain and a lieutenant, with a tent used for kitchen purposes. Although this quarters now has five rooms, east Room 5 is possibly an addition, and this is the only one of the five officers' quarters along the south side of the parade ground with four fireplaces. No divisions into rooms or wings are shown on the 1875 or 1876 maps of Fort McKavett (see Figures 12 and 13), but the 1874 map shows a division into four rooms (the back wing not divided) and two sets of entrance steps on the west half of the front porch (see Figure 11).

The sink is shown abutting the back wall of the yard on 1875 and 1876 maps. A cistern tank was placed in this vicinity during the civilian occupation.

An 1890 photograph shows a fireplace in the extreme south end of the quarters (see Figure 26), corresponding with the south end of Room 3, where no fireplace existed when the state acquired the property. Thus, after the chimney collapsed, civilian occupants apparently remodeled the south wall of this room.

The 1890 photograph shows the window in the south end of the east wall of Room 5; since this window was in the center of the wall when TPWD acquired the property, then this wall of Room 5 must have been remodeled. Similarly, the Room 5 south wall has no window in the historic photograph, but it did have one when the property was acquired.

The 1890 photograph clearly shows the back portion of this building. The two-room sink built into the front of the stone foundation back wall had a shed roof sloping down toward the back. The stone foundation wall is topped with a wood fence, possibly latticework, on the portion of the wall east of the shed and enclosing the east side of the yard from the adjacent street. The portion of the wall west of the shed consisted of rubble at this date.

An 1890 or ca. 1936 photograph (Sullivan 1981:55) shows a vertical-board room with a window on the west front of this quarters that represents an enclosure of the porch into a room.

By 1912, the fireplace on the south end of Room 3 had been removed and the window in the east wall of Room 5 had been moved to the center of the wall, but the window had not yet been cut in the south wall of Room 5 (see Figure 15). In the yard, the 1912 photograph shows the sink had been removed, the stone wall foundation had been removed and replaced by a wood fence set directly on the ground, and a board-and-batten outbuilding was in the southeast corner of the yard. Since this outbuilding has a false-front stepped facade and two windows, there is a gap in the fence to allow access, and it is located adjacent to the road, this outbuilding may have been used as a commercial building.

By ca. 1936, a view from the road (Marvin Eickenrohlt Collection, Daughters of the Republic 
of Texas Library, San Antonio) shows the wood picket fence and a rail fence separating this quarters' yard from that of Officers' Quarters 5. Since the view does not show the southeastern corner of the yard, the status of the commercial outbuilding at this date is unknown.

A view from the northeast of the front of this officers' quarters from the road along the east side of the main parade ground (HABS 1936) shows the picket fence along the front of the building. The front wall that extended west toward Officers' Quarters 5 is indicated on the ca. 1871 and 1875 maps (see Figures 10 and 12) and the ca. 1875 bird's-eye view of Fort McKavett from the east (Texas Parks and Wildlife Department 1975:162), and as a barbed-wire fence in the 1936 HABS photograph of Officers' Quarters 4-6 from the parade ground (Texas Parks and Wildlife Department 1975:239).

Officers' Quarters 6 was a standing structure maintained as a residence when TPWD acquired the property. The archeological work took place in the summer of 1978 , the spring of 1984 , and the spring of 1985. Excavation occurred in Rooms 1, 3, and 5 and outside the exterior doorways of

Rooms 1,4 , and 5 , in the vicinity of the former quarters wall on the west side of the building, in the front walkway to Room 4, and in the vicinity of the sink behind the quarters; in addition, work was done on the south exterior of Room 3 in the location of the former, probably military-era, fireplace (Figure 28).

\section{Archeological Results}

\section{ROOM 1}

Excavation in the vicinity of Room 1, the room built first as a kitchen and eventually becom-

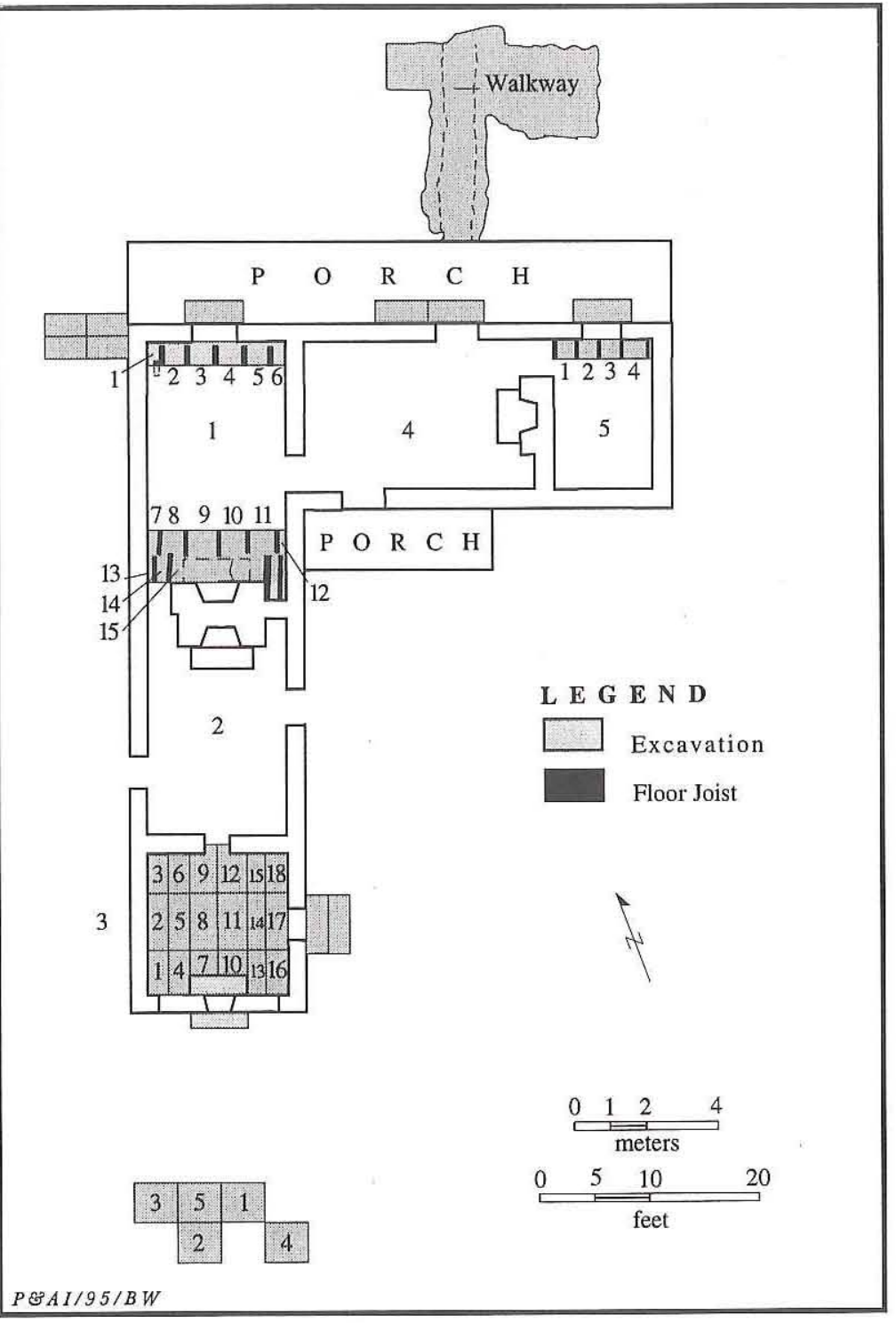

Figure 28. Plan of Officers' Quarters 6.

ing the corner room, included six units on the north interior inside the exterior door; nine units on the south end of the room to explore the double fireplace, interior door to Room 2, and cupboard door; and one unit outside the north door.

Civilian-era artifacts and linoleum were removed, the room was swept and photographed, and the upper wood floorboards were removed. This tongue-and-groove floor was pulled up board by board beginning on the east side of the room; boards were numbered from east to west, with letter designations from north to south, to facilitate replacement after restoration. The plank underfloor was swept and photographed. Before removal, the 
lower floor was numbered from north to south and letter designations were assigned from west to east. Excavation units beneath the wood floor were defined by joists.

Room 1 has three doors - one on the north, one on the east, and one on the southwest to the right of the fireplace. The height of the east and southwest doors is the same. The east side door apparently was the original exterior door. The room has two wood floors - the upper tongue-andgroove and the lower side-by-side plank. The lower floor planks are oriented east-west and are nailed to five joists spaced approximately $2 \mathrm{ft}$ apart. These joists are offset on the north end of the room. The upper floor is oriented perpendicular to the lower floor, with tongue-and-groove boards oriented north-south. A ledge is present on the interior of the wall because the walls are laid flush with the outside of the wide footing. Although these ledges at Fort McKavett often are used for seating the floor, this was not the case in Officers' Quarters 6. The room interior measures $11.6 \mathrm{ft}$ east-west from ledge to ledge.

The approximately $1-\mathrm{x}-8$-inch tongue-andgroove planks in the upper floor were laid in 17 rows of two planks each, with the longer plank placed alternately on the north and south ends. This floor was installed using cut nails on the tongue end of the boards. Planks were cut to fit along doorsill irregularities. The north wall doorsill, threshold, jambs, and wall boards extend to the upper floor, indicating that this door dates to the second, post-Civil War, occupation or was enlarged during that time. Two of the tongue-andgroove boards extend under the cupboard to the left (east) of the fireplace in the south end of the room, also indicating an association with the second military occupation.

The lower floor consists of side-by-side rough-milled 1-inch pine or cypress planks of varying widths. The east doorsill rests on this underfloor, indicating contemporaneity with this floor. Wear patterns on this floor occur around the hearth on the south and the door on the north wall but are not deep, indicating that the floor probably was covered relatively quickly. Unworn areas in the northeast and northwest corners of the room may represent bed or table areas. Adze marks on one board may indicate thinning to level the upper floor.

Four strata were recognized in the south end of the room in the vicinity of the double fireplace. Unconsolidated material that sifted between the floorboards formed the top depositional layer. During the post-Civil War rebuilding period, wood floors were laid and pinkish orange sediment was introduced to level the floor joists. A few fragments of the bacon-box floor were recovered. The 1850 s construction surface was used as a dirt floor until approximately $1855-1857$, when bacon-box flooring was placed directly on the dirt floor.

Building debris was removed from the Room 1 (north) side of the double fireplace in a search for a hearthstone or underfire. Beneath the building debris was a patchy ash lens, fine rock chips and lime dust, and black clay sediments. Most of the fireplace materials appeared to have been removed, but a very small portion of the underfire was intact. Above this was an ash deposit. The original hearthstone was approximately $2 \times 5.5 \mathrm{ft}$ and was set on a stone and mortar bedding (Figure 29 ); the bedding probably raised the stone to a level slightly above the level of the wood floors, indicating a probable association with the later military occupation (Figure 30 ). The bedding was set on the dirt floor dating to construction in 1853 , and the ash beneath the stone may reflect initial use of the hearth without a hearthstone. This hearthstone was removed and a smaller, fractured one set in its place and leveled with a layer of loose chinking stones and no mortar, although there is mortar between the hearthstone and the underfire. An olive green wine bottle was found in unconsolidated fill beneath the hearthstone, and an 1868 coin and a military button were found west of the hearth.

Definite evidence of pre- and post-Civil War military occupations was found in Room 1. Unit sizes in Room 1 were defined by the floor joists. Four approximately 2-x-2-ft units (Units 2-5) and two approximately 1-x-2-ft units (Units 1 and 6) were excavated on the north end of the room. The joists rested on introduced fill with their tops above the wall ledge.

The top layer consisted of unconsolidated fill between the joists. Much of this material had been disturbed by rodents, but the fill in the extreme north end of Units 5 and 6 near the wall was relatively undisturbed. In Unit 4 the unconsolidated tan fill contained rocks, plaster, glass, nails, adzed wood, and pecan and acorn hulls. The second layer in Units 5 and 6 was brown sediment 


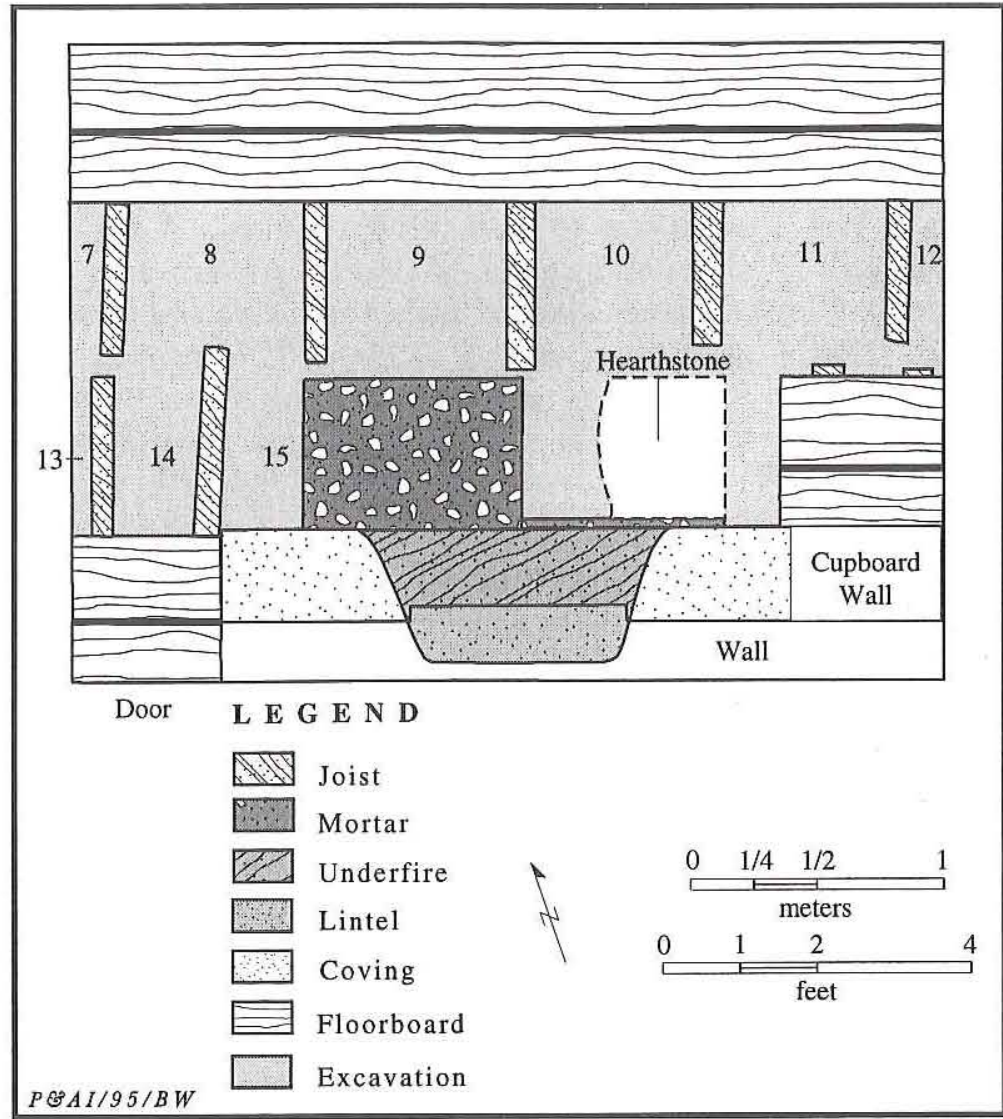

Figure 29. Plan of the south end of Room 1 in Officers' Quarters 6. artifacts in this layer are an 1867 coin, an 1868 trade token, military buttons, shoulder scaleboards, and olive green beer and wine bottle fragments.

There were two compact occupation surfaces near the fireplace. The upper layer was even with the joists and was used to level them. This was a 0.2-0.3-ft-thick layer of fairly compact pinkish orange sand with small gravels. A military button was found in this layer. Underlying the introduced fill was a fairly compact dirt floor approximately $0.1 \mathrm{ft}$ thick and containing abundant ash. This layer represents the 1850 s dirt floor. Beneath the ash was a section of white plaster that probably represents the remnants of a spill from wall plastering. Pink mortar was puddled on top of the plaster in several places.

Small nails with fragments of canvas (?) attached in the unconsolidated fill in Units 9-11 may be from the original canvas ceilintroduced to level the joists. The third layer in the north end of Room 1 was compact black clay sediments which may represent an 1850 s occupation floor. At the top of compact clay in Unit 6 was a concentration of lime mortar flecks which were embedded in this dirt floor.

Units $7-15$ on the south end of the room were excavated within a $4.3-\mathrm{x}-11.6-\mathrm{ft}$ area beneath the floorboards in front of the double fireplace. The units were of widely variable sizes because the floor joists were discontinuous, with the Room 1 floor joists ending at the front of the fireplace, and joists supporting the doorway and cupboard extending along either side of the fireplace leading into Room 2. Units 9, 10, 11, and 14 were excavated to the lowest dirt floor.

The unconsolidated powdery silt material represented nineteenth- and twentieth-century sweepings that had filtered through cracks between the floorboards, and fine screening recovered straight pins, seed beads, and lead shot. Some of the diagnostic nineteenth-century and military ing. Canvas embedded in plaster also occurred in the fill of Unit 11. Fill above the dirt floor in Units 10 and 11 was a light tan color containing many rounded river gravels. The dirt floor was dark gray and similar to the black layer on the north end. Units $7,8,12,13$, and 15 were excavated to the top of the introduced fill.

\section{ROOM 1 EXTERIOR}

A $2-\mathrm{x}-5-\mathrm{ft}$ unit was excavated outside the north exterior door of Room 1 . The upper 2 inches contained a ceramic button, a cut nail, and recent chicken bones in unconsolidated sediments with gravel. At 3 inches below the surface, the sediments were compact coarse clay loam with gravel. Scattered stones in this layer ranged from large pebble sized to 5 -x-4-inch chunks.

\section{ROOM 3}

The Room 3 interior was excavated com- 


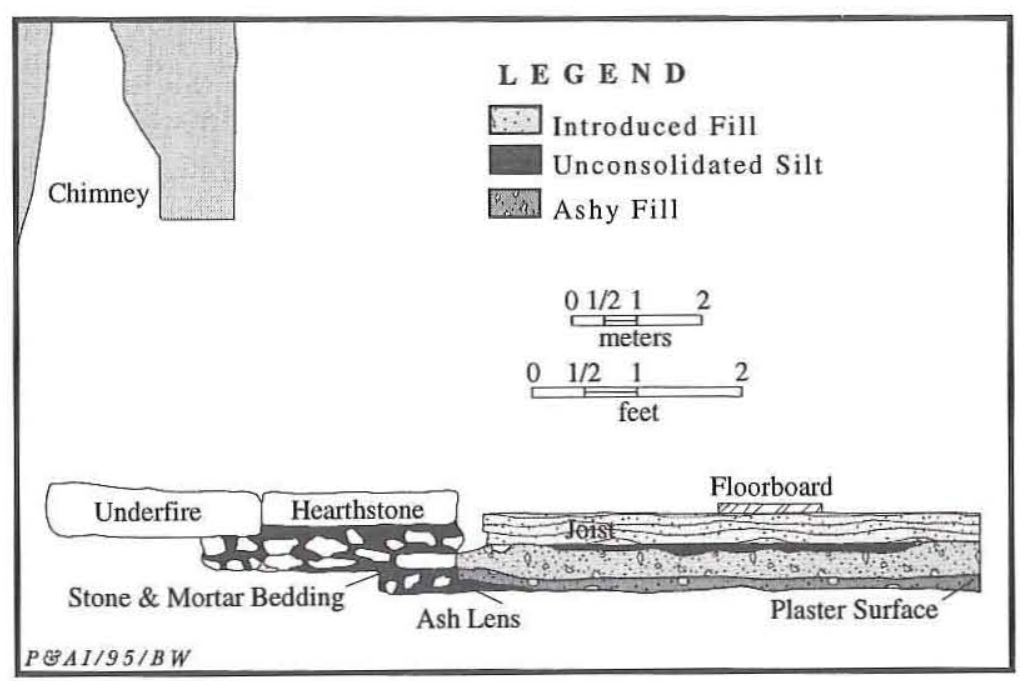

Figure 30. West-facing profile in the vicinity of the fireplace in Room 1 in Officers' Quarters 6.

pletely by 18 units of varying dimensions defined by floor joists and 1 unit in the interior fireplace; additional excavation in the vicinity of this room consisted of 2 units outside the exterior door on the east and an exterior unit in the former fireplace in the south wall. Units were excavated to expose floor joists and to determine what surface they were placed upon, to examine subfloor deposits, and to recover fort-period artifacts to date the associated architecture.

Before excavations began, the two sets of floorboards were removed. The lower floor was mapped and photographed. The floor joists defined three rows of six units each, and an additional unit was placed in the fireplace in the south wall. Unconsolidated sediments were brushed with whisk brooms and fine screened through $1 / 16$-inch mesh, and compacted sediments were excavated with trowels and screened through $1 / 4-$ and occasionally $1 / 8$ - or $1 / 16$-inch mesh.

Room 3 measures approximately $11.8 \mathrm{ft}$ eastwest by $12 \mathrm{ft}$ north-south. The room had two wood floors. The top floor was laid north-south, and the lower floor was laid east-west.

The north-south joists were $0.3-0.35 \mathrm{ft}$ wide and were spaced at approximately 2 -ft intervals. The north ends of the central Room 3 joists overlap in extent with the south ends of the two Room 2 doorway joists, suggesting that Rooms 2 and 3 were floored at the same time. The joists in Units 9 and 12 on the north end of the room were set in unconsolidated fill which may represent joist trenches. Linear depressions noted in Units 3 and 6 east of the two westernmost joists also may represent the remnants of footing trenches or preparation and leveling of the original ground surface. Units 2 and 5 also have 2-inchwide and 2-3-inch-deep depressions near the joists on the east and west sides of the units. Rock underlies the joists in Unit 9 in the north center of the room. Three $0.3-\mathrm{x}-0.3-\mathrm{ft}$ floor joists were uncovered in Units 14 and 17 , the easternmost of which extends under the baseboard of the east wall, indicating that the floor predates the baseboard placement. Unit 16 in the southeast corner of the room adjoins the rock wall on the south and a baseboard on the east wall. Rocks occurred along the rock wall and joists, and gray ash occurred next to the west joist.

A 1.8-x-5-ft unit in the interior of the south wall explored the former fireplace location based on an 1890 s photograph. The lime mortar used in rebuilding this south wall appears identical to that used in military construction. Other indications of the former fireplace included two of the northsouth joists in the south end of the room not extending to the wall or baseboard, similar to joist configuration in the vicinity of the Room 1 fireplace. Several tabular rocks and traces of an eastwest joist ca. $0.5 \mathrm{ft}$ from the south wall of the room were found in the compact layer. The rocks may have been the base or shims for a hearthstone. Above the dark brown compact surface and in the center of the unit was dark brownish gray sediment that may have been fireplace residue. The presence of a small amount of ashy and burned material next to the wall may have resulted from filtering through the crack between the hearthstone and the underfire if the fireplace coving was nearly flush with the inside wall. Artifacts include a cup with pink luster decoration and a military, button.

A unit measuring $1.8 \mathrm{ft}$ north-south by $5 \mathrm{ft}$ east-west in the middle of the exterior south wall was placed to examine the former fireplace area. The top layer was unconsolidated fine brown topsoil introduced for landscaping purposes and containing brown bottle glass, window glass, cut 
and wire nails, and metal hardware within 1-1.5 inches of the surface. Under the topsoil is a crumbly mud mortar layer, possibly containing ash, that was more compact than the topsoil. At 5.75 inches below the surface, a still more compact surface contained lime mortar and plaster chips along with five deeply embedded scattered stones. The stones were remnants of a fireplace foundation in the south wall of this room, and the plaster chips were from the wall into which the fireplace was set. The mud mortar above, then, would be from the wall that was remodeled without a fireplace. Temporally diagnostic artifacts from this fireplace area include an olive green wine bottle base.

The $0.1-0.5$-ft-thick layer directly beneath the Room 3 floorboards consisted of unconsolidated light brown to light gray to grayish brown to very light grayish brown fine to very fine sediments containing mortar, some small angular and rounded rocks, and cultural materials ranging from military buttons to recent twentieth-century artifacts. This layer, which represents floor siftings and occurred in all units, contained the greatest density of artifacts. In Units $2,5,8$, and 11 in the west center of the room, a compact 1-inch variant of this layer was present.

The 0.1-0.5-ft-thick second layer consisted of compact to very compact grayish brown to pinkish brown to orange to mottled pink/tan/black clay loam containing mortar (some of it puddled from spilling during application), lime, angular limestone chips, rounded limestone rocks, ash, and a few artifacts. This layer occurred in all but Units 1,2 , and 4 in the southwest corner of the room. The floor joists were set into this layer of construction debris or into the sterile layer below.

The third layer, 2-3 inches thick, consisted of dark brown to very dark brown to dark grayish brown compact clay loam with crumbly texture and containing many large pebble- to fist-sized rocks and bedrock. This layer, which represents the original ground surface before military occupation, was exposed in all but Units 6,14, and 17, and some of the floor joists were set into this layer.

Unit 8 in the west center of the room had deposits identical with those in Unit 5 except that the compact dark basal layer was not caked and crumbly as in other units but had finer texture and was more easily workable. The basal layer in Unit 11 had texture most similar to the north end of
Unit 8 in its even consistency and larger grain.

Artifacts decreased in frequency with increasing depth. The artifacts indicate that this room was used as a kitchen.

\section{ROOM 3 EXTERIOR}

A 2-x-5-ft unit was placed outside the east door of Room 3. The top layer of flower bed fill was removed and not screened, but most of the remaining deposits were screened. A concentration of rocks was present directly in front of the doorsill at 0.1 to $0.3 \mathrm{ft}$ below the surface. Small gravel pockets were scattered in the fill and above the rocks. Root disturbance was so extensive that no living surface could be identified with certainty. A second 2-x-5-ft unit was placed just to the east to determine the size and function of the rock concentration. Materials in this unit were not screened because of the low artifact yield in the other unit. The rocks were interpreted as possibly a natural outcrop that was used as a cobbled walkway connecting the doors of Rooms 2,3 , and 4 on this back side of the building.

\section{ROOM 4 EXTERIOR}

A 2-x-5-ft unit was excavated in the porch area outside the north exterior door of Room 4 . The top 3 inches of unconsolidated sediment contained bottles, cut and recent wire nails, buttons, and marbles. Wood and plaster from construction occurred in a compact living surface just above the sterile clay and bedrock. These materials apparently were deposited during floor sweeping into a hole in the steps.

An adjacent 2-x-5-ft unit was excavated to the west of the Room 4 north door. Artifacts occurred primarily in the upper unconsolidated sediment and near the living surface in contact with the north wall. Artifacts along the wall include glass, a clay marble, and a poker chip that apparently fell between the porch and north wall. Except for nails, there was less evidence of construction debris than in front of the door.

The artifact distributions and relative paucity of construction debris indicate a porch was present shortly after construction of this part of the building. The living surface is not extensively compacted, also supporting porch construction relatively soon after building construction. 


\section{ROOM 5}

Four units were excavated in the north end of Room 5 inside the exterior door, which had been a window during the military occupation. Two layers of patched and pieced linoleum and baseboards were removed. The tongue-and-groove wood floor was photographed and mapped, and then the floorboards were labeled, measured, and removed. The flooring was tightly fitted and had warped; it was drier and in worse condition than the Room 1 floor. Floorboards were laid with the tongue on the north side and the groove on the south side. Plank widths were more varied than lengths. Floorboards were pieced to fit the uneven rock and plastered wall bases. Baseboards were attached with cut and wire nails and were filled with cement. Some floorboards had random green and red painted and varnished areas on their undersides that were installed before the paint or varnish was dry; these may represent tests of the paint and varnish. Four floorboards were removed from the north end of the room, and four floorboards were removed from the center of the room to facilitate subfloor excavation.

The door of Room 5 was narrower and the lintels and jambs wider than in other rooms because of its original function as a window. The wood-framed south wall overlay the flooring and was separating from the adjacent masonry wall at the corner. Stones from the south wall were used to support the frame wall and to form a window ledge. The ceiling contained 6-inch boards painted grayish brown. The flooring consisted of 4-5-inch planks laid east-west.

In the north end of the room, Units 1-4 were separated by five 2-x-8-inch floor joists spaced about $2 \mathrm{ft}$ apart and placed north-south directly on sediments. Deposits consisting of floor sweepings and rodent nest accumulations in Units 1 and 2 were banked up against the north wall and contained primarily early-twentieth-century artifacts with the exception of an 1879 silver dollar from Unit 2. The dirt floor contained some puddled mortar and small limestone chinking rocks from building construction. The joists and wood floor probably were built soon after wall construction judging by the lack of military-period artifacts in the deposits below the floorboards. The second layer was primarily construction debris with sparse artifacts. The construction debris consisted of lime mortar spills and chunks, small limestone chinking, and some mud mortar. There was mud mortar at the base of the wall, indicating that it was set in mud mortar on the ground surface or in a shallow trench. The third layer was sterile dark brown clay and bedrock. The paucity of military-period deposits may indicate construction of this room late in the second military occupation.

In Unit 3 adjacent to the north door, a top layer of unconsolidated sediments contained floor siftings and rodent nest accumulation such as match sticks, fabric, paper, buttons, clay marbles, and cardboard box fragments. The underlying original dirt floor surface was noticeably more compact and contained badly rotted boards, puddled plaster, mud mortar, and rocks representing construction debris. The plaster-covered stone walls extend below the depth of the joists.

Unit 4 in the northeast corner contained bottles; small personal items such as hairpins, buttons, and round and square matches; cut and wire nails; screws; and newspaper fragments. Wood fragments from flooring overlay construction debris.

Deposits in the center of the room were primarily compact sediments with some construction debris. The sparsity of artifacts did not indicate use of the floor as a living surface.

\section{ROOM 5 EXTERIOR}

A 2-x-5-ft unit was placed outside the north door of Room 5. This area is the lowest point in the ground surface along the front of the quarters and collects water. The top layer was sticky black clay $0.1-0.2 \mathrm{ft}$ thick. The next layer contained mud mortar splashes, lime mortar, tan mud mortar, and nails and was approximately $0.1-0.2 \mathrm{ft}$ thick. This disturbed layer contained construction debris and later artifacts. The final layer was sterile black clay with limestone bedrock. Few artifacts were found.

\section{EXTERIOR SINK OR LATRINE}

Five 4-x-4-ft units were placed $16 \mathrm{ft}$ south of the south edge of Room 3 to search for remains of the sink recorded in this area in archival records. An 8- $\mathrm{ft}$ north-south by $16-\mathrm{ft}$ east-west grid was established along the wall behind Officers' Quarters 6. Materials were dry screened through 1/4-inch mesh. 
The first layer was $0.1 \mathrm{ft}$ of very unconsolidated and dry sediment, which was brushed and surface collected. Units 1-3 showed evidence of burning along the central axis of the grid. Unit 1 contained a north-south-oriented trench $0.1 \mathrm{ft}$ deep. Small rock debris and pink mortar on bedrock were remnants of sink or later structure construction. Unit 2 contained charcoal and ash, particularly in the east half of the unit, below unconsolidated surface materials. Unit 3 contained ashy sediment, and the east half of the unit contained a small shallow pit with small rocks in the bottom. Units 4 and 5 contained construction sand approximately $0.1 \mathrm{ft}$ thick, gray burned material, and bedrock. The sink area deposits appear to be shallow and disturbed, reflecting the destruction of the sink and construction of a cistern tank during the civilian occupation.

\section{EXTERIOR WALKWAY}

The gravel-lined walkway $7-25 \mathrm{ft}$ from the front of the building and accessing the porch facing Room 4 was excavated in an irregularly shaped unit. The north-south-oriented gravel and flagstone walkway was $3 \mathrm{ft}$ wide and led to the Room 4 front door. The small pea-sized gravels in the walkway occurred above cobbles and surrounding unshaped tabular limestone. No border was present to contain the gravel within the walkway. Wire and cut nails are mixed in the upper gravel layer, suggesting post-military deposition. At the porch dripline, 4-x-6-x-4-inch stones overlay and were mixed with the gravel, suggesting that the gravel was used to level the larger stones. Near the porch, the upper layer overlying the flagstone contained ash and most of the artifacts; the ash deposit extended approximately 6 inches on either side of the walkway. Just outside the porch area, the stones extend to the west and could represent an east-west walkway. In some places mortar was still in place; its date is uncertain. Some of the gravel in the area north of Room 5 and $0.1-0.2 \mathrm{ft}$ below the present ground surface was angular and may correlate with the angular gravel bedding in the walkway in front of the Room 4 front door.

\section{EXTERIOR UNITS AT THE NORTHWEST CORNER OF THE BUILDING}

Four adjacent 2-x-4-ft units were placed at the northwest edge of the building in the hope of locating the front fence that extended west toward Officers' Quarters 5. The front fence is shown with an entrance west of the excavated area on the ca. 1871 and 1875 maps (see Figures 10 and 12) and the ca. 1875 bird's-eye view of the fort from the east (Texas Parks and Wildlife Department 1975:162), and as a barbed-wire fence in the 1936 HABS photograph of Officers' Quarters 4-6 from the parade ground (Texas Parks and Wildlife Department 1975:239).

The top layer at $0-0.3 \mathrm{ft}$ in the northeastern unit consisted of mottled brown sandy loam introduced for a wheelchair ramp and containing twentieth-century glass and wire nails. Cobble-, boulder-, and pebble-sized pieces of limestone encountered at $0.5 \mathrm{ft}$ represent bedrock. Artifacts include glass, nails, and a white ceramic button. The southeastern unit was excavated to $0.225 \mathrm{ft}$ below the surface. Sediments were clay loam. Artifacts include whiteware and stoneware ceramics, bottle and window glass, nails, a clay marble, and animal bones. The northwestern unit contained an upper layer of light brown sandy loam introduced for a wheelchair ramp; this layer was not screened. The second layer was a very dark brown clay loam excavated to $0.5 \mathrm{ft}$, at which point limestone pebbles $<0.1$ to $0.6 \mathrm{ft}$ representing bedrock were encountered. Artifacts are bottle and window glass, nails, wire, and animal bones. The upper brown-tan layer in the southwestern unit generally was discarded because it represented introduced fill. The second layer of black clay in bedrock contained artifacts. No mortar was observed, and no stain or trench remaining from the fence was found. No evidence of the front fence was found in these units.

\section{Officers' Quarters 7}

This officers' quarters is on the north end of the row of four captains' quarters on the east side of the parade ground between the commanding officer's quarters and the headquarters. Officers' Quarters 7 was an L-shaped structure with three or four rooms. The orientation of the ell is reversed from that of Officers' Quarters 8-10.

\section{History}

The row of captains' quarters was constructed 
during the 1868-1872 post-Civil War rebuilding period (Texas Parks and Wildlife Department 1975:235). The Surgeon General's report (Sharpe and Horton 1875) indicated that one of these quarters had a 15-x-12-ft kitchen. The 1874 map of Fort McKavett shows the structure as consisting of three stone rooms and a back frame room with a sink against the back wall of the quarters (see Figure 11). The 1875 map shows the floor plans as consisting of two or three stone rooms with a frame addition on the back (see Figure 12). The 1876 map shows a division between the back room and the front rooms; Officer's Quarters 7 is represented as having two rooms, rather than one, on the back and as extending to the back fence and sink (see Figure 13). The back room shown on this map could represent the kitchen described a year earlier.

This quarters was a ruin with only low limestone walls remaining when archeological work took place in two rooms in 1979. Additional surface collection by park personnel took place during the spring of 1984. Archeological excavation took place only in the southwest corner of the structure, although the fireplace of the northwest room was examined as well. The goal of the archeological work was to examine sediments and architectural details, to obtain associated artifacts, and to determine if burned wood in the southwest corner was associated with an original floor surface.

\section{Archeological Results}

Vegetation was cleared from the foundation walls using rakes, hoes, snips, and brooms, and building corners were exposed. Excavation was by trowel, ice pick, and whisk broom, and sediment was dry screened through $1 / 4$-inch mesh.

A single 3-x-3-ft unit was placed in the southwest corner of the structure. Two wood fragments burned on their top surfaces and well preserved underneath appear to be the remnants of two wood floors with floorboards laid perpendicular to each other. A north-south floorboard fragment overlies an east-west-oriented lower floorboard fragment, and the east-west fragment appears to be set directly on the south wall rubble foundation. A rock that overlay this fragment may be in situ or could represent wall fall. There was no evidence of floor joists or joist sockets (?). Cut nails were found in the area of the wood fragments and probably indicate the floor (or floors) dates to the military occupation.

The top layer of sediment consisted of pinkish brown sandy silty loam containing roots and extending from the surface to $0.6 \mathrm{ft}$ below surface. The pinkish color was derived from decomposed mortar. The wood fragments were found in this top layer. The second layer graded from pinkish brown to pinkish gray to gray and contained charcoal, melted glass, and mortar chunks. At $1 \mathrm{ft}$ below the surface, the original ground surface of dark gray to black clay was encountered. Since both the wood fragments in the top layer and artifacts and inclusions in the lower layer show evidence of burning, it appears that there were two separate fire episodes in this room.

The fireplace on the east wall of the northwest room was examined. A ferrous metal spherical solid shot (?) fragment was found on the surface of the hearth. Also present were a William Henry Harrison token (see Coins and Tokens, Chapter 5) and wood fragments.

\section{Officers' Quarters 8}

Officers' Quarters 8 is the second from the north in the row of four captains' quarters built on the east side of the parade ground between the headquarters and commanding officer's quarters. This officers' quarters is an L-shaped structure with four rooms.

\section{History}

This structure was built during the 1868-1872 post-Civil War rebuilding period. The front rooms are shown as stone, and the back room (Room 3) is represented on the 1874 and 1875 maps as wood and on the 1876 map as stone (see Figures 11-13). A 1936 HABS photograph taken from the southwest and another photograph from approximately the same location and date show the wood rail fence and gate separating this structure from Farm to Market Road 864.

When the structure was obtained by TPWD in about 1975, it was being maintained as a private residence. A tin roof had been installed, the wood porch columns had been replaced, and windows and doors had been modernized (Texas Parks and Wildlife Department 1975:242). 
Archeological work took place in the fall of 1978 and focused on the exterior edges of the walls forming the north side of the main wing and the east side of the ell (Room 1) on the northeast side of the building (Figure 31). One unit was excavated on the south exterior door/window of Room 2, and one unit was excavated along the south end of the front porch. Work along walls on the north side was aimed at exposing possible walkways to indicate military-era foot traffic flow patterns and at recovering associated artifacts, and work in the vicinity of the doorsteps was aimed at determining their age and association with pre- or post-Civil War or civilian occupations.

\section{Archeological Results}

\section{ROOM 1 EAST EXTERIOR WALL AND ROOMS 2 AND 3 EXTERIOR NORTH WALLS AND DOORWAYS}

Work on the north side of the building consisted of clearing vegetation to approximately $1.5 \mathrm{ft}$ from the building walls and excavation in the vicinity of two doorsteps. Sediments were not screened.

The only flagstone paving was found on the east side of the Room 2 doorway close to the surface. Adjacent to and west of the Room 3 exterior doorsteps was a concentration of rock rubble resting on bedrock and overlain by orangecolored deteriorated mortar. The rubble may represent debris from a rebuilding episode. In the area between these doorways was 1-4 inches of clay topsoil containing scattered rocks approximately 3 inches above bedrock and not forming a flagstone surface. Also present were burned wood and ash near the rock rubble pile and artifacts including ceramics, brown bottle glass, chimney lamp glass, cut and wire nails, and a ferrous metal button.

Very little sediment $(0.1-0.4 \mathrm{ft})$ was present above bedrock in the exterior wall area. The area between the east exterior doorway of Room 1 and the northeast corner of this room had less than 1 inch of sediment above bedrock except for the base of the tree in the northeast corner, where there was some 2 inches of soil development. The only artifacts were cut and wire nail fragments, a plastic tubular bead, and a bone fragment. The exterior walls of Rooms 0 and 1 where they join at the ell

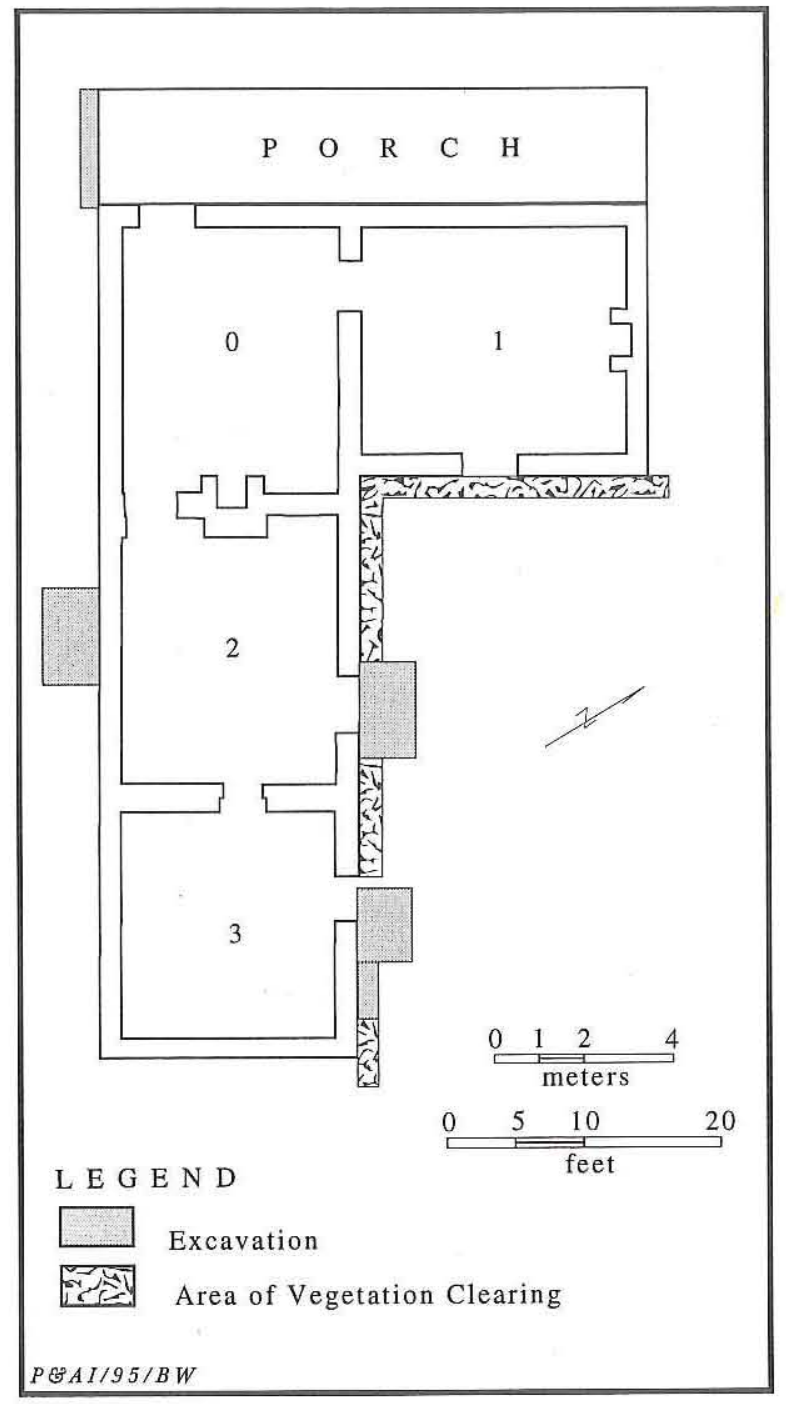

Figure 31. Plan of Officers' Quarters 8.

appear to have been built directly on bedrock.

A 1.5- $\mathrm{ft}$ trench excavated from the east edge of the Room 3 exterior doorway to within $3 \mathrm{ft}$ of the northeast corner of Room 3 encountered very dark and clayey sediments approximately $0.8 \mathrm{ft}$ deep with charcoal at the base of this layer. Ceramic and glass artifacts and plastic toy and flower artifacts are twentieth century in age. Two rocks had been removed from the wall, forming a hole $0.9 \mathrm{ft}$ east of the doorway and $1 \mathrm{ft}$ above bedrock.

At the east edge of the north wall of Room 3, a 0.1-ft-thick lens of brownish red deteriorated mortar occurred $0.2 \mathrm{ft}$ below the surface and $0.6 \mathrm{ft}$ above bedrock. Artifacts appear to be turn of the century or later and were associated with the civilian occupation. 
Two areas were excavated adjacent to doorsteps on the north side of the building. One was outside the north exterior door of Room 2, and the other was outside the north exterior door of Room 3. The sediment in the former was a dark grayish brown clay loam with a $0.6-\mathrm{x}-0.5$-ft concentration of decomposed very pale brown sandy mortar. Aluminum pull tabs and other twentieth-century artifacts were recovered.

The sediment in the latter was a dark grayish brown clay loam, a brownish yellow sandy loam, and a very dark grayish brown clay loam (Figure 32). A brass buckle and a concentration of large-caliber rimfire cartridge cases were found along the east side of the Room 3 steps in the very dark grayish brown clay loam. The unit in front of these steps contained a layer of abundant deteriorated tan sandy mortar above the layer of clay loam, which contained gray ash, small pieces of scattered charcoal, and 0.2-0.3-ft limestone pieces. Artifacts consisting of twentieth-century battery cores, plastic toys, and canning jars occurred in greater densities than in the unit by the Room 2 door. The Room 3 steps appear to be more recent than the Room 2 steps because of the diversity of sediment accumulation beneath the steps, which contrasts with the more common pattern at Fort McKavett of military-period construction directly on bedrock and/or dark brown clay loam.

\section{ROOM 2 EXTERIOR SOUTH DOOR/WINDOW}

The exterior doorsteps on the south side of Room 2 lie below the remnants of a doorway that has been altered into a window. The steps were constructed of limestone blocks with cement and sand mortar. A 4-x-6.5-ft unit was placed adjacent to these steps to determine their age. The surface sediment was a brownish tan sandy loam $0.1-0.15 \mathrm{ft}$ thick. Beneath this was caliche roadbed aggregate $0.3-0.4 \mathrm{ft}$ thick, underlain by black clay loam and bedrock. The caliche aggregate indicates twentieth-century construction. Earlytwentieth-century artifacts, including automobile parts, wire nails, and venetian blind parts, were present above and below the caliche layer.

\section{FRONT PORCH, SOUTH END}

A 1.5-x-8-ft unit was placed adjacent to the south end of the Officers' Quarters 8 front porch. The top 4-6 inches consisted of caliche roadbed aggregate above 1-3 inches of dark sediment. Solid bedrock lies 3-4 inches below the bottom of the caliche layer. Adjacent to the porch, concrete spread on the edge of the porch was less than 1 inch from bedrock material. Artifacts including a shoulder scaleboard, glass sherds, cut and wire nails, and a spark plug portion were sparse and reflect both military and civilian occupations.

\section{Officers' Quarters 9}

Officers' Quarters 9 is the third from the north in the row of four captains' quarters built on the east side of the secondary parade ground between the commanding officer's quarters and the headquarters. This officers' quarters is an Lshaped structure containing four rooms. 


\section{History}

This quarters was built during the 1868-1872 post-Civil War rebuilding period. The front rooms are shown as stone, and an additional back room (Room 4) is shown as wood on the 1874 and 1875 maps and as stone on the 1876 map (see Figures 11-13). The shed-roofed addition on the back that was present in 1975 when the property was acquired (Texas Parks and Wildlife Department 1975:242) was present in 1936 as shown in a HABS photograph from the southwest. This 1936 photograph also shows that the front yard fence separating the structure from Farm to Market Road 864 was wood picket on the south side and barbed wire on the north end. When acquired, the structure was being maintained as a private residence.

Archeological work took place in the fall of 1978. Excavations took place in the easternmost room (Room 4) interior and in exterior areas north of the porch, north of Room 3, north of Room 4, and along the walkway south of the building (Figure 33).

\section{Archeological Results}

\section{ROOM 4}

A 3-x-3-ft unit in the southeast corner of Room 4 was placed to search for evidence of a living surface and to recover artifacts that may have been deposited beneath the wood floor. All sediments were fine screened. The top $0.1-0.15 \mathrm{ft}$ was very unconsolidated brown sand and contained sparse artifacts including cut nails, window glass, and bones. The second layer consisted of very dark brown clay containing many angular limestone chips, chinking-sized stones, and bedrock outcrops of large, rounded limestone. The only artifact is a brown glass fragment. The angular and chinking stones are debris from dress- ing stones and constructing the building walls during the post-Civil War military occupation. Troweling along the east wall indicated that the wall footing was placed directly on bedrock.

A 3-x-3-ft unit was placed in the northwest corner of the room to examine the stratigraphy and construction of the north exterior door area. Several large rocks and recent artifacts were removed from the surface, and then excavated sediments were dry screened through $1 / 4-$ and $1 / 16$-inch mesh. Five strata were recognized. The top layer was unconsolidated brown sediment from 
0-0.2 ft deep (bedrock was exposed in portions of the unit). This layer contained angular and rounded rocks, most of the artifacts, and some roots. The second layer, which occurred in the northeast corner of the unit and was $0.05-0.2 \mathrm{ft}$ thick, was a reddish clay loam with small rounded rocks and a few decomposed metal fragments. Below this was a $0.15-0.2$-ft-layer of burned limestone with few artifacts (another lens of burned limestone occurred beneath the undersill rocks). The fourth layer consisted of friable dark grayish brown clay loam $0.1-0.2 \mathrm{ft}$ thick. Wood fragments possibly from the original floor were present in the northwest corner. This layer probably represents the original ground surface and dates to the post-Civil War military occupation. Bedrock forms the final stratum. Artifacts occurred primarily in the surface layer, and artifact density decreases with depth.

A 3-x-3-ft unit was placed in the center of the east wall of Room 4 to search for a possible former stove location and for charcoal or ash and associated military artifacts. Sediments were screened through $1 / 4$ - and $1 / 16$-inch mesh. The top level of loose dark grayish brown sediment was $0.1-0.25 \mathrm{ft}$ thick and contained twentieth-century and possibly earlier artifacts including a brass object and cast iron stove part, small angular rocks, several large rocks, and roots. The stove part and charcoal occurred in a concentration in the southeast corner of the unit underneath a $2.5-\mathrm{x}-0.6-\mathrm{ft}$ rock lying parallel to the adjacent east wall. The second dark grayish brown level extended from $0.25-0.5 \mathrm{ft}$ below the surface and graded from loose to more compact directly above bedrock and contained artifacts, small angular rocks, and some small roots. This layer dates to building construction during the post-Civil War military occupation. The artifacts include ceramics, glass, nails, and a few fragments of burned wood but nothing identifiably nineteenth century.

\section{EXTERIOR NORTH OF}

THE FRONT PORCH

Work north of the porch involved stripping surface vegetation and removing a thin layer of unconsolidated sediment to expose an underlying gravel surface and an associated east-west rock alignment representing a driveway, a stone wall extending from the northeast corner of Room 2 toward Officers' Quarters 8, and possible associated artifacts. Units are of varying shapes and sizes outlining the edges of the gravel layer and the walkway between the rock alignment and the porch. Most of the sediments were not screened.

The dry stone wall was pedestaled to determine its date and its function as a retaining wall or compound wall. The wall is $18.5 \mathrm{ft}$ long and $1.7-3 \mathrm{ft}$ wide, one course high, and varying from two to four rocks wide. The wall was built on dark brown clay loam, the original ground surface, but this contains recent artifacts on or about the same level, indicating recent use of the original military surface. The $0.3-0.4$-ft-thick layer of caliche roadbed aggregate covers part of the wall and postdates it. The wall probably postdates the military period and may have been used as a retaining wall for the yard/driveway area.

An east-west rock alignment extending from about $5 \mathrm{ft}$ east of the highway to the north-south wall at the northwest corner of the building is at the south edge of the gravel scatter. The gravel scatter appears to represent a driveway and the rock alignment its border. The alignment joins a partial 3-x-3.5-ft walkway at the north end of the porch. The step between the walkway and the porch is a rock set in concrete and dating to the civilian occupation.

The extent of the fine-screened gravel bed with regular outline was examined by shovel shaving and clearing vegetation from the north end of the rock wall west to the vicinity of the telephone pole east of the highway and its adjacent utility trench. The gravel scatter extends between the rock wall and the rock alignment.

The grayish brown angular gravel in the $27-\mathrm{x}-18$-ft scatter north of the quarters formed a $0.2-0.3$-ft-thick layer, and the gravel was very uniform, approximately $1 / 4$ inch in diameter, and probably had been sorted commercially. Artifacts recovered include glass, metal, and bone fragments. The underlying caliche roadbed aggregate was $0.3-0.4 \mathrm{ft}$ thick, and the final layer was dark brown clay loam above bedrock.

A 1-x-1-ft test unit was excavated $10, \mathrm{ft}$ west of the porch and $8 \mathrm{ft}$ south of the north end of the porch. Dark brown clayey loam overlay dark brown clay. A 2.5-inch-thick wedge of caliche occurred in the northeast corner of the unit. Bedrock was approximately $0.7 \mathrm{ft}$ below the surface, and a recent tire valve stem cap occurred 
on bedrock in the north end of the unit, indicating this bedrock area had been exposed or prepared for landscape plantings relatively recently.

A 2-x-6-ft trench from the northwest corner of Room 2 was placed to examine the extent of the dark brown clay loam soil with humus and the small angular gravel. The dark brown clay loam was $0.2-0.5 \mathrm{ft}$ thick and overlay the small angular gravel layer about $0.2 \mathrm{ft}$ thick. The gravel surrounded the loam, indicating that this soil was introduced, probably for landscaping purposes. Artifacts indicate mixed nineteenth- and twentiethcentury deposition, with a mid-twentieth-century toy car present just above bedrock. Bedrock was reached at $0.3-0.5 \mathrm{ft}$ below the surface.

\section{ROOM 3 EXTERIOR WINDOW}

A 2-x-6-ft north-south trench was excavated out from the north window of Room 3 to determine the nature of the sediment build-up in the corner of the ell and its possible function as a porch. Sediments were not screened. Work was terminated due to low artifact yield and the presence of bedrock just below the surface. The base of the north wall of Room 3 was directly on bedrock approximately $0.2 \mathrm{ft}$ below the surface. The higher elevation of this area is probably due to a natural bedrock outcrop. There are no indications that a porch or activity area was present.

\section{ROOM 4 EXTERIOR NORTH WALL}

A 1.5-x-4-ft unit extending from the northeast corner of the building along the Room 4 north wall east of the window was excavated. Since bedrock was only 1-2 inches below the surface, no artifacts were present, and the soil was very dark and friable and thus possibly introduced, no further excavation was done in this area.

\section{WALKWAY ON SOUTH SIDE OF STRUCTURE}

An approximately $1.5-\mathrm{x}-1.5-\mathrm{ft}$ unit was placed on the south side of the porch at the juncture with a walkway on the south side of the building. There were 1-2 inches of dark friable soil above 5-6 inches of caliche roadbed. Sterile black clay occurred below the caliche layer. The walkway was built directly on the caliche layer, indicating that it postdates the military occupation.

This walkway, which is very near the surface, was cleared of vegetation and swept, and a swath approximately $1.5 \mathrm{ft}$ wide on either side of the walkway also was cleared in an attempt to locate associated artifacts to date the feature. A large rock was removed from the center of the walkway in front of the Room 3 south window/former doorway, and additional rocks were removed from the part of the walkway southeast of the structure. Sediments beneath the rocks were excavated to bedrock.

The walkway is approximately $2.9-3 \mathrm{ft}$ wide and composed of tabular limestone (average size approximately $0.9 \times 0.9 \mathrm{ft}$ but much variation in size). East of the southeast corner of the building, as the walkway curves slightly toward the north, the south side is edged with brick-sized stones laid on their sides. A stone extends from the walkway toward the building at the southeast corner of the structure and appears to represent the remnants of a walkway or retaining wall at this corner.

In the flagstone walkway south of the quarters, four adjacent rocks were excavated to search for artifacts associated with this feature. The loosely consolidated brown sediment contained a few nondiagnostic artifacts. The sediment below the rocks to bedrock at $0.35 \mathrm{ft}$ below the surface contained a wire nail and nondiagnostic artifacts. Beneath a rock southeast of the building were black sediments $0.1-0.15 \mathrm{ft}$ thick containing a small lens of dark brown gritty sediment and milk glass with orange paint, the latter probably dating to the mid twentieth century. Beneath another rock in this area was a tiny piece of glass. Artifacts under the large rock in front of the Room 3 former doorway were mid twentieth century in age.

\section{Officers' Quarters 10}

Officers' Quarters 10 is on the south end of the row of four captains' quarters built on the east side of the parade ground between the headquarters and the commanding officer's quarters. This officers' quarters is an L-shaped structure containing four rooms.

\section{History}

This quarters was built during the 1868-1872 post-Civil War rebuilding period. The front rooms 
are shown as stone, and the back room (Room 4) was represented as wood on the 1874 and 1875 maps and as a stone room on the 1876 map (see Figures 11-13). Unlike the other captains' quarters, no sink is shown against the back yard wall of Officers' Quarters 10.

A 1920 photograph (Texas Parks and Wildlife Department 1975:237) of the front of this building shows the wood porch, front door on the south end, apparently three windows along the front facade, and the Room 3 chimney on the north end (Figure 34a). There appear to be two sets of front steps at the north and south center of the porch and diverging walkways leading to these, perhaps indicating that one of the windows (shown in the photographs as dark rectangles with no visible detail) actually was being used as a door. A 1934 photograph of the south facade (Texas Parks and Wildlife Department 1975:239) shows three windows (the window in the addition is smaller than the other two), the double-sided chimney between Rooms 1 and 2, and a barbed wire fence south of the building (Figure 34b). A 1936 HABS photograph from the southwest of this structure shows the front door into Room 1, a possible door into Room 3 along the front facade, and the windmill behind the house (Figure 35a). A photograph of unknown source from about this period also shows the possible Room 3 front door, but it is obscured by vegetation, making identification uncertain. A photograph of unknown date and source (marked "for C \& C photo \#12") showing the front of this structure was positively identified by Frances Nixon, who owned and occupied Officers' Quarters 2 during the 1960s and until its acquisition by the state, as the house in which she was born (Figure $35 b$ ). This photograph shows military-period columns and the front wood picket fence. The gate leads to the north end of the house and a former door in Room 3.

When acquired by TPWD in about 1975, the building was being maintained as a private residence. A photograph of the northwest side of the building (Texas Parks and Wildlife Department 1975:242) shows the shed-roofed stone addition on the back and the shed-roofed, wood-framed enclosed porch built inside the ell. Archeological work at the structure took place in 1978 in three exterior areas - the front yard, the south window of Room 1, and the north wall of Room 4 (Figure 36).

\section{Archeological Results}

Two parallel 38-ft-long trenches 10 and $20 \mathrm{ft}$ west of the front porch were placed to search for the walkways shown on the 1920 photograph (Texas Parks and Wildlife Department 1975:237). None of the fill was screened.

Surface grass and $0.1-0.15 \mathrm{ft}$ of rich brown topsoil was scraped to uncover the gravel scatter below. A small subsidiary unit $4 \mathrm{ft}$ north-south by $4.5 \mathrm{ft}$ east-west placed to the north of the walkway confirmed the continuation of the gravels. A flagstone walkway leading to the center of the porch provided access at the time archeological work was done. Excavation revealed two alignments of scattered gravel on either side of the flagstone walkway converging toward the west under the flagstone walkway approximately $30 \mathrm{ft}$ in front of the building. The gravel surface was about $1 / 2$ inch below the cleared surface of loose to slightly compact brown sediment. Sparse gravels occurred in compact brown sediments in the south half of the eastern trench but not in the north half. Each walkway was up to $5 \mathrm{ft}$ wide, and the gravel feathered out on each side. These converging walkways probably correspond to the walkways shown in the 1920 photograph.

\section{ROOM 1 EXTERIOR WINDOW}

A $1.5-\mathrm{x}-8-\mathrm{ft}$ unit was placed adjacent to the westernmost window exterior on the south side of the building. Brown clay in this unit contained window glass and nails.

\section{ROOM 4 EXTERIOR NORTH WALL}

A 1.5-x-7-ft unit was excavated along the north wall of Room 4 and the northeast corner of the main wing. A concrete skirt extended $10.5 \mathrm{ft}$ west from the northeast corner. Dark clayey loam soil had been introduced in this area, and bedrock lay 2-8 inches below the surface. Bedrock was broken on top because of watering landscape plants. A ceramic sherd and a metal file were recovered. No evidence of the military occupation was found in these limited excavations. No temporally diagnostic or military artifacts were recovered. 

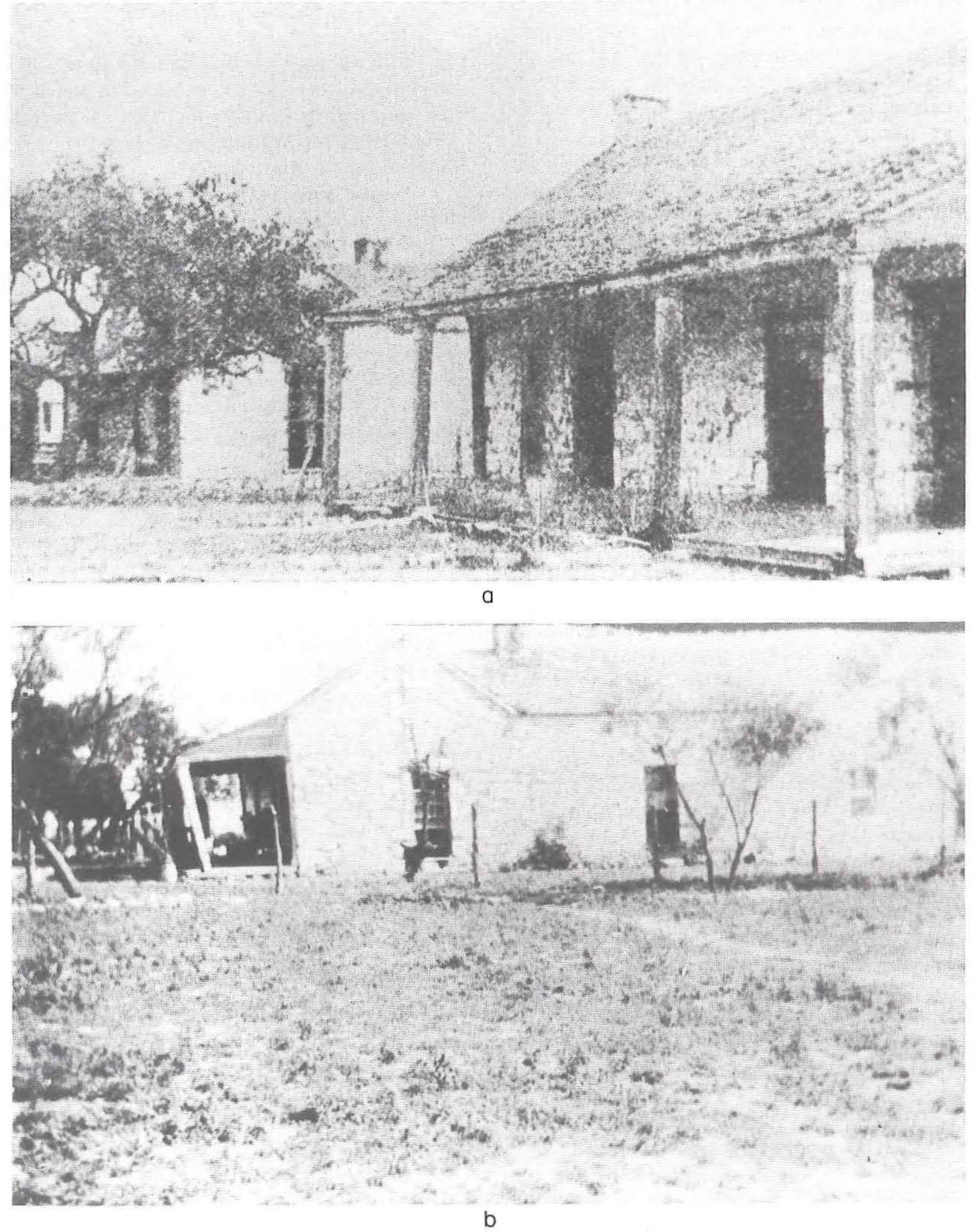

Figure 34. Officers' Quarters 10. (a) Photograph taken in 1920; Officers' Quarters 10 is in right foreground; view is to the northeast (Texas Parks and Wildlife Department 1975:237); (b) photograph taken in 1934; view is to the north-northeast (Texas Parks and Wildlife Department 1975:239). 

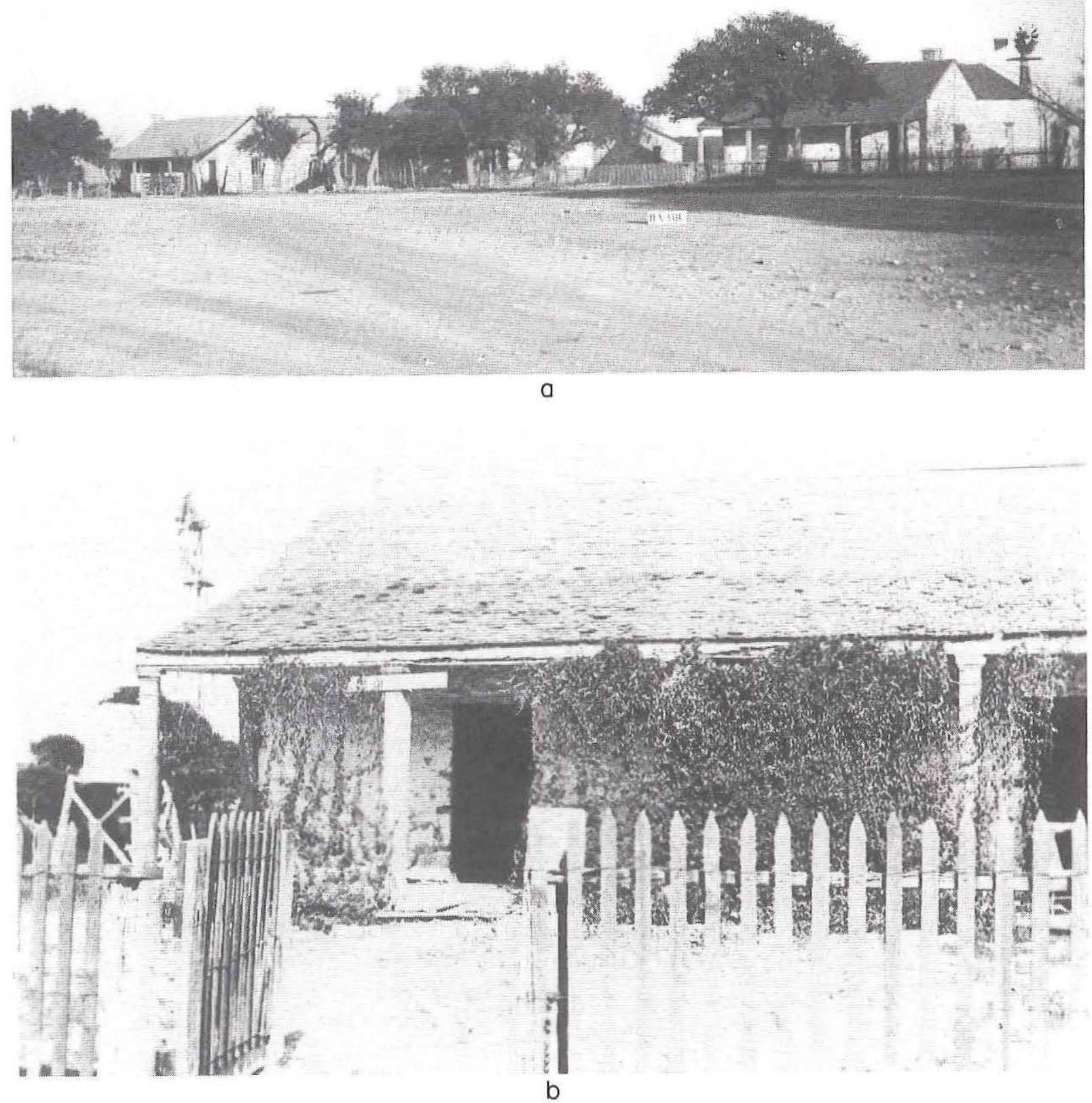

Figure 35. Officers' Quarters 8, 9, and 10. (a) Photograph taken in 1936 showing Officers' Quarters 8, 9, and 10 (from left to right); view is to the east (Texas Parks and Wildlife Department 1975:239); (b) photograph of unknown date showing Officers' Quarters 10; view is to the southeast. 


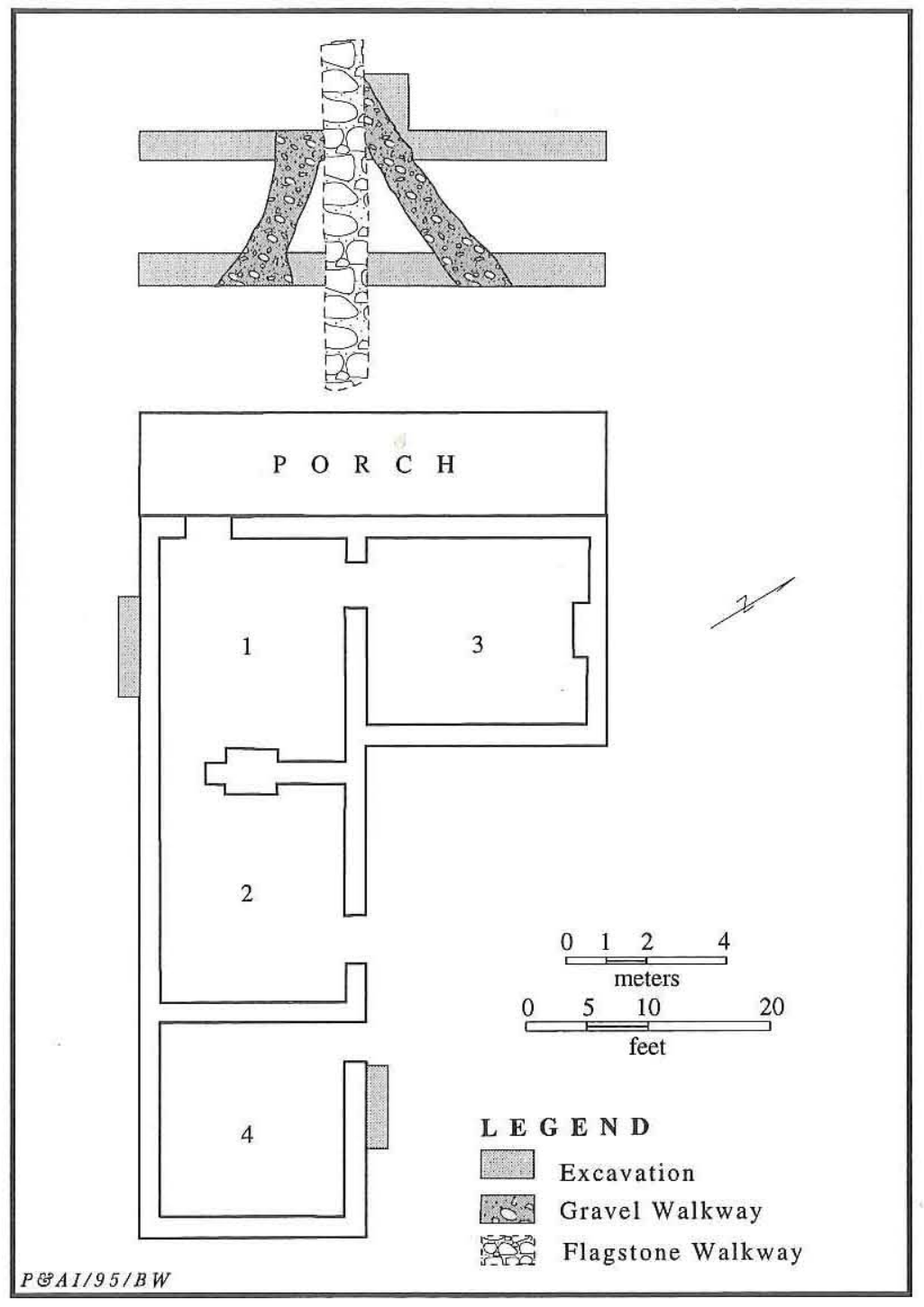

Figure 36. Plan of Officers' Quarters 10.

in front running the whole length. The quarters contained four rooms and a pantry for each field officer (Sharpe and Horton 1875).

The 1874 map of Fort McKavett shows the quarters divided into nine rooms, with four along the front, two in the south wing, and three in the north wing. Steps are present on the north and south ends of the long front porch. Neither the ca. 1871 nor the 1876 maps show a kitchen behind Officers' Quarters 11. A sink is shown behind Officers' Quarters 11 on the ca. 1871 and 1875 maps. The ca. 1871 map shows no internal divisions of the quarters, but the 1876 map shows the main front portion divided into two halves and the rear ells each divided into halves, making six rooms or primary divisions (see Figures 10-13).

Officers' Quarters 11 was southwest of the intersection of two major driveways in the southeast corner of the fort which were cutoffs of the Fort Terrett to Fort Concho roads along the south and east ends of the fort (Fox 1983: 270). The 1875 map (see Figure 12) shows the quarters adjacent to the intersection of the road behind Officers' Quarters 2-6 and beside the hospital with the road along

\section{Officers' Quarters 11}

Officers' Quarters 11 is behind Officers' Quarters 6 south of the parade ground and is northwest of the Commanding Officer's Quarters. The structure is U-shaped with 10 rooms defined during archeological work.

\section{History}

Quarters for the field officers were erected during the rebuilding program of $1868-1872$. The quarters was in a 77-x-18-ft one-story stone building with two ells, each $45 \times 18 \mathrm{ft}$, and a veranda the east side of the main parade ground. In addition, the smaller driveway in front of the Commanding Officer's Quarters intersects with the road along the east side of the main parade ground at the south edge of Officers' Quarters 11. The 1876 map (see Figure 13) shows the same configuration, but with the road along the east side of the main parade ground offset from the quarters' front porch some 5-10 ft. A late 1870 s bird's-eye sketch of the fort (Sullivan 1981:2) agrees with the other maps in the placement of the roads along the east side of the main parade ground, in back of Officers' Quarters 2-6, and in front of the Commanding Officer's Quarters. 
The road and driveway configuration shown on the ca. 1871 map (see Figure 10) differs somewhat from the previously discussed maps. The road along the east side of the main parade ground is offset as on the 1876 map, but the formal road ends at the south end of the quarters and curves to the south-southeast to intersect the road to the spring at the south end of the Commanding Officer's Quarters. The road behind Officers' Quarters 2-6 is shown adjacent to the back yard walls of these quarters, rather than adjacent to the north end of Officers' Quarters 11. This map, which shows curved roads at the fort's perimeter as opposed to the straight roads shown on the other maps, may be a more accurate representation of the roads than the idealized representation on the other maps.

Photographs of the fort taken from the twostory Commanding Officer's Quarters often show Officers' Quarters 11 in the foreground. An 1890 photograph including the northeast corner of the quarters shows the road along the east side of the parade ground some $6-8 \mathrm{ft}$ beyond the edge of the front porch (see Figure 26). The placement of large cobbles outlining the north yard of the quarters and faint ruts in the road indicate that the road behind Officers' Quarters 2-6 was adjacent to the back yard walls of these quarters rather than adjacent to Officers' Quarters 11. The photograph also indicates that the porch roof is hipped.

A 1911 photograph of the field officers' quarters shows the east and north sides of the building with the porch roof missing and the porch flooring present on the east side. The fenestration pattern on the east side is three windows between the south and center doors and two windows between the center and north doors, and on the north side is one window on the front gable end and four windows along the north wing. No window is apparent on the shed-roofed addition outside of the chimney on the west end. The photograph is too blurred for window light patterns to be identified. This photograph shows a chimney on the west end of the north wing and a probable stovepipe vent in the roof of the room to the east.

A ca. 1912 photograph shows the east and south sides of Officers' Quarters 11 with the porch roof missing and the porch flooring deteriorating but visible (see Figure 15). The porch floor extends to the outer edge of the doorways at the north and south ends and appears to be several feet deeper on the north half than on the south half. The three chimneys from the double fireplaces are shown, and in addition there are chimneys at the back end of each wing. Along the front facade there are three $6 / 6$ windows between the south and central doors and two windows between the central and north doors. Along the main south facade there are five $4 / 4$ windows, one window on the shed-roofed addition at the back of the south wing, and no doors.

The ca. 1912 photograph shows the approximately 3-ft-long remnant of a walkway leading from the door to the road along the east side of the main parade ground; it is some $10 \mathrm{ft}$ from the south front door and $3 \mathrm{ft}$ from the edge of the porch flooring and is marked by vertical edging stones bounding a walkway approximately $3 \mathrm{ft}$ wide. The edge of the road appears to be some 3-5 ft east of the walkway remnant. A walkway remnant also appears to be present across from the north door. This 3-4-ft-long remnant, also marked by vertical stones on the north and south edges, begins at the edge of the porch and ends some 3-4 $\mathrm{ft}$ before the edge of the road along the east side of the main parade ground. There is no visual evidence of a walkway leading from the center door to the road.

An unattributed photograph showing the east and south sides of Officers' Quarters 11 postdates 1912 based on the condition of the building, with windows boarded up, a hole in the south wing roof, and deterioration of the central front facade and the porch floor (Figure 37). The building appears to be abandoned by this time, and the yard looks somewhat overgrown with weeds. Only the road in front of the building reflects continued use of this area of the fort. This photograph probably dates to the 1920 s or 1930 s.

When acquired in 1975, Officers' Quarters 11 was a ruin with limestone foundations and low rubble walls (Texas Parks and Wildlife Department 1975:236). Archeological excavations in Rooms $1-7,9$, and 10 and in doorway and walkway areas took place in the summer and fall of 1978 and the fall of 1979 and 1980 (Figure 38). This building was stabilized before archeological excavation took place, so that upper layers of recent mortar and rock fragments from the stabilization overlay the 


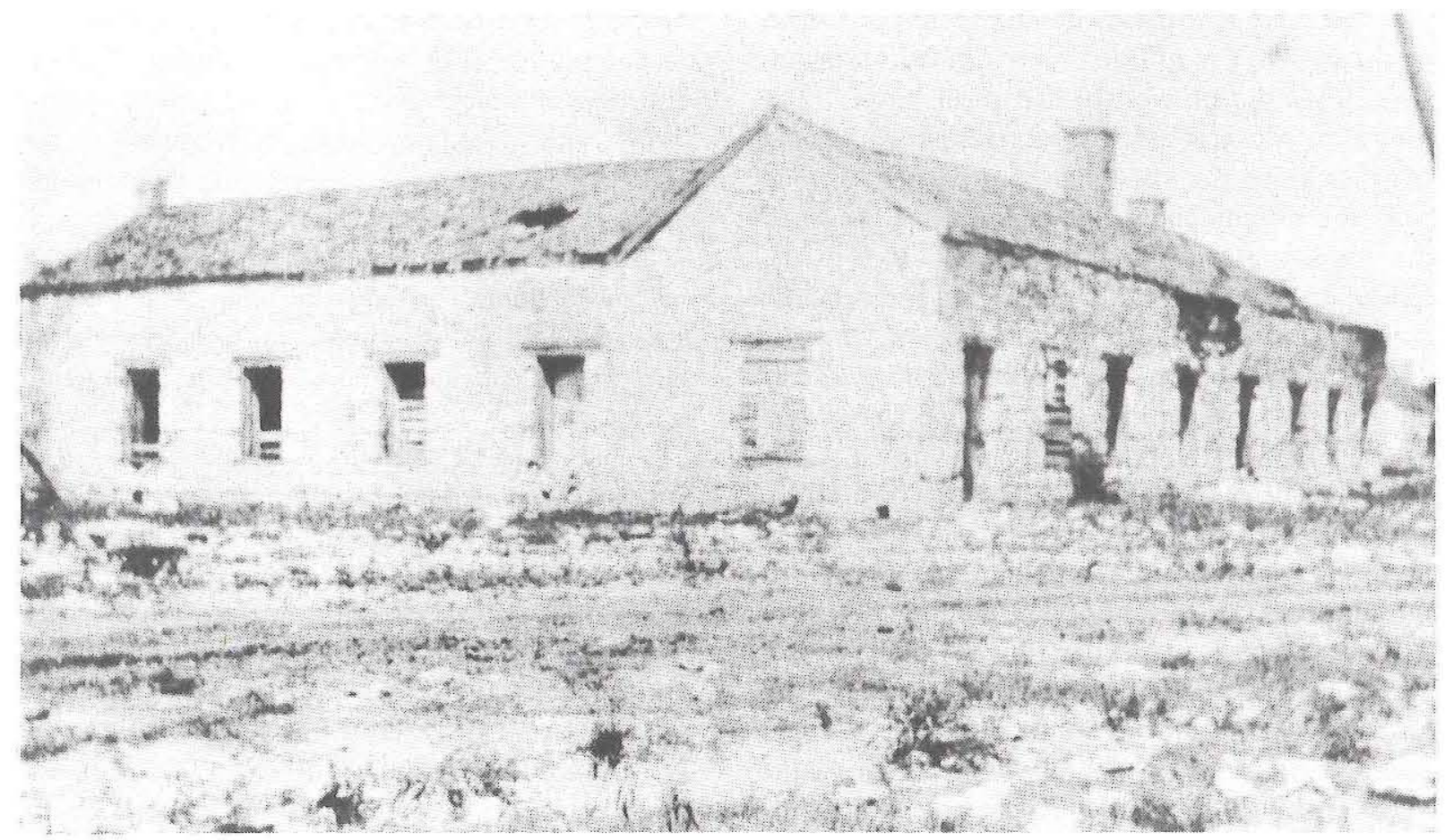

Figure 37. Photograph of unknown date showing the east and south sides of Officers' Quarters 11; view is to the north.

wall fall and occupational debris.

\section{Archeological Results}

\section{ROOM 1}

Excavation in Room 1, the southeast front room, focused on the northwest corner north of the fireplace. A 3-x-5.3-ft unit in this area was placed to search for architectural information and undisturbed deposits associated with the military occupation. Three joist sockets 30 inches apart were located in the west wall between the northwest corner and the fireplace, and fragments of two of the wooden joists were found in situ. The sockets extend $0.6-0.7 \mathrm{ft}$ into the wall, with the two outer ones being adjacent to the north wall and fireplace.

The layer of recent mortar, puddled lime, and rock fragments from stabilization was $0.25-0.4 \mathrm{ft}$ thick. Below this was a layer of wall fall consisting of rocks, wall plaster, and mortar and sand $0.5-1.0 \mathrm{ft}$ thick. The lower part of this layer was dry screened through $1 / 4$-inch mesh, and most artifacts were recovered from this layer. These include cut nails; colorless, brown, and green bottle glass; charcoal; burned mortar; and one each clay marble, glass marble, and shell button. The lowest layer was dark brown clay loam and bedrock.

\section{ROOM 4}

The east half of the double fireplace in the west wall was excavated to search for undisturbed fireplace deposits and to expose fireplace construction. The approximately $0.7 \mathrm{ft}$ of upper fill was dry screened through $1 / 4$-inch mesh. There were traces of charcoal throughout the fill. This upper fill contained lenses of grayish tan ashy fill with charcoal flecks, small pieces of mortar, and chunks of limestone from wall fall and deterioration of the chimney. A 0.1 -ft-thick lens of relatively undisturbed ash above the underfire was excavated and screened separately.

A 3-x-5-ft unit was excavated in the'northwest corner to expose the doorway area east of the northeast corner unit in Room 5 and north of the fireplace in Room 4. The north side of the doorway was plastered at the original position of the vertical door frame member. No plaster was found 


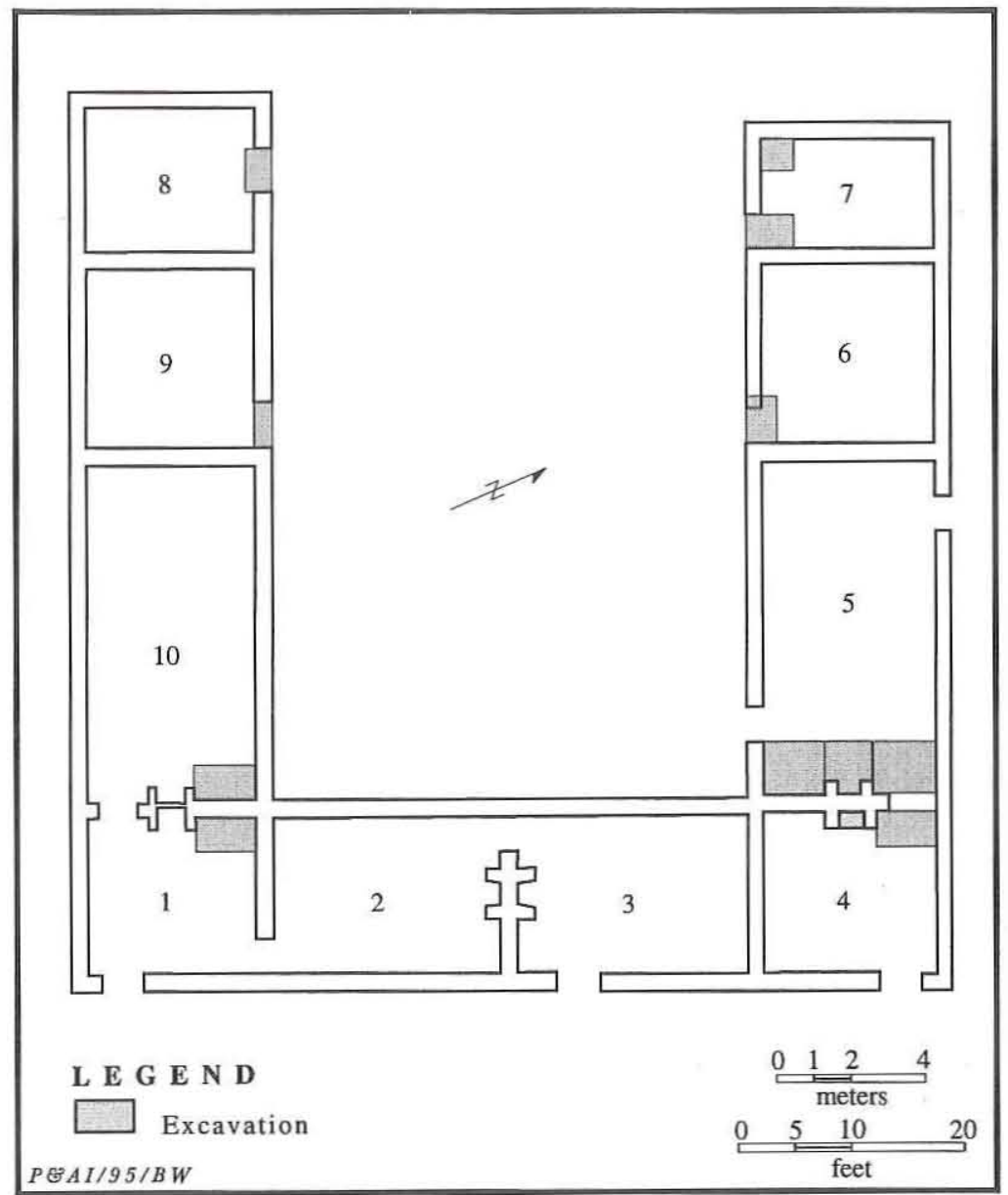

Figure 38. Plan of Officers' Quarters 11.

on the south side of the doorway, but nailers were found for the floor molding. Artifacts including abundant large rocks and plaster as well as bottle glass, nails, a staple, and wood were found in upper wall fall.

\section{ROOM 5}

The east side of Room 5 was excavated with a 5-x-5-ft unit in the northeast corner, a 4-x-5-ft unit in the fireplace area, and a $5-\mathrm{x}-5.5$-ft unit in the southeast corner. Two in situ north-south joist remnants were found along the east wall. A third wooden support was laid east-west to frame the plastered north edges of the limestone fireplace coving and hearthstone in the northeast unit. The greatest concentrations of artifacts tended to occur between the brown to reddish brown loam with frequent mortar and the underlying dark brown clay or at the top of the latter layer.

The unit in the northeast corner north of the fireplace was excavated to examine a possible window location based on broken glass, to examine the doorway between Rooms 4 and 5, and to trace possibly structural decayed wood. The upper reddish brown sandy loam contained painted plaster, mortar, and rocks of various sizes. Many artifacts were found in this wall fall layer. The northwest half of the unit was dominated by bottle and window glass, and the southeast half of the unit was dominated by nails, metal, and wood. Sediments from within $1.5 \mathrm{ft}$ of the north wall were excavated and screened separately from those from $1.5-3.5 \mathrm{ft}$ south of the north wall to examine glass fragment distributions. Wood fragments and cut nails were frequent in the upper dark brown/black clay representing the original surface. Artifacts recovered, in addition to window and bottle glass, are twentieth-century table glass, nails, metal container lids, wire, phonograph record fragments, and automobile parts.

The unit in the fireplace area contained nail concentrations in front of the fireplace covings, probably deriving from the original wood mantles or nailers, and in front of the hearthstones, probably deriving from wood framing around the fireplace and dating to room occupation. A layer of mortar and plaster fragments occurred on the north half above the hearthstone, and charcoal flecking and chunks were common above the south half of the hearthstone. On the other hand, the bottle glass, tin cans, wood, and nails in front of the hearthstones probably postdate room occupation and relate to trash disposal or stabilization work in the room based on the loose rocky sediments in this area.

The unit in the southeast corner of the room south of the fireplace exposed the plastered east 
wall and the adjacent north-south joist. Sediment was brown to orange loam overlying dark brown clay. With the exception of the joist and plaster along the east wall, the rock, wood, nails, and tarpaper probably derived from wall fall, trash disposal, or stabilization work and are not likely in situ structural remains.

\section{ROOM 7}

Two units were established along the 9-ft-long south wall of this room. The south wall contained only a single layer of white plaster, but the east wall contained alternating layers of white and gray plaster with an earlier reddish brown coat.

The 4.5-x-3-ft unit in the southeast corner of this room inside the door contained five layers. Beneath the wall fall layer was a $0.20-0.27$-ft-thick layer of frequent mortar and limestone in a mottled orange and black clay. Below was a $0.32-0.45-\mathrm{ft}$ thick layer of loosely consolidated grayish brown sediment with artifacts present at the contact with the wall fall layer. Both cut and wire nails and an 1878 dime occurred in this layer. The contact between these two surfaces was very distinct, with increasing white lime content above the contact possibly representing melted plaster, and rocks had been pressed into the lower brown surface. Below was a $0.21-0.26$-ft-thick layer of red clay and a layer of white ash with small stone chips at the surface along the wall.

The 3-x-3-ft unit in the southwest corner also contained five layers. The upper white mortar layer was ca. $0.15 \mathrm{ft}$ thick, and the grayish brown sediment below this contained more artifacts than the other layers and was $0.32-0.53 \mathrm{ft}$ thick. The upper orange clay beneath contained occasional small rocks and no apparent artifacts and was ca. $0.33 \mathrm{ft}$ thick. A lens of white ash within the orange clay was $0.15 \mathrm{ft}$ thick. The lower orange clay contained many rocks ca. $0.1 \mathrm{ft}$ in diameter.

\section{ROOM 10}

A 3-x-5.5-ft unit was placed in the northeast corner of this room north of the fireplace to expose architectural details and to search for artifacts associated with the military occupation. Three joist sockets were found in this corner, one in the east wall just north of the fireplace (for an eastwest joist) and two in the north wall $3 \mathrm{ft}$ apart (for north-south joists). Wood fragments are associated with each of these sockets.

The first two fill layers, a recent white mortar $0.1-0.25 \mathrm{ft}$ thick and wall fall consisting of rock rubble, mortar, and plaster $0.3-0.7 \mathrm{ft}$ thick in a loosely consolidated brown sediment with decomposed wood, were removed without screening, but the probable original surface layer of friable dark grayish brown clay loam with wood fragments and angular rocks beneath was dry screened through $1 / 4-$ inch mesh. Decomposed wood from joists extends from the wall fall into this lower layer.

\section{DOORWAYS}

A 3-x-4-ft unit was placed in the south doorway of Room 6 in the north wing. The threshold stones were mortared, and the sill stone was not complete. The upper wall fall contained mortar and a few artifacts. The dark brown clay with small glass fragments and nails overlay a sandy orange layer containing mortar and small, thin angular rock chips but few if any artifacts extending $1.5 \mathrm{ft}$ from the east wall of the room. The underlying dark brown clay was full of bedrock and represents sterile subsoil.

A 4-x-1.5-ft unit was placed in the north doorway of Room 9 in the south wing. The relatively small rocks comprising the threshold were laid with abundant reddish brown mortar to create a smooth surface. The top layer below the sill rocks was loosely consolidated dry plaster-andmortar-filled sediment with small rock fragments at the base of wall fall rubble cleared from the room. The second layer was compact dark brown clay.

The north doorway of Room 8 was excavated with a $3.65-\mathrm{x}-2.6-\mathrm{ft}$ unit. The threshold stone was $1.1 \mathrm{ft}$ wide. A mortar bed with rocks possibly representing an earlier threshold was present adjacent to the threshold. A ca. 0.5-ft-layer of wall fall containing white plaster with very few artifacts overlay a layer of loose brown sediment with large limestone fragments embedded in its surface and many artifacts.

\section{NORTH WALKWAY}

Nine units (of unstated size) were placed in the walkway area east of the north front door. The first unit was centered over four vertical edging 
stones forming the south border of this walkway remnant visible in the ca. 1912 photograph. The south halves of five of these units were outside the walkway. The lack of edging stone remains on the north border of the walkway may be due to disturbance in this area. East of the edging stones in several units was an unbounded gravel surface probably representing the edge of the road along the east side of the main parade ground. The western $3 \mathrm{ft}$ of these units apparently lay under the porch. A porcelain doll's foot was found in one unit, and a clasp and military button in the fill of another. A lime mortar pit in the northeast corner of one unit probably was very recent based on the buried grass surface below the pit. Another small pit occurred in the southwest corner of another unit. The depth of fill over the walkway increased with proximity to the quarters. At the contact between the fill and the walkway surface, there was a tremendous amount of broken bottle glass and cut nails.

\section{BARRACKS 2}

Barracks 2 is in the northwest corner of the main parade ground north of Officers' Quarters 1 . This structure is linear in plan with three rooms.

\section{History}

This barracks was described in 1875 as an $80-\mathrm{x}-20$-ft stone building. All of the barracks were one story, $10 \mathrm{ft}$ high to the eaves, with a space of 5 to 8 inches left open at the eaves the whole length of the building to afford sufficient ventilation allowing about $485 \mathrm{ft}^{3}$ of air space per man. The dormitories were fitted with single iron bedsteads, and each bed had a wooden chest projecting over the head of the bunk with a shelf at the top (Sharpe and Horton 1875).

The ca. 1871 map of Fort McKavett depicts a stone building with a porch along the east side (see Figure 10). The 1874 and 1875 maps show Barracks 2 as a three-room structure with a porch on the east, facing the parade ground, a backyard on the west, and two possible frame rooms, one on the north and one on the south end (see Figures 11 and 12). It is not clear if these frame rooms were ever built since the local lumber was not good quality for construction and few frame structures appear to have been built at the fort during the military period. The 1876 map shows this as a three-room stone building with a back yard on the west (see Figure 13). The occupants of this barracks may have shared the sinks and kitchen behind Barracks 1, or there may have been latrines and company mess kitchens not depicted on the maps. Barracks 2 was accessed by walkways along the west and north sides of the main parade ground and by a walkway along the south end of Barracks 1 and 2 .

The barracks was a ruin when the fort property was acquired by TPWD in 1975 . The ruins of this barracks show in the 1890 photograph of the main parade ground taken from the Commanding Officers' Quarters (see Figure 26). The ruins of a chimney on the south end of the quarters was the only remnant of this building still standing in 1890. Archeological work in the middle and south rooms took place in the fall of 1980 .

\section{Archeological Results}

Three 1-x-5-ft units (Units 1-3) were excavated along the inside of the north half of the east wall of the middle room, and one 1-x-4-ft unit (Unit 5) was excavated along the south end of the west wall of this room in a search for undisturbed deposits (Figure 39). Brown loam was found in both Units 1 and 2. Glass, nails, and buttons were recovered from Unit 1.

Unit 2 was adjacent to a portion of the east wall where foundation stones were missing. At approximately $0.3-0.6 \mathrm{ft}$ below the surface, compact pinkish gray mortar and sand was found in the south half of the unit and grayish white ash in the north half of the unit. Below was a layer of darker loosely consolidated sediment containing more artifacts, including a military button, glass, and lead balls, and terminating at bedrock. Other artifacts include bottle and patinated window glass, nails, and shell buttons.

Unit 3 extended south to a previously excavated unit at the center of the east wall in the middle room. The compact mortar layer in. Unit 2 was present in the northern two-thirds of this unit and contained frequent window glass and paint chips and a military button. The south end of the unit contained a much darker brown sediment with mottled paint and plaster flecks and few artifacts grading to sterile clay with bedrock. An infantry cap insignia was found on the original ground 


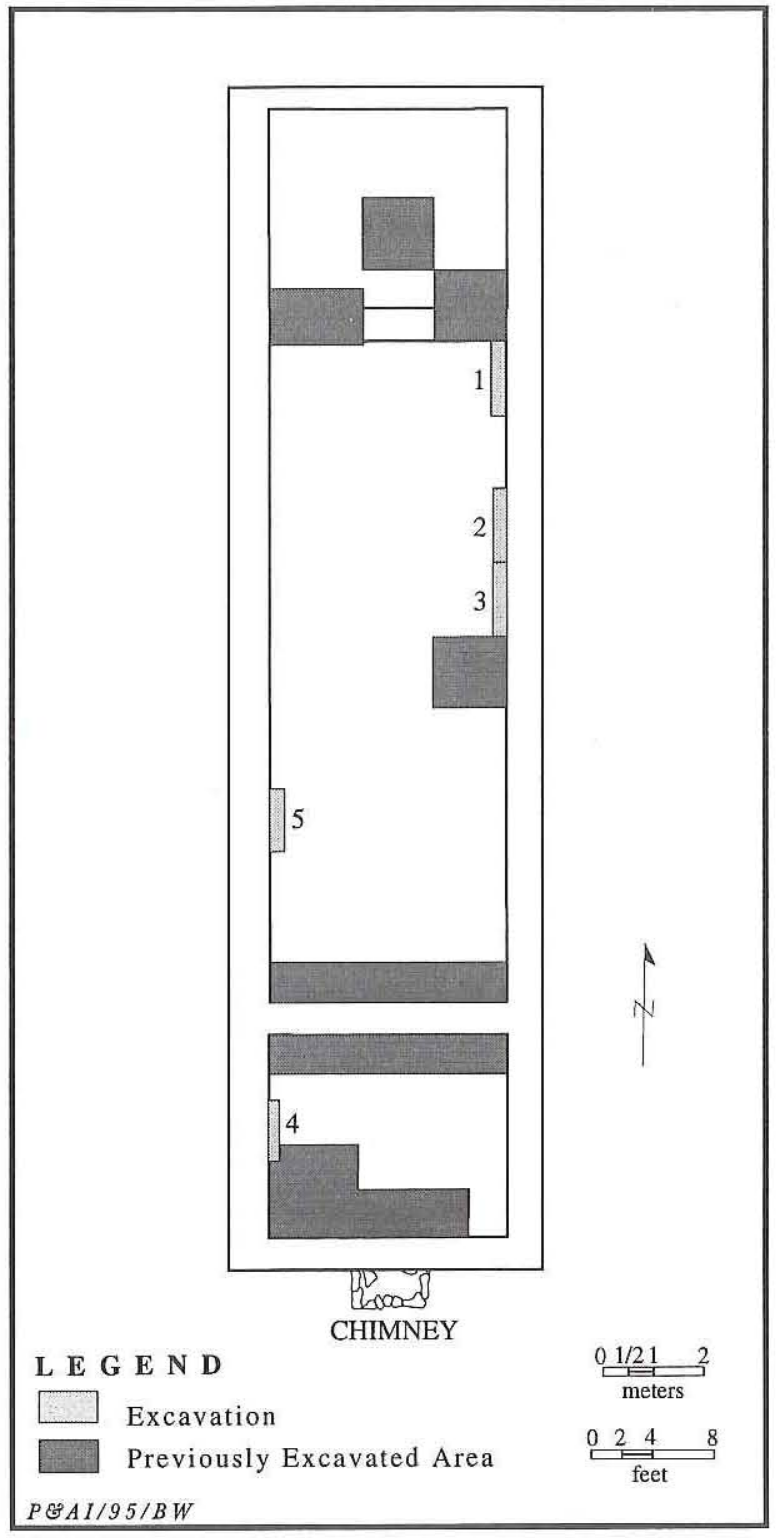

Figure 39. Plan of Barracks 2.

surface in the extreme north end of the unit.

Unit 5 at the south end of the west wall was excavated in a search for undisturbed deposits. The south end of the unit was undisturbed, but the north end contained organic materials at the top and krotovina in the plaster and paint layers from rodent burrowing. The west wall foundation was set in a trench. A loosely consolidated light brown topsoil with root zone overlay wall fall consisting of compact and friable pink mortar, plaster, and whitewash/paint flecks in a sandy matrix. An 1868 silver nickel was found at about $0.64 \mathrm{ft}$ below the top of the remaining foundation and $1.1 \mathrm{ft}$ from the south end of the trench. A lead ball and a black glass button were found in the southern half of the trench at the top of the original ground surface.

A 1-x-4-ft unit (Unit 4) was excavated along the west wall of the south room, overlapping with an earlier unit in the southwest corner of this room. Sediments were screened through 1/4-inch mesh. The west wall of this room measures $13.8 \mathrm{ft}$, and the foundation was set in a trench lined at its bottom with pink mortar. Rocks in the remnant of the west wall that had been buried were discolored differently from those that had been exposed. Measurement of the discolored rocks indicated that up to $0.45 \mathrm{ft}$ of deposit already had been removed from against the wall before excavation of this unit.

Below loose topsoil and a root zone was a layer of loose dark brown and tan sandy sediment with small embedded rocks. A veneer of $0.03-\mathrm{ft}-$ thick pink mortar extending $1.5 \mathrm{ft}$ south from the northwest corner overlay the original ground surface adjacent to the wall. The wall trench tapered from $0.3 \mathrm{ft}$ wide in the dark brown and tan sediment to $0.1 \mathrm{ft}$ wide at the top of the original ground surface. The original ground surface consisted of dark brown clay containing small rocks. Few artifacts were present.

\section{COMMISSARY STOREHOUSE}

The commissary storehouse is at the center of the north end of the fort between the quartermaster buildings and stables. The structure is T-shaped with two rooms in the main front (south) wing and two in the back (north) wing.

\section{History}

After 1868 a picket structure near the quartermaster's stables area north of the parade ground housed the commissary storehouse. In 1875 the stone commissary storehouse in this same area was $120 \times 22 \times 10 \mathrm{ft}$ and built on a slope with the floor raised $4 \mathrm{ft}$ above the ground and a $50-\mathrm{x}-30-\mathrm{ft}$ ell. The raised floor of the storeroom probably accommodated a subfloor or cool storage underneath. The main wing contained a large storeroom and a small office. The ell contained a small room with shelving and a counter for issuing materials (Texas Parks and Wildlife Department 1975:261). 
The ca. 1871 map of Fort McKavett shows the commissary and quartermaster buildings and blacksmith and carpenters shop southeast of the stables in a configuration different from any other map; none of the buildings is T-shaped or in the location corresponding with the excavated structure (see Figure 10). The 1874 map shows this building, erroneously labeled "Company Stables," with the main wing built of stone with two rooms (the office on the east end) and the back wing and a front porch built of wood, with a small loading dock, porch, or addition at the southwest corner of the back wing (see Figure 11). The 1875 map shows the commissary store in the same configuration as the 1874 map but with all wings and additions of stone construction except for the front porch (see Figure 12). The 1876 map (see Figure 13) shows the commissary store in the same configuration in stone as the 1875 map combined with the small room on the east end of the main wing and the wooden curved or bay front porch as on the 1874 map.

This building was in ruins when the fort property was acquired, and only the back wing wall lines were discernible (Texas Parks and Wildlife Department 1975:261). Excavation in the main and back wing areas took place in the fall of 1980.

\section{Archeological Results}

Twenty-four units of varying sizes were excavated along the front and back walls of the main wing, along the walls of the east and west rooms of the back wing, and in the southwest corner of the back wing in search of a loading dock, porch, or addition (Figure 40). The back wing wall remnants were standing above the ground surface.

\section{FRONT WING}

Units 8 and 9 were placed on the north and south sides, respectively, of the front wall of the main wing. The deposits on either side of the wall were completely different. Unit 8 was a 2-x-2.2-ft unit placed inside the structure, and Unit 9 was a $2.3-\mathrm{x}-2-\mathrm{ft}$ unit including the front wall and $1.5 \times 2 \mathrm{ft}$ on the outside of the wall. The top layers in both units were a grass root zone containing few artifacts, including ceramic and glass fragments, and a darker-colored topsoil containing glass fragments, nails, and a can lid. The third layer occurred only in Unit 8 and consisted of mottled dark and light brown sediments containing one ceramic sherd and a few nails. The fourth layer was mortar, sediment, and rocks with frequent artifacts, including ceramics, glass jar and window glass fragments, bottle tops, nails, and wire. This deposit in Unit 9 was a dense layer of mortar. Mortar remained predominant in the final layer in Unit 8, a compact dark brown sediment with mottled pink mortar and white sand and a $1-\mathrm{x}-1-\mathrm{ft}$ concentration of mortar against the wall. This relatively deep $(0.2-0.4 \mathrm{ft})$ layer contained plaster with whitewashed surfaces, frequent bottle and window glass and nail fragments, as well as metal scraps and a few ceramic sherds. This layer terminated at bedrock overlain with some mortar remnants. The final layer in Unit 9, however, contained little mortar and few artifacts.

Unit 10 was a $2-\mathrm{x}-1.5$ - $\mathrm{ft}$ unit placed against the center of the wall shared with the back wing at 
the intersection of the T. The top layer was a dark humic sediment $0.3-0.4 \mathrm{ft}$ thick mixed with rocks and vegetation. The second layer was pinkish gray sediments $1.2 \mathrm{ft}$ thick containing rocks from wall fall and mortar, including many pieces with painted surfaces. Excavation terminated at a compact dark sediment $1.6 \mathrm{ft}$ below the surface. Near the base of the excavation, fragments of a modern 7-Up bottle appeared.

Units $11-13$ and 20 were placed along the back wall of the main wing. Unit 11 was a $2-\mathrm{x}-3-\mathrm{ft}$ unit extended $1 \mathrm{ft}$ to the south containing three layers. The first layer was a root zone, the second a dark brown topsoil, and the third a pinkish orange layer in the south end terminating in the expected back wall foundation remnant. The unit was extended $1 \mathrm{ft}$ to the south to define the inside edge of the back wall. Only the upper root zone and dark brown topsoil layers of Unit 12 were excavated before the wall was found in Unit 11 , which resulted in termination of excavation in Unit 12. No wall was found in Unit 13, a 2-x-2-ft unit containing root zone and clay layers and terminating at bedrock $1 \mathrm{ft}$ deep.

\section{SOUTHWEST CORNER OF THE INTERSECTION OF THE T}

Units 18 and 19 were paired 2-x-2-ft units in the vicinity of the possible porch, loading dock, or addition at the southwest corner of the intersection of the T. The top layer in Unit 18 was root zone and topsoil. The second layer was grayish brown clay topsoil with sand. A thin layer of topsoil occurred over a thin layer of gray sediment, which in turn overlay a pink to burnt orange mortar bed at $0.2 \mathrm{ft}$ below the surface in the northern $0.6 \mathrm{ft}$ of the unit. This mortar bed, which was not harder than the surrounding sediments, may represent the remnants of a pier footing. Soft mortar-colored sediments in the southern part of the unit contained concentrations of plaster and mortar remains at $0.35 \mathrm{ft}$ below the surface that also may represent pier supports. The difference in depth between the mortar bed and mortar/plaster concentrations may indicate two different construction episodes or foundations for wooden steps and for piers, for example. A 2-x-2-ft mortar concentration was found in Unit 19.

Units 14,16 , and 17 were placed in the outside southwest corner of the back wing where it abutted the front wing in a search for the porch, loading dock, or addition indicated by the 1874 and 1876 maps (see Figures 11 and 13). Unit 14 was a $2-\mathrm{x}-2-\mathrm{ft}$ unit containing four layers, with the lower two divided into sublayers on the west and east ends. The first layer was a root zone, and the second layer was topsoil. Below the second layer, the west one-third of the unit was dark in color, similar to the topsoil above, and the east two-thirds of the unit was light gray ash. The lower sediments in the west one-third of the unit were a dark brown clay in Level $3 \mathrm{~A}$ and a similar sediment lighter than topsoil in Level 4A. Level 3B on the east end was gray ashy sediment, and Level 4B was light sediment containing mortar fragments and terminating on bedrock.

Unit 16 was a $2-x-2-f t$ unit containing three layers. The first two layers were a root zone and topsoil as in Unit 16. The third layer contained some pink mortar in the southwest corner and terminated on bedrock.

Unit 17 was a 2 -x-2-ft unit excavated to further define pink mortar present at the surface. The pink mortar and small rock concentration was approximately $2 \times 2 \mathrm{ft}$, extending into adjacent Units 14 and 16, and may represent the remains of a pier support for a porch or loading zone. The top two layers in Unit 17 consisted of a grass root zone and topsoil. Beneath was an ash lens overlying dark brown sediment. The final layer was very dark brown sediment above bedrock. Artifacts recovered are glass, nails, tacks, clothespin springs, metal scraps, and wire.

\section{BACK WING}

Units $1-6$ and $21-24$ were placed in the east room of the back wing, Unit 7 was placed at the southeast corner at the intersection with the front wing, and Unit 15 was placed at the exterior of the west room. The east room was $13 \mathrm{ft}$ wide (eastwest).

Modern trash, ash, vegetation, and limestone wall rubble were removed to expose the present ground surface before excavation of Unit 1 in the northeast corner. In situ mortar was present in the remnants of the north wall. The first layer in Unit 1 was wall rubble containing window glass, ferrous metal, and nails in a loosely consolidated brown sediment. The second layer consisted of a higher density of limestone $0.8 \mathrm{ft}$ or smaller and mortar 
washed from the walls and accumulated in the northeast corner, along with two puddles of mortar and very small fragments elsewhere in the layer. Artifacts include a high density of ferrous metal, including nails. The third layer contained bedrock outcropping in dark brown sediment. The upper portion of the third layer contained nails, an iron strap, and bones, and the lower portion was sterile.

Four units (Units 2, 6, 5, and 3) were placed in an east-west trench in the center of the east room to examine room stratigraphy. Unit 2 was a $3-x-3-f t$ unit on the east side of the northern portion of that crosswall. Size-sorted wall rubble including large rocks above small rocks mixed with recent trash, ash, and charcoal was removed before excavation and dry screening through $1 / 4$-inch mesh began. The top layer was noncompact grayish brown sediment $0.26 \mathrm{ft}$ thick containing frequent rocks and recent trash. The second layer was pink sediment $0.28 \mathrm{ft}$ thick mixed with mortar and plaster containing a single coat of whitewash, frequent roots, and a few nails. This layer appears to represent materials washed from the wall. The third layer was grayish brown sediment $0.09 \mathrm{ft}$ thick with many roots and wire nails. The fourth layer was white-flecked grayish brown sediment $0.03-0.07 \mathrm{ft}$ thick at the toe of the mortared but not laid limestone at the foot of the wall. At the foot of and perpendicular to the wall was a $91 / 4-\mathrm{X}-5 \frac{1}{2}-\mathrm{X}-2^{3 / 4} / 4$-inch brick, possibly a firebrick, resting on the surface of the mortared bedrock. The fourth layer terminated at bedrock.

Unit 6, a 2-x-3.4-ft unit adjacent to Unit 2, contained five layers (Figure 41). The top layer consisted of ca. $0.15 \mathrm{ft}$ of light-colored ash with glass and nail fragments. The second layer was ca. $0.1 \mathrm{ft}$ of black to very dark brown sediment with ash and glass and nail fragments. The third layer was reddish brown sediment $0.1-0.2 \mathrm{ft}$ thick with glass, nails, a metal strap, and bones. The fourth layer was about $0.3 \mathrm{ft}$ thick. Its upper portion was reddish brown sediment with mortar flecks; this upper layer contained a high density of nails and few glass fragments. The lower portion of the fourth layer contained a concentration of pink plaster in the western end of the unit and mottled plaster elsewhere; this lower layer contained glass and nails. The final layer was about $0.3 \mathrm{ft}$ of dark brown sediment with a continuation of the mortar puddle from Unit 2 at the west wall of this room. This layer contained many nails, bottle glass, and a metal tool and terminated on bedrock.

Unit 5 was a 2-x-3.4-ft unit adjacent to Unit 6. The top two layers were identical to those in Unit 6; together, they were $0.35 \mathrm{ft}$ thick across most of the unit, although the bottom of the second zone rose to the north such that both zones pinched out a short distance into Unit 3. The third layer consisted of ca. $0.25 \mathrm{ft}$ of light reddish brown sediments with tiny paint and mortar fragments and few artifacts overlying bedrock and resembled the third and fourth layers in Unit 6.

Unit 3 next to the east wall of the east room contained dense wall rubble above ca. $0.4 \mathrm{ft}$ of reddish brown sediment (the third layer in Units 5 and 6). Artifacts include glass fragments, nails, and scrap metal.

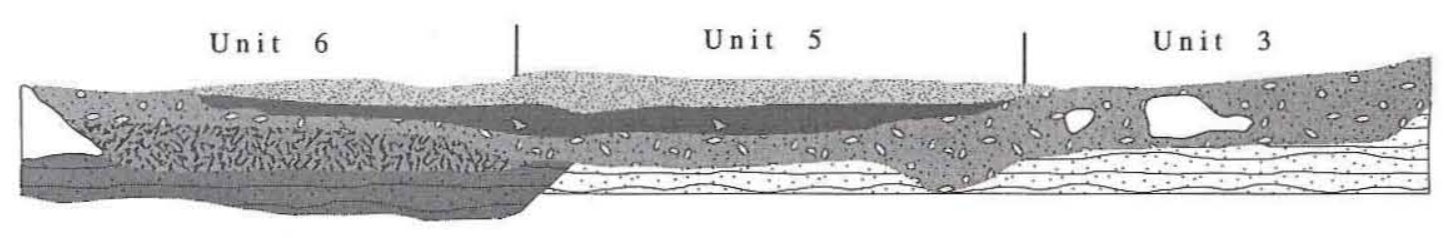

L E G E N D

Ash
Black To Very Dark Brown
Reddish Brown
Reddish Brown Mortar \& Plaster
Dark Brown
Bedrock
AI/95/BW
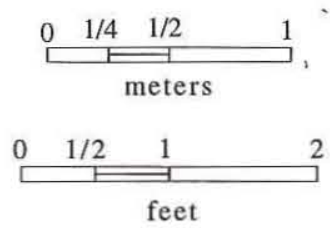

Figure 41. North profile of commissary storehouse, Units 6, 5, and 3. 
Unit 4 was placed along the north-south wall dividing the back wing into eastern and western rooms. Unit 4 was a $3-x-3-\mathrm{ft}$ unit on the east side of the southern portion of the crosswall. All sediments were dry screened through $1 / 4$-inch mesh. The first layer was loosely consolidated materials containing modern glass. The second layer consisted of organic dark brown sediments containing modern glass and a few nails. A deep rodent or root disturbance containing loosely consolidated clay, vegetation, and artifacts occurred against the wall in this layer. The third layer consisted of mottled pink sediments and contained small pebbles. The fourth layer contained brown clay with mottled orange to pink and black sediments containing charcoal. The fifth layer was very dark brown to black sediment above exfoliating bedrock.

Units 21-24 were 1-x-3-ft segments of a 1-ftwide north-south trench to explore the depth of sediments above bedrock in the east room. The bedrock in this area was not covered with topsoil, the original clay ground surface, or exfoliating pebbles as in other units in this structure. Sediments were muddy and were not screened, although artifacts were collected. Unit 21 contained shallow sediments over bedrock exposed at the surface. Unit 22 was $0.2 \mathrm{ft}$ deep. In Unit 23 , sediments were $0.2 \mathrm{ft}$ deep in the south and $0.5 \mathrm{ft}$ deep in the north. Unit 24 sediments were the top root zone, brown sediments, and mortar and plaster above bedrock.

Unit 7 was a $2-\mathrm{x}-2$-ft unit placed at the southeast corner of the back wing. The back wing south wall was $0.65 \mathrm{ft}$ deeper than the east wall, probably indicating that this south wall was part of the original south wall of the main wing, with the north, east, and west walls of the back wing added later. Wall fall consisted of pinkish gray sediments removed to the level of the lower portion of the partially standing wall. Dark and organic topsoil mounded (possibly bulldozed) against the wall was removed, and a $1.15-\mathrm{ft}$ east-west by 1.65 -ft north-south section along the east edge of the corner was excavated down to a large flat rock at $0.65 \mathrm{ft}$ below the surface. Deposits were loosely consolidated and included frequent large pieces of painted or whitewashed mortar with scoring, possibly like that which occurred on the exterior walls of the New Hospital. The second layer was a dark sediment containing a clay marble at the surface and few artifacts.

Unit 15 was a $2-\mathrm{x}-2-\mathrm{ft}$ unit outside the north end of the west exterior wall of the back wing. The first layer was a homogeneous topsoil $0.17 \mathrm{ft}$ thick. The second layer was a slightly lighter color with frequent pebbles and was $0.35 \mathrm{ft}$ thick above bedrock. Artifacts include bottle and window glass and nails. In the west end of the unit, a thin lens of mortar-colored sediment overlay a thin layer of black sediment on top of bedrock.

\section{OLD HOSPITAL}

The Old Hospital is in the southwest corner of the fort, south of Officers' Quarters 2 and west of the Schoolhouse. The Old Hospital buildings are arranged in a $\mathrm{T}$ plan with additional outbuildings outside the plan.

\section{History}

The Old Hospital complex was begun in $1852-1853$ as a hospital and finished and occupied as officers' quarters from 1854 to 1859 . Construction materials for the various buildings are confusing, as the archeological and oral history results for some buildings conflict with the materials shown on the historical maps. Actual materials used are pointed out below. In 1868 only the kitchen walls remained. The post surgeon stated that this stone building was rebuilt and converted into a dispensary and storeroom, each room being $14 \times 20 \mathrm{ft}$ and $10 \mathrm{ft}$ high. Two tents sewn together, framed, and floored served as a ward until the erection of a $20-\mathrm{x}-50$-ft and 15 -ft-high boardand-batten building at the front of the complex in January 1869. A 20-x-18-ft cedar-picket kitchen plastered with mud was behind the dispensary. An 11-x-18-ft stone building was repaired for use as a three-bed ward. These buildings were used as officers' quarters after the new stone hospital was completed in January 1874 until troops vacated the post (Texas Parks and Wildlife Department 1975: 201).

The ca. 1871 map of Fort McKavett (see Figure 10) labels the complex as a hospital with a a wire-fenced (?) yard containing six buildings and one outbuilding outside the southwest corner of the fenced area. The front building is of stone, has a full front porch, and provides access to the complex. Behind it are three buildings - the first 
shown as stone but thought to be frame based on oral history and architectural evidence, the second picket, and the third frame. To the east of the last two buildings is a frame building with a porch on the south, and to the west of the last two buildings are a small stone building just inside the fence and a tiny stone building abutting the fence, possibly at a gate. One of these outbuildings may represent a deadhouse or mortuary. The frame building outside the southwest corner of the fence is probably a double sink. No archeological evidence of the sink or outbuildings was found.

The 1874 map (see Figure 11) depicts both the Old and New Hospitals (the latter would have been constructed shortly before this map was made). The complex is shown as a two-room dispensary and storage building facing north and three separate stone buildings in a line behind it. To the east of the front building are two outbuildings, and a large outbuilding also occurs in the southeast corner of the yard. A sink outside the southwest corner of the yard is the only nonstone building depicted.

The 1875 map (see Figure 12) labels the Old Hospital as officers' quarters consisting of three stone buildings in a $\mathrm{T}$ plan and, to the southwest, a wooden sink. The 1876 map (see Figure 13) also labels the complex as officers' quarters and shows two sets of entrance steps on either end of the former dispensary and storeroom front porch.

An 1884 photograph shows a side-gabled frame hospital building moved from the Old Hospital complex to a nearby ranch in 1876 (Figure 42). Although none of the structures shown as frame construction on the ca. 1871, 1874, 1875, or 1876 maps appear to match the linear plan and full front porch of this photographed building reported to have been moved from the Old Hospital, its dimensions match the two-room dispensary and storage building at the front of the complex, which actually was of wood rather than stone construction. The windows, doors, and their hardware also appear to be those typical of military buildings at the fort. The photograph shows the ridgeline chimney and deep porch. The depth of the porch is indicated by the carriage parked underneath. The portion of the porch in front of the end room with fireplace is enclosed. This end room has a louvered wooden shutter and attic vent window, and sections of the board-and-batten siding are visible (Texas Parks and Wildlife Department 1975:205).

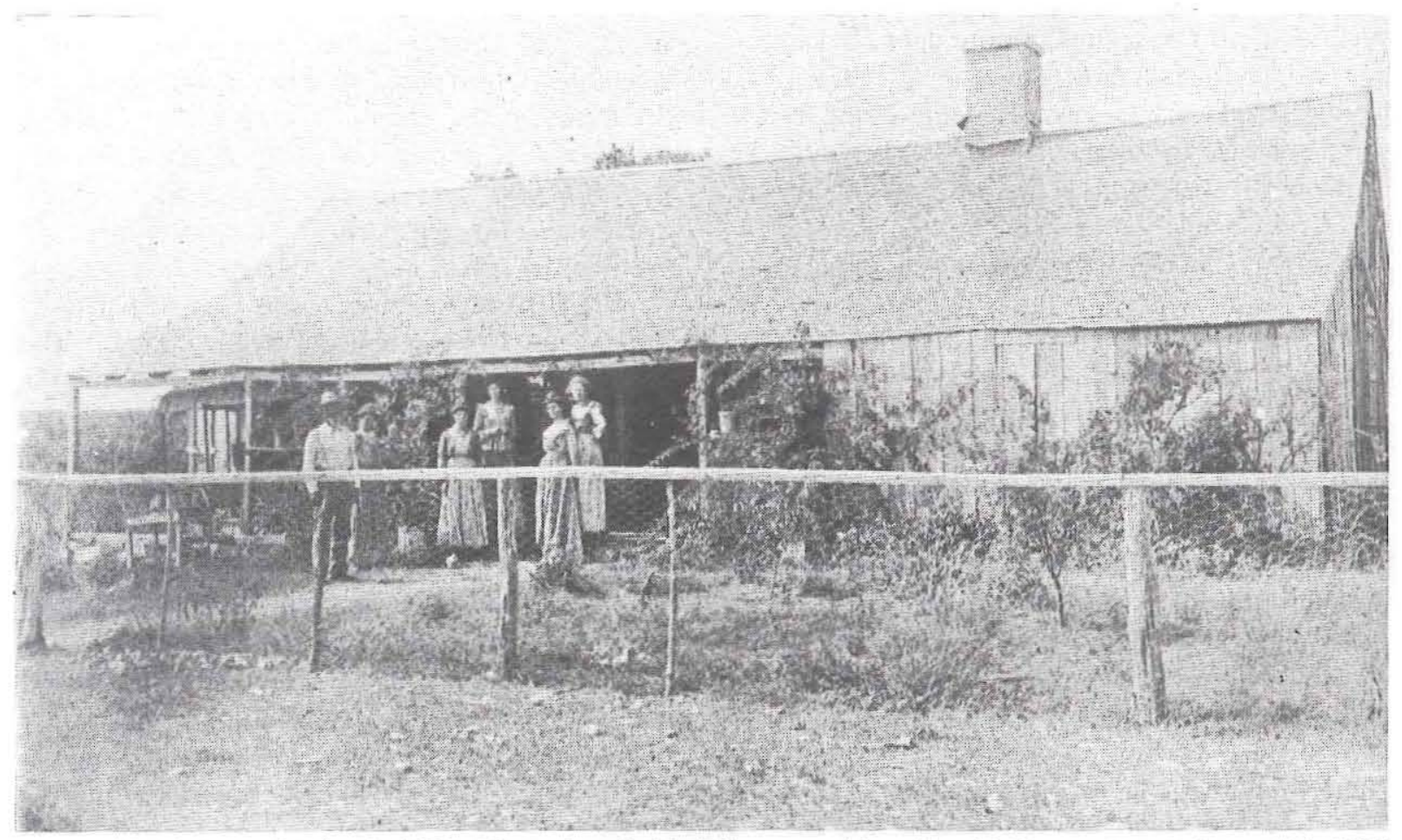

Figure 42. Photograph taken in 1884 of frame hospital building moved from Fort McKavett to a nearby ranch in 1876 (Texas Parks and Wildlife Department 1975:205). 
Another photograph from approximately the same time period, based on the enclosed porch, condition of the house, vegetation, and clothing, was taken from the other end of the house. This photograph indicates a single window and attic on the opposite gable end from the end room with fireplace and a window and door on the front of this same room. The windows visible in the photograph appear to be four-over-four lights.

Oral history is available for this frame building. Mr. and Mrs. Ed H. Grobe near Menard were interviewed by Dan Crouch of TPWD in November 1979 about the building formerly present near the Grobe residence. The building was referred to as the Fort McKavett Old Hospital and stood on land inherited by Mrs. Grobe from her mother; her grandparents also lived here, and her grandfather was the one who moved the building. At its new location, the wood building was placed on a stone foundation, the remains of which are in the parking area in front of the front yard fence of the presently occupied stone house built in 1940 .

The wooden building with cedar shingles stood at this location for many years and likely was used as a habitation by Mrs. Grobe's grandparents. The building was divided into two end rooms and a larger central room, with a partially enclosed deep front porch, a front door flanked by two windows, and three doors on the back. A double fireplace was shared by the central room and the room behind the enclosed porch. One side of the porch was enclosed and used as a bedroom. The back doorway was large enough for wagon access, and a wagon was parked for a long period in the central room when the building was used as a shed and carriage house.

Soon after the turn of the century, the family obtained a Sears mail-order house for use as a habitation, with the Old Hospital then used as a shed and carriage house. Soon after the stone house was built, both the frame Sears house and the Old Hospital building were dismantled and portions of each were used in building a sheet metal and board-and-batten shed in the same location. The shed contains full-cut wide lumber with circular saw marks and nail holes from prior attachment, and the presence of military-period doors, shuttered windows, and hardware indicates that some of the Old Hospital building's materials were retained in the construction of this shed.

A 1911 photograph of the 1874 stone hospital shows the ruins of the Old Hospital (Texas Parks and Wildlife Department 1975:206), but the standing building is obscured by vegetation and little description is possible. No chimney is evident in the ruins.

The Old Hospital complex was in ruins when TPWD acquired the fort property in 1975 . Collection of surface artifacts and excavation took place in 1978 and in the fall of 1979.

\section{Archeological Results}

A grid was established in a linear 150 -ft-long area in the Old Hospital complex. Vegetation was cleared and artifacts collected from this and adjacent areas, including a $20-\mathrm{x}-50$-ft-wide perpendicular extension (Figure 43). The grid encompassed part of the two-room stone dispensary and storeroom/officers' quarters building and extended to the south to include the area of the possible stone kitchen, the picket building, and the frame building. Rock foundations and stone distributions were mapped across this area as well. The mapped stone distributions include both military-period structures, such as the two-room structure with possible chimney base and the possible stone kitchen and latrine, and civilian-period features such as the circular feature and east-west alignments possibly relating to erosion control.

Units in the vicinity of the picket building were tested. Sediments were dry screened through $1 / 4$-inch mesh. Deposits were shovel skimmed and troweled. The portions of the picket building exposed by excavation measured $22 \times 12.5 \mathrm{ft}$ (interior). These figures differ from the historically reported measurements of $20 \times 18 \mathrm{ft}$. The picket trench was approximately $0.3 \mathrm{ft}$ below the surface and 1-1.5 ft wide and filled with mortar fragments, rocks, and tan to light brown sediment in a matrix of dark brown to brownish gray loam with rocks. An east-west rock alignment was perpendicular to the picket trench in S105-107/ W5-10. The top layer was loose dark brown sandy loam with abundant glass and nails. The second layer into which the picket trench was set was compact with blocky structure. The rocks included both stream-rounded bedrock and angular and broken shaped fragments. Artifacts from the northeast corner of the building included ceramics, bottle glass, a tin can fragment with mortar, and window glass. A concentration of cut nails was 


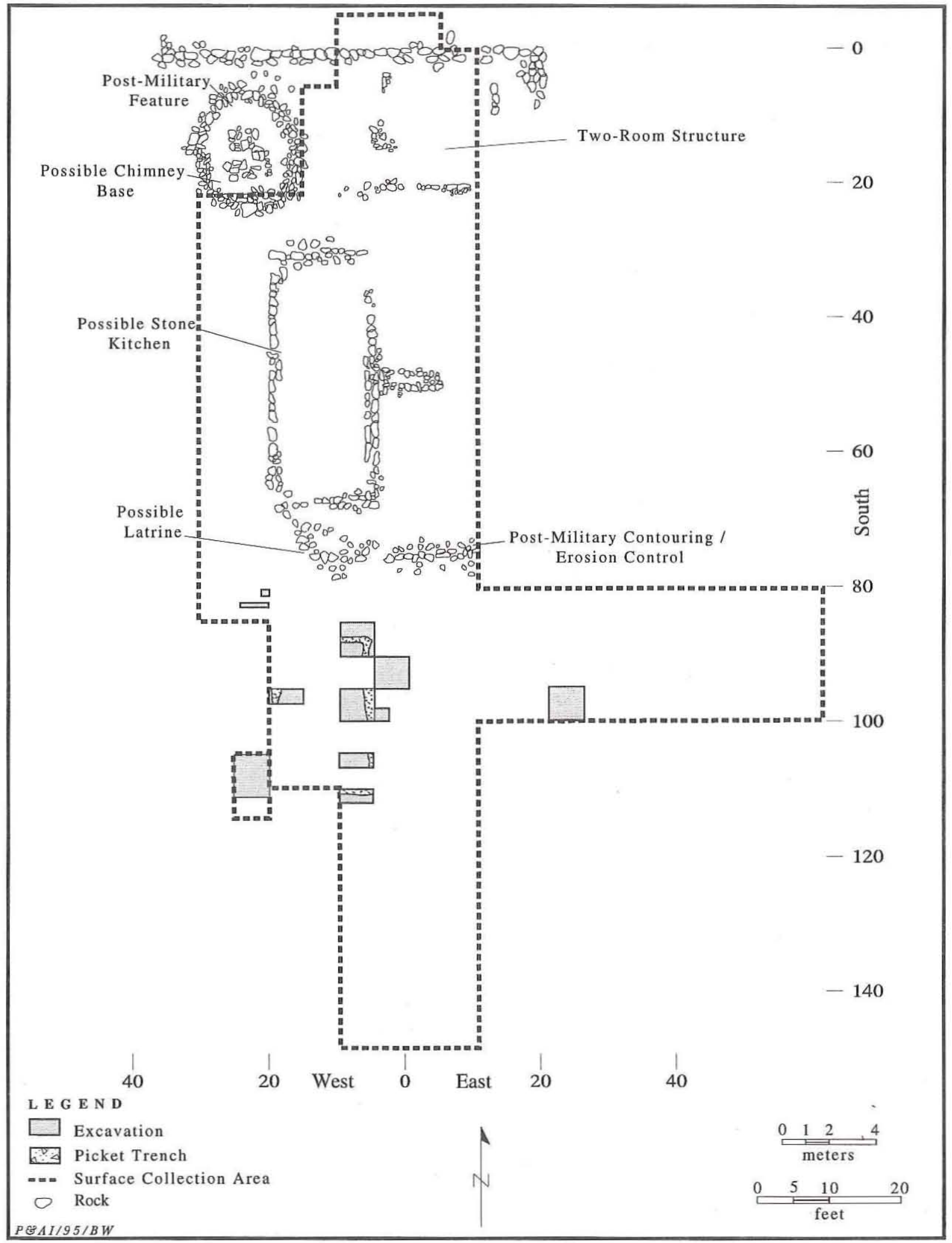

Figure 43. Plan of Old Hospital complex showing surface collection area and excavations. 
found to the north of the north wall. Artifacts from the south wall of the building included a colorless medicine bottle fragment and tin can and nail fragments. A drill bit was found in an ashy area in dark grayish brown clay loam above the northeast corner of the building in S85-90/W5-10.

A 1-x-3-ft unit was excavated in S82-83/ W20-23 in an ash lens and rock pile that was thought to be possibly the remains of an exterior fireplace at the northwest corner of the picket building. Numerous 6-inch-diameter rocks at $0.3-0.4 \mathrm{ft}$ deep were found. Dark brown humus overlay gray ash, which was densest in the eastern half of the unit and extended to $0.3 \mathrm{ft}$ deep. Artifact density was unusually high. Trash appears to have been thrown on a fire and rocks piled on the trash.

A 0.05-ft-thick layer of lime mud mortar similar to that used in stone wall construction at the site occurred in S105-110/W20-25 southwest of the picket building. This mortar had washed out from an adjoining large rock pile feature that was thought to represent the remains of a possible unexcavated exterior fireplace. The sediments below $0.5 \mathrm{ft}$ below the surface were undisturbed.

Excavation in S90-95/W0-5 east of the picket building encountered unconsolidated dark brown silty loam approximately $0.15 \mathrm{ft}$ thick over a dark grayish brown clay loam with limestone rocks scattered throughout and some embedded artifacts. Excavation in S95-100/E20-25 east of the picket building encountered a loosely consolidated dark brown humus containing whitewares, a groundglass stopper, bottle glass, cut nails, wire, and cast iron.

\section{SCHOOLHOUSE}

The schoolhouse is in the center of the south end of the fort, between the Old Hospital and Officers' Quarters 11 and behind Officers' Quarters 3 . The schoolhouse is a rectangular one-room building.

\section{History}

A ca. 1876-1883 building inventory listed the schoolhouse as one room measuring $25 \times 53 \mathrm{ft}$ (Bierschwale 1966:121). An August 4, 1875, letter to the Adjutant General of the Army stated that the construction of a stone building for a schoolhouse had been disapproved. On September 11, 1876, the commanding officer at Fort McKavett stated that the walls of the schoolhouse were almost complete, and the school was not reported as being officially established in the stone building until November 5, 1878. The fact that the schoolhouse is not pictured on the ca. $1871,1874,1875$, or 1876 maps of Fort McKavett (see Figures 10-13) supports the fort correspondence information that the building was completed between 1876 and 1878. Oral history reports that this building served as a school until the 1940s (Texas Parks and Wildlife Department 1975:211).

A pre-1912 photograph (C \& C photo \#35) shows the two end chimneys, the symmetrical door and window openings for cross-ventilation, and, unique for this view, the shed roof over the front porch (the presence of a south porch is uncertain), the enclosure of the doorless end of the porch, probably for a cloakroom or storage shed, and the school bell visible at the ridgeline of the roof. The double-hung windows have nine lights in each sash. The photograph shows stones in the front yard that may have been part of a walkway to the front door.

The 1912 photograph (see Figure 15) of Fort McKavett from the Commanding Officer's Quarters shows the east end of the schoolhouse. No front or back porch is present on the building by this time. Several people are present in the schoolhouse front (north) and side (east) yards.

A HABS photograph (Texas Parks and Wildlife Department 1975:213) and a probable HABS photograph without site number board (C \& C photo \#2) show the schoolhouse in 1936. The door and three windows are evenly spaced along the facade. By this time, the porch, including the enclosed room, and school bell had been removed. A shed room with a four-panel door is present on the west end of the building. No walkways leading to the south door appear to be present.

The schoolhouse was acquired by TPWD in 1968 and restored in 1971. The walls are constructed of coursed limestone rubble with roughsquared corners. The exterior is coated with whitewash. There are two doors, one on the north and one on the south, with dressed-stone entry steps. There are six windows, three on the north and three on the south. The hipped roof has wood shingles, and each end of the building has a roughsquared limestone chimney to vent wood-burning 
stoves. The interior has a board ceiling, plaster walls, and a pine floor over the original wood floor (Texas Parks and Wildlife Department 1975:211). Archeological excavation took place in the porch area on the north side of the building in the spring of 1985 and the fall of 1990 .

\section{Archeological Results}

Eight 4-x-4-ft units and 14 units varying in size from $1 \times 2 \mathrm{ft}$ to $1.5 \times 4 \mathrm{ft}$ were excavated in three tiers within $12 \mathrm{ft}$ from the north side of the building in search of porch stone foundations (Figure 44). A datum $10 \mathrm{ft}$ north of the center of this side of the building anchored this buildingspecific grid. Deposits above bedrock were very shallow.

Unit 2 near the northwest corner of the building contained a mortar lens in the northern half of the unit below the surface humus and root zone. This lens probably dates to the 1971 restoration of this building. In the southern half of the unit, the mortar lens sloped down 1-2 inches and was fragmented and mixed with rocks and sediment. Window glass from the adjacent westernmost window was abundant in loosely consolidated sandy sediment and occurred embedded in mortar in the eastern half of the unit. Below the mortar was very dark brown to black loam with frequent embedded glass and cut nails. Other artifacts include coal fragments, tacks, a hacksaw blade fragment, wire, glazier points, and a window latch fragment. Among the bedrock were glass fragments, cut nails, and wire recovered by fine screening. Additional excavation adjacent to the building exposed the original wall trench, which had only a cut nail associated with it.

In Unit 1 to the east, the dark topsoil with root zone overlay a hard smooth intermittent mortar surface consisting of a concentration and fragments of varying thickness covering the entire unit. Few artifacts were associated with this upper mortar stain. This mortar stain's location is not associated with either of the two westernmost windows or with the enclosed porch room shown in the pre-1912 photograph. The mortar apparently represents a remnant of the 1971 restoration. The mortar overlay a 0.1 -ft-thick dark surface containing modern artifacts such as wire nails and flat glass. The drip line associated with this mortar stain also indicates that the upper stain postdates the presence of the porch's shed roof. Below the modern surface was an additional mortar stain oriented north-south in black clay above bedrock and gravels. Small artifacts were associated with this stain. No apparent building construction debris was present in any of these deposits.

Unit 6 at the 0.32 -ft-wide north doorstep also contained a drip line depression extending $1.45 \mathrm{ft}$ north of the wall beneath the top organic layer. White mortar and sediment associated with the wall and black sediment associated with the step and drip line overlay a darker, gray sediment containing white-painted mortar in front of the step. Nails were scattered in front of the step. Below a thin lens of mortar-rich sediment in the center of the unit was a charcoal concentration with some ash. A charcoal lens also was present at the northeast corner of the unit. Bedrock occurred $0.1 \mathrm{ft}$ below the base of the white mortar layer. Against the wall, an attempt was made to distinguish the edge of the porch and later drip line 
area in the original ground surface by excavating within $1 \mathrm{ft}$ of the water table in $1 / 2$ - $\mathrm{ft}$ sections. Several large fragments of thick flat glass extending from $1-1.3 \mathrm{ft}$ north of the wall were lying flat as though resting on a surface at $0.15 \mathrm{ft}$ below the base of the white mortar layer.

Below the root zone in Unit 5 at the northeast corner of the building was gray loam with frequent recent mortar and whitewash from the 1971 restoration as well as wire nails, a modern beer bottle, and a ring tab from a modern can. Artifact frequencies were low in the mortar layer but increased in the brownish gray clayey loam below to include window and bottle glass and cut and wire nails. Excavated sediments between bedrock exposures were fine screened.

In Unit 4 at the northwest edge of the excavations, a 0.1 -ft-thick layer of compact grayish brown loam contained a ring tab opener from a modern can, two glass fragments, and a piece of chert. The grayer color and greater compaction of sediments in the southern half of the unit is probably attributable to mortar content from restoration. The second layer was less-compact grayish brown sediment above bedrock covering the entire unit. Artifacts occurred frequently in this layer and included bottle and window glass, cut nails, screws, and a screw-on top with a cork gasket.

In Unit 3 to the east of this unit, a brownish gray sediment contained a high density of artifacts, including glass, a .22 long rifle cartridge case, and straight pins. The dark brown sediment below contained a low density of artifacts above bedrock, primarily glass, and including half of a glass marble, a grommet, and a cotter pin head.

In Unit 7 in the outer tier of excavations beyond the northeast corner of the building, the layer below the topsoil was noncompact light gray sediment with glass and nails. Bedrock occurred at $0.4 \mathrm{ft}$ below the surface in brown clayey loam containing very few artifacts.

\section{MISCELLANEOUS STRUCTURES}

Limited surface artifact collection and excavation took place in four areas of the site, including collection from a shed in the vicinity of Barracks 3 , excavation in the vicinity of Barracks 6 , surface collection and limited excavation in the Farm to Market Road 864 reroute right-of-way in the vicinity of the sutler's store, and limited excava- tion in the vicinity of the lime kiln. Although a few artifacts resulted from this work, the collections either have tenuous associations with these structures or limited interpretive value.

\section{Barracks 3}

Surface artifact collection and excavation took place in the vicinity of Barracks 3 . This rectangular building was the fort's long barracks.

\section{History}

During the rebuilding program of 1868-1870, the ruins of the three separate barracks buildings on the north side of the main parade ground were combined to form a single barracks building $20 \times 324 \mathrm{ft}$ (Texas Parks and Wildlife Department 1975:229). The ca. 1871 map (see Figure 10) shows the barracks with a full front porch and, behind the barracks, one stone and one picket mess quarters in the first row and, in the second row, three stone sinks and one stone guardhouse with a stone cookhouse between the rows. The 1874 map (see Figure 11) depicts Barracks 3 as a nine-room structure with the westernmost room built of wood and a porch along the south side. Three kitchens, the easternmost one wood, were in the first row behind the barracks, and additional kitchens, laundresses' quarters, and sinks occurred behind these. The 1875 map (see Figure 12) shows a stone building with one wood room on the west end; a porch along the front; in the back, a first row of three stone kitchens and other outbuildings, some probably associated with adjacent barracks; and, on the second row, another stone kitchen and five pairs of wooden sinks with, in between the two rows, a stone laundresses' quarters building. The 1876 map (see Figure 13) shows this barracks divided into nine rooms with five sets of entrance steps on the front porch and, behind the barracks, a first row of three stone kitchens, a second row of one stone kitchen and five stone sinks, and two stone laundresses' quarters. The barracks was accessed by a walkway along the north side of the main parade ground and a north-south walkway through the center of the parade ground as well as walkways behind the barracks (the ca. 1871 map does not show the walkways behind the barracks).

This barracks was still standing in a 1911 photograph but was basically a ruin by 1920 . A 
very small section on the eastern end had some walls standing with lintels intact (Texas Parks and Wildlife Department 1975:230-231). Archeological work in two sinks and the west kitchen behind this barracks and collection from the shed standing in the vicinity took place in the spring of 1982 .

\section{Archeological Results}

Artifacts were removed from a standing shed in the vicinity of the east end of Barracks 3 . No excavation was involved. Artifacts collected include ceramics, glass, metal, lanterns, and leather and wood items that definitely were not in their original context.

The structure of two sinks behind the barracks, one adjacent to the gravel road and one farther west, was defined by clearing vegetation and sweeping the foundation. Partial foundations remained even though two houses had been removed from the vicinity. No documentation is available on this work. The stone floor of the west kitchen behind the barracks was cleared of vegetation and $\mathrm{a}<0.1-\mathrm{ft}$ layer of sediment. This building measured approximately $60 \mathrm{ft}$ north-south by $19 \mathrm{ft}$ east-west. Areas of the flagstone flooring and possibly most of the east end of the building were missing. One crosswall was present. Testing and documentation of this structure awaits further archeological work at the site.

\section{Barracks 6}

An area adjacent to and east of the original Farm to Market Road 864 route through the fort and north of Officers' Quarters 7-10 was excavated in search of structural remnants of Barracks 6 in the northeast corner of the secondary parade ground. This ca. five-room rectangular barracks also at one point was described as a mess and storehouse.

\section{History}

The ca. 1871 map shows a porch on the west side of the barracks (see Figure 10). This barracks is depicted on the 1874 map as a five-room structure, with four of those rooms of stone masonry and the south room of wood-frame construction (see Figure 11). The 1875 map shows no additional detail on this structure (see Figure 12). The
1876 map shows the barracks as a five-room stone structure (see Figure 13). The barracks is at the confluence of an east-west walkway through the secondary parade ground and the walkway along its east side as well as walkways from the laundresses' quarters to the east and, on all except the ca. 1871 map, a walkway from the post trader's store to the northeast. Informants said that this area was where the small twentieth-century Green Acres store used to stand. This frame store was moved to a location along Highway 29 about 50 years ago.

This barracks was a ruin when the fort property was acquired by TPWD. Excavation in the vicinity of this barracks took place in the spring of 1982.

\section{Archeological Results}

Vegetation was cleared from the area of a rock alignment near the road. The alignment was oriented $15^{\circ}$ east of north, only a few degrees different from parallel extant Barracks 4 , but it proved to be related to the store rather than to military construction. Nine $3-\mathrm{x}-2.5-\mathrm{ft}$ units were laid out on top of the approximately 2.5 -ft-wide alignment, and Units 1-6 were excavated. Sediments were screened.

Unit 1 produced small glass fragments and occasional bone fragments. Unit 4 consisted almost entirely of rocks. Metal artifacts, primarily crown caps, were frequent in Unit 5 below the roadbed in dark brown sediments. A layer of disintegrated mortar and whitewash and gray and red painted plaster fragments occurred in a military occupation zone approximately 0.5 inch thick. Unit 6 contained charcoal, window glass, small cement fragments, and a layer of crown caps. Most of the deposit, particularly the crown caps, appears to have resulted from disposal related to use of the building as a store, and little evidence of Barracks 6 remains.

\section{Farm to Market Road 864 Reroute Right-of-Way}

Surface collection and limited excavation took place in the Farm to Market Road 864 reroute right-of-way at the northeast corner of the fort east of the guardhouse. Military-era buildings reported to have existed in this area included the sutler's or 
post trader's store, a kitchen (Kitchen 5), and the chicken house.

\section{History}

The right-of-way is in the vicinity of the yard of the post trader's store on the 1874, 1875, and 1876 maps; the ca. 1871 map shows the "suttler's" [sic] store, kitchen, and chicken house and yard in this area (see Figures 10-13). There is no other information on these buildings (Texas Parks and Wildlife Department 1975:262).

\section{Archeological Results}

Twenty-four $10-\mathrm{x}-10$ - $\mathrm{ft}$ units in a 120 -ft northsouth by $40-\mathrm{ft}$ east-west grid north of the dirt road were surface collected in checkerboard fashion. A $5-\mathrm{x}-5$-ft unit (Unit 14) was placed in the southcentral part of the grid in the vicinity of a depression and rock scatter. A north-south alignment of four stones was found in the center of the unit. Artifacts include frequent bottle glass, whiteware and stoneware ceramics, tin cans, and cut and wire nails.

\section{Lime Kiln}

The 1850 s kiln downslope of the post-Civil War kiln has not been located, but ruins of two rectangular kilns are present in the southwest corner of the park (Texas Parks and Wildlife Department 1975:262). One unit was placed in the most accessible area of one of the kilns. The kiln was built into the side of a stream bank adjacent to the quarry. The base is broad and buried to provide support for the contents and to temper expansion during firing. An attempt was made to locate the floor of the firebox. The entrance to the firebox was cleared of stones, and the southwest corner was excavated. The original ground surface was marked by a charred log, and below this sediments contained little lime or ash. The kiln wall extended below this level for an unknown distance. The last firing appears to have been incomplete, with small stones powdery throughout and others powdery only on the surface.

\section{CONCLUSIONS}

Ten of the 16 structures investigated archeologically were officers' quarters. The pre-Civil War officers' quarters (Officers' Quarters 1-6) south of the parade ground originally were one-room kitchens that later were converted into officers' residences and, after the military abandoned the fort, into civilian residences. The four officers' quarters (Officers' Quarters 7-10) on the east side of the secondary parade ground were built as officers' residences originally and later were converted into civilian residences. The various ownership histories and, in particular, civilian uses of these buildings were the primary factors in the architectural modifications and the associated deposits that were recorded archeologically. The material evidence of the military occupations aside from the original construction proved to be limited in officers' quarters as well as other structures investigated. 


\section{ARTIFACTS}

\section{MILITARY ARTIFACTS}

The artifacts discussed in this chapter are military in function or date to the military period (see Chapter 3 for details). The approximately 200 military and 200 military-period artifacts represent a small sample of a very large, primarily civilianperiod, assemblage. As discussed in Chapter 3 and Appendix B, the artifact analysis done during this project focused on the military and military-era materials because the primary significance of the site derives from its role as a fort associated with early frontier defense.

\section{Arms and Ammunition}

\section{Firearms}

A steel pistol barrel from a Colt Model 1860 army revolver was found in the Officers' Quarters 5 shed. The barrel is round and 8 inches long. It is too corroded for a serial number, if present, to be legible. This arm was the principal revolver of the Civil War, with approximately 130,000 purchased by the U.S. government, and was made from about 1860 to 1873 (Traister 1989:80).

A steel trigger guard from Room 0 of Officers' Quarters 4 is from an unidentified pistol. The trigger guard is $2 \frac{3 / 4}{4}$ inches long and bent upward in the middle so that the shape is unknown.

\section{Artillery Shot}

A half-sphere of ferrous metal possibly represents an artillery shot fragment. The half-sphere is $3 \frac{3}{4}$ inches in diameter with a central hole $3 / 8$ inch wide all the way through. This size does not match the Civil War-era smoothbore and rifled field artillery weapon specifications in Peterson (1959), however, and the round hole does not appear to match the rectangular shape or large size of bars in dumbbell-shaped cannon bar shot, featuring half-spheres connected by bars and used to disrupt formations of men (Neumann and Kravic 1975:12).

\section{Percussion Caps}

A total of 39 percussion caps was recovered. The nine musket-sized percussion caps consist of five complete caps (including one fired), one crushed cap, and three fragments. The 29 pistolsized or ground-edge percussion caps consist of 4 complete, 1 crushed, and 24 fragments. One very small percussion cap fragment is of unknown size. The caps came in several sizes, and the nipples onto which they fit generally were correlated with pistol size, but an exact correlation between percussion cap type and a specific firearm is impossible (Herskovitz 1978:52).

\section{Conical Bullets and Shot}

Bullets and shot are discussed here under military artifacts, although some of these artifacts may date to the civilian period, so that the entire assemblage may be considered together. Conical bullets total 16 , and half of these are within the diameter range for .45-70-caliber cartridges (Table 2 ). The standard $.45-70$ rifle load was a threecannelure round-nosed 405-grain conical lead bullet with a cone-shaped base, increased in 1882 to a 500-grain bullet (Reuland 1991:7, 10). When 
TABLE 2

CONICAL BULLETS AND ROUND BALL AMMUNITION

\begin{tabular}{|c|c|c|c|}
\hline Diameter (inches) & Length (inches) & Type & Comments \\
\hline $\begin{array}{l}\text { Conical Bullets } \\
\text { fragment } \\
0.383 \\
0.401 \\
0.441 \\
0.447 \\
0.450 \\
0.451 \\
0.451 \\
0.457 \\
0.458 \\
0.459 \\
0.460 \\
0.524 \\
0.539 \\
0.573 \\
0.592\end{array}$ & $\begin{array}{l}\text { fragment } \\
0.603 \\
\text { fragment } \\
0.748 \\
0.779 \\
0.818 \\
1.110 \\
1.130 \\
0.749 \\
0.807 \\
0.603 \\
1.105 \\
1.064 \\
0.996 \\
1.064 \\
1.000\end{array}$ & $\begin{array}{l}? \\
.38 \text { caliber } \\
? \\
.44 \text { or } .45 \text { caliber } \\
.44 \text { or } .45 \text { caliber } \\
.45 \text { caliber } \\
.47-70 \text { caliber } \\
.45-70 \text { caliber } \\
.45 \text { caliber } \\
.45 \text { or } .46 \text { caliber } \\
.45 \text { caliber? } \\
.45-70 \text { caliber } \\
? \\
.54 \text { caliber } \\
.58 \text { caliber } \\
.58 \text { or } .60 \text { caliber? }\end{array}$ & $\begin{array}{l}162 \text { grain, fired and flattened } \\
128 \text { grain } \\
137 \text { grain, fired } \\
242 \text { grain } \\
245 \text { grain, heeled } \\
256 \text { grain, heeled } \\
427 \text { grain, } 3 \text { cannelures, unfired } \\
384 \text { grain, damaged } \\
250 \text { grain, } 2 \text { cannelures } \\
255 \text { grain, heeled } \\
187 \text { grain } \\
394 \text { grain, damaged } \\
457 \text { grain, solid base } \\
313 \text { grain, large hollow base } \\
488 \text { grain, } 3 \text { cannelures, extended base } \\
460 \text { grain, multiple small cannelures }\end{array}$ \\
\hline $\begin{array}{l}\text { Round Ball Ammunition } \\
0.324 \\
0.480 \\
0.480 \\
0.645 \\
0.646 \\
0.652 \\
0.655 \\
0.661\end{array}$ & $\begin{array}{l}- \\
- \\
- \\
- \\
- \\
- \\
-\end{array}$ & $\begin{array}{l}? \\
? \\
? \\
? \\
? \\
? \\
? \\
?\end{array}$ & $\begin{array}{l}48 \text { grain } \\
147 \text { grain } \\
159 \text { grain } \\
386 \text { grain } \\
404 \text { grain } \\
404 \text { grain, sprue mark } \\
412 \text { grain, sprue mark } \\
406 \text { grain, mold seam and sprue mark }\end{array}$ \\
\hline
\end{tabular}

the possible .45-caliber bullet weights are converted to grains by dividing by .0648 grain, one of the bullets (at 427 grains) falls within the rifle specifications; this is the only example that definitely had not been fired. The 384- and 394-grain examples also may be from rifle cartridges, as both are damaged and may have lost mass through firing. The 245-, 250-, 255-, and 256-grain examples match the 250-255-grain specifications for .45 Colt or .45 Smith \& Wesson pistol rounds (Logan 1959:139), respectively, and three of these examples are heeled. Heeling, or necking in the bullet at its base, was a technique occasionally used on .44- and .45-caliber bullets during the Civil War era. Three large-caliber and small-caliber bullets are not identifiable to caliber.

The round ball ammunition includes three large-caliber examples with sprue marks and, in one case, a mold seam. The other two largecaliber rounds probably also are from percussion ball rounds. The .324 -inch round may be from 0 Buck, from a multiball round, or from separately loaded ammunition, and the origin of the .480 -inch rounds also is unknown.

\section{Cartridge Cases}

Seventy-seven cartridge cases (46 military and 31 military period), including three complete cartridges, were analyzed. Eleven are rimfires (14 percent); .22-caliber cartridge cases were not analyzed since this caliber is too small for use as a military round and has been manufactured and used commonly for target practice and varmint shooting since its introduction in 1857. The remainder are centerfire cases ( 86 percent).

These archeological examples have experienced firing, metal corrosion in the ground, crushing, and breakage which have altered the dimensions out of true round and away from their origi- 
nal measurements after manufacture. Variability in cartridges made by different manufacturers and in cartridge case condition means that identifications often are not positive, and questionable identifications are indicated by question marks. Attributes observed are based on Barber (1987), Barnes (1989), Reuland (1991), and Waite and Ernst (1980).

\section{MILITARY CARTRIDGE CASES}

The 46 military cartridge cases have been classified using the following categories: rimfire $(\mathrm{n}=6)$, cup-primed .50-70 U.S. Government $(\mathrm{n}=6)$, externally primed $.50-70$ U.S. Government $(\mathrm{n}=1)$, cup-primed .45-70 U.S. Government $(\mathrm{n}=19)$, cup-primed $.45-70$ U.S. Government blanks $(n=4)$, and externally primed $.45-70$ U.S. Government $(n=10)$. Only three of the military cases have headstamps. Table 3 is grouped by types roughly corresponding to the chronological order of cartridge case introduction and by dimensions within each cartridge case type. Within the cup-primed category, early- and late-crimp .45-70caliber cases and ferrous- and nonferrous-cup .50caliber cases are distinguished. Military cartridge cases are one of the best indicators of the military occupation of the fort.

Rifle rimfire rounds are six .56-50-caliber Spencer cases, two of which have headstamps (see Table 3). The .56-50-caliber cartridge was designed by the Springfield Armory late in 1861 and was used in the 1865 model Spencer repeating carbine. This rifle and cartridge were issued to troops on the western frontier. The .56-50-caliber cartridge was listed in ammunition catalogs until approximately 1920 (Barnes 1989:368).

The .56-50-caliber rounds include two made by Fitch, Van Vechten \& Company from 1864 to 1865. The full range of this firm's production is unknown, but existing box labels or headstamped rounds indicate manufacture of all of the Spencer rimfire series (.56-46, .56-50, and .56-52 caliber).

The four unmarked rimfire cases include one without tool marks and three with different sets of tool marks. Fitch, Van Vechten \& Company used power head machinery that did not leave tool marks. The nearly aligned tool marks on one case (Figure $45 a$ ) are similar to the following published marks: the third example attributed to C. D. Leet and possibly the example attributed to Smith, Hall
\& Farmer and Smith, Hall \& Buckland and the first example attributed to Hall \& Hubbard (Barber 1987:186-187). These companies are possible manufacturers of this case. The tool mark on another case (Figure $45 b$ ) is somewhat similar to examples showing one tick mark near the rim, but this example is midway between the rim and the center and does not match any of the published examples. The third case (Figure 45c) has tick marks slightly out of alignment but in reverse order of the C. D. Leet tool marks on the first example above (Barber 1987:185-187).

The .50-70 U.S. government cartridge cases consist of six Benet- or cup-primed rifle rounds and one externally primed example. The Model 1865 Allin conversion rifle was further modified by reducing the barrel and chamber size to .50 caliber and making the cartridge centerfire. The standard load for the .50 -caliber cartridge was a 480 -grain conical lead bullet with a charge of 70 grains of black powder (Reuland 1991:4). The $.50-70$ was the United States military rifle cartridge from 1866 to 1873 . The first centerfire cartridge in general use by the military, the $.50-70$ U.S. government was derived from the .50-60-400 Joslyn rimfire and was used in various models of the single-shot Springfield rifle until replaced by the $.45-70$ in 1873 . This cartridge also was chambered in the Remington single-shot military rifle and in a large variety of single-shot and repeating sporting rifles and was popular through the 1870 s and $1880 \mathrm{~s}$ for big game. Very few rifles of this caliber are still in use, and the ammunition is almost nonexistent. Although no sporting rifles have chambered this round since the early 1900 s, Francis Bannerman \& Sons of New York City advertised both the $.50-70$ Springfield rifle and the ammunition, and rifles were available as late as 1940 (Barnes 1989:139).

Several different types of primers for the $.50-70$-caliber cartridge were tested and produced at the Frankford Arsenal. The original government cartridge had the inside cup primer. Thus, the cup-primed cases probably predate the one externally primed case recovered (Barnes 1989:139; Reuland 1991:4-6).

The .50-70-caliber cartridge cup primers were made in two forms - high and low cup. The high crimped cases have iron cups, and the low crimps have nonferrous cups, so that a magnet can be used to distinguish the two types (Reuland 1991:5). 
TABLE 3

MILITARY CARTRIDGE CASES

\begin{tabular}{|c|c|c|c|c|}
\hline Case (inches) & Rim (inches) & Length (inches) & Headstamp & Type \\
\hline \multicolumn{5}{|c|}{$.56-50$ Spencer, Rimfire } \\
\hline $\begin{aligned} & .626 \\
\simeq & .59 \\
\simeq & .59 \\
& .600 \\
\simeq & .59 \\
\simeq & .60\end{aligned}$ & $\begin{array}{l}.650 \\
.651 \\
.638 \\
.634 \\
.650 \\
.642\end{array}$ & $\begin{array}{l}1.160 \\
1.170 \\
1.180 \\
1.146 \\
1.158 \\
1.154\end{array}$ & $\begin{array}{l}\text { None } \\
\text { None } \\
\text { None } \\
\text { None } \\
\text { F.V.V \& Co. } \\
\text { F.V.V \& Co. }\end{array}$ & $\begin{array}{l}\text { tool marks (Barber 1987:181) } \\
\text { no tool marks (Barber 1987:181) } \\
\text { tool marks (Barber 1987:181) } \\
\text { tool marks } \\
\text { no tool marks (Barber 1987:181) } \\
\text { no tool marks (Barber 1987:181) }\end{array}$ \\
\hline \multicolumn{5}{|c|}{$.50-70$ U.S. Government, Cup Primed } \\
\hline $\begin{array}{l}.576 \\
.577 \\
.580 \\
- \\
.584 \\
-\end{array}$ & $\begin{array}{l}.665 \\
.672 \\
.655 \\
.662 \\
.660 \\
-\end{array}$ & $\begin{array}{l}1.569 \\
1.797 \\
1.761 \\
- \\
1.790 \\
-\end{array}$ & $\begin{array}{l}\text { None } \\
\text { None } \\
\text { None } \\
\text { None } \\
\text { None } \\
\text { None }\end{array}$ & $\begin{array}{l}\text { Ferrous cup, blank, never fired } \\
\text { Nonferrous cup } \\
\text { Nonferrous cup } \\
\text { Ferrous cup } \\
\text { Nonferrous cup } \\
\text { Nonferrous cup }\end{array}$ \\
\hline \multicolumn{5}{|c|}{$.50-70$ U.S. Government, Externally Primed } \\
\hline .584 & .660 & 1.772 & None & Berdan primer \\
\hline \multicolumn{5}{|c|}{$.45-70$ U.S. Government, Cup Primed } \\
\hline $\begin{array}{l}.500 \\
.501 \\
.501 \\
.502 \\
.508 \\
.509 \\
.510 \\
.510 \\
.515 \\
.515 \\
.515 \\
.517 \\
.518 \\
.519 \\
.520 \\
.520 \\
.529 \\
.530 \\
.551\end{array}$ & $\begin{array}{l}.607 \\
.601 \\
.611 \\
.605 \\
.610 \\
.605 \\
.610 \\
.610 \\
.600 \\
.604 \\
.611 \\
.606 \\
.607 \\
.610 \\
.608 \\
.610 \\
.606 \\
.601 \\
.614\end{array}$ & $\begin{array}{l}2.111 \\
2.095 \\
2.134 \\
2.094 \\
2.121 \\
2.110 \\
2.117 \\
2.127 \\
2.10 \\
2.077 \\
2.129 \\
2.115 \\
2.100 \\
2.126 \\
2.122 \\
2.110 \\
2.079 \\
2.099 \\
2.087\end{array}$ & $\begin{array}{l}\text { None } \\
\text { None } \\
\text { None } \\
\text { None } \\
\text { None } \\
\text { None } \\
\text { None } \\
\text { None } \\
\text { None } \\
\text { None } \\
\text { None } \\
\text { None } \\
\text { None } \\
\text { None } \\
\text { None } \\
\text { None } \\
\text { None } \\
\text { None } \\
\text { None }\end{array}$ & $\begin{array}{l}\text { Early crimp } \\
\text { Late crimp? } \\
\text { Early crimp } \\
\text { Early crimp } \\
\text { Early crimp } \\
\text { Early crimp } \\
\text { Early crimp } \\
\text { Early crimp } \\
\text { Early crimp } \\
\text { Early crimp } \\
\text { Early crimp } \\
\text { Early crimp } \\
\text { Early crimp } \\
\text { Early crimp } \\
\text { Early crimp } \\
\text { Early crimp } \\
\text { Early crimp } \\
\text { Crimp not measurable } \\
\text { Early crimp }\end{array}$ \\
\hline \multicolumn{5}{|c|}{$.45-70$ U.S. Government, Cup-primed Blanks } \\
\hline $\begin{array}{l}- \\
.510 \\
.515 \\
.515\end{array}$ & $\begin{array}{r}\simeq .58 \\
.604 \\
.602 \\
.610\end{array}$ & $\begin{array}{l}1.56 \\
1.571 \\
1.587 \\
1.618\end{array}$ & $\begin{array}{l}\text { None } \\
\text { None } \\
\text { None } \\
\text { None }\end{array}$ & $\begin{array}{l}\text { Late crimp } \\
\text { Late crimp } \\
\text { Early crimp } \\
\text { Late crimp }\end{array}$ \\
\hline
\end{tabular}




\begin{tabular}{|c|c|c|l|l|}
\hline \multicolumn{6}{|l|}{ Table 3, continued } \\
\hline Case (inches) & Rim (inches) & Length (inches) & Headstamp & Type \\
\hline \multicolumn{5}{|c|}{$.45-70$ U.S. Government, Externally Primed } \\
\hline$\simeq .50$ & - & - & None & Boxer primer \\
$\simeq .51$ & - & - & None & Boxer primer \\
.505 & .595 & 2.114 & None & Boxer primer \\
.508 & .600 & - & None & Boxer primer, variant \\
.513 & .605 & 2.116 & None & Boxer primer \\
.519 & .603 & - & None & Boxer primer \\
.522 & .610 & - & None & Boxer primer, variant \\
.538 & .592 & 2.046 & F 4 R 82 & Boxer primer \\
- & $\simeq .61$ & - & None & Boxer primer \\
- & $\simeq .59$ & $\simeq 2.1$ & None & Boxer primer \\
\hline
\end{tabular}

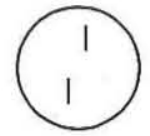

a

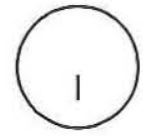

b

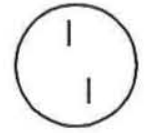

c
Figure 45. Tool marks on .56-50-caliber Spencer rimfire cartridge case heads.

Two of the internally primed examples have ferrous cups indicating a high crimp, and one of these is a blank. The blank has a tapered mouth and has a shorter case length (approximately .15 inch shorter) in this example than the standardissue cartridge. Blanks were made in .50-caliber cartridges into the mid 1880s (Reuland 1991:16).

The one externally primed $.50-70$-caliber case has a Berdan primer. Civilian manufacturers used different types of external primers. Berdan primers, which became popular in England and Europe, were used by the Union Metallic Cartridge Company (Reuland 1991:6).

Thirty-three $.45-70$ U.S. government cases were recovered. The 2.1-inch-long .45-70 U.S. government cartridge case containing a 405 -grain conical lead bullet and 55 grains (carbine load) or 70 grains (rifle load) of black powder was adopted in 1873 to be used with the Allin conversion or trapdoor Springfield rifle. The rifle and carbine cartridges had the same case lengths (Reuland 1991:2, 7-8).

The standard-issue cartridge was inside cup or Benet primed, with two crimps on the side of the case holding the primer cup in place. Cup-primed cases were not reloadable. The Frankford Arsenal outside of Philadelphia, Pennsylvania, was the ammunition production center for the United States government. In January of 1874 the arsenal began mass production of .45 -caliber ammunition for the Springfield trapdoor rifles and carbines. With the exception of carbine cartridges made from March to July of 1874, Frankford Arsenal cartridges predating March 1877 were not headstamped. Many versions of this standard cartridge came into production after the military's adoption of the .45caliber cartridge, and both government and private contractors produced large quantities of this caliber cartridge (Reuland 1991:2, 8-9).

Twenty-three cup-primed .45-70 U.S. government cartridge cases were recovered from the fort, including four blanks. Blanks were filled with 70 grains of black powder and shellac after compressing, and the cases have tapered mouths. The examples from the fort are 0.5 inch shorter than typical . 45-70 cases and do not appear to be tapered. Blanks were used for ceremonial purposes, such as funerals and salutes, or for training horses (Reuland 1991:16).

The head of the early cartridges had a propensity to tear upon extraction, and the Frankford Arsenal soon increased the thickness of the case above the head. The space between the crimp ends on the early cup-primed cartridges, including those made from March to July of 1874 and perhaps also including those made before widespread headstamping in March 1877, was wider than on later cup-primed cartridges (Figure 46). Reports of the cup being dislodged during firing may have been a reason for extending the crimp length. The cup- 


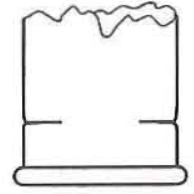

a

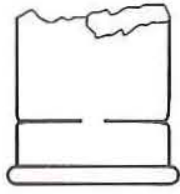

b
Figure 46. Cup-primed cartridge cases with (a) early and $(b)$ late crimps.

primed case was produced until August 1882, when it was replaced by a solid-head Boxer-primed cartridge (Reuland 1991:9-10).

Only one of the 19 cup-primed .45-70 standard-issue cartridge cases has a possible late crimp opening of approximately $1 / 8$ inch (one other example was too corroded to observe crimp distance); all others have the approximately $1 / 4$-inch early crimp opening, indicating manufacture in the mid 1870s. Three of four blanks, however, have late crimps, indicating manufacture from the late $1870 \mathrm{~s}$ until 1882.

Even after the .30-40 Krag was adopted by the military in 1892, the Frankford Arsenal continued manufacturing externally primed .45-70-caliber ammunition for the regular army until 1895 and for the navy and militias until 1898 (Reuland 1991:16). Many modern-day rifles and some handguns chamber the $.45-70$ cartridge. Most state militias and some volunteer regiments mobilized for the Spanish-American War were equipped with the $.45-70$, and many state militias used this rifle well into the twentieth century. Sporting rifles of this caliber were discontinued temporarily in the 1930 s, but the cartridge has returned to popularity in recent times.

The only headstamped $.45-70$ cartridge case is from a rifle round with a Boxer primer along with marks indicating production by the Frankford Arsenal in April 1882, four months before the date of authorized replacement of cup primers by external primers. An externally primed solid-head cartridge with 70-grain powder charge and 500grain bullet was first made in 1879 , however, and in 1881 a similar round was adopted for reloading purposes. In 1882, this round became standard for use in the service rifle (Waite and Ernst 1980:168).

The nine unmarked externally primed cases have Boxer primers. The Boxer-primed cases probably had a longer use-life than Berdan-primed cases. The first .45 -caliber rifle cartridges pur- chased from the Union Metallic Cartridge Company had Berdan primers which, after firing, had to be pried out of their pockets with a special tool, while Winchester and United States Cartridge Company cases with Boxer primers could be decapped quickly and easily with a punch inserted through the case mouth. The Union Metallic Cartridge Company eventually introduced a solidhead-case Boxer-type primer that could be decapped with a punch (Waite and Ernst 1980:165-167). Two of the unmarked cases are variants of the standard Boxer primer with reinforced heads and flash holes.

\section{MILITARY-PERIOD CARTRIDGE CASES}

Cartridges, cartridge cases, and shotshells were assigned to the military period based on the combined date of the cartridge and its headstamp, when present. Cases with date ranges extending into the civilian period (the fort was abandoned in 1883) are included in the military period. Unmarked cases also were assigned to the military period since many nineteenth-century military cartridges were unmarked. As a result, all examples listed under the military period are not necessarily military cartridge cases, although they may have been used by soldiers. Cartridge cases assigned to the military period number 31 , and 18 of these have impressed headstamps, none of which are raised.

Handgun or rifle rimfire cases consist of three .32 Long or .320 Long and two .41 Short or .410 rounds, listed in Table 4, which is organized by cartridge type and headstamps. Hundreds of thousands of rimfire handguns were produced after the 1869 expiration of the Rollin White patent (Barber 1987).

The .32 Long cartridge originally was a revolver caliber, introduced for the Smith \& Wesson New Model \#2 revolver in 1861, but it was used extensively in various rifles. The round was good at short range for killing small game because it did so without mangling or -ruining edible meat. It was listed in twentieth-century catalogs but is no longer produced in the United States. Single-shot Stevens rifles of this caliber were made as late as 1936 (Barber 1987:179; Barnes 1989:364).

The .41 Short is an old rimfire cartridge, once very popular due to the inexpensive pocket hand- 
TABLE 4

MILITARY-PERIOD CARTRIDGE CASES

\begin{tabular}{|c|c|c|c|c|}
\hline $\begin{array}{l}\text { Case } \\
\text { (inches) }\end{array}$ & $\begin{array}{l}\text { Rim } \\
\text { (inches) }\end{array}$ & $\begin{array}{l}\text { Length } \\
\text { (inches) }\end{array}$ & Headstamp & Type \\
\hline \multicolumn{5}{|c|}{ Rimfire } \\
\hline $\begin{array}{l}.330 \\
.330 \\
.340 \\
.408 \\
.420\end{array}$ & $\begin{array}{l}.375 \\
.385 \\
.385 \\
.469 \\
.475\end{array}$ & $\begin{array}{l}.798 \\
.801 \\
.795 \\
.479 \\
.475\end{array}$ & $\begin{array}{l}\text { None } \\
\text { None } \\
\text { None } \\
\text { None } \\
\text { None }\end{array}$ & $\begin{array}{l}.32 \text { Long or .320 Long? (B } \\
.32 \text { Long? (Barber 1987:17 } \\
.32 \text { Long? (Barber 1987:17 } \\
.41 \text { Short (Barber 1987:180 } \\
.41 \text { Short or } .410 \text { ? (Barber }\end{array}$ \\
\hline \multicolumn{5}{|c|}{ Centerfire, Headstamped } \\
\hline $\begin{array}{c}.341 \\
\simeq .366 \\
- \\
.390 \\
.392 \\
.509 \\
.480 \\
- \\
.475 \\
- \\
.508 \\
\simeq .46 \\
.451 \\
.487 \\
- \\
.50\end{array}$ & $\begin{array}{l}.384 \\
.407 \\
.408 \\
.435 \\
.430 \\
.527 \\
.520 \\
.524 \\
.518 \\
.510 \\
.533 \\
.518 \\
.503 \\
.509 \\
.512 \\
-\end{array}$ & $\begin{array}{l}- \\
1.313 \\
- \\
.754 \\
.761 \\
1.300 \\
1.284 \\
- \\
- \\
- \\
1.326 \\
- \\
1.285 \\
1.243 \\
- \\
-\end{array}$ & $\begin{array}{l}\text { U.M.C./32 S \& W } \\
\text { W R A CO/.32 W C F } \\
\ldots . / 32 \text { WCF } \\
\text { W.R.A. CO./38 S.W } \\
\text { U M C/38 S \& W } \\
\text { UMC/38 WCF } \\
\text { W R A CO/44 W.C.F. } \\
\text { W R A CO/44 W C F } \\
\text { WRA CO./44 } 4 \text { WCF } \\
\text { U M C/ } 44 \text { CFW } \\
\text { U M C/44 C.F.W } \\
\text { U.M.C./440 L.M.R. } \\
\text { WRA CO/45 COLT } \\
\ldots . \text { CO/45 COLT } \\
\text { U.M.C. } / 45 \text { COLT } \\
\text { U M C } / . .\end{array}$ & $\begin{array}{l}.32 \text { Smith \& Wesson } \\
.32 \text { or } .32-20 \text { Winchester } \\
.32 \text { or } .32-20 \text { Winchester } \\
.38 \text { Smith \& Wesson } \\
.38 \text { Smith \& Wesson } \\
.38-40 \text { Winchester } \\
.44-40 \text { Winchester } \\
.44-40 \text { Winchester } \\
.44-40 \text { Winchester } \\
.44-40 \text { Winchester } \\
.44-40 \text { Winchester } \\
\text { Boxer primer centerfire } \\
.45 \text { Colt } \\
.45 \text { Colt } \\
.45 \text { Colt } \\
\text { External primer }\end{array}$ \\
\hline
\end{tabular}

Externally Primed Centerfire, Unmarked

\begin{tabular}{|c|c|c|c|c|}
\hline $\begin{array}{l}.418 \\
.444 \\
.455 \\
- \\
- \\
- \\
-\end{array}$ & $\begin{aligned} & .448 \\
& .514 \\
& .490 \\
& \simeq .50 \\
& .518 \\
& .520 \\
& .520\end{aligned}$ & $\begin{array}{l}.768 \\
- \\
.859 \\
- \\
- \\
- \\
-\end{array}$ & $\begin{array}{l}\text { None } \\
\text { None } \\
\text { None } \\
\text { None } \\
\text { None } \\
\text { None } \\
\text { None }\end{array}$ & $\begin{array}{l}- \\
- \\
\simeq 44 \text { caliber } \\
- \\
- \\
- \\
-\end{array}$ \\
\hline \multicolumn{5}{|c|}{ Shotshells } \\
\hline $\begin{array}{l}.815 \\
.856 \\
.719\end{array}$ & $\begin{array}{l}.871 \\
.883 \\
.750\end{array}$ & $\begin{array}{l}2.576 \\
- \\
2.541\end{array}$ & $\begin{array}{l}\text { U M C CO } \\
\text { BRIDGEPORT CONN/12 } \\
\text { Illegible } \\
\text { None }\end{array}$ & $\begin{array}{l}12 \text { gauge, brass } \\
\simeq 12 \text { gauge, brass } \\
\simeq 20 \text { gauge, brass }\end{array}$ \\
\hline
\end{tabular}

guns, particularly the Remington over/under or double derringer, manufactured from 1866 to 1935 , that chambered it. The cartridge was introduced with the National Arms Co. breechloading derringer in 1863 or 1864 and has been obsolete since World War II, but special lots of ammunition have been loaded since the war (Barber 1987:180; Barnes 1989:366).

The seven unmarked centerfire military-period cases include five cases with incomplete measurements that are not discussed further. Two unmarked examples do not match the specifications 
in Barnes $(1989: 146-147,256)$ for obsolete American rifle and pistol and revolver cartridges; one of these is approximately .44 caliber. A large-caliber externally primed case made by Union Metallic Cartridge Company from 1867 to 1911 (Barber $1987: 38,48)$ also is unidentified as to caliber. The dates of 1867 to 1911 are used in this report for the Union Metallic Cartridge Company before its merger with the Remington Arms Company in 1911. There is no information that Hartley \& Graham's (owners of Union Metallic Cartridge Company) and Winchester Repeating Arms Company's joint purchase of E. Remington \& Sons in 1888 and the subsequent sale in 1896 by Winchester of its share in Remington Arms Company to Hartley \& Graham (Barber 1987:36, 48) resulted in changes in cartridge headstamps until 1911.

A .32 Smith \& Wesson cartridge case was made by the Union Metallic Cartridge Company. The cartridge was introduced in 1878 for the Smith \& Wesson Model 1 1 $1 \frac{2}{2}$ hinged-frame, single-action revolver. This is a very popular cartridge, widely used in the United States and Europe for lowpriced pocket revolvers (Barnes 1989:226, 255).

Two cartridge cases are marked .32 Winchester, and at least one of these was made by the Winchester Repeating Arms Company, in business from 1867 to 1938 . Although designed primarily as a rifle cartridge, the .32 Winchester or .32-20 was popular as a handgun cartridge, also. The .32-20 was introduced by Winchester in 1882 for their Model 1873 lever-action rifle and quickly attained considerable popularity as a mediumpower cartridge in both rifle and revolver. Practically all American makers have chambered rifles for the .32-20 cartridge, and Colt, Smith \& Wesson, and Bayard made revolvers in this caliber (Barber 1987:11, 87-88; Barnes 1989:67, 228).

One .38 Smith $\&$ Wesson case was made by the Winchester Repeating Arms Company from 1877 to 1938 and another by the Union Metallic Cartridge Company from 1877 to 1911 (Barber 1987:11, 87-88; Barnes 1989:255). This cartridge was designed for the Smith \& Wesson hingedframe revolver introduced about 1877 and has been used widely all over the world, particularly in the United States and also in Great Britain, the British Commonwealth, and Hispanic America. The cartridge is well suited to lightweight pocket handguns (Barnes 1989:239).
A . 38-40 Winchester cartridge case was made by the Union Metallic Cartridge Company from 1874 until 1911. The .38-40 cartridge was developed by Winchester as a necked-down .40-caliber companion cartridge to their popular .44-40. The .38-40 was introduced in 1874 for the Winchester Model 73 lever-action rifle and was a fairly popular medium-power cartridge until about 1920, after which it declined in sales. No rifles have been chambered for the .38-40 since about 1937 . Designed primarily as a lever-action and singleshot rifle cartridge, the $.38-40$ was a popular handgun cartridge also (Barber 1987:38, 48; Barnes 1989:86, 241).

Three of the five .44-40 Winchester cases were made by the Winchester Repeating Arms Company, and two were made by the Union Metallic Cartridge Company. The Winchester Repeating Arms Company made this cartridge from 1873 to 1938 , and the Union Metallic Cartridge Company from 1873 to 1911 (Barber 1987:11, 38, 48, 87-88; Barnes 1989:96; Traister 1989:248). The .44-40 Winchester was the original cartridge for the famous Winchester Model 1873 lever-action repeating rifle. The $.44-40$ is said to have killed more game and more people than any other commercial cartridge ever developed. In its original black-powder loading, it was the first effective combination cartridge that could be used interchangeably in rifle or revolver, and it was a great favorite in the early days of the American West. Most American arms manufacturers have offered a firearm chambered for this cartridge, and most of the single-shot rifles made in the United States included a .44-40 model. The cartridge was made obsolete in the revolver by the .357 and .44 Magnums and in the rifle by the $.30-30$ and similar cartridges with a flatter trajectory at ranges beyond 100 yards. No American-made rifles have chambered the round since 1937, but Colt revolvers retained it until about 1942 (Barnes 1989:89). However, ammunition may be available long after the corresponding weapons are no longer made.

The .440 L.M.R. case is unidentified as to type but was made by the Union Metallic Cartridge Company, which was in business from 1867 to 1911 (Barber 1987:38, 48).

The three .45 Colt cases are headstamped, and two of these have identifiable manufacturers. The U.M.C. case was made by Union Metallic Cartridge Company from 1873 to 1911 (Barber 1987: 
38, 48), and the W.R.A. case by Winchester Repeating Arms Company from 1873 to 1938 (Barber 1987:11, 87-88). The cartridge was introduced by Colt in 1873 as one of the cartridges for their famous "Peacemaker" single-action revolver. Both the cartridge and the revolver were adopted quickly by the U.S. Army and were not replaced until 1892. This was one of the most famous American handgun cartridges and is still a favorite with big-bore advocates for its accuracy, stopping power, and history (Barnes 1989:250, 256).

The three brass shotshells include one with a legible headstamp by the Union Metallic Cartridge Company, which was in business from 1867 to 1911 (Barber 1987:38, 48). This shotshell has a Boxer primer. The primer type on the other two examples is not visible because of corrosion. Many brass shotshells were sold as primed empties, with many made prior to 1900 but quite a few still in production as late as 1912 . Winchester Repeating Arms Company, for example, still advertised brass shells in its ca. 1908 catalog (Vinson 1968: 91). The Union Metallic Cartridge Company commonly used Berdan primers in its early years of production, as indicated in the 1871 U.M.C. catalog for 10- and 12-gauge shells (Vinson 1968:96) and in the use of these primers on .50-70-caliber cartridges that were military issue until 1873. The replacement of cup primers by Boxer primers on .45-70-caliber cartridges in 1882 (Reuland 1991:10) was part of a trend away from Berdan primers in the 1880s. The Boxer primer on a U.M.C. Company shotshell probably indicates an 1880 s to turn-of-the-century date, and the other two shotshells probably also predate World War I.

\section{Clothing and Insignia}

\section{Epaulets or Shoulder Scaleboards}

Portions of at least three detachable brass epaulets or shoulder scaleboards were found in Rooms 0 and 3 of Officers' Quarters 4, Officers' Quarters 6 and 8, Barracks 3, and the highway right-of-way. These consist of one scaleboard neck portion, three scales, and three strap slides. The scaleboard end (Figure 47) is rounded and the sides bound, the opening is $\mathrm{T}$ shaped, and the scaleboard and scales are approximately $2 \frac{1}{8}$ inches wide, indicating that these are from either the 1854

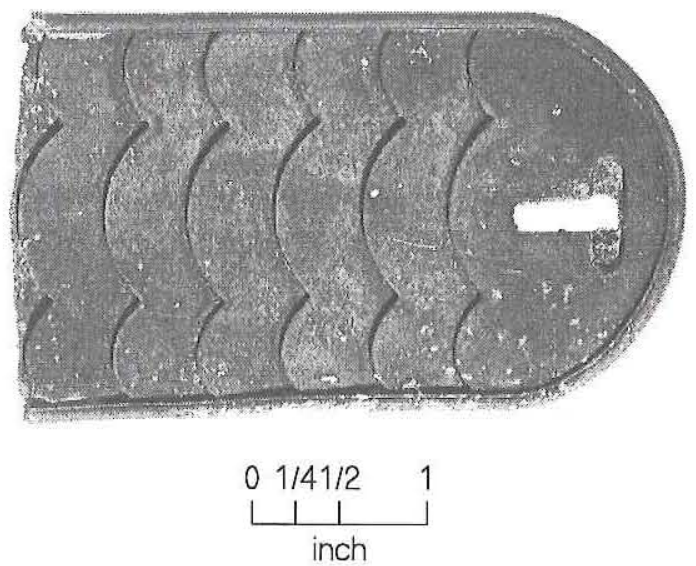

Figure 47. Shoulder scaleboard, neck portion.

pattern or mid-1850s sergeant type (Brinckerhoff 1976:33). A similar example for privates with the T-shaped opening is pictured in an 1864 military goods catalog (Schuyler, Hartley \& Graham $1864: 70$, No. 155). Since the crescent or oval is missing, positive identification cannot be made.

Shoulder scaleboards were issued to enlisted personnel of all branches for field and dress wear beginning in 1854. For example, in 1857 they were worn on the full-dress coat for infantry soldiers. From about 1862 until they were abolished in 1872, they normally were worn only for dress occasions and usually not at all. They were made in three patterns, one for privates and corporals, another with larger crescents or ovals for sergeants, and a third with round-headed rivets on the scallops for regimental and general staff noncommissioned officers. Serving no practical function, they were heartily disliked by the soldiers, who had to keep them polished to a high luster. The scales were attached to the uniform by thin brass strap slides on the undersides; the slides passed through flat brass staples sewn above each shoulder seam. The end of the strap next to the neck was held down by a small turnkey stitched to the coat (Brinckerhoff 1976:31-34; McChristian 1995:10, 12).

\section{Insignia}

Six fragments of brass insignia were found in Officers' Quarters 6 (two fragments), Barracks 2 (three fragments), and the Old Hospital (one fragment). These consist of fragments of two infantry horns, a fragment of a cavalry saber, one large company letter, and two small regimental numbers. 
Branch insignia ordinarily were worn on hats or caps. Insignia preserved in archeological sites usually are brass insignia worn by enlisted men. The thin brass insignia were attached by means of brass wire loops soldered to the back. Officers usually wore gold insignia embroidered on cloth, although occasionally they wore white metal regimental numbers or brass insignia with an embroidery pattern cast in the metal. Before 1858, all enlisted men of all branches wore only the brass 1-inch-high company letter on their hats. The $5 / 8$-inch-high regimental number was added in 1858 but did not replace the 1-inch-high numbers. The small brass company letters and regimental numbers were issued separately and measured $1 / 2$ inch high beginning in 1875 (Brinckerhoff 1976:7, 9, 11; McChristian 1995:14). Horstmann Bros. \& Co.'s 1877 military catalog (reprinted in 1972) lists all three sizes of letters and numbers available at that time, indicating considerable overlap in use of these insignia. The $5 / 8$-inch-high regimental number " 1 " indicates an 1858 or later date. Regiments at the fort with a " 1 " in their designation were the 1st Infantry, 41st Infantry, 10th Infantry, 10th Cavalry, and 16th Infantry. The 1/2inch-high regimental number " 6 " or " 9 " indicates an 1875 or later date; this number is possibly from a soldier in the 16th Infantry, at Fort McKavett from March 7, 1881, to August 21, 1882 (Texas Parks and Wildlife Department 1969:44). The 1inch-high Company "I" fragment indicates a pre1858 or later date.

There was little consistency in the manner of wearing the insignia on the forage cap. Some units wore only the company letter on the front of the cap, as per regulations, although this often proved impractical because the crowns of many of the contract caps fell so far forward that the letter could not be seen. Photographs indicate that many soldiers wore the branch insignia atop the crown and that others displayed the branch device along with letter and number. Still others used no insignia at all. It was not until 1875 that the army specified with the new crossed rifles insignia for infantry that the company letter was to be worn in the upper angle and the regimental number below. In reaction to inconsistency in placement for different branches of service, in 1877 the army issued an order that all line personnel were to wear the number in the upper angle of the branch device and the letter in the lower (McChristian 1995:16, 148).
In 1858 , a new horn device was issued for infantry field use with the Jeff Davis hat, with which the large 1 -inch company letter and $5 / 8$-inch regimental number were worn. This stamped brass bugle or "looped hunting horn" $13 \frac{3}{4}$ inches high and 3 inches wide was inspired by the French votigeurs and worn until 1875 , with the regimental number frequently placed within the bend and with the company letter above. A smaller version of the brass horn was issued during and after the Civil War for wear on the forage or "bummer" cap and was worn on the infantry dress shako during the 1872-1881 period. An example measuring 13/4 inches high and $3 \frac{1}{2}$ inches wide indicates an 1858-1875 date (Figure 48), and an identical-sized mouthpiece fragment from another example also dates to 1858-1875 since the smaller horn has a proportionally smaller mouthpiece and slightly different stylistic details. The horn was replaced by crossed .45-70-caliber rifle insignia for infantry beginning in 1875 (Brinckerhoff 1976:9-11; McChristian 1995:14). Six infantry regiments were present at Fort McKavett between 1858 and 1875 (Texas Parks and Wildlife Department 1969:44).

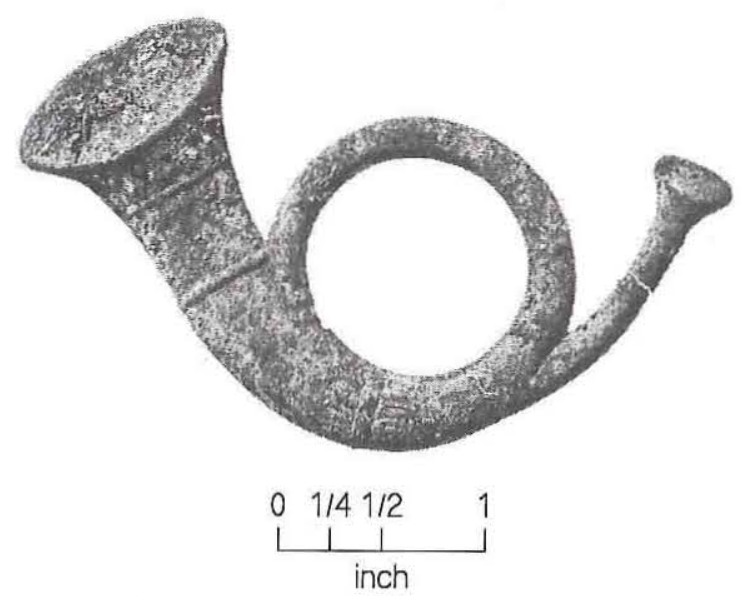

Figure 48. Large infantry bugle or hunting horn insignia.

In 1872 , the infantry horn insignia and the crossed sabers cavalry insignia were reduced in size by about half to a bugle 2 inches wide and crossed sabers $2 \frac{3}{4}$ inches wide. The new designs were more refined than the 1851 insignia. In November 1875 , crossed rifles replaced the bugle as the infantry's insignia; exempt from the order were the field and band musicians, who retained the bugle and wore the regimental number in the 
center and the company letter above (Brinckerhoff 1976:9; McChristian 1995:54-55, 147).

Crossed sabers were worn by dragoons beginning in 1851 and later by cavalrymen. The insignia were worn on the Jeff Davis hat and the kepi (forage cap). The large sabers measured $13 / 4$ inches high by $3^{1 / 4}$ inches wide and generally were not worn after about 1880 . The small sabers measured $1 \frac{1}{4}$ inches high by $23 / 4$ inches wide and were worn beginning in 1876 . In the 1870 s, a slightly smaller version was produced for the forage cap. The sabers were displayed with edges down from the late 1850 s until 1861 , when they were worn with edges up (Brinckerhoff 1976:7, 13). An incomplete example consists of the lower left half of a large saber insignia dating 1861 to 1880 . Cavalry regiments stationed at Fort McKavett during this period were the 4th, 9th, and 10th Cavalries (Texas Parks and Wildlife Department 1969:44).

\section{Identity Tag}

An identity tag (Figure 49) inscribed with a soldier's name was found in the Old Hospital. This shield-shaped plated ferrous metal medallion is $15 / 16$ inch high and $7 / 8$ inch wide with a small hole at the top for attachment to a chain. The identity tag is impressed "DELAWARE/PINN/CO. I/9th U.S. Cav." Some of the words, particularly "Delaware" and "U.S. Cav.," are not on a straight line. Civil War-era identity tags available commercially included styles with an eagle or shield on the obverse and the soldier's name, regiment, and company machine stamped on the reverse (Lord 1982:132). The blank for this identity tag was advertised as a German silver key check, used to identify hotel keys, in a Peck \& Snyder 1886 (reprinted 1971:n.p., No. 73) games and sporting goods catalog from New York. (A fancier, inscribed, silver-plated brass identity tag from the pre-1978 excavations at Fort McKavett [Black and Ing 1980:Figure 72c-d] was listed in this catalog). It seems likely that soldiers either ordered these key checks with name, regiment, and company imprinted for 25 cents each or that they ordered blanks and did their own imprinting.

Pinn's military records indicate he was never stationed at the fort, so he apparently lost the identity tag while he was in transit. He was sent to a post on the Rio Grande in response to an eye ailment, and he may have stayed at the hospital en

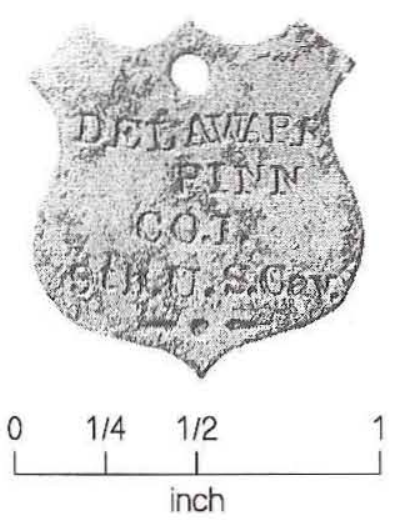

Figure 49. Identity tag.

route (Art Black, personal communication 1995).

\section{Buttons}

Buttons were abundant on nineteenth-century military clothing. Officers' buttons were gilt finished, bearing the branch letter within the shield. For example, from 1865 to 1871 commissioned officers of all branches wore a frock coat with 9 (lieutenants and captains) or 14 (higher ranks) eagle buttons. Large eagle buttons also were present at the rear of the waist seam. During this time, enlisted cavalrymen wore a shell-type uniform jacket with 12 cuff-sized brass eagle buttons in a single row down the front. On both sides of the standing collar were two blind buttonholes of lace, each terminating in a small eagle button. Even the 1858 pattern uniform dress hat for both branches had a leather chin strap fastened at each end by a small regulation eagle button. The 1872 pattern full-dress coat for line officers had either seven or nine large eagle buttons down the front. The cuffs were closed with three small gilt eagle buttons. The 1872 pattern overcoat for commissioned officers closed with two rows of large eagle buttons bearing the branch letter (McChristian 1995:12-14, 46, 50).

Coat-sized (approximately $23 \mathrm{~mm}$ diameter) buttons were worn on the uniform coat and overcoat, as well as on sleeves, pockets, and collars; and cuff-sized (approximately $15 \mathrm{~mm}$ diameter) buttons were worn on the cuff, vest, jacket, shoulder straps, pocket flaps, and cap. Button designs originated in the office of the Quartermaster Department after the 1840s (Brinckerhoff 1976: 1-2; Johnson 1948:19). 
General service buttons recovered at the fort are 2 great coat eagle and wreath, 1 standing eagle, and 20 line eagle devices. Summary information on these buttons is presented in Table 5, which is sorted by size and manufacturer. The great coat buttons occur only in coat size, the standing eagle only in a cuff size, and the line eagle in both coat and cuff sizes. Also present are 2 cuff-sized staff officer buttons. The line eagle device with a letter in the shield designated the branch of service, and 4 infantry coat buttons and 1 dragoon cuff button were found.

Coat button assemblage diameters range from 19.2 to $24.6 \mathrm{~mm}$, and cuff button diameters range from 13.9 to $15.4 \mathrm{~mm}$. Some of this variation probably results from different manufacturers and other variation from postdepositional crushing, which in flattening the convex front would tend to produce a measurement larger than the original button's size. The three line eagle coat buttons by Scovill Manufacturing Co. occur in 20.1- and 20.4-mm sizes, and the Waterbury Button Co. example is $20.5 \mathrm{~mm}$.

All of the buttons are made of yellow metal, which emphasizes the gilded or plated surface color rather than the base metal, which could include copper alloys, such as brass, as well as other alloys and scrap metals which varied widely

\begin{tabular}{|c|c|c|}
\hline & & $\begin{array}{c}\text { TABLE } 5 \\
\text { MILITARY BUTTONS }\end{array}$ \\
\hline $\begin{array}{l}\text { Diameter } \\
(\mathrm{mm})\end{array}$ & Type & Backmark \\
\hline $\begin{array}{l}\text { Coat } \\
19.6 \\
20.2 \\
19.2 \\
19.3 \\
19.4 \\
19.6 \\
19.9 \\
20.1 \\
20.2 \\
20.2 \\
20.4 \\
20.4 \\
20.5 \\
21.3 \\
21.9 \\
19.2 \\
20.7 \\
23.0 \\
24.6\end{array}$ & $\begin{array}{l}\text { great coat, omega type } \\
\text { great coat, omega type } \\
\text { line eagle } \\
\text { line eagle } \\
\text { line eagle } \\
\text { line eagle } \\
\text { line eagle } \\
\text { line eagle } \\
\text { line eagle } \\
\text { line eagle } \\
\text { line eagle } \\
\text { line eagle } \\
\text { line eagle } \\
\text { line eagle } \\
\text { line eagle } \\
\text { infantry } \\
\text { infantry } \\
\text { infantry } \\
\text { infantry }\end{array}$ & $\begin{array}{l}\text { UNITED *.**/**** STATES (raised) } \\
\text { UNITED } * . * * * * \text { STATES (raised) } \\
\text { EXTRA } * * * * * * * \text { QUALITY (impressed) } \\
\text { None } \\
\text { None } \\
\text { EXTRA/QUALITY (impressed) } \\
\text { illegible } \\
\text {.SCOVILL MFG CO./WATERBURY (raised mark in depressed channel) } \\
\text { EXTRA ***/*** QUALITY (impressed) } \\
\text { illegible } \\
\text {.SCOVILL MFG CO./WATERBURY (raised mark in depressed channel) } \\
\ldots \text {. OVILL MFG CO./... URY (raised mark in depressed channel) } \\
\text { WATERBURY BUTTON CO. (raised) } \\
\text { illegible } \\
\text {.. BROS ... (impressed) } \\
\text {.SCOVILLS./WATERBURY (raised mark in depressed channel) } \\
\text { EXTRA/QUALITY (impressed) } \\
\text { illegible } \\
\text { D. EVANS \& CO.*/*ATTLEB[ORO] MASS (impressed) }\end{array}$ \\
\hline $\begin{array}{l}\text { Cuff } \\
13.9 \\
14.8 \\
14.9 \\
15.5 \\
14.5 \\
14.7 \\
14.8 \\
14.7 \\
13.4 \\
15.0 \\
15.4\end{array}$ & $\begin{array}{l}\text { standing eagle } \\
\text { line eagle } \\
\text { line eagle } \\
\text { line eagle } \\
\text { line eagle } \\
\text { line eagle } \\
\text { line eagle } \\
\text { line eagle } \\
\text { dragoon } \\
\text { staff officer } \\
\text { staff officer }\end{array}$ & $\begin{array}{l}\text { None } \\
\text { None } \\
\text { None } \\
\text { W.H. HORSTMANN \& SONS (raised mark in depressed channel) } \\
\text { None } \\
\text { WATERBURY BUTTON. (impressed) } \\
\text { WATERBURY BUTTON C . (impressed) } \\
\text { None } \\
\text { SCOVILLS \& CO/EXTRA (impressed) } \\
\text { SCOVILL MFG CO../WATERBURY (impressed) } \\
\text { illegible }\end{array}$ \\
\hline
\end{tabular}


in composition (Johnson 1948:6). Unless otherwise specified, all of the buttons are Sanders's type, consisting of a convex front, a backing or shank plate, and a loop shank. Benjamin Sanders of Birmingham, England, a major metal and shell button manufacturing location for three centuries, invented a three-part button in 1823. The front could easily be stamped with a design or insignia prior to construction, and the backplate often bore a manufacturer's mark (Pool 1987:277-279).

Eleven of the buttons have legible makers' marks, although additional nonspecific Extra Quality backmarks are present. There are six Scovill, three Waterbury, one Evans, and one Horstmann \& Sons buttons. These are discussed below under their respective types.

The general service great coat buttons were omega type in two patterns. The body was blanked out from a sheet of rolled metal, forming a flat front, and the loop shank footed to form a point of attachment similar to the Greek letter omega. One pattern (Figure 50a) is Johnson's (1948:65) \#255 with wreath berries and arrows pointing outward, and the other (Figure $50 \mathrm{~b}$ ) is Johnson's (1948:65) \#256 without wreath berries and with arrows pointing inward. This button was an early, and perhaps the first, general service button for officers and men not in one of the combat arms or on detached service. These button patterns were in use from the early 1820 s through the 1850s (Black and Ing 1980:267). Based on finds at 1857 Pima villages along the Gila River in Arizona and at mid-1860s sites in Wyoming, these buttons may have been worn as late as the Civil War, although other designs had superseded these patterns by then (Brinckerhoff 1976:2). The United States backmark occurs on 1820s army general service buttons with varying numbers of stars. This backmark type was ordered as late as 1839 (McGuinn and Bazelon 1990:104).

A general service standing eagle device cuff button is of Sanders's type but with a flat front similar to the omega type, which is the usual manufacture type for this pattern. Johnson (1948:66) describes the standing eagle device (\#257C) with a large blank shield at its left side against a lined field as occurring on omega-type buttons. The standing eagle with side shield was used on the 1839 pattern forage cap, widely used during the Mexican War and probably into the 1850s (Brinckerhoff 1976:3, Figure 1, upper right).

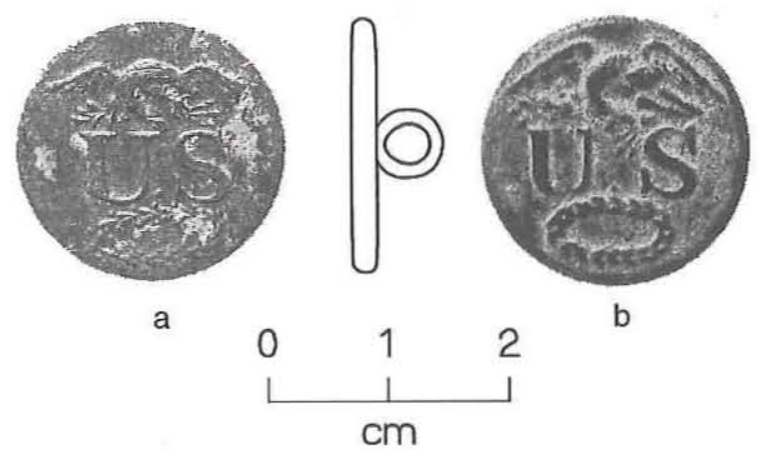

Figure 50. Great coat buttons. (a) With wreath berries and with arrows pointing outward; $(b)$ without wreath berries and with arrows pointing inward.

Thirteen coat buttons and seven cuff buttons with the general service line eagle device were recovered. Line eagle buttons were authorized in January 1854 and were issued to all enlisted men from 1855 until 1902 (Herskovitz 1978:39).

Four identifiable makers' marks are present on the line eagle coat buttons. Three of these are identical marks from the Scovill Manufacturing Company in Waterbury, Connecticut. The mark (Figure $51 a$ ) is most similar to the $1850-1870$ mark in McGuinn and Bazelon (1990:87), although it lacks the apostrophe in "MF'G." The mark with the apostrophe occurs on many different United States and state militia buttons with raised marks in depressed channels like these dating ca. 1850-1860 (McGuinn and Bazelon 1990:92). The fourth mark is from the Waterbury Button Company. The mark does not match any of the photographs in McGuinn and Bazelon (1990:108). The company was in business under this name from 1849 to 1944 , and a similar mark with large letters postdates the Civil War and occurs on many different buttons (McGuinn and Bazelon 1990:107).

Three identifiable makers' marks are present on line eagle cuff buttons. Two of these are from the Waterbury Button Company. As with the coat button above, this mark (Figure $51 b$ ) may be the one postdating the Civil War. The third mark is from W. H. Horstmann \& Sons, and, in lacking the location, does not match any of the examples in the text. Horstmann \& Son and Horstmann \& Sons were in business in Philadelphia from 1843 to 1859 and in co-existence with Horstmann Bros. \& Co. until 1893 (Bazelon and McGuinn 1990:67-68; Jacobsen 1972; McGuinn and Bazelon 1990:57). 


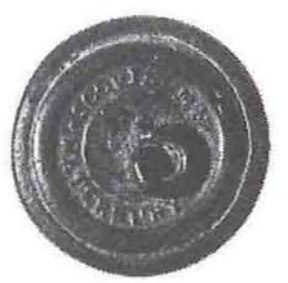

a
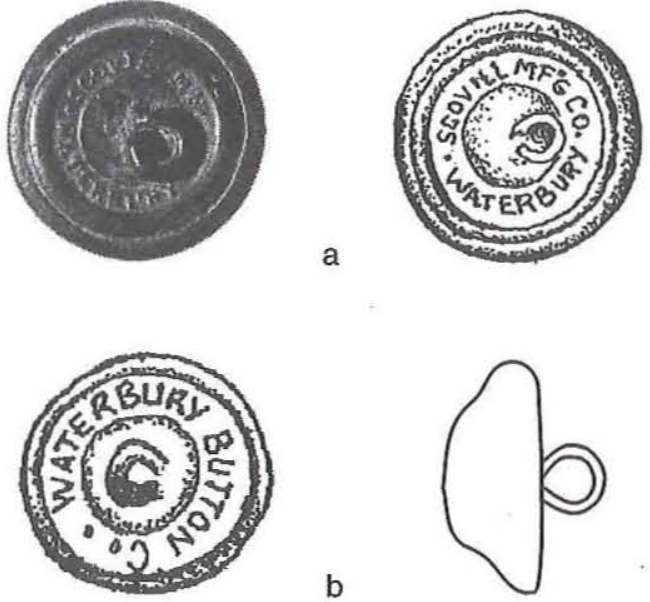

b

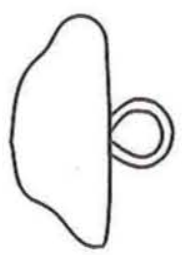

C

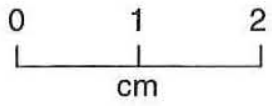

Figure 51. Line eagle buttons. (a) Scovill Manufacturing Co. coat button; (b) Waterbury Button Co. cuff button; $(c)$ cuff button with recessed shield and long narrow wings.

Since only 37 percent of the buttons have legible makers' marks, attributes of the line eagle patterns relevant to dating are discussed. The line eagle pattern differed slightly on enlisted men's specialized service buttons from the 1840 s and 1850 s. The button from 1855 to 1884 featured a wide recessed and lined shield and narrow and long eagle's wings. From 1884 until 1902, the shield was raised and smaller and the eagle generally had short, wide wings. Cuff buttons with the later raised shield occur with both wide and narrow wings, however (Herskovitz 1978:39). The 10 coat- and 6 cuff-sized general service line eagle buttons legible enough to discern pattern details all appear to be from the 1855-1884 pattern (Figure 51c) with recessed shield and long narrow wings (Brinckerhoff 1976:5, Figure 4, upper left). The relatively little variation in line eagle patterns for this fort is consistent with the end of the military occupation in 1883 and supports the general temporal differences indicated below.

Variations that have been assigned temporal significance could also reflect differences in manufacturing and slight modifications in design specifications, as noted by Brinckerhoff (1976:4). Another practice was continued issuance of outdated button patterns. Obsolete $1830 \mathrm{~s}-1850 \mathrm{~s}$ button patterns often are recovered in considerable quantities at army posts of the immediate pre-Civil War period. Apparently, a great deal of obsolete uniform materials continued to be issued as much as 10 years after newer designs were specified. When new designs were authorized, army orders usually directed that older designs were to be issued and worn until the existing stock was exhausted (Brinckerhoff 1976:3). General support for the temporal differences is provided by drawings in Schuyler, Hartley \& Graham's (1864:71) catalog of Civil War goods and in Horstmann Bros. \& Co.'s catalog for 1877 (Military Buttons page, \#8 [Artillery], \#8 [Cavalry], \#128 [Infantry], and U.S. Coat), although the drawings also reflect some variation, probably due to different manufacturers.

Two staff officer cuff buttons were recovered. Staff-type buttons originated in the early 1830 s and consisted of four parts: the high-domed front, the flat back, the rim connecting the two, and the loop shank. In addition to first and continuous use by general staff from 1832 to 1902 , this was the most popular type for uniforms in the late nineteenth century (Johnson 1948:14-15). These buttons, usually worn by medical, quartermaster, and signal officers, have a line eagle device surrounded by a circle of stars varying from 13 to 30 in number. The field is horizontally lined. From 1832 to 1872 the center shield is vertically lined only, and from 1872 to 1902 the center shield is vertically lined with from 7 to 13 small stars at the top of the shield (Brinckerhoff 1976:6-7, Figure 5, left). The 1877 Horstmann Bros. \& Co. catalog (Staff, \#62), however, shows the upper shield as blank rather than containing stars or horizontal lines. One example with a ferrous metal back from the fort has horizontal lines at the top of the shield and vertical lines below (Figure 52), a design illustrated in Schuyler, Hartley \& Graham's (1864:71, No. 169) Civil War goods catalog, and the other may have stars at the top but is too corroded to be positive.

Use of the line eagle device to designate 

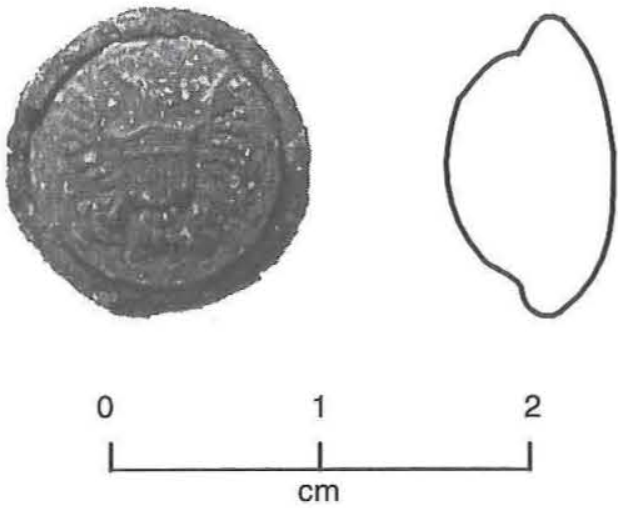

Figure 52. Staff officer button.

branch of service was adopted as early as 1821 by artillery and infantry for both officers and enlisted men. The 1851 regulations specified sizes for enlisted men of $3 / 4$ inch $(19 \mathrm{~mm})$ and for officers of $7 / 8$ inch $(22 \mathrm{~mm})$, and its use was restricted to officers in 1854 (Herskovitz 1978:39-40). Its raised lined shield distinguished the officers' specialized service button dating from the late 1880 s to 1902 from the earlier recessed shield version (Brinckerhoff 1976:3-5).

Two of the four infantry coat buttons have makers' marks. The Scovills button (Figure 53a) matches a description for Scovills \& Co., in business from 1840 to 1850 . Cuff-sized buttons with the Scovills backmark are common on Civil War shell-type jackets and are believed to result from continued use of Scovills \& Co. backplate dies by the firm's successor, Scovill Manufacturing Company (McGuinn and Bazelon 1990:90-91). The 19-mm Scovills is small enough and probably early enough to represent an enlisted man's button, but the others presumably are all officers' buttons, since the order restricting the use of these buttons to officers was published only a year after the fort was established (Herskovitz 1978:39-40). The D. Evans \& Co. button (Figure $53 b$ ) occurs on many different buttons dating from 1850 to 1880 (McGuinn and Bazelon 1990:36). The diameters given for the Evans and illegible buttons probably are overestimates since these two buttons are crushed. All of these buttons have recessed (or at least not raised) shields, indicating post- 1840 dates. Details of the eagle are visible on only three of the specimens. The eagle on the Scovills button resembles the 1840 s enlisted pattern in Brinckerhoff (1976:Figure 1, lower left). The other two eagles most closely match the 1850 s enlisted
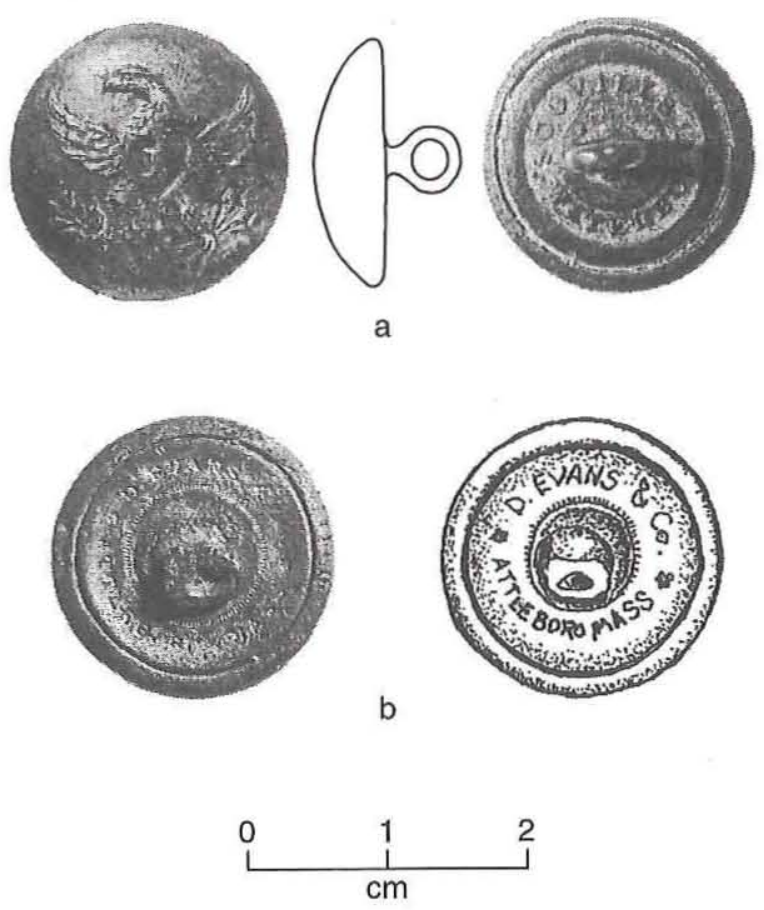

Figure 53. Infantry buttons. (a) Scovills \& Co. front and back; (b) D. Evans \& Co. (back only).

pattern button in Brinckerhoff (1976:Figure 1, lower right).

A dragoon cuff button (Figure 54) with a Scovills \& Co. mark, as with the infantry button, probably postdates the $1840-1850$ operation dates of Scovills \& Co. This button probably dates to the $1850 \mathrm{~s}$, as the dragoons were merged with the cavalry in 1861 (Townsend and Todd 1956:5).

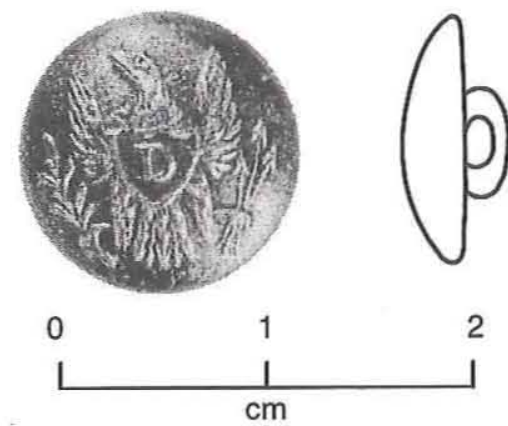

Figure 54. Scovills \& Co. dragoon button.

\section{Equipment or Equipage}

\section{Canteen Stopper}

A canteen stopper (Figure 55) from the Barracks 3 shed consists of the ferrous metal stopper, 


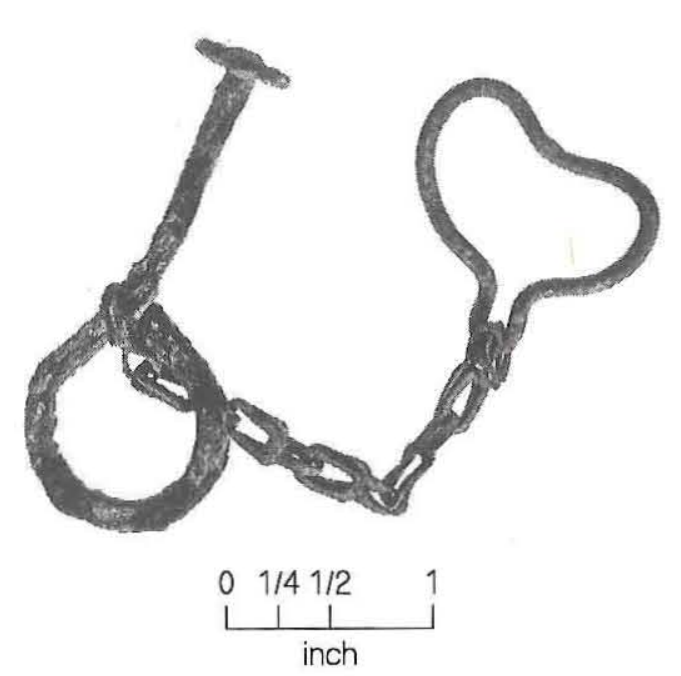

Figure 55. Canteen stopper.

a brass chain for attaching the stopper to the neck of the canteen, and a brass neck ring. A finger ring at one end of the stopper was used to remove the cork, which formerly was attached to the $1 \frac{1}{1 / 8}$ inch shank. The brass chain is the short $2 \frac{1}{2}$-inch length to attach to the neck ring rather than to one of the sling loops. The neck ring, rather than being a twist of wire, was made of heavy brass wire pinched at one point to form a loop for the chain and at the same time to tighten the ring around the spout. These attributes identify the stopper as part of the 1874 pattern Type 3 canteen probably standardized during 1877 . This type of neck ring with chain may be found on any of the earlier canteens since it would have been applied to canteens turned in for reconditioning with missing or broken chains (McChristian 1995: 211-212).

\section{Carbine Sling Swivel}

A carbine sling swivel with snap hook was found in Officers' Quarters 4, Room 0. The carbine sling - a black bridle or white buff leather belt $2 \frac{1}{2}$ inches wide and 56 inches long with a large iron swivel and snap hook-was intended to prevent the trooper from losing the carbine while mounted. Sliding freely on the sling was an iron swivel made of four parts: the swivel itself, consisting of a roller and an iron wire eye approximately $3 / 4$ inch in diameter, a link $2 \frac{1}{4}$ inches long, and the hook, measuring $4 \frac{1}{4}$ inches long. Only the $2 \frac{1}{2}$-inch-wide ferrous metal swivel is present. The sling went over the left shoulder, the ring on the carbine was snapped into the swivel, and the weapon was left to dangle behind the soldier's right leg. This arrangement, although an obvious safety hazard to the mounted soldier, ensured that he could neither drop his weapon nor become separated from it should his horse be shot. Many cavalrymen instead carried the carbine across the pommel of the saddle, generally secured by a leather loop, as was common for civilian plainsmen and Native Americans. The standard carbine sling was used in the post-Civil War period and remained in use by units that did not have the brace equipment approved in 1872 (Huntington 1967: 350-351; Hutchins 1976:33; McChristian 1995:29).

\section{Knapsack Hardware}

Three hardware items from an M1853 knapsack were found in the east yard of Officers' Quarters 4 (two) and in the highway right-of-way. The M1853 knapsack was made of heavy duck canvas painted with a waterproof gutta-percha covering and was used officially until 1872. A metal alloy hook $13 / 8$ inches long by $1 \frac{1}{2}$ inches wide is from the lower exterior of the knapsack carried against the soldier's back attached to the shoulder straps. A metal alloy triangle $1 \frac{1}{4}$ inches on a side was attached to one of the shoulder straps and connected with the hook at the lower exterior of the knapsack (Katcher 1989:20-21). This triangular ring is listed (No. 639) under belt mountings in Horstmann Bros. and Co.'s 1877 military goods catalog. In 1855 the chest straps were made with hooks that fastened into the slots in the M1855 rifleman's belt (Katcher 1989:21). This cuprous metal hook measures $15 / 8$ inches long. Similar examples were found during the 1974-1977 archeological work at the fort (Black and Ing 1980:Figure 76e).

\section{Buckles}

Three buckles may be from the military occupation. A cuprous metal buckle clasp from the Old Hospital is $21 / 8$ inches high and $11 / 8$ inches wide. The back is impressed " 442 2." The clasp size and shape matches the $2 \frac{1}{8}-$-inch-high cast brass waist belt used by infantry soldiers in 1872 equipment trials (McChristian 1995:84). A metal alloy 
roller buckle $13 / 4$ inches long and approximately 1 inch wide may have been used on the 1872 pattern haversack, the flap of which was fastened by a $3 / 4$-inch-wide webbing strap with three brass eyelets to a brass wire buckle. The clearance for a strap inside the buckle is $3 / 4$ inch wide. A ferrous metal buckle clasp is $2 \frac{3}{4}$ inches high and $1 \frac{1}{2}$ inches wide. It cannot be identified with published military-issue hardware.

\section{Mess Kit or Table Fork}

A three-tined ferrous metal fork fragment with a handle that is double concave in cross section was found in the south yard of Officers' Quarters 4. The tines are $3 / 4$ inch wide, and the handle is $5 / 8$ inch wide; the fragment is 4 inches long and unmarked. The fork is similar to the 1874 pattern fork shown in McChristian (1995:Figure 174) but is fragmentary and considerably corroded. The styles of knives, forks, and spoons varied widely owing to the great many styles available on the commercial market. The knives and forks purchased by soldiers were usually iron with plain, two-piece wooden handles riveted to the shanks with two or three brass pins. Forks were made in both three- and four-tine styles, the former being the more common. Forks averaged about 7 inches long. The army began issuing utensils and a tin cup to each soldier in 1875 . Both the knife and the fork were made of steel with nearly indestructible cast-iron handles and were stamped "U.S." or "U.S.A." The 1874 pattern fork had three tines and a cast-iron handle. Overall length was $71 \frac{1}{2}$ inches. When present, "U.S." or "U.S.A." markings appeared on the reverse of the shank, between the handle and the tines (McChristian 1995:101, $187,214-215)$.

\section{Horse Equipment}

A bit ornament from the east yard of Officers' Quarters 4 is from the Civil War-era cavalry curb bit or 1885 Shoemaker bit. Although the 1876 military-issue bit was devoid of ornaments, a steel curb bit described in the 1861 Ordnance Manual and pictured in Huntington (1967:Figure 6b) and a bronzed U.S. bit pictured in an 1864 military goods catalog (Schuyler, Hartley \& Graham $1864: 76$, No. $224 \frac{1}{2}$ ) appear to be identical to this specimen. The 1885 specifications required that each bit have two ornaments of cast brass containing raised U.S. letters riveted to the ends of the mouthpiece. This example is 2.16 inches long and 1.28 inches wide. It does not have the square period following the "U" as some reported specimens do (Herskovitz 1978:84-85; Hutchins 1976:40, Figures 25 and 26).

\section{MIILITARY-PERIOD ARTIFACTS}

\section{Kitchen Artifacts and Containers}

\section{Ceramics}

The temporally diagnostic ceramic assemblage consists of 88 sherds, 84 of which are whitewares, 2 are yellowwares, and 2 are stonewares. The whiteware sherds are 64 white earthenware, 13 semivitreous whiteware, 6 vitreous but not translucent whiteware, and 1 porcelain.

Seven of the sherds have marks. Two of these are undecorated whitewares, and three are decorated whitewares; both of the stoneware sherds are marked. The unmarked stoneware was not analyzed since the date ranges are too broad for the mid-to-late-nineteenth-century period under consideration.

Eighty-two of the whitewares are decorated. Whiteware decoration types are discussed under the primary form of decoration for sherds with more than one type (e.g., enameled and molded or flow printed and enameled). Relatively infrequent types are edged $(n=7)$, sponged $(n=6)$, decal $(n=6)$, and annular $(\mathrm{n}=2)$. Three sherds are underglaze hand painted, and 11 sherds are overglaze hand enameled. The 19 flow-printed sherds represent 23 percent of the decorated assemblage, and the 24 transfer-printed sherds represent 29 percent. Three molded sherds and one sherd with colored decoration of unknown type also are present.

The ceramic assemblage is summarized in Table 6. Because of the small size of most of the sherds, vessel form is difficult to identify and is noted with question marks where uncertain. Marks and decoration types that are temporally diagnostic are discussed below.

\section{MARKS}

A red transfer-printed unscalloped saucer rim is marked with a combined printed "E.M. \& 


\begin{tabular}{|c|c|c|c|c|c|c|c|c|c|c|}
\hline & & EMPORA & DIAG & $\begin{array}{l}\text { BLE } 6 \\
\text { OSTIC C }\end{array}$ & AMIC SH & & & & & \\
\hline Decoration Type/Color/Pattern & Plate & Platter & Cup & Saucer & Teaware & Bowl & Lid & Hollowware & Bottle & Unknown \\
\hline $\begin{array}{l}\text { Molded } \\
\text { Floral } \\
\text { Foliate } \\
\text { Ribbed }\end{array}$ & $\begin{array}{l}- \\
- \\
-\end{array}$ & $\begin{array}{l}- \\
- \\
-\end{array}$ & $\begin{array}{l}- \\
- \\
-\end{array}$ & $\begin{array}{l}- \\
- \\
-\end{array}$ & $\begin{array}{l}- \\
- \\
-\end{array}$ & $\begin{array}{l}- \\
- \\
-\end{array}$ & $\begin{array}{l}1 ? \\
1 ? \\
-\end{array}$ & $\begin{array}{l}- \\
- \\
-\end{array}$ & $\begin{array}{l}- \\
- \\
-\end{array}$ & $\begin{array}{l}- \\
\overline{1} \\
\end{array}$ \\
\hline Edged, Blue Shell & 7 & - & - & - & - & - & - & - & - & - \\
\hline Annular, Polychrome Banded & - & - & - & - & - & $1 ?$ & - & - & - & - \\
\hline Annular?, Polychrome Swirl? & - & - & - & - & - & - & - & - & - & 1 \\
\hline $\begin{array}{l}\text { Sponge Stamped, Polychrome } \\
\text { Floral } \\
\text { Floral? }\end{array}$ & - & - & - & $\begin{array}{l}1 \\
1\end{array}$ & - & $\overline{-}$ & $\begin{array}{l}- \\
-\end{array}$ & - & - & - \\
\hline Sponge Spatter, Blue & - & - & 1 & - & - & - & - & - & - & 1 \\
\hline Open Sponge, Blue & - & - & - & - & - & $1^{*}$ & - & - & - & 1 \\
\hline $\begin{array}{l}\text { Painted } \\
\text { Brown Banded } \\
\text { Red Thickline Floral } \\
\text { Polychrome }\end{array}$ & $\begin{array}{l}- \\
- \\
-\end{array}$ & $\begin{array}{l}- \\
- \\
-\end{array}$ & $\begin{array}{l}\overline{1} \\
1\end{array}$ & $\begin{array}{l}- \\
- \\
-\end{array}$ & $\begin{array}{l}- \\
- \\
-\end{array}$ & $\begin{array}{l}- \\
- \\
-\end{array}$ & $\begin{array}{l}- \\
- \\
-\end{array}$ & $\begin{array}{r}1 * * \\
- \\
-\end{array}$ & $\begin{array}{l}\overline{-} \\
\overline{-}\end{array}$ & $\begin{array}{l}- \\
- \\
-\end{array}$ \\
\hline $\begin{array}{l}\text { Enameled } \\
\text { Copper Tea Leaf Luster } \\
\text { Pink Luster with Molded Flutes } \\
\text { Polychrome } \\
\text { Floral } \\
\text { Floral? } \\
\text { Luster } \\
\text { Unknown } \\
\text { Silver? Luster with Molded Scroll }\end{array}$ & $\begin{array}{l}- \\
- \\
- \\
- \\
- \\
\overline{1}\end{array}$ & $\begin{array}{l}- \\
- \\
- \\
- \\
- \\
- \\
-\end{array}$ & $\begin{array}{l}2^{* * *} \\
1 \\
1 ? \\
- \\
- \\
-\end{array}$ & $\begin{array}{l}- \\
- \\
- \\
- \\
- \\
-\end{array}$ & $\begin{array}{l}1 \\
- \\
- \\
- \\
- \\
- \\
-\end{array}$ & $\begin{array}{l}- \\
- \\
- \\
- \\
- \\
-\end{array}$ & $\begin{array}{l}- \\
- \\
- \\
- \\
- \\
- \\
-\end{array}$ & $\begin{array}{l}\overline{-} \\
- \\
\overline{1} \\
\overline{3} \\
-\end{array}$ & $\begin{array}{l}- \\
- \\
- \\
- \\
- \\
-\end{array}$ & $\begin{array}{l}- \\
- \\
- \\
- \\
1 \\
- \\
-\end{array}$ \\
\hline $\begin{array}{l}{ }^{*} \text { Crock/bowl? } \\
{ }^{* *} \text { Teapot? } \\
\text { ***1 is a handled cup }\end{array}$ & & & & & & & & & & \\
\hline
\end{tabular}




\begin{tabular}{|c|c|c|c|c|c|c|c|c|c|c|}
\hline \multicolumn{11}{|l|}{ Table 6, continued } \\
\hline Decoration Type/Color/Pattern & Plate & Platter & Cup & Saucer & Teaware & Bowl & Lid & Hollowware & Bottle & Unknown \\
\hline $\begin{array}{l}\text { Flow } \\
\text { Blue } \\
\text { Floral } \\
\text { Floral? } \\
\text { Floral/scroll } \\
\text { Unknown } \\
\text { Polychrome (with enamel) } \\
\text { Floral or Scenic } \\
\text { Scenic }\end{array}$ & $\begin{array}{l}\overline{-} \\
\overline{-} \\
1^{*} \\
- \\
-\end{array}$ & $\begin{array}{l}- \\
\overline{2} \\
- \\
- \\
-\end{array}$ & $\begin{array}{l}1 ? \\
- \\
- \\
- \\
- \\
-\end{array}$ & $\begin{array}{l}2 \\
1 ? \\
- \\
1 \\
1 ? \\
1 ?\end{array}$ & $\begin{array}{l}- \\
- \\
- \\
- \\
- \\
-\end{array}$ & $\begin{array}{l}- \\
- \\
- \\
- \\
-\end{array}$ & $\begin{array}{l}- \\
- \\
- \\
-\end{array}$ & $\begin{array}{l}- \\
- \\
- \\
- \\
- \\
-\end{array}$ & $\begin{array}{l}- \\
- \\
- \\
- \\
-\end{array}$ & $\begin{array}{l}2 \\
- \\
\overline{7} \\
- \\
-\end{array}$ \\
\hline $\begin{array}{l}\text { Transfer } \\
\text { Black Bird } \\
\text { Blue } \\
\text { Priory } \\
\text { Willow } \\
\text { Floral } \\
\text { Geometric } \\
\text { Unknown } \\
\text { Brown } \\
\text { Floral } \\
\text { Foliate } \\
\text { Geometric/floral } \\
\text { Unknown } \\
\text { Brown? Foliate } \\
\text { Red } \\
\text { Verona } \\
\text { Floral } \\
\text { Unknown }\end{array}$ & $\begin{array}{l}- \\
1 \\
1 ? \\
2 \\
- \\
1 ? \\
2 \\
1 \\
- \\
1 ? \\
- \\
1 \\
- \\
-\end{array}$ & $\begin{array}{l}1 \\
1 \\
- \\
- \\
- \\
- \\
- \\
- \\
- \\
- \\
- \\
- \\
- \\
-\end{array}$ & $\begin{array}{l}- \\
- \\
- \\
- \\
- \\
- \\
- \\
- \\
- \\
- \\
1 \\
- \\
2 \\
-\end{array}$ & $\begin{array}{l}- \\
- \\
1 ? \\
1^{* *} \\
1 ? \\
- \\
1 \\
- \\
- \\
- \\
- \\
2^{* * *} \\
- \\
-\end{array}$ & $\begin{array}{l}- \\
- \\
- \\
- \\
- \\
- \\
- \\
- \\
- \\
- \\
- \\
- \\
- \\
-\end{array}$ & $\begin{array}{l}- \\
- \\
- \\
- \\
- \\
- \\
- \\
- \\
- \\
- \\
- \\
-\end{array}$ & $\begin{array}{l}- \\
- \\
- \\
- \\
- \\
- \\
- \\
- \\
1 \\
- \\
- \\
- \\
-\end{array}$ & $\begin{array}{l}- \\
- \\
- \\
- \\
- \\
- \\
- \\
- \\
- \\
- \\
- \\
- \\
- \\
-\end{array}$ & $\begin{array}{l}- \\
- \\
- \\
- \\
- \\
- \\
- \\
- \\
- \\
- \\
-\end{array}$ & $\begin{array}{l}- \\
- \\
- \\
- \\
- \\
1 \\
- \\
- \\
- \\
- \\
- \\
- \\
- \\
-\end{array}$ \\
\hline $\begin{array}{l}\text { Decal } \\
\text { Green } \\
\text { Floral } \\
\text { Foliate } \\
\text { Polychrome Floral }\end{array}$ & $\begin{array}{l}- \\
\overline{1}\end{array}$ & $\begin{array}{l}- \\
- \\
-\end{array}$ & $\begin{array}{l}- \\
- \\
-\end{array}$ & $\begin{array}{l}- \\
1 \\
3^{* * *}\end{array}$ & $\begin{array}{l}- \\
- \\
-\end{array}$ & $\begin{array}{l}- \\
-\end{array}$ & $\begin{array}{l}- \\
- \\
-\end{array}$ & $\begin{array}{l}- \\
-\end{array}$ & $\begin{array}{l}- \\
-\end{array}$ & $\begin{array}{l}1 \\
- \\
-\end{array}$ \\
\hline $\begin{array}{l}\text { *Plate or platter? } \\
* * \text { Plate or saucer } \\
* * * 1 \text { is saucer? }\end{array}$ & & & & & & & & & & \\
\hline
\end{tabular}




\begin{tabular}{|c|c|c|c|c|c|c|c|c|c|c|}
\hline \multicolumn{11}{|l|}{ Table 6, continued } \\
\hline Decoration Type/Color/Pattern & Plate & Platter & Cup & Saucer & Teaware & Bowl & Lid & Hollowware & Bottle & Unknown \\
\hline Unknown, Polychrome & - & - & - & - & - & - & - & - & - & 1 \\
\hline Undecorated & - & - & - & - & - & - & - & - & - & 2 \\
\hline Salt Glaze & - & - & - & - & - & - & - & - & 2 & - \\
\hline Flint Enamel, Brown & - & - & - & - & - & - & - & - & - & 1 \\
\hline Colored Lead Glaze, Brown & - & - & - & - & - & - & - & - & - & 1 \\
\hline
\end{tabular}


Co./B" maker's and "TRADEMARK/VERONA" pattern mark (Figure 56). The Verona pattern was made by Edge Malkin \& Co. (Williams 1978:454). Edge Malkin \& Co. of Burslem manufactured earthenwares from 1871 to 1903 . The lack of "Ltd." in the company name indicates manufacture before 1899. Distinguishing initials such as the "B" are found on printed marks of differing design that often included the pattern name. This mark is similar to Godden's (1964:230) Mark 1445, dated ca. 1873-1903, but with the pattern name occurring inside the banner and the maker printed below the banner instead of the maker occurring inside the banner as shown. Thus, the date range for this mark is $1873-1899$.
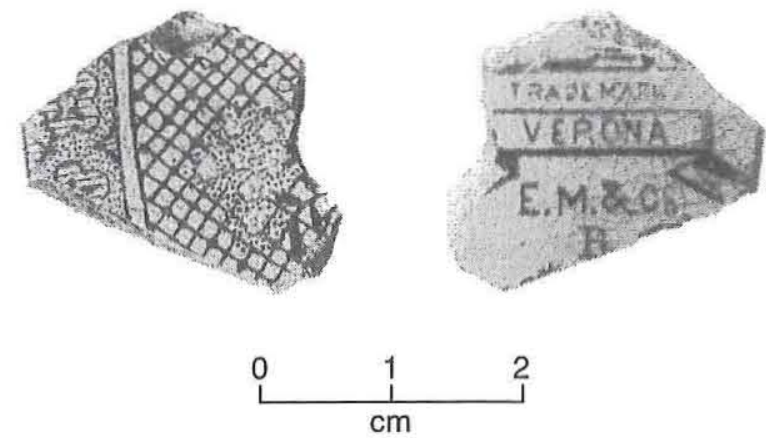

Figure 56. Front and back of red-printed whiteware with Edge Malkin \& Co. maker's and Verona pattern mark.

An enameled tea leaf luster teaware base is marked with a green-printed "WEDG . . ./E . .." below a fragment of a shield, oval, or cartouche. This mark does not match any of the British examples in Godden (1964) but could be from Wedgwood \& Co. (1860-present), J. Wedgwood [John Wedge Wood] (1841-1860), Josiah Wedgwood (\& Sons, ca. 1759-present), or possibly Podmore, Walker \& Co. (1834-1859) (Godden 1964:501, 655-662, 687). American possibilities include the Wedgewood Pottery operating in East Liverpool, Ohio, from 1877 until 1881, when it was sold to Wallace and Chetwynd (Gates and Ormerod 1982:79). If the "E . .." is from the word "ENGLAND" (e.g., "ETRURIA," the location in England of Josiah Wedgwood's pottery, is another possibility), then the mark probably postdates the 1891 American McKinley Tariff Act (Godden 1964:239). Tea leaf luster patterns were introduced in the $1850 \mathrm{~s}$ and peaked in popularity between 1880 and 1900 (Majewski and O'Brien
1987:160). In summary, the decorative pattern provides a narrower date for this sherd than does the mark, which was used by many different companies following the great success of Josiah Wedgwood.

An undecorated semivitreous whiteware is marked with a black-printed maker and Royal Arms mark. Below the Royal Arms is "ROYAL/ PATENT IRONSTONE/BURGESS \& GODDARD." This mark is not identified in DeBolt (1988), Godden (1964), Gates and Ormerod (1982), Lehner (1988), and others. Collections from Old Sacramento, California, identify this Longton, Staffordshire, firm as active in the 1870 s and 1880 s, including importing ceramics through its New York, Boston, Philadelphia, and Baltimore outlets and representing such firms as John Edwards, Wedgwood \& Co., and Bridgwood \& Son (Praetzellis et al. 1983:17). This firm is represented by 1870 s ironstone or white granite vessels in Wetherbee (1985:136-137).

A white earthenware flow blue saucer (?) body sherd has a printed mark ". . . AIN" probably describing the ware with a term such as semiporcelain, although it could also be part of a pattern or maker's name.

A semivitreous undecorated whiteware base has a black printed maker's mark ". . . KIN" below a fragment of a Royal Coat of Arms mark. The maker is probably one of the Meakin potteries, and the closest match in placement of letters with published illustrations is Charles Meakin, 18831889 (Mark 2596) and J. \& G. Meakin, 1851present (Mark 2601 dates ca. 1890+) (Godden 1964:424-427).

An exterior salt-glazed, tan, wheel-thrown stoneware bottle base fragment with an impressed maker's mark of "GROSVENOR [at top of oval]/ GLASGOW [at bottom of oval]/20 [in center]" was made by the F. Grosvenor pottery in Glasgow, Scotland, from ca. 1869-1899. Frederick's son became an owner at the turn of the century, and the absence of "\& Son" probably dates the bottle to the nineteenth century (Godden 1964:295). Similar marks with different numbers (marking the pottery lot?) occurred on a bottle at Fort Laramie (Wilson 1981:130) and a bottle at Fort Bowie (Herskovitz 1978:113). Although the bottle is salt glazed, as was common in the early nineteenth century, the finish is shiny and vitreous, a trait common in the second half of the century, when 
the mark indicates the bottle was produced. This bottle may have contained ginger beer, ale, stout, or possibly beer (Herskovitz 1978:115; Munsey 1970:135; Wilson 1981:7).

A salt-glazed, tan, molded stoneware bottle body fragment with an impressed maker's mark consisting of an anchor incorporating the numeral " 4 " into the shank and stock and the words ". . . OLLINARIS . . .M.W." (Figure 57) could not be identified. The salt glaze on this sherd is less shiny and vitreous than that on the Grosvenor bottle and may indicate an early-nineteenth-century date (Munsey 1970:135).

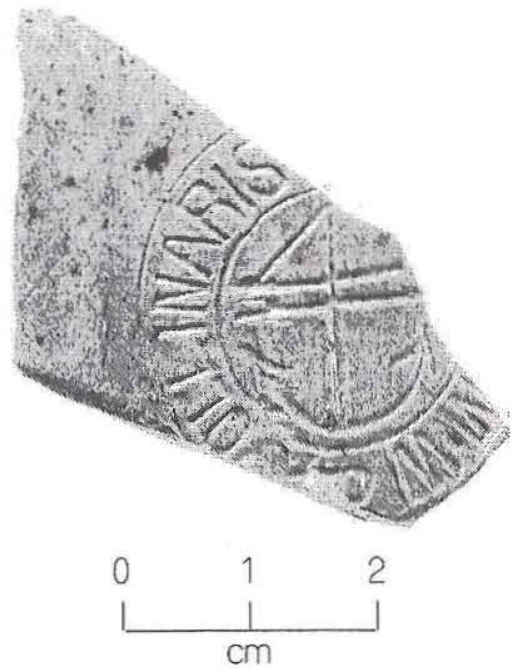

Figure 57. Impressed stoneware maker's mark.

\section{WHITEWARE DECORATION TYPES}

Temporally diagnostic ceramics are discussed by decoration type. Ware types also are noted.

Molded

Two of the three sherds with molded decoration are classified as white granite because of their molded decoration; one of these also has the semivitreous paste typical of white granite. One is a green-tinted whiteware of unknown type. Molding occurring in combination with color decoration is discussed under the particular decoration type.

A blue-tinted semivitreous whiteware (lid?) body sherd has a molded high-relief foliate design consisting of opposing serrated leaves on one branch and trefoil leaves on another branch (Figure 58a). A whiteware lid (?) sherd with scalloped rim has a molded high-relief ridge consisting of

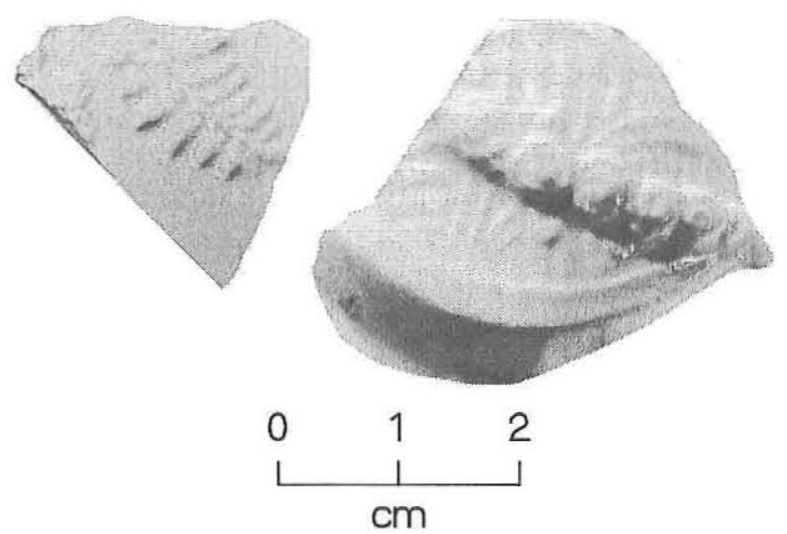

Figure 58. Molded whitewares. (a) Semivitreous whiteware with molded foliate pattern; $(b)$ whiteware with molded rose pattern.

adjacent roses with leaves above a swag background (Figure $58 b$ ). Neither of these patterns was identified in Wetherbee (1985). An additional vessel with molded decoration is a ribbed base from a green-tinted whiteware, possibly a custard cup.

White granite or ironstone made in England and the United States was popular from 1840 to 1870 (Wetherbee 1985:6). White granite dating from the $1840 \mathrm{~s}-1860 \mathrm{~s}$ almost always was vitrified and was produced in molded geometric or naturalistic patterns, but, by the 1870 s, much of it was fired below the temperature necessary to produce a vitrified ware and was produced in plain round or rectangular shapes. Often a blue tint was added to the body or to the glaze (Miller 1993:4-6). Majewski and O'Brien (1987:154-155) note that completely undecorated white granite began to rise in popularity during the $1870 \mathrm{~s}-1880 \mathrm{~s}$. After about 1890 , Staffordshire factories drastically cut production of the traditional heavy white granite ware except for toilet sets and hotel ware. The elaborate molding of the Fort McKavett sherds indicates a probable English origin and 1840 s -1860 s period of production (Majewski and O'Brien 1987:154155).

Edged

Seven sherds from five or six blue shell-edged plates with unscalloped rims are both cobalt colored and molded to create the shell-edged effect. Production of shell edge continued into the 1890 s and possibly later (Miller 1991:6), and lightly 
molded plates with unscalloped rims occur on Texas sites dating to the last quarter of the nineteenth century. The light curved-line molding on these plates probably indicates production in the second half of the nineteenth century unless all of these plates happened to be made in worn molds (Majewski and O'Brien 1987:148). Hunter and Miller (1994:434-435) date tablewares in which the shell edging is created only by the painting to ca. 1860-1890. Unscalloped rims first appear on the East Coast in 1830, and plates with unscalloped rims and impressed molding date 1830-1860. These examples probably postdate the Civil War.

\section{Annular}

A dark brown banded annular whiteware (bowl?) sherd with bright blue ground and a whiteware body sherd with possible annular decoration were found. Most annular-decorated nonvitreous whiteware was produced in England from about 1790 through the early twentieth century as an inexpensive ware for both local use and export. The banded sherd's bright blue field and the possibly annular white-swirled decoration on a blue and green field resemble the twentieth-century bold palette rather than the nineteenth-century earthentones palette (Majewski and O'Brien 1987:162163; Price 1979:18).

\section{Sponge Stamped}

Two sponge-stamped whiteware sherds probably are from the same saucer. The pattern consists of cobalt blue edging (similar to shell edging) along the unbanded rim and cobalt leaves below the flower, which consists of a cluster of small brown circles and small green leaves (Figure 59).

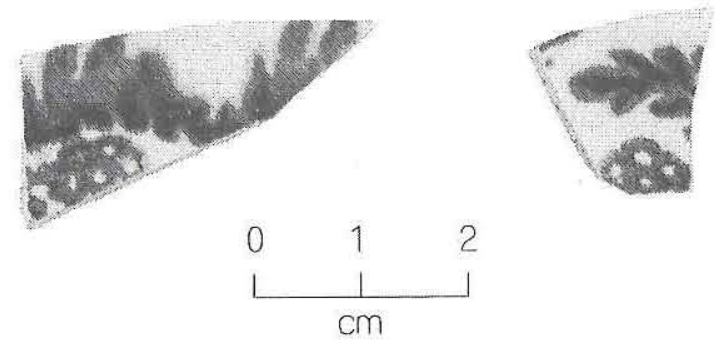

Figure 59. Sponge-stamped whiteware saucer.

Cut sponge decoration was developed in 1845 and exported from Great Britain, and particularly
Scotland, to Canada between the 1840 s and 1920 (Majewski and O'Brien 1987:161-162). Price index values for sponged wares are available for the period from 1848 to 1871 (Miller 1991:6).

\section{Sponge Spattered}

Blue spatter decoration similar to open sponge in its large interstitial openings occurs on an earlynineteenth-century whiteware cup base fragment. The decoration is an arrangement of coarse, irregularly shaped dots with the pattern of curved lines perhaps indicating rhythmic use of the spattering implement (Robacker and Robacker 1978:34). A white earthenware sherd with blue, probably sponge spatter but possibly flow blue, decoration is too small for further identification.

Spatter-decorated ceramics were produced in great quantities by British potteries throughout the nineteenth century, primarily for export, and in the United States after about 1850. Spatter decoration appeared on a wide range of tablewares and tea services (Majewski and O'Brien 1987:161). Sponge wares without painting are not common before the late $1840 \mathrm{~s}$ when cut sponges were introduced (Miller 1991:6).

\section{Open Sponge}

Blue open-sponge decoration occurs on two thick white earthenware body sherds, possibly from crocks or bowls. This decoration type, also called kitchen or cottage spatter (Robacker and Robacker 1978:118-121) or mottled or spongeware (Ketchum 1987:10-11), refers to designs with large interstitial openings that look as if they were applied by a sponge or chamois. This decoration was applied to a variety of kitchenware and tableware forms by British and American potteries from 1860 to 1935 (Majewski and O'Brien 1987:162). Ketchum (1987:10) notes that this decoration type occurs on bodies ranging from stoneware to yellowware to an inexpensive and rather coarse white earthenware. Open sponge was relatively common on whiteware from 1850 to 1870 and on yellowware and stoneware from 1880 to 1940 (Ketchum 1987:11).

Painted

Two underglaze hand-painted whiteware sherds are possibly from a single cup. The rim 
sherd is unscalloped and decorated with a dark red interior rim band and a tiny fragment of light green on the outside. The decoration is too fragmentary to identify further. The body sherd has a dark red thickline floral design fragment.

Colors introduced in painted wares in the 1830 s included red and light shades of blue and green. The thickline style is characterized by stylized floral motifs in broad brush strokes that cover most of a vessel's surface. Thickline decoration usually occurred on teawares. The peak popularity period for the thickline style was 1840-1860 (Majewski and O'Brien 1987:157-159). Large painted floral polychrome motifs returned to popularity during the $1870 \mathrm{~s}$, and these often are found on tablewares and teawares (Miller 1991:8).

\section{Enameled}

Three sherds from a polychrome enameled semivitreous whiteware hollowware vessel, possibly a teapot, were found. The fragments are decorated in an unknown style featuring black lines, some feathered, and olive green, brown, and yellow, with the olive green applied in a splotchy fashion similar to a fuzzy dendritic mocha or moss agate effect.

A polychrome enameled vitreous whiteware hollowware sherd is decorated in a probable floral pattern that has partially worn away. Colors are dark red, dark green, and orange.

A polychrome enameled vitreous whiteware cup (?) sherd is decorated in a floral design. Colors are green, red, and fineline black, but the pattern is not identifiable.

Overglaze china painting was popular from 1880 to 1905 . Floral designs probably were the most popular motifs, but border designs also were common (Majewski and O'Brien 1987:160).

Three copper enameled whiteware sherds are from a handled cup rim and the base from this cup or a saucer, both decorated in the original tea leaf pattern. The mark on the base is discussed in the Marks section. This pattern, originally known as Lustre Band with Sprig or Lustre Spray, was introduced in the $1850 \mathrm{~s}$ and was used in the 1870 s-1890s on many white granite body forms, peaking in popularity between 1880 and 1900 (Majewski and O'Brien 1987:160; Wetherbee
1985:149-155).

A polychrome luster-decorated vitreous whiteware rim sherd is from an unknown vessel, possibly a small-mouthed jar or vase with a black band at the shoulder. Luster colors are pink and aqua (mother-of-pearl), possibly forming a wavy resist decoration pattern. Shading and stenciling in luster colors were used in the nineteenth and twentieth centuries (Majewski and O'Brien 1987: $140,160,164)$.

A porcelain cup base with pink luster has fluting spiraling up the exterior of the cup (Figure 60 ). White earthenware fluted teas are listed in Staffordshire potters' price-fixing lists for 1846, 1853 , and 1859 and appear to have been most popular in the early nineteenth century (Miller 1991:16). This porcelain version would have been a relatively expensive teaware compared to others found at the fort and also may date to the antebellum military occupation.

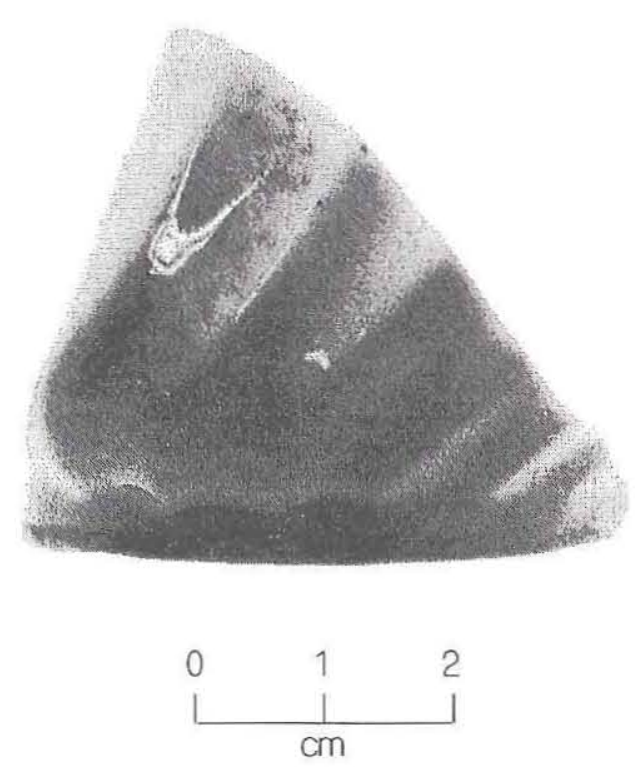

Figure 60. Fluted porcelain cup base with pink luster.

A molded whiteware plate rim sherd with silver luster accenting and rim band has a lowrelief scroll pattern. By 1880 relief decoration tended to be delicate, with floral and 'abstract motifs on thin semivitreous to vitreous wares possibly influenced by the art nouveau movement (1880-1905). Molded motifs with hand-painted accents gilded in metallic luster colors occur in the second half of the nineteenth century (Majewski 
and O'Brien 1987:152-153, 155, 164).

Flow Printed

Nineteen sherds are decorated with flown transfer printing, all in blue. Flow printing dates from 1840 to 1910 (e.g., Williams 1981:ii), but the flow-printed vessels from the late nineteenth and early twentieth centuries are relatively easily distinguishable by their molded and gilded rims. Unlike many of the transfer-printed sherds, which appeared to derive from vessels with sprig-type pattern decoration, many of the flow blue nonbody sherds appeared to derive from vessels with repeated string motifs decorating the rim and base of the vessels, similar to early-nineteenth-century transfer printing.

Most of the flow blue sherds are small and the patterns unidentifiable. The only two rim sherds are two unscalloped whiteware platter sherds. These sherds, almost certainly from the same platter, are decorated in an open floral and scroll rim pattern (Figure 61a) that could not be identified in Gaston $(1983,1994)$, Snyder $(1992,1994)$, or Williams $(1981,1986,1988)$.

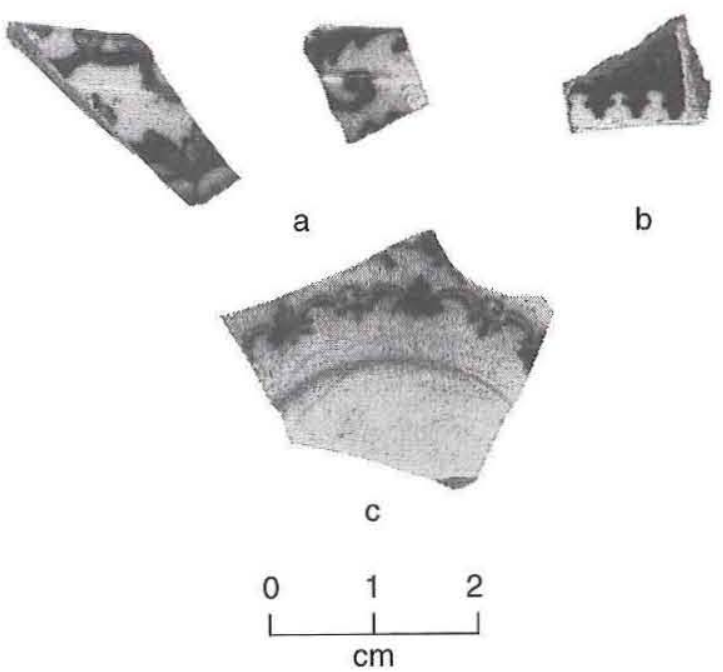

Figure 61. Flow blue ceramics. (a) Platter rims; $(b)$ plate or platter well wreath pattern; $(c)$ saucer well wreath pattern.

Another potentially identifiable pattern is a body sherd from a whiteware plate or platter. The spearpoint well wreath pattern on this sherd (Figure $61 b$ ) resembles the Vincennes pattern (Williams 1986:21) made by John Alcock from
1853 to 1861 (Godden 1964:27, Mark 67), but the sherd is too small and Williams's (1986:21) photograph is too blurred to make a definite identification.

Another potentially identifiable pattern is a base sherd from a saucer. The scroll-like well wreath pattern (Figure 61c) on this sherd was not identified in Gaston $(1983,1994)$, Snyder (1992, 1994), or Williams (1981, 1986, 1988).

Two whiteware sherds, possibly from the base of a saucer, are decorated with a flow blue print with enameling. The pattern is floral or scenic, and the yellow and green enameling was applied on flowers and trees. The pattern is unidentified.

\section{Transfer Printed}

Twenty-four sherds are decorated with transfer printing. Underglaze transfer printing on whiteware was common in the second and third quarters of the nineteenth century. Most of the transfer patterns are contemporary with or postdate the flow blue patterns.

Two whiteware sherds, one from an unscalloped platter (possibly octagonal) rim and one from a probable plate body sherd, are decorated in blue with the Priory transfer pattern. This version of the pattern was made by John Alcock from 1853 to 1861 (Williams 1978:380-381) and is characterized by grape leaves and clusters on a basketweave type ground on the brim of the tableware (Figure 62a).

None of the 15 other possibly identifiable underglaze transfer patterns could be matched with published references (Coysh and Henrywood 1982, 1989; Lockett 1972; Lockett and Godden 1989; Moore 1903; Williams 1978; Williams and Weber 1986; Wood and Wood 1975). Some of these motifs are highly diagnostic and identifiable (Figure 62b). These references include some patterns dating to the final quarter of the nineteenth century (for example, Coysh and Henrywood's [1982, 1989] dictionary covers the 1780 1880 period) but focus on the first half of the nineteenth century (e.g., Romantic tranșfers produced from 1835 to 1850 [Williams 1978:21]), before Fort McKavett was established in 1853 .

Most of the fort patterns consist of floral and geometric motifs similar to monochrome examples in Silber \& Fleming's (London) ca. 1881 catalog of English and foreign Victorian glass and china. 

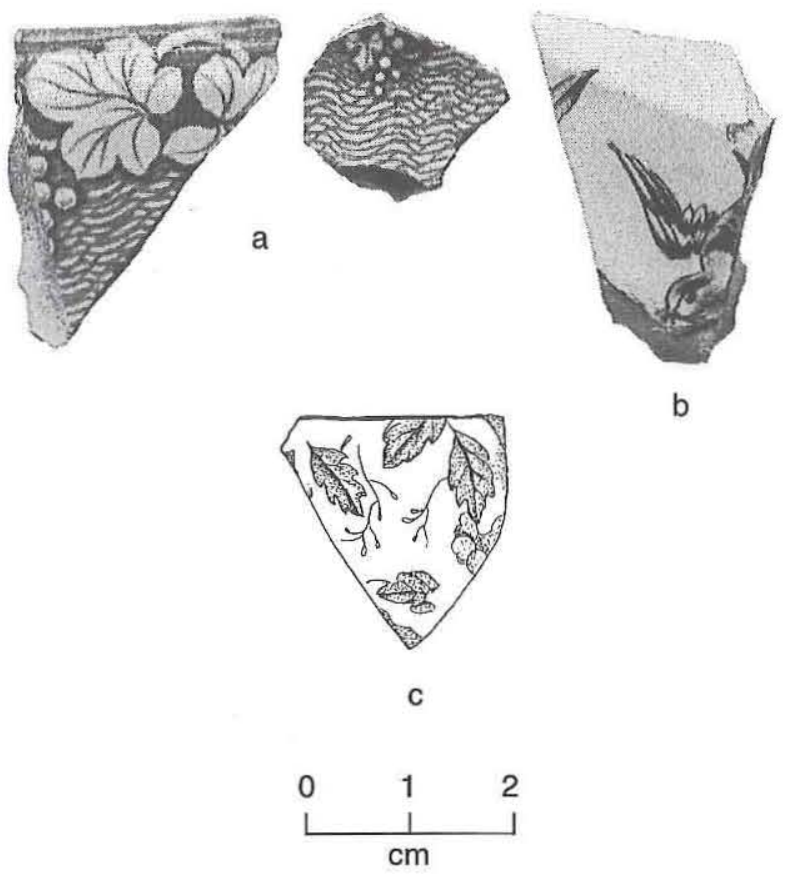

b

Figure 62. Transfer-printed whitewares. (a) Blue
Priory transfer pattern on a platter rim and a plate body; (b) black bird motif on a platter body; (c) brown cup rim with foliate motifs.

The floral and geometric motifs tend to cover less of the vessel's surface than does the undecorated ground (Figure 62c), which is characteristic of a sprig-type pattern. The designs generally tend to become less complex and more open through time with larger portions of the vessel being left undecorated. By the last half of the century, the design occupied less than half of the vessel (Price 1979:19).

Decal

Six sherds are decorated with monochrome decals. Four of these have been hand tinted to produce a polychrome floral design. None of the patterns was identified.

Two whiteware sherds are decorated with probably the same light green floral pattern. One vessel is a possible saucer with a scalloped rim, and the other is an unknown body sherd from a different vessel. Two whiteware sherds, one an unscalloped saucer rim and the other a body sherd probably from a plate, are decorated with a brown decal tinted with pink. Two vitreous whiteware sherds, probably from a single vessel (saucer?), are decorated with dark brown decals, and the leaves and flowers in this floral pattern are tinted with blue and brown in broad, washlike strokes.

Vessels with monochrome decals are older than those with polychrome decals. By 1885 , monochrome outline decals were used as the basis for hand-painted fill-in. Decal-decorated ceramics were used on semivitreous British ceramics and porcelain before 1900. Decal outlines often were used as the base for hand-painted finishing. The execution of the hand-painted motifs ranges from quite sloppy, as in these examples, to extremely carefully done (Majewski and O'Brien 1987:147, $160)$.

Yellowware

A yellow earthenware body sherd with a mottled brown decoration (variously termed flint enamel, Rockingham-type, or tortoise-shell glaze) was recovered. Brown flint enamel was made in Great Britain throughout the nineteenth century and in New Jersey, Pennsylvania, Maryland, and Vermont by 1830 but did not reach important levels of production until midcentury. The brown color at Bennington, Vermont, was spattered on by dipping a paddle into a vat of glaze, striking the paddle on the edge of the vat, and letting spatter drip onto the vessel being rotated on a wheel (Robacker and Robacker 1978:66, 72-73).

\section{Bottle Glass}

Fifty bottles or bottle glass fragments potentially dating to the military occupation were analyzed. Since so many of the specimens are fragmentary, six relatively complete bottles from the 1977 excavations in the Officers' Quarters 3 pit latrine were included in the analysis for comparative purposes.

Bottle types are wine, pickle/condiment, umbrella ink, and probably beer, stout, ale, bitters, whiskey, brandy, and other intoxicants (Table 7). Attributes are described using Jones and Sullivan (1989), Switzer (1974), and Wilson (1981). The temporally diagnostic glass assemblage at Fort McKavett includes types similar to those in the assemblage from the steamer Bertrand, which sank in 1865 (Switzer 1974), and from Forts Laramie and Union, occupied 1849-1890 and 1851-1891, respectively (Wilson 1981). 
Bottle types were difficult to distinguish definitely based on either finish and color or base and color since similar finishes and/or bases often were used for wine, whiskey, brandy, bitters, beer, stout, and ale bottles. With one exception, the olive green one-part wine or bitters finishes are present on long necks more consistent with the cylindrical brandy or wine bottle form illustrated in Wilson (1981:Figures 72, 76, 77) than with the short-necked square-based bitters forms illustrated in Switzer (1974:Figures 37, 40, 43, 46, 48-50, 52). Similarly, brown one-part finishes (Figure 63) were classified as beer or bitters although only one of these finishes occurs on a possibly short necked bitters form. The two-part olive green finishes with straight or rounded upper and downtooled lower string rim elements are similar to Switzer's (1974:Figures 16, 19, 20) ale bottle form, which occurred on the Bertrand only in brown glass. The olive green upper bottle half is probably a wine bottle although the neck is brandy shaped.

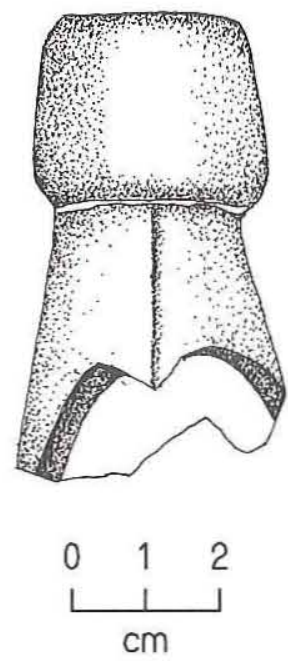

Figure 63. Brown beer/bitters bottle with one-part down-tooled finish and two-piece molded neck.

Olive green bases with conical or U-shaped profiles or with large mamelons are classified as wine rather than champagne, since no champagne finishes are present in the assemblage (Figure 64). Olive green bases with dome-shaped profiles are classified as wine or whiskey forms, and those with conical bases and pontil marks are classified as wine bottles.

Identifiable marks are " $\mathrm{B} \mathrm{G} \mathrm{Co/4"} \mathrm{on} \mathrm{a} \mathrm{brown}$ base and "C W" on an olive green wine bottle

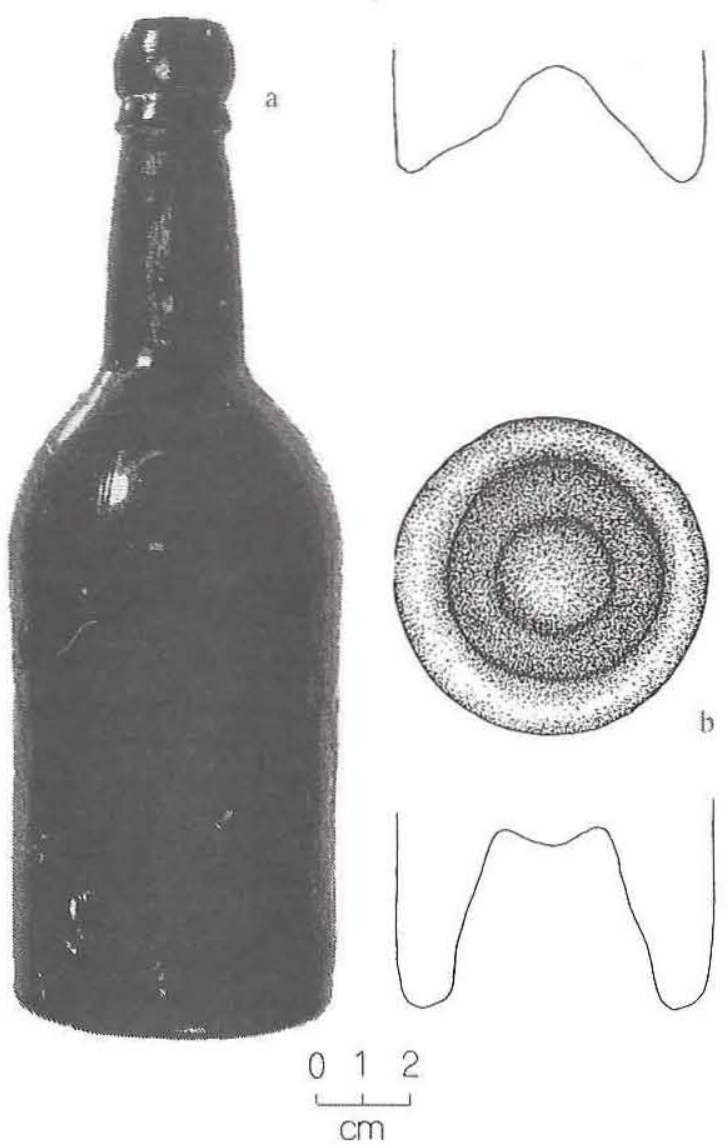

Figure 64. Olive green wine bottles. (a) Three-piece molded body, two-part finish, and conical base profile; (b) dip-molded base with U-shaped profile and large mamelon.

base. The former mark is attributed to the Burlington Glass Works of Hamilton, Ontario, from 1877 to 1909 (Toulouse 1971:85-86). The latter mark is unidentified.

Temporally diagnostic attributes include glass color, manufacturing, and distribution variables. Many of the technology changes, such as the end of empontilling and the beginnings of turn molding and the pasteurization of beer, occurred shortly after the end of the Civil War at about 1870 , so that these attributes can signal glass possibly dating to the last 10-15 years of military occupation and can serve to distinguish the pre- and post-Civil War occupations in a general way.

Olive green or opaque "black" glass was used primarily for alcoholic beverages such as wine, stout, and ale prior to ca. 1870. Brown glass was used widely after ca. 1860 , including for alcoholic beverages such as beer and whiskey. Aqua glass, 
TABLE 7

BOTTLE GLASS

\begin{tabular}{|c|c|}
\hline Type & Description \\
\hline $\begin{array}{l}\text { Olive Green Finishes } \\
\text { wine/brandy } \\
\text { wine/bitters } \\
\text { wine/bitters } \\
\text { unknown } \\
\text { wine } \\
\text { beer/stout? } \\
\text { beer/stout? } \\
\text { beer/stout? } \\
\text { beer/brandy? } \\
\text { wine/beer } \\
\text { wine/beer } \\
\text { wine/beer } \\
\text { unknown } \\
\text { unknown } \\
\text { unknown }\end{array}$ & $\begin{array}{l}\text { upper bottle half with two-part down-tooled finish, horizontal seam below shoulder, } \\
\text { turn-molded } \\
\text { one-part down-tooled or oil type } \\
\text { one-part straight } \\
\text { two-part unknown } \\
\text { two-part down-tooled } \\
\text { two-part, straight upper, down-tooled lower } \\
\text { two-part, straight upper, down-tooled lower, fire-polished lip } \\
\text { two-part, straight upper, down-tooled lower, fire-polished lip (two fragments) } \\
\text { two-part, rounded upper, V-shaped lower } \\
\text { two-part, rounded upper, down-tooled lower, free-blown neck/shoulder } \\
\text { two-part, rounded upper, down-tooled lower, wire for cork } \\
\text { two-part, rounded upper, down-tooled lower, fire-polished lip, free-blown neck } \\
\text { fragmentary two-part } \\
\text { down-tooled lower fragment } \\
\text { fragment }\end{array}$ \\
\hline $\begin{array}{l}\text { Olive Green Bases } \\
\text { wine/whiskey } \\
\text { wine } \\
\text { wine/whiskey } \\
\text { wine? } \\
\text { wine? } \\
\text { wine } \\
\text { wine } \\
\text { wine } \\
\text { wine } \\
\text { wine/whiskey } \\
\text { wine/whiskey } \\
\text { wine? } \\
\text { wine? } \\
\text { wine? } \\
\text { wine } \\
\text { wine } \\
\text { wine } \\
\text { wine }\end{array}$ & $\begin{array}{l}\text { turn-molded base with mamelon and dome-shaped profile } \\
\text { dip-molded base with U-shaped profile and large mamelon } \\
\text { fragment with ring-shaped base part and dome-shaped profile } \\
\text { concave fragment with ring-shaped base part and . . "LFF" ... mark } \\
\text { fragment with ring-shaped base part, dome-shaped profile, four mamelons, marked } \\
\text { probably "H" } \\
\text { fragment with ring-shaped base part, slightly conical shaped profile, small mamelon, } \\
\text { marked "C W" } \\
\text { conical-shaped profile with sand pontil mark } \\
\text { conical-shaped profile, probably empontilled } \\
\text { conical-shaped profile, probably empontilled } \\
\text { dome-shaped profile } \\
\text { shallow concave profile } \\
\text { two fragments, possibly from same bottle } \\
\text { fragment } \\
\text { fragment } \\
\text { fragment with U-shaped profile and large mamelon } \\
\text { pushup fragment with large mamelon } \\
\text { pushup fragment with large mamelon } \\
\text { pushup fragment with large mamelon }\end{array}$ \\
\hline $\begin{array}{l}\text { Brown Finishes } \\
\text { beer/bitter } \\
\text { beer/bitters } \\
\text { beer/bitters } \\
\text { beer/bitters } \\
\text { beer/bitters } \\
\text { alcohol } \\
\text { unknown } \\
\text { alcohol } \\
\text { beer/ale }\end{array}$ & $\begin{array}{l}\text { one-part down-tooled or oil type, two-piece molded neck } \\
\text { one-part down-tooled or oil type } \\
\text { one-part down-tooled or oil type with rust from wire tie-down for cork } \\
\text { one-part down-tooled or oil type } \\
\text { one-part down-tooled or oil type, no neck seams } \\
\text { straight brandy type, two-piece molded neck } \\
\text { brandy type? one bead with deep groove } \\
\text { two-part, straight upper, down-tooled lower, two-piece molded neck } \\
\text { two-part, down-tooled upper, V-shaped lower }\end{array}$ \\
\hline
\end{tabular}




\begin{tabular}{|c|c|}
\hline Type & Description \\
\hline $\begin{array}{l}\text { Brown Bases } \\
\text { bitters? } \\
\text { beer? }\end{array}$ & $\begin{array}{l}\text { fragment of square base with rounded corners } \\
\text { two-piece molded body and separate cup mold base with flat indentation, } \\
\text { marked "B G Co/4" }\end{array}$ \\
\hline $\begin{array}{l}\text { Aqua Finishes } \\
\text { umbrella ink (complete) } \\
\text { umbrella ink (complete) } \\
\text { umbrella ink } \\
\text { pickle/condiment } \\
\text { beer? ketchup? }\end{array}$ & $\begin{array}{l}\text { two-piece mold, single bead finish, flat octagonal base } \\
\text { two-piece mold, fire-polished folded-out finish, octagonal base with glass pontil mark } \\
\text { finish with patent lip } \\
\text { finish with folded-out lip } \\
\text { two-part, straight upper, rounded lower, two-piece molded neck, cork and } \\
\text { metal cork protector with wire }\end{array}$ \\
\hline
\end{tabular}

on the other hand, has been used widely since the introduction of glass bottles and is not temporally diagnostic (Fike 1987:13).

All finishes for which manufacture could be determined were made with finish-forming tools with the following exceptions: one of the umbrella inks and the pickle/condiment bottle have handmade folded-out lips. Finish-forming tools were used from the 1820 s to 1920 s (Jones and Sullivan 1989:43).

Two wine bottles have sand pontil marks, one ink bottle has a glass-tipped pontil mark (Figure 65 ), and two wine bottles probably are empontilled. Ca. 1870 is used as a general end date for pontil marks. All other bases presumably were held in snap cases while their finishes were applied. Handmade glassware without a pontil mark and with evidence of use of a finish-forming tool date after ca. 1850 (Jones and Sullivan 1989:45, 47).

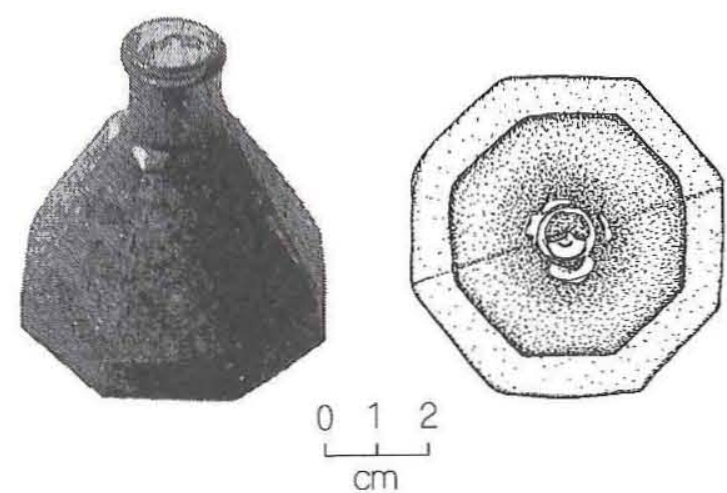

Figure 65. Aqua umbrella ink bottle with folded-out finish and octagonal base with glass-tipped pontil mark.
Dip molding probably was used to manufacture most of the olive green wine bottles in the assemblage in combination with free-blown necks and finish-forming tools. In the United States, this mold type declined in use during the second half of the nineteenth century (Jones and Sullivan 1989:26).

Molds with separate base parts, such as the ring-shaped base parts occurring on four of the olive green wine or wine/whiskey base fragments, were a key element in the Ricketts 1821 patent and still were available in the 1880 s in non-olive green glass (Whitall, Tatum \& Co. 1971:9).

Two olive green wine/brandy and wine/ whiskey bottles were turn molded (Figure 66). Turn molding was not observable on some bottles because of heavy patination. Turn-molded champagne bottles were recovered from the steamer Bertrand, sunk in 1865, and turn-molded bottles manufactured from the 1870 s through World War I include hock wine, brandy, and other liquor bottles (Jones and Sullivan 1989:31).

Lager beer was not shipped long distances until after the development of pasteurization in the 1870 s, so that the numerous olive green, brown, and aqua possible beer bottles postdate 1873. The aqua possible beer or ketchup finish (Figure 67) has an intact cork and metal cork protector and the stain from the wire closure below the finish. Another factor related to liquor bottle frequencies at enlisted men's barracks was the 1881 presidential order prohibiting the sale of hard liquor by post traders to enlisted men on army posts, an order which confined soldiers' drinking to beer and 


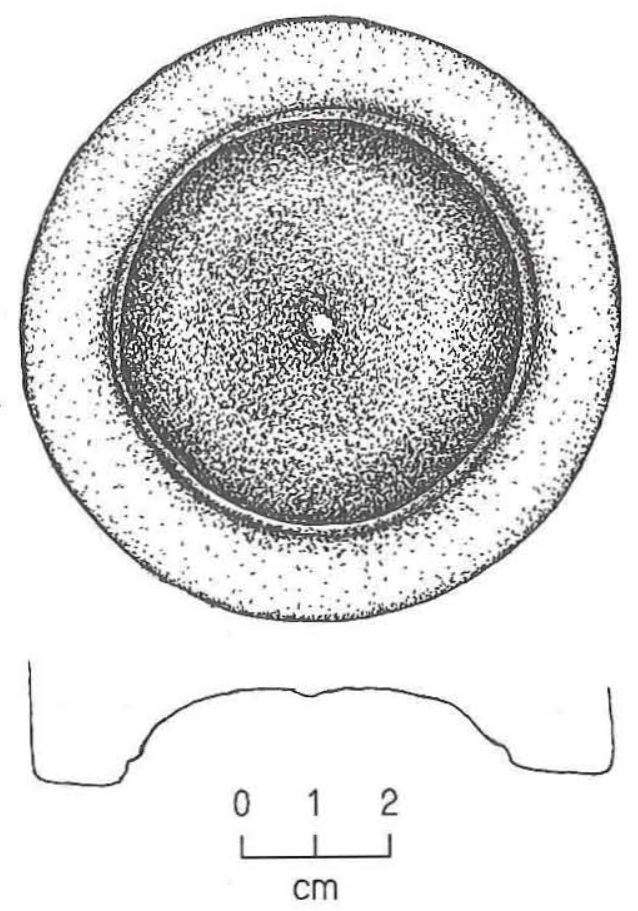

Figure 66. Olive green wine/whiskey bottle turnmolded base with mamelon and dome-shaped base profile.

wine (Wilson 1981:1-2) and would have affected only the last 2 years of the Fort McKavett military occupation.

The consumption of ink at a nineteenthcentury army post was enormous (Wilson 1981:95). An aqua ink bottle (Wilson 1981:Figure 379) with an octagonal base and 2-ounce capacity from Fort Union similar except in finish to the Fort McKavett examples dates 1870-1890; this example, because of its post- 1870 date, presumably has no pontil mark, as is true for the McKavett example with the single bead finish (Wilson 1981:95).

The folded-out lips found on the aqua pickle/condiment and ink bottles may date to the same period as the folded-in lip, in use from the early 1800 s but uncommon by the last quarter of the century (Jones and Sullivan 1989:80-81).

\section{Cork Protector}

A ferrous metal cork protector from Officers' Quarters 6 was used to protect a bottle cork from being

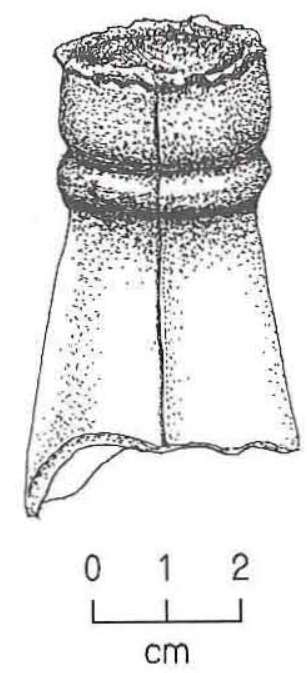

Figure 67. Aqua possible beer or ketchup bottle with two-part finish, two-piece molded neck, and metal cork protector and wire closure.

cut by the wire used to tie it down. The cork protector has rolled edges and a concave center to maximize contact with the bottle finish and bore. The cork protector measures $15 / 16$ inch in diameter and $3 / 16$ inch deep.

\section{Table Glass}

Six pressed glass fragments (two aqua and four colorless) were analyzed (Table 8). None of the patterns was identified. The colorless glass fluoresced ice blue under shortwave ultraviolet light, indicating the presence of lead.

Lead glass was used in the manufacture of pressed glassware but was replaced to a large extent by the less expensive soda-lime glass developed by Leighton in the 1860 s, although the former is still the preferred glass for fine tableware

\section{TABLE 8}

TABLE GLASS

\begin{tabular}{|l|l|}
\hline Aqua & Colorless Leaded \\
\hline Circular (sugar bowl?) lid & Tumbler base fragment, 8 or 10 sides, \\
fragment with molded & inner dish-shaped concavity \\
naturalistic design & Diamond pattern fragment \\
forming handle & Goblet or vase (?) fragment with \\
Fragment with multiple & pattern-molded tendril design \\
sunburst pattern & Pattern-molded fragment with tendril \\
& design with chain link motif \\
\hline
\end{tabular}


Chapter 5: Artifacts

(Jones and Sullivan 1989:12). These lead glass fragments could represent either trash from the pre-Civil War occupation or remnants of fine tableware from a later occupation.

\section{Clothing}

A button similar to military buttons in manufacture and probably dating to the post-Civil War military occupation is a Sanders's type with the front flattened and measures $22.8 \mathrm{~mm}$ in diameter. The front is decorated with a raised mark of "S.O. \& CO./N.Y." framing a locomotive against a horizontal lined background (Figure 68). The backmark is impressed and mostly illegible. This button may have been worn by a railroad employee.

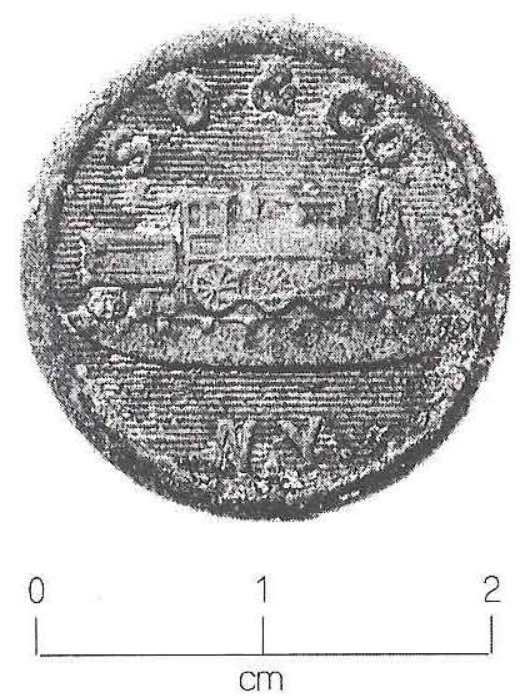

Figure 68. Button with a locomotive design.

Two hooks from a hook-and-eye clothing closure were found in Officers' Quarters 6. The larger hook may relate to the military occupation. This specimen is .52 inch long and made of brass wire .03 inch thick. It may have been used on the 1872 folding campaign hat fitted with hooks and eyes so that it could be worn extended to shed sun or rain or fastened up. Another possible use was adding a hook and eye under the tassel of cavalry soldiers' 1872 dress helmets to facilitate removal during formal social events (McChristian 1995: 45-46, 147). The other hook from a hook and eye, by comparison, is .46 inch long and made of brass wire .01 inch thick. This hook also could have been used on a military hat but more likely was used on other clothing.

\section{Tobacco-Related Artifacts}

\section{Tobacco Pipes}

Fifteen tobacco pipe fragments consist of three made of white ball clay and the remainder of clays firing light brown, reddish brown, red, grayish brown, or brown, depending on placement in the kiln. Attributes of the pipes are summarized in Table 9. All decoration is molded. The degree of decoration is variable, and a reddish brown stem fragment with foliate, floral, and scroll motifs is the most elaborately decorated specimen. Two light brown bowl rim fragments from Officers' Quarters 4, Room 2, with dotted bead decoration may be parts of the same pipe, and a similar but not identical pattern occurs on a light brown bowl rim fragment from Officers' Quarters 6. This dotted bead pattern resembles a pattern from Fanthorp Inn (Ing and Hart 1987:Plate 19A).

Only two specimens are marked. The "1" or "L" on the white pipe stem fragment cannot be attributed definitely to a maker. This symbol has been reported on McDougall pipes from Fort Bowie (Herskovitz 1978:117), occupied by the military from 1862 to 1894 ; on a McDougall pipe from Fort Fetterman, Wyoming (Wilson 1981:29), occupied by the military from 1867 to 1882 ; and on a TD pipe (Wilson 1981:40) from Fort Sanders, Wyoming, occupied by the military from 1866 to 1882. The ... "CATL" . . mark could not be attributed to a maker.

Since the marks on these pipes are unknown and the patterns are relatively simple or unidentified, they cannot be dated securely. During the second half of the nineteenth century, the most popular clay pipes were the simple styles. By the turn of the century, the American smoking pipe industry had risen to heights of quality and production equal to those of the combined efforts of the European factories. One of the companies producing red and brown elbow pipes was the Pamplin Smoking Pipe and Manufacturing Company, Inc., of Virginia, beginning between 1885 and 1890 and continuing at least through 1941 (Wilson 1981:8, 10, 12). Another American company, the American Clay Pipe Works, Inc., of New York, was in business from 1905 until 1967 (American Clay Pipe Works, ca. 1915-1920). 


\begin{tabular}{|c|c|c|c|}
\hline \multicolumn{4}{|c|}{$\begin{array}{c}\text { TABLE } 9 \\
\text { TOBACCO PIPES }\end{array}$} \\
\hline Portion & Finish & Decoration & Mark \\
\hline $\begin{array}{l}\text { White } \\
\text { stem/heel fragment } \\
\text { bowl fragment } \\
\text { stem fragment }\end{array}$ & $\begin{array}{l}\text { burnished } \\
\text { burnished } \\
\text { plain }\end{array}$ & $\begin{array}{l}\text { on spur (unknown) } \\
\text { none } \\
\text { none }\end{array}$ & $\begin{array}{l}\text { " } 1 \text { " or " } L " \text { on stem } \\
\text { none } \\
\text { none }\end{array}$ \\
\hline $\begin{array}{l}\text { Colored } \\
\text { bowl rim fragment } \\
\text { bowl rim fragment } \\
\text { bowl rim fragment } \\
\text { bowl rim fragment } \\
\text { bowl rim fragment } \\
\text { bowl fragment } \\
\text { bowl fragment } \\
\text { stem fragment } \\
\text { stem fragment } \\
\text { stem/bowl fragment } \\
\text { stem fragment } \\
\text { stem fragment }\end{array}$ & $\begin{array}{l}\text { glazed } \\
\text { glazed } \\
\text { glazed } \\
\text { glazed } \\
\text { glazed } \\
\text { plain } \\
\text { burnished } \\
\text { glazed } \\
\text { plain } \\
\text { glazed } \\
\text { glazed } \\
\text { plain }\end{array}$ & $\begin{array}{l}\text { raised dots in band } \\
\text { dotted beads } \\
\text { dotted beads } \\
\text { dotted beads } \\
\text { unknown } \\
\text { ribbed } \\
\text { none } \\
\text { foliate/floral/scroll } \\
\text { ribbed and ring around mouthpiece } \\
\text { ring around mouthpiece } \\
\text { fluted and large ring around mouthpiece } \\
\text { ring around mouthpiece }\end{array}$ & $\begin{array}{l}\text { none } \\
\text { none } \\
\text { none } \\
\text { none } \\
\text { none } \\
\text { none } \\
\text { raised ... "CATL" } \\
\ldots \text {... on bowl } \\
\text { none } \\
\text { none } \\
\text { none } \\
\text { none } \\
\text { none }\end{array}$ \\
\hline
\end{tabular}

\section{Tobacco Tags}

Two thin ferrous metal tobacco tags possibly dating to the military occupation are corroded, and no brand name information remains on the front surface. One is an oval $7 / 8$ inch long by $5 / 8$ inch wide with prongs on opposing sides for pressing into the tobacco plug. The other is a parallelogram approximately $1 \frac{1 / 4}{4}$ inches long by $5 / 16$ inch wide with prongs on either end.

The P. Lorillard Company, one of the first of the large-scale chewing tobacco plug producers, began to mark its plugs with pronged metal tags in 1870 to protect its brand name. These metallic quality indicators quickly became popular (Sudderth 1992:35-36). Some 12,000 chewing tobacco brands were present in the 1880 s, and these included duplicate names until the tags were covered by registered trademark laws in 1885 . Tobacco tags began to be replaced with cellophane wrappers in the 1930s (Peterson 1988:105).

\section{Coins and Tokens}

Two dimes, two nickels, and three tokens were found. Both dimes are the seated Liberty type, made from 1837 to 1891 . The 1853 dime from
Room 3 of Officers' Quarters 4 is the third variety with stars on the obverse, drapery from the elbow, upright shield, and arrows at the date, made from 1853 to 1855 . This dime has an $\mathrm{O}$ mint mark for the New Orleans mint, and 1.1 million of these dimes were made that year (Yeoman 1975: 104-105). The 1878 dime from Officers' Quarters 11 is the fourth variety with the "UNITED STATES OF AMERICA" legend on the obverse and no arrows at the date, made from 1875 to 1891 (Yeoman 1975:107). No mint mark is present.

Both nickels are the shield type and came from Officers' Quarters 6. One is the variety with rays between the stars on the reverse and is dated 1867 , the last year in which rays were included. The shift to no rays occurred that year, indicating that this coin was minted in the early part of 1867 . Two million of these coins with rays were produced (Yeoman 1975:89). There is no mint mark, but all were coined at the Philadelphia mint. The other nickel is an 1869 variety without rays between the stars on the reverse. There were 16.4 million of these coins produced, and all also were coined at the Philadelphia mint (Yeoman 1975: 89-90).

The description of tokens follows the standard for Texas trade tokens in Fowler et al. (1973). 
None of the tokens is military related. The obverse face of a trade token from Officers' Quarters 6 is decorated with a raised Liberty head with 13 stars and is dated 1868. This round token is $38 \mathrm{~mm}$ in diameter and of sheet copper or brass. As the reverse face is not present, the issuer and purpose of this token is unknown.

A uniface token is impressed "IRONCLAD/ SALOON/GOOD FOR/ONE DRINK." This octagonal token is $27 \mathrm{~mm}$ in diameter and made from cuprous metal. No date is present. Since the standard publication on Texas trade tokens lists these alphabetically by location of the issuing firm and the location is not listed on the token, no information is available on this specimen. Trade tokens were used in Texas from 1875 to 1935 , stimulated by the low availability of small change and currency and the difficulties of transportation. The earliest tokens probably were saloon tokens. Saloons were plentiful and competition keen, resulting in varied and ornate pictorial tokens in the last two decades of the nineteenth century. Tokens for free drinks were given in change when drinks were purchased. The tokens issued by saloons, retail merchandise firms, lumber companies, and others may have numbered in the thousands (Fowler et al. 1973:i, iii).

Another token commemorates William Henry Harrison, United States President for one month in 1841. The obverse contains a central bust of Harrison surrounded by raised lettering with serifs stating, at the top, "9TH PRESIDENT, U.S.A./ 1841/DIED," and, at the bottom, "WM HENRY HARRISON." The reverse contains similar lettering stating, at the top, "OLD TIPPECANOE," and, at the bottom, "THE WASHINGTON OF THE WEST." In the center is the inscription, "DEFEATED INDIANS/AT/TIPPECANOE/ MAJOR GENERAL 1812/DEFEATED BRITISH/ IN CANADA/UNITED STATES SENATOR/ MINISTER TO COLUMBIA [sic]/DIED/ONE MONTH AFTER/INAUGURATION." This round token is $26 \mathrm{~mm}$ (1 inch) in diameter and made of cuprous metal .06 inch thick. The political or economic context of this token is unknown, but it probably dates to the second or third quarter of the nineteenth century given its subject matter and inscription style.

\section{Other Artifacts}

\section{Sulphide Marble}

A clear glass sulphide marble 1 inch in diameter contains a silvery figurine of a reclining lamb (?). A faceted area below the figurine may be the remnants of a polished pontil mark, and opposite this scar is a faint irregularity which may be the remnants of the other pontil mark. Between the two marks is a $1 / 2$-inch-long groove resulting from free-blown glass manufacture.

Sulphides are 1-to-21/4-inch clear or tinted glass spheres containing white or silvery sulphide figurines of animals, children, or numerals. Pontil marks, when present, are well polished and hard to detect. The handmade variety was probably made in Germany from the mid nineteenth century to about World War I and perhaps into the mid 1920 s. Sulphides were listed in catalogs as glassfigured marbles in 1895 (Montgomery Ward \& Co. 1895:225), 1911, and 1914 (Randall 1979:15-16).

\section{Shutter Hinge}

One-half of a cast-iron window shutter hinge is the type advertised in an 1865 American hardware catalog (Russell and Erwin Manufacturing Company 1865:111). This is an example of Lull \& Porter's patented self-locking hinge with inside fastenings. The various-sized hinges opened the shutter $4 \frac{1}{4}$ to $61 \frac{1}{2}$ inches, and, if a 1 -inch space between the wall and shutter was left, the beveled surface against the butt would prevent the wind from closing the shutter. The portion with three screw holes for attachment to the shutter or window frame is approximately 3 inches high, and the mechanism plus attachment is $3 \frac{1}{2}$ inches wide. This shutter type was present on military buildings at the fort and is considered diagnostic of military construction.

\section{DISTRIBUTIONS OF SELECTED ARTIFACTS}

\section{Military Artifacts}

Military artifacts are present at the fort in low 
densities, possibly because of clean-up activities by military personnel, and their distributions are one of the most reliable indicators of the antebellum and postbellum military occupations that obviously were present at the fort but are so difficult to separate from the civilian occupation debris. Structures and rooms containing antebellum great coat, standing eagle, infantry, and dragoon buttons are Rooms 0 and 3 of Officers' Quarters 4, the Officers' Quarters 4 latrine, and Officers' Quarters 6. The 1853 dime from Room 3 of Officers' Quarters 4 is consistent with these antebellum military artifacts in indicating 1850 s occupation of Rooms 0 and 3 , with the latter room being the original wing which was set back from the front of Room 0 and not the second, presently standing, Room 3.

With the exception of the Officers' Quarters 4 latrine, each of these structures or rooms also contains postbellum military artifacts and those dating to either military occupation. Postbellum military artifacts from Officers' Quarters 6 are the cavalry saber insignia and Waterbury Button Company line eagle buttons, and the 1867 and 1869 nickels and the 1868 token are consistent in date with these military artifacts. Room 0 of Officers' Quarters 4 contained the postbellum carbine sling swivel and .45-70 U.S. government cartridge cases. Room 3 of Officers' Quarters 4 contained postbellum .58-caliber rimfire and .45-70 U.S. government cartridge cases. Military artifacts dating to either military occupation are the infantry horn insignia, line eagle and staff officer buttons, and shoulder scaleboards from Officers' Quarters 6 and the shoulder scaleboard fragments from Rooms 0 and 3 of Officers' Quarters 4.

Areas containing postbellum Waterbury Button Company line eagle buttons and .50-70 and .45-70 cartridge cases but no antebellum artifacts or artifacts spanning the pre- and post-Civil War periods are Officers' Quarters 3 and 11 and the south yard of Officers' Quarters 4. The south yard of Officers' Quarters 4 also contained a postbellum bit ornament. The 1878 dime from Officers' Quarters 11 is consistent with the postbellum military artifacts from this quarters. In the case of Officers' Quarters 3, however, bottles and ceramics indicate an antebellum occupation also was present.

Areas containing postbellum military artifacts and those dating to either military occupation are Officers' Quarters 1, 5, and 8; the east yard of
Officers' Quarters 4; Barracks 2 and 3; the Old Hospital; and the highway right-of-way. Officers' Quarters 1 contained postbellum Waterbury Button Company and Scovill Manufacturing Company line eagle buttons from either military occupation. The east yard of Officers' Quarters 4 contained postbellum .50-70 and .45-70 cartridge cases and Scovill Manufacturing Company, Horstmann \& Sons, staff officer, and illegibly marked line eagle buttons and knapsack parts from either military occupation. Officers' Quarters 5 produced the Colt Model 1860 army revolver and the D. Evans \& Company infantry button. Officers' Quarters 8 contained the postbellum .58-caliber rimfire cartridge cases and shoulder scaleboard fragments from either military occupation.

Barracks 2 contained postbellum regimental number insignia and regimental number and infantry horn insignia and unmarked-manufacturer line eagle buttons from either military occupation. Barracks 3 produced the postbellum canteen stopper and .45-70 cartridge cases. The Old Hospital contained postbellum .45-70 cartridge cases and company letter insignia and Scovill Manufacturing Company and unmarked line eagle buttons from either military occupation. The highway right-ofway produced postbellum .50-70 and .45-70 cartridge cases and shoulder scaleboard fragments and knapsack parts from either military occupation.

It is likely that a lack of material evidence of antebellum military occupation is not a reliable indicator of lack of military occupation because of the low artifact densities involved. The low density of military artifacts probably also does not reflect a low intensity of occupation, but rather thorough clean-up activities and civilian-period collecting.

\section{Ceramics}

The distribution of ceramic types by structure provides limited information on the pre- and post-Civil War and nineteenth-century early civilian occupations at the fort. Unfortunately, the time ranges for the various ceramic decoration and mark types crosscut the dates of the two military and civilian occupations so that few decoration types can be assigned to a single occupation. The numbers of sherds are so few apparently because the site was kept clean during the military occupations. These distributions are not substantial 
enough for detailed interpretation.

Officers' Quarters 4 is discussed first because this structure was excavated extensively. Room 0 contained a sponge-stamped sherd and a painted sherd potentially dating to either military occupation. Room 1 contained a sherd from the same sponge-stamped vessel as well as flow blue dating to either military occupation. Also present was shell edge and monochrome decal-decorated semivitreous whiteware dating to the post-Civil War military or civilian occupation. Room 2 contained molded ironstone dating to either military occupation and shell edge dating to the post-Civil War military or civilian occupation. Room 3 contained the Edge Malkin \& Co. Verona pattern mark dating 1873-1899 and associated with either the second military occupation or the early civilian occupation and a possibly twentieth-century annular swirled pattern.

Exterior proveniences also contained a mixture of types. The east yard with the two-room kitchen contained shell edge and molded luster dating to the second military or the early civilian occupation. The back yard contained flow blue and handtinted transfer dating to either military occupation, a Burgess and Goddard mark dating to the postCivil War occupation, and tea leaf luster and a Grosvenor stoneware mark dating to the post-Civil War military or early civilian occupation. The area between Officers' Quarters 4 and 5 contained flow blue probably dating to either military occupation and overglaze transfer, enameled luster, and open sponge dating to one of the nineteenthcentury occupations.

Officers Quarters 1 contained an open-spongedecorated whiteware dating to any of the three occupations. Officers' Quarters 3 contained the Priory transfer pattern dating to the first military occupation. Officers' Quarters 5 contained a molded whiteware dating to either military occupation. Officers' Quarters 6 contained a pink luster fluted cup probably dating to the pre-Civil War occupation, sponge spatter dating to either of the military occupations, and banded annular possibly dating to the early civilian occupation. The Old Hospital contained another vessel with the Priory transfer pattern dating to the first military occupa- tion. The highway right-of-way contained a flow blue pattern, possibly Vincennes, dating to the pre-Civil War military occupation, and shell edge dating to the second military occupation or the early civilian occupation.

In summary, ceramic evidence of the pre-Civil War military occupation was found in Officers' Quarters 3 and 6, the Old Hospital, and the highway right-of-way. A mark from the post-Civil War military occupation was found in the Officers' Quarters 4 back yard. Ceramics from either military occupation were found in all Officers' Quarters 4 proveniences except for Room 3 and the latrine and in Officers' Quarters 5 and 6. Ceramics from the post-Civil War military and nineteenth-century civilian occupations were found in Rooms 1, 2, and 3 and the east and back yards of Officers' Quarters 4 and in the highway rightof-way. Ceramic evidence of the nineteenthcentury civilian occupation was found in Officers' Quarters 6.

\section{Bottle Glass}

The bottle glass assemblage, like the decorated ceramic assemblage, includes scattered evidence of the military occupation of the fort. The assemblage is too small for extensive discussion of distributions. The bottle base with the Burlington Glass Co. mark occurred in Barracks 3. The possible bitters bottle base fragment was found in Officers' Quarters 6. Wine bottle fragments occurred in Officers' Quarters 3, 4, and 6; Barracks 6; the Old Hospital; the schoolhouse; and the highway right-of-way. Pontil-marked wine and ink bottles occurred in Officers' Quarters 3 and 4, the Old Hospital, and the highway right-of-way. Two umbrella inks occurred in Officers' Quarters 3 and one in the Commissary Storehouse.

\section{Tobacco Pipes}

The white ball clay pipes occur only in the Officers' Quarters 4 yard. Pipes made from colored firing clay occur in all Officers' Quarters 4 proveniences except for Room 1 and in Officers' Quarters 6 and the Old Hospital. 


\section{CONCLUSIONS}

The Fort McKavett archeological results are not comparable except in a very general way with those from other Texas frontier military forts (those owned by TPWD and others as well) because (1) excavation objectives and techniques have differed so greatly from fort to fort that the artifact assemblages probably do not represent similar contexts and (2) differing dates of occupation and locations affected the supply of materials to the various forts and the range of building materials available locally. Limited comparisons are made with the earlier work by TPWD at Forts McKavett and Richardson.

\section{COMPARISONS WITH PREVIOUS ARCHEOLOGICAL INVESTIGATIONS AT FORT MCKAVETT}

Most of the previous archeological work at Fort McKavett has shared common goals of restoring the buildings to their 1875 appearance. Restoration-driven excavations in buildings not containing deep deposits, which includes the majority of the military structures at the fort, generally were limited to tracing wall lines, searching for doors and windows, and exposing interior features such as fireplaces and interior walls. Areas with the potential for containing undisturbed military deposits (e.g., fireplaces and room corners) were completely excavated (Black and Ing 1980:70-71).

Previous archeological investigations at Fort McKavett have dealt with structures that are quite different from those reported here. This report primarily deals with officers' quarters and specialized structures such as the commissary storehouse, Old Hospital, and schoolhouse, with limited excavation in enlisted mens' barracks. Archeological work at Fort McKavett from 1969 until 1973 involved excavation in enlisted mens' Barracks 1, 3 , and 4 and the second bakery as well as location and excavation of the original flagpole and a nearby subterranean water reservoir that was part of an unfinished fire-fighting system. Archeological work from 1974 until 1977 included excavation in Barracks 2 and 3 and the first bakery/bakery storehouse.

The 1974 and 1976 work in the quartermaster workshops building differs from most of the work reported here in that, in addition to exposing the lower foundation courses for stabilization, each of the three rooms in this building was extensively excavated to attempt to identify activity areas associated with the four craftsmen (blacksmith, wheelwright, carpenter, and saddler) known to have utilized the structure. Hot forging was indicated by the presence of clinkers and possible forge remains, horseshoeing by shoeing nails, and leatherworking by the presence of rivets, burrs, and buckles (Black and Ing 1980:3, 239). Somewhat similar extensive excavations that were not entirely restoration driven took place in Officers' Quarters 4 rooms and yard in 1978 through 1985.

The quartermaster workshops building, first bakery/bakery storehouse, and Barracks 2 and 3 were modified after abandonment by the military, and all had been used as trash dumps during the twentieth century. Civilians used the quartermaster workshops building and yards for many years after they were abandoned by the military for picnicking, overnight camping, and as a corral (Black and Ing 1980:77). In contrast to most of the officers' quarters, however, the building apparently was not occupied on a long-term basis by civilians.

The quartermaster workshops building was 
atypical of Fort McKavett structures in that it contained a deep deposit whereas most buildings contained very thin deposits above bedrock. The deposit in the north and middle rooms indicated that the wall foundation was laid directly on exposed bedrock or on the thin mantle of black clay. A stratum of pink lime and sand mortar near the walls resulted from spillage while pointing the walls. A 1-2-ft-thick deposit of large limestone rubble and friable gray-brown sediment with few artifacts was introduced. This rubble zone comprised the majority of the unusually deep interior deposit. The top of this rubble zone became the surface upon which most military and militaryperiod artifacts accumulated. The building interior was used as a domestic dump until the 1940s, when the walls collapsed and covered the trash (Black and Ing 1980:3, 69, 77, 87).

The deposits at Barracks 2, in contrast, are similar to those encountered in structures reported here. The building was placed on bedrock overlain by a thin mantle of dark brown clay. Directly above the clay lay a zone of mortar and limestone spalls representing the original construction. Above the construction zone was a lens of brown sediments containing military artifacts and representing the military-period dirt floor used before the barracks was converted to a hospital and given a wood floor in 1856. Above the dirt floor was a zone of mortar, plaster, and limestone spalls representing the deterioration of the building after its first abandonment and its subsequent reconstruction after the Civil War. Above the rubble zone was a second dirt floor with military artifacts dating from the building's use without and then with a wood floor. Above this second dirt floor were shingles and roofing nails, probably dating from the roof's removal a few years after final abandonment. Above the roofing debris was a layer of fallen wall rubble containing both military and civilian artifacts and representing the final razing of the barracks and removal of most of the building materials for use elsewhere (Black and Ing 1980:141).

\section{COMPARISONS WITH FORT RICHARDSON}

Like Fort McKavett, occupied after the Civil War from 1868 until 1883, Fort Richardson in north Texas west of Denton was the site of a post-
Civil War frontier military occupation from 1867-1878. In addition Fort Richardson is suitable for limited comparison with Fort McKavett because of the similarities in post-military civilian occupation of the sites, in archeological goals and resulting field techniques, and in paucity of military artifacts. Both sites currently are managed by TPWD, and since a report on the 1978-1986 archeological work at Fort Richardson by TPWD is being finalized concurrent with the writing of this report, results of the latter work are available.

Use of the Fort Richardson buildings largely is undocumented after abandonment by the U.S. Army in 1878. Civilian settlers reportedly camped at the fort site until they could build their own homes, perhaps continuing to dismantle what remained of the fort buildings. For example, the barracks quickly fell into disrepair, perhaps completely disappearing by soon after the turn of the century. In the late nineteenth and early twentieth centuries, a railroad and post-military roads were built across the site. In 1936 the Texas Centennial Commission purchased the fort property and repaired the few remaining structures, rebuilding the single standing frame officers' quarters with material gathered from other structures at the site. Additional alterations were made by the City of Jacksboro, the National Guard, and the Jack County Historical Society. During the twentieth century, for example, the area of the barracks was used by the local civilian population, the National Guard, and the Jacksboro utilities department. Yet despite these modifications in the 115 years since the fort was occupied by the U.S. Army, substantial subsurface remains exist in all locations tested (Black and Kegley 1995).

The role of archeology in the development plan for both of these forts was constrained to unearthing architectural details in support of reconstruction of the buildings and to collecting material remains that were exposed in the course of this work. Testing designed to answer these kinds of questions is not necessarily suited to collecting a sample of artifacts useful for interpreting frontier military lifeways. By definition, architectural-based excavation has limited use in locating activity areas within and outside the structure. Contexts not sampled at Fort Richardson generally included room interiors, except for chimney foundations and interior walls; exterior areas, except for walkways; and other special- 
purpose features, such as trash dumps (Black and Kegley 1995). By contrast, more of these types of contexts most useful for interpretation were tested at Fort McKavett. For example, room interiors of certain structures, particularly Officers' Quarters 4 and 6, and exteriors at Officers' Quarters 4 were excavated.

Most development projects at state historical parks involving archeological work have been small in scale and limited to one fiscal year at a time. These small-scale projects at Forts Richardson and McKavett have generated small-scale testing efforts that have forced examination of the site deposits as islands of discontinuous stratigraphy (Black and Kegley 1995). Stratigraphic correlation may become impossible with such a piecemeal approach, whether or not the site deposits originally were correlatable. The discontinuous nature of the testing makes development of a comprehensive view of these forts difficult.

Both the Forts McKavett and Richardson deposits are described as shallow in depth and the artifact assemblage as chronologically mixed. The contexts at Fort Richardson most likely to contain military artifacts were deposits from the guardhouse and from Officers' Quarters J10. All other artifacts were collected from areas almost certainly occupied or disturbed after the site's abandonment by the frontier military.

The assemblage from the guardhouse at Fort Richardson included a substantial sample of postmilitary artifacts. Trash outside the north wall of the 1872 guardhouse annex accumulated both military and civilian trash through the first half of the twentieth century. This deposit was situated on the side of the building away from the parade ground and thus may have been cleaned less than the side facing the parade ground. The interior of the annex, which was rebuilt sometime after the military's departure, however, contained no military artifacts at all (Black and Kegley 1995).

Officers' Quarters J10 at Fort Richardson was a picket structure that burned in 1879 and apparently was never rebuilt, creating potential for a sealed military deposit. The artifact assemblage, however, proved to be small $(\mathrm{n}=1,282$, primarily architectural artifacts), with only a spent $.45-70$ cartridge and some lead fragments assignable to the military occupation. Apparently, little material was deposited either before or after the fire.

Artifact assemblages from these two military occupations of frontier Texas forts were sparse. Definitely military artifacts, such as ordnance, buttons, insignia, and equipment, from Fort Richardson number approximately 100 and comprise only 0.53 percent of the assemblage. The 10 years during which Fort Richardson operated as a frontier fort was a relatively short period of time for the accumulation of substantial deposits. The approximately 200 military artifacts from Fort McKavett, although twice as numerous as those from Fort Richardson, represent less than 0.01 percent of the total artifact assemblage. The 23 years of Fort McKavett's military occupation provided slightly greater opportunity for deposition of military artifacts than at Fort Richardson. In addition the broader-scale excavation of room interiors and yards at Fort McKavett afforded greater potential than at Fort Richardson for encountering these deposits archeologically.

The natural deposits at the site, consisting of exposed limestone bedrock or a thin clay mantle over bedrock, are relatively unstratified and are not generally conducive to rapid burial of large artifacts but, rather, to exposure of artifacts and trampling into small artifacts. Many of the artifacts were reduced to nonrecognizable fragments or collected by later residents. At forts that were later occupied by civilians, as at Forts McKavett and Richardson, military artifacts that remained on site after clean-up activities have been subject to a century of scavenging by later residents (Black and Kegley 1995).

Artifacts diagnostic of the civilian occupations are present in the deposits around all structures in both former forts. This pattern is expected for locations adjacent to towns which have lasted 10 times as long as the military post, in the case of Fort Richardson (Black and Kegley 1995), and 4 times as long as the military occupation, in the case of Fort McKavett.

In addition to the lack of stratigraphic separation, several artifact classes cannot be attributed unambiguously either to the military or to the civilian occupations. For example, cut nails and window glass were not analyzed beyond cataloging because of two factors: (1) the architectural bias of the artifact sample collected through excavating wall lines, fireplaces, and room corners; and (2) the inability to distinguish military from later civilian materials (Black and Ing 1980:203). Together, these and other ambiguous classes, such 
as undecorated white earthenware ceramics and nondiagnostic glass bottle sherds, represent a large proportion of the artifact assemblage.

Difficulties in recognizing military-period artifacts when individual fragments are small and nondiagnostic compound the problem of sparse military artifact assemblages not contained within stratified deposits. Small, noncrossmending fragments from beer, wine, whiskey, or medicine bottles or whiteware ceramics lacking in diagnostic attributes are not particularly useful in describing military lifeways. The nearly complete bottles from the Officers' Quarters 3 pit latrine, which was excavated in 1977 and is not technically part of the work reported here, were included in the artifact analysis because they exemplified militaryperiod bottles that were not well preserved elsewhere in the assemblage.

The military and military-period artifacts described in this report likely represent only a small proportion of the trash generated by the military occupations. Much of that trash probably was disposed of and possibly burned off-site or, if on-site, in pit latrines or other deep features not excavated during the 1978-1990 work. Limited on-site trash burning may be indicated by the fact that only 2 percent of the vertebrate remains from Officers' Quarters 4 are burned, and 26 percent of these are from the tray-type latrine behind this quarters. The military assemblage includes those objects that were lost under wood floors, that were too small or not visible enough to be recognized and collected by military personnel or civilian collectors, or that were buried rapidly at the time of their deposition. Military conduct, discipline, and policing may have functioned in keeping public spaces at frontier military forts relatively litter free, and thus artifact poor.

The primary goal of the archeological work was to provide data to identify the military architecture at the site by its style and technology and by its stratigraphic and artifact associations and to reconstruct selected military buildings as accurately as possible. Two types of products resulted from the work: the material culture described in this report and the reconstructed buildings now standing at the park. A more concrete appreciation for the romantic aspects of the fort's history can be obtained by visiting the site, where it is possible to stand on the parade ground surrounded by both standing and ruined officers' quarters and barracks and to experience the present-day isolation of the post, which is reminiscent of its frontier isolation during military occupation. On the other hand, an appreciation for the practical aspects of the fort's history can be gained readily by walking through the reconstructed quarters and barracks, keeping in mind that these cramped living quarters often were shared by several officers, their families, and their servants, who cooked, ate, and slept in these small rooms. Together, this report and the architectural fabric, museum displays, and interpretive material at Fort McKavett State Historical Park present complementary views of the history of the site. 


\section{REFERENCES CITED}

Amarillo Reporter

American Clay Pipe Works, Inc.

ca. 1915- Catalog. Reprinted by S. Paul Jung, Jr., Bel 1920 Air, Maryland.

Anonymous

n.d. Fort McKavett. Undated typescript marked "possibly copied from files belonging to Clara Wilkinson" in historical files at Fort McKavett State Historical Park, Menard County, Texas.

Austin American

Barber, John L.

1987 The Rimfire Cartridge in the United States \& Canada: An Illustrated History of its Manufacturers and Their Products 1857 to 1984. Armory Publications, Tacoma, Washington.

Barnes, Frank C.

1989 Cartridges of the World. 6th ed. DBI Books, Inc., Northbrook, Illinois.

Bazelon, Bruce S., and William F. McGuinn

1990 A Directory of American Military Goods Dealers \& Makers, 1785-1915. REF Typesetting \& Publishing, Inc., Manassas, Virginia.

Beirschwale, Margaret

1966 Fort McKavett, Texas: Post on the San Saba. Anson Jones Press, Salado, Texas.

Black, Art, and J. David Ing

1980 Fort McKavett State Historic Site, Menard County, Texas, Archeological Investigations 1974-1977. Texas Parks and Wildlife
Department, Historic Sites and Restoration Branch, Austin.

Black, Arthur, and George Kegley

1995 Fort Richardson State Historical Park, Jack County, Texas: Archeological Testing and Recording, 1978, 1979, 1981, 1985, 1986.

Draft report submitted to the Department of Antiquities Protection by the Texas Parks and Wildlife Department, Public Lands Division, Cultural Resources Program, Austin.

Brinckerhoff, Sidney B.

1976 Metal Uniform Insignia of the Frontier U.S. Army 1846-1902. Museum Monograph 3 (revised and enlarged). Arizona Historical Society, Tucson.

Carlson, Paul H.

1982 Texas Woolybacks: The Range Sheep and Goat Industry. Texas A\&M University Press, College Station, Texas.

Coysh, A. W., and R. K. Henrywood

1982 The Dictionary of Blue and White Printed Pottery 1780-1880. Antique Collectors' Club, Woodbridge, Suffolk, England.

1989 The Dictionary of Blue and White Printed Pottery 1780-1880. Vol. 2. Antique Collectors' Club, Woodbridge, Suffolk, England.

Crimmins, M. L. (editor)

1938- Colonel J. K. F. Mansfield's Report on the 1939 Inspection of the Department of Texas in 1856. Southwestern Historical Quarterly 42:122-148 (Oct. 1938), 215-259 (Jan. 1939), 351-387 (April 1939). 
Cunningham, Eugene

1934 The Alcalde of Fort McKavett. Frontier Times 11:300-306.

DeBolt, C. Gerald

1988 The Dictionary of Whiteware and Porcelain American Pottery Marks. Charles E. Tuttle Co., Rutland, Vermont.

Fike, Richard E.

1987 The Bottle Book: A Comprehensive Guide to Historic, Embossed Medicine Bottles. Gibbs M. Smith, Inc., Peregrine Smith Books, Salt Lake City.

Fort McKavett Breeze

Fowler, William E., Travis L. Roberts, and

Harry L. Strough

1973 The Trade Tokens of Texas. TAMS Journal (Official Organ of the Token and Medal Society) 13(2), Part II.

Fox, Daniel E

1983 Traces of Texas History: Archeological Evidence of the Past 450 years. Corona Publishing Co., San Antonio.

Garza, Michael A.

1995 Interview by John Leffler at Fort McKavett, June 23 and June 25, 1995.

Gaston, Mary F.

19834 The Collectors Encyclopedia of Flow Blue China. Collector Books, Paducah, Kentucky.

1994 Collector's Encyclopedia of Flow Blue China, Second Series. Collector Books, Paducah, Kentucky.

Gates, William C., Jr., and Dana E. Ormerod

1982 The East Liverpool, Ohio, Pottery District: Identification of Manufacturers and Marks. Historical Archaeology 16(1-2):1-358.

Godden, Geoffrey A.

1964 Encyclopedia of British Pottery and Porcelain Marks. Crown Publishers, Inc., New York.

Green, F. E.

1969 Preliminary Archaeological Investigations at Fort McKavett, Texas. Ms. on file, Texas
Tech University, Lubbock.

Grist, Everett

1993 Everett Grist's Big Book of Marbles: A Comprehensive Identification and Value Guide for Both Antique and Machine-made Marbles. Collector Books, Paducah, Kentucky.

Hernandez, Porfirio

1995 Interview by John Leffler at the home of Clara Saucedo, Menard, Texas, June 24, 1995.

Herskovitz, Robert M.

1978 Fort Bowie Material Culture, Anthropological Papers No. 31. The University of Arizona Press, Tucson.

Horstmann Bros. \& Co.

1972 Catalogue of Military Goods for 1877. Manor Publishing Co., Staten Island, New York.

Hunter, John Warren

1924 Killing of John Vaden at Ft. McKavett. Frontier Times 2:16-18.

Hunter, J. M.

1954 Old Fort McKavett. Frontier Times 31:200-204.

Hunter, Robert R., Jr., and George L. Miller

1994 English Shell-Edged Earthenware. Antiques 145(3):432-443.

Huntington, R. T.

1967 Dragoon Accouterments and Equipments, 1834-1849: An Identification Guide. Plains Anthropologist 12(38):345-355.

Hutchins, James S

1976 Boots \& Saddles at the Little Bighorn: Weapons, Dress, Equipment, Horses, and Flags of General Custer's Seventh U.S. Cavalry in 1876. Source Custeriana Series 7. The Old Army Press, Fort Collins, Colorado.

Ing, J. David, and John Hart

1987 Archeological Excavations at Fanthorp Inn State Historic Site (41GM79), Grimes County, Texas, Spring and Fall 1982. Historic Sites 
and Restoration Branch, Texas Parks and Wildlife Department, Austin.

Jacobsen, Jacques N., Jr.

1972 Forward. In Horstmann Bros. and Co. Catalogue of Military Goods for 1877. Manor Publishing Co., Staten Island, New York.

Johnson, David F.

1948 Uniform Buttons, American Armed Forces 1784-1948, Vol. I: Descriptions \& Values, and Vol. II: Illustrations \& Index. Century House, Watkins Glen, New York.

Jones, Olive, and Catherine Sullivan

1989 The Parks Canada Glass Glossary. Rev. ed. National Historic Parks and Sites, Canadian Parks Service, Ottawa.

Katcher, Philip

1989 U.S. Infantry Equipments, 1775-1910. Osprey Men-at-Arms Series, No. 214. Osprey Publishing, London.

Ketchum, William C., Jr.

1987 American Country Pottery: Yellowware and Spongeware. Alfred A. Knopf, New York.

Kovel, Ralph, and Terry Kovel

1986 Kovel's New Dictionary of Marks. Crown Publishers, Inc., New York.

Lehne, Louis

1995 Interviewed at his home in Menard, Texas, June 25, 1995, by John Leffler.

Lehner, Lois

1988 Lehner's Encyclopedia of U.S. Marks on Pottery, Porcelain \& Clay. Collector Books, Paducah, Kentucky.

Lockett, Terence A.

1972 Davenport Pottery and Porcelain: 17941887. Charles E. Tuttle, Inc., Rutland, Vermont.

Lockett, Terence A., and Geoffrey A. Godden

1989 Davenport China, Earthenware, Glass. Barrie \& Jenkins, London.

Logan, Herschel C.

1959 Cartridges: A Pictorial Digest of Small Arms Ammunition. Bonanza Books, New York.
Lord, Francis A.

1982 Civil War Collector's Encyclopedia: Arms, Uniforms, and Equipment of the Union and Confederacy. Castle, Secaucus, New Jersey.

Majewski, Teresita, and Michael J. O'Brien

1987 The Use and Misuse of Nineteenth-Century English and American Ceramics in Archaeological Analysis. In Advances in Archaeological Method and Theory, vol. 11, edited by Michael B. Schiffer, pp. 97-209. Academic Press, Inc., New York.

McChristian, Douglas C.

1995 The U.S. Army in the West, 1870-1880: Uniforms, Weapons, and Equipment. University of Oklahoma Press, Norman.

McGuinn, William F., and Bruce S. Bazelon

1990 American Military Button Makers and Dealers: Their Backmarks \& Dates. Rev. ed. BookCrafters, Inc., Chelsea, Mich.

Meador, Tom

n.d.a Frontier Justice. Undated typescript in files at Fort McKavett State Historical Park, Menard County, Texas.

n.d.b Killing of John Vaden. Undated typescript in files at Fort McKavett State Historical Park, Menard County, Texas.

Menard County Chamber of Commerce

1937 Historical Review of Menard and Menard County, Texas, featuring the Presidio de San Luis de las Amarillas. Pamphlet published by the Menard County Chamber of Commerce, [Menard?].

Menard County Historical Society (compiler)

1982 Menard County History: An Anthology. Anchor Publishing Co., Menard, Texas.

Miller, George L.

1991 A Revised Set of CC Index Values for Classification and Economic Scaling of English Ceramics from 1787 to 1880 . Historical Archaeology 25:1-25.

1993 A User's Guide to Ceramic Assemblages, Part Four: Some Thoughts on Classification of White Earthenwares. Council for Northeast Historical Archaeology Newsletter 26 (November). 
Montgomery Ward \& Co.

1895 Catalogue and Buyers' Guide No. 57 Spring and Summer. Unabridged facsimile reprint, 1969. Dover Publications, Inc., New York.

Moore, N. Hudson

1903 The Old China Book. Tudor Publishing Co., New York.

Munsey, Cecil

1970 The Illustrated Guide to Collecting Bottles. Hawthorn Books, New York.

Neumann, George C., and Frank J. Kravic

1975 Collector's Illustrated Encyclopedia of the American Revolution. Rebel Publishing Co., Inc., Texarkana, Texas.

Pearson, Emerson L., and Susan A. Carter

1973 Archeological Investigation of Architectural Details on Structures M2, V1, and X at Fort McKavett State Historic Site, Texas: An Interim Report. Research Report No. 20. Texas Archeological Survey, The University of Texas at Austin.

Peck \& Snyder

1886 Nineteenth Century Games \& Sporting Goods. Reprinted 1971. American Historical Catalog Collection. The Pyne Press, Princeton, New Jersey.

Peterson, Harold L.

1959 Notes on Ordnance of the American Civil War, 1861-1865. The American Ordnance Association, Washington, D.C.

Peterson, John A.

1988 Prairie Hinterland: The Archaeology of Palo Duro Creek: A Cultural Resources Inventory of the Palo Duro Reservoir, Hansford County, Texas. Archaeological Research, Inc., Austin.

Pierce, N. H. (compiler)

1966 The Free State of Menard: A History of the County. 2nd ed. Western Advertising Company, Menard, Texas.

Pool, Juliann C.

1987 Fanthorp Inn: A Study of Nineteenth and Twentieth Century Buttons. In Archeological
Excavations at Fanthorp Inn State Historic Site (4IGM79), Grimes County, Texas, Spring and Fall 1982, by J. David Ing and John Hart, pp. 277-293. Texas Parks and Wildlife Department, Historic Sites and Restoration Branch, Austin.

Powell, Edith Jerome

1940 Administrative Survey and a Proposed Plan of Reorganization for the Schools in Menard County, Texas. Master's thesis, University of Texas, Austin.

Praetzellis, Mary, Betty Rivers, and Jeanette K. Schulz 1983 Ceramic Marks from Old Sacramento. California Archeological Reports No. 22. California Department of Parks and Recreation, Sacramento.

Price, Cynthia R.

197919 th Century Ceramics in the Eastern Ozark Border Region. Center for Archaeological Research, Southwest Missouri State University, Springfield.

Randall, Mark E.

1979 Marbles as Historical Artifacts. Marble Collectors Society of America, Trumbull, Connecticut.

Reuland, Walter P.

1991 Cartridges for the Springfield Trap-door Rifles \& Carbines 1865-1898. Heritage Concepts, Laramie, Wyoming.

Robacker, Earl F., and Ada F. Robacker

1978 Spatterware and Sponge: Hardy Perennials of Ceramics. A. S. Barnes and Co., South Brunswick and New York.

Russell and Erwin Manufacturing Company 1865 Illustrated Catalogue of American Hardware. 1980 facsimile edition. Association for Preservation Technology.

Rust, Carol 1994 Tales from the Fort. Houston 'Chronicle Magazine, 16 January:8-15. Houston, Texas.

San Antonio Express

1929a Early Indian Outpost Now Houses Oil Scouts. 30 July. 
1929b Fort McKavett Sold for \$1,500. 29 October.

Saucedo, Clara

1995 Interviewed by John Leffler at her home in Menard, Texas, June 25, 1995.

Schuyler, Hartley \& Graham

1864 Illustrated Catalogue of Arms and Military Goods: Regulations for the Uniform Army, Navy, Marine and Revenue Corps of the United States. Schuyler, Hartley \& Graham, New York.

Sharpe, R., and S. M. Horton

1875 Fort McKavett, Texas. In A Report on the Hygiene of the United States Army, with Descriptions of Military Posts. War Department, Surgeon-General's Office, Circular No. 8. Government Printing Office, Washington, D.C.

Silber \& Fleming

ca. 1881 The Victorian Pattern Glass \& China Book. Reprinted 1990. Arch Cape Press, New York.

Smyrl, Vivian

1991a Fort McKavett, Texas. Typescript in New Handbook of Texas files, Texas State Historical Association, Austin.

1991b Menard County. Typescript in New Handbook of Texas files, Texas State Historical Association, Austin.

1991c Population and agricultural statistics for Menard County, Texas, drawn from published U.S. census reports, 1870-1980. In New Handook of Texas files, Texas State Historical Association, Austin.

Snyder, Jeffrey B.

1992 Flow Blue: A Collector's Guide to Pattern, History, and Values. Schiffer Publishing Ltd., West Chester, Pennsylvania.

1994 Historic Flow Blue with Price Guide. Schiffer Publishing Ltd., Atglen, Pennsylvania.

Streigler, W.

1962 The Life Story of G. W. Roberts, Jr. Typescript in scrapbook entitled "A Pictorial Album of Fort McKavett, Texas.”
Sudderth, W. E.

1992 The 1983 Archeological Excavations at the Ray House, Wilson's Creek National Battlefield, Missouri. Technical Report No. 15. National Park Service, Midwest Archeological Center, Lincoln, Nebraska.

Sullivan, Jerry M.

1981 Fort McKavett: A Texas Frontier Post. The Museum Journal 20. West Texas Museum Association, Texas Tech University, Lubbock. Reprinted 1993, Texas Parks and Wildlife Press, Austin.

Switzer, Ronald R.

1974 The Bertrand Bottles: A Study of 19th-Century Glass and Ceramic Containers. National Park Service, Washington, D.C.

Texas Almanac and Industrial Guide

1904- A. H. Belo, Dallas, Texas.

1950

Texas Parks and Wildlife Department

1969 Fort McKavett State Historic Park, Menard County, Texas. Parks Service Division, Texas Parks and Wildlife Department, Austin.

1975 Preservation Plan and Program for Fort McKavett State Historic Site, Menard County, Texas. Texas Parks and Wildlife Department, Historic Sites and Restoration Branch, Austin.

Texas State Gazetteer and Business Directory

R. L. Polk \& Co., Detroit, Michigan

Tolbert, Frank X.

1967100 Live Behind Thick Stone Walls. Dallas Morning News, 1 January.

Toulouse, Julian H.

1971 Bottle Makers and Their Marks. Thomas Nelson, Inc., New York.

Townsend, Frank C., and Frederick P. Todd

1956 Branch Insignia of Regular Cavalry, 18331872. Military Collector \& Historian 8(1): $1-5$.

Traister, John E.

1989 Antique Guns: The Collector's Guide. Stoeger Publishing Co., South Hackensack, New Jersey. 
Treadwell, Donald E.

n.d. A Pictorial Album of Ft. McKavett, Texas. Photocopied album in Fort McKavett vertical file at the Center for American History, The University of Texas at Austin.

U.S. Census, Manuscript Population Schedule 1870 Menard County, Texas

1900- Menard County, Texas

1940

Vinson, Carlos

1968 Collecting Shotshells. Gun Digest 22:91-97.

Waite, M. D. "Bud," and B. D. Ernst

1980 Trapdoor Springfield: The United States Springfield Single-shot Rifle 1865-1893. The Gun Room Press, Highland Park, New Jersey.

Webb, Walter Prescott (editor-in-chief)

1952 The Handbook of Texas. Vols. I and II. Texas State Historical Association, Austin.

Wetherbee, Jean

1985 A Second Look at White Ironstone. WallaceHomestead Book Co., Lombard, Illinois.

Whitall, Tatum \& Co.

1971 Druggists', Chemists' and Perfumers' Glassware. Originally published 1880 . American Historical Catalog Collection, Pyne Press, Princeton.

Williams, Petra

1978 Staffordshire Romantic Transfer Patterns: Cup Plates and Early Victorian China. Fountain House East, Jeffersontown, Kentucky.
1981 Flow Blue China: An Aid to Identification. Rev. ed. Fountain House East, Jeffersontown, Kentucky.

1986 Flow Blue China and Mulberry Ware Similarity and Value Guide. Rev. ed. Fountain House East, Jeffersontown, Kentucky.

1988 Flow Blue China II. Rev. ed. Fountain House East, Jeffersontown, Kentucky.

Williams, Petra, and Marguerite R. Weber

1986 Staffordshire II Romantic Transfer Patterns: Cup Plates and Early Victorian China. Fountain House East, Jeffersontown, Kentucky.

Williamson, Ada Lee Talbot (Pat)

1995 Interviewed by John Leffler at her ranch in Menard County, Texas, June 23, 1995.

Wilson, Rex L.

1981 Bottles on the Western Frontier. Edited by Edward Staski. The University of Arizona Press and Southwest Parks and Monuments Association, Tucson.

Winslow, Edith Black

1950 In Those Days: Memoirs of Edwards Plateau. The Naylor Co., San Antonio, Texas.

Wood, Richard H., and Virginia A. Wood

1975 A Catalogue of American Historical China Cup Plates, Baltimore, Maryland. Privately printed. Baltimore, Maryland.

Yeoman, R. S.

1975 A Guide Book of United States Coins. 29th rev. ed. Western Publishing Co., Inc., Racine, Wisconsin. 
APPENDIX A: Inventory of Military and Military-Period Artifacts 


\begin{tabular}{|c|c|c|c|}
\hline Lot & Provenience & Material Type & Artifact Type \\
\hline OQ $1 / 4$ & OQ 1, Room 5 & cuprous metal & military button \\
\hline OQ $1 / 4$ & OQ 1, Room 5 & ceramic & decorated whiteware \\
\hline OQ $1 / 11$ & OQ 1, Room 5 & cuprous metal & military button \\
\hline OQ $1 / 11$ & OQ 1, Room 5 & ceramic & decorated whiteware \\
\hline $\mathrm{OQ} 3 / 1$ & OQ 3, Latrine & olive green glass & bottle \\
\hline $\mathrm{OQ} 3 / 2$ & OQ 3, Latrine & ceramic & decorated whiteware \\
\hline $\mathrm{OQ} 3 / 2$ & OQ 3, Latrine & cuprous metal & military button \\
\hline $\mathrm{OQ} 3 / 2$ & OQ 3, Latrine & olive green glass & bottle \\
\hline $\mathrm{OQ} 3 / 2$ & OQ 3, Latrine & olive green glass & bottle \\
\hline $\mathrm{OQ} 3 / 3$ & OQ 3, Latrine & olive green glass & bottle \\
\hline$O Q 3 / 3$ & OQ 3, Latrine & aqua glass & bottle \\
\hline $\mathrm{OQ} 3 / 3$ & OQ 3, Latrine & aqua glass & bottle \\
\hline $\mathrm{OQ} 4 / 26$ & OQ 4, Room 0 & lead & shot \\
\hline OQ 4/27 & OQ 4, Room 0 & ceramic & tobacco pipe \\
\hline OQ 4/27 & OQ 4, Room 0 & clear glass and sulphide & sulphide marble \\
\hline OQ 4/32 & OQ 4, Room 0 & lead & bullet \\
\hline OQ 4/32 & OQ 4, Room 0 & cuprous metal & military button \\
\hline $\mathrm{OQ} 4 / 32$ & OQ 4, Room 0 & cuprous metal & military button \\
\hline OQ 4/32 & OQ 4, Room 0 & ferrous metal & equipage \\
\hline 695 & OQ 4, Room 0 & steel & trigger guard \\
\hline 763 & OQ 4, Room 0 & cuprous metal & cartridge case \\
\hline 767 & OQ 4, Room 0 & lead & shot \\
\hline 808 & OQ 4, Room 0 & ceramic & decorated whiteware \\
\hline 812 & OQ 4, Room 0 & cuprous metal & percussion cap \\
\hline 814 & OQ 4, Room 0 & cuprous metal & percussion cap \\
\hline 815 & OQ 4, Room 0 & cuprous metal & shoulder scale \\
\hline 821 & OQ 4, Room 0 & lead & bullet \\
\hline 828 & OQ 4, Room 0 & cuprous metal & percussion cap \\
\hline 828 & OQ 4, Room 0 & cuprous metal & percussion cap \\
\hline 828 & OQ 4, Room 0 & cuprous metal & percussion cap \\
\hline 838 & OQ 4, Room 0 & cuprous metal & percussion cap \\
\hline 839 & OQ 4, Room 0 & ceramic & decorated whiteware \\
\hline 839 & OQ 4, Room 0 & ceramic & decorated whiteware \\
\hline 844 & OQ 4, Room 0 & cuprous metal & cartridge case \\
\hline 844 & OQ 4, Room 0 & ceramic & marked stoneware \\
\hline 855 & OQ 4, Room 0 & olive green glass & bottle \\
\hline 860 & OQ 4, Room 0 & cuprous metal & percussion cap \\
\hline 860 & OQ 4, Room 0 & cuprous metal & percussion cap \\
\hline
\end{tabular}




\begin{tabular}{|c|c|c|c|}
\hline Lot & Provenience & Material Type & Artifact Type \\
\hline 730 & OQ 4, Room 1 & cuprous metal & percussion cap \\
\hline 730 & OQ 4, Room 1 & ceramic & decorated whiteware \\
\hline 745 & OQ 4, Room 1 & ceramic & decorated whiteware \\
\hline 766 & OQ 4, Room 1 & ceramic & decorated whiteware \\
\hline 776 & OQ 4, Room 1 & ceramic & decorated whiteware \\
\hline 786 & OQ 4, Room 1 & lead & bullet \\
\hline 787 & OQ 4, Room 1 & cuprous metal & cartridge case \\
\hline 788 & OQ 4, Room 1 & ceramic & decorated whiteware \\
\hline 791 & OQ 4, Room 1 & lead & bullet \\
\hline 680 & OQ 4, Room 2 & ceramic & decorated whiteware \\
\hline 680 & OQ 4, Room 2 & ceramic & tobacco pipe \\
\hline 691 & OQ 4, Room 2 & ceramic & decorated whiteware \\
\hline 691 & OQ 4, Room 2 & ceramic & decorated whiteware \\
\hline 703 & OQ 4, Room 2 & cuprous metal & cartridge case \\
\hline 709 & OQ 4, Room 2 & ceramic & tobacco pipe \\
\hline 712 & OQ 4, Room 2 & olive green glass & bottle \\
\hline 712 & OQ 4, Room 2 & olive green glass & bottle \\
\hline 718 & OQ 4, Room 2 & ceramic & decorated whiteware \\
\hline 720 & OQ 4, Room 2 & cuprous metal & percussion cap \\
\hline 724 & OQ 4, Room 2 & ceramic & decorated whiteware \\
\hline 724 & OQ 4, Room 2 & ceramic & decorated whiteware \\
\hline 724 & OQ 4, Room 2 & ceramic & decorated whiteware \\
\hline $\mathrm{OQ} 4 / 30$ & OQ 4, Room 3 & olive green glass & bottle \\
\hline OQ 4/31 & OQ 4, Room 3 & ceramic & decorated whiteware \\
\hline 570 & OQ 4, Room 3 & ceramic & decorated whiteware \\
\hline 604 & OQ 4, Room 3 & ceramic & decorated whiteware \\
\hline 614 & OQ 4, Room 3 & ceramic & tobacco pipe \\
\hline 602 & OQ 4, Room 3 & ceramic & decorated whiteware \\
\hline 623 & OQ 4, Room 3 & ceramic & decorated whiteware \\
\hline 625 & OQ 4, Room 3 & cuprous metal & shoulder scale \\
\hline 625 & OQ 4, Room 3 & cuprous metal & cartridge case \\
\hline 625 & OQ 4, Room 3 & ceramic & decorated whiteware \\
\hline 634 & OQ 4, Room 3 & silver & coin \\
\hline 638 & OQ 4, Room 3 & ceramic & decorated and marked whiteware \\
\hline 638 & OQ 4, Room 3 & ceramic & decorated whiteware \\
\hline 646 & OQ 4, Room 3 & cuprous metal & percussion cap \\
\hline 647 & OQ 4, Room 3 & ceramic & decorated whiteware \\
\hline 652 & OQ 4, Room 3 & cuprous metal & cartridge case \\
\hline
\end{tabular}


Appendix A: Inventory of Military and Military-Period Artifacts

\begin{tabular}{|c|c|c|c|}
\hline Lot & Provenience & Material Type & Artifact Type \\
\hline 658 & OQ 4, Room 3 & cuprous metal & military button \\
\hline 658 & OQ 4, Room 3 & ceramic & decorated whiteware \\
\hline 659 & OQ 4, Room 3 & ceramic & decorated whiteware \\
\hline 659 & OQ 4, Room 3 & ferrous metal & tobacco tag \\
\hline 659 & OQ 4, Room 3 & cuprous metal & cartridge case \\
\hline 663 & OQ 4, Room 3 & cuprous metal & cartridge case \\
\hline 574 & OQ 4, Room 3 & cuprous metal & cartridge case \\
\hline 604 & OQ 4, Room 3 & cuprous metal & cartridge case \\
\hline 605 & OQ 4, Room 3 & cuprous metal & percussion cap \\
\hline 616 & OQ 4, Room 3 & cuprous metal & cartridge case \\
\hline 617 & OQ 4, Room 3 & cuprous metal & cartridge case \\
\hline 623 & OQ 4, Room 3 & lead & shot \\
\hline $\mathrm{OQ} 4 / 9$ & OQ 4, Exterior east & cuprous metal & cartridge case \\
\hline OQ 4/11 & OQ 4, Exterior east & ceramic & decorated whiteware \\
\hline OQ 4/11 & OQ 4, Exterior east & brown glass & bottle \\
\hline OQ 4/11 & OQ 4, Exterior east & olive green glass & bottle \\
\hline OQ 4/12 & OQ 4, Exterior east & ceramic & decorated whiteware \\
\hline OQ 4/12 & OQ 4, Exterior east & cuprous metal & military button \\
\hline 500 & OQ 4, Exterior east & cuprous metal & cartridge case \\
\hline 508 & OQ 4, Exterior east & cuprous metal & cartridge case \\
\hline 527 & OQ 4, Exterior east & lead & shot \\
\hline 898 & $\mathrm{OQ} 4$, Exterior east & cuprous metal & cartridge case \\
\hline 902 & OQ 4, Exterior east & cuprous metal & military button \\
\hline 902 & OQ 4, Exterior east & cuprous metal & cartridge case \\
\hline 902 & OQ 4, Exterior east & ceramic & decorated whiteware \\
\hline 902 & OQ 4, Exterior east & ceramic & decorated whiteware \\
\hline 906 & OQ 4, Exterior east & cuprous metal & cartridge case \\
\hline 906 & OQ 4, Exterior east & aqua glass & pressed glass lid \\
\hline 907 & OQ 4, Exterior east & cuprous metal & cartridge case \\
\hline 908 & OQ 4, Exterior east & ceramic & decorated whiteware \\
\hline 909 & OQ 4, Exterior east & cuprous metal & military button \\
\hline 915 & OQ 4, Exterior east & aqua glass & pressed glass \\
\hline 915 & OQ 4, Exterior east & cuprous metal & percussion cap \\
\hline 915 & OQ 4, Exterior east & lead & bullet \\
\hline 915 & OQ 4, Exterior east & cuprous metal & equipage \\
\hline 915 & OQ 4, Exterior east & cuprous metal & equipage \\
\hline 917 & OQ 4, Exterior east & lead & bullet \\
\hline 917 & OQ 4, Exterior east & ceramic & decorated whiteware \\
\hline
\end{tabular}




\begin{tabular}{|c|c|c|c|}
\hline Lot & Provenience & Material Type & Artifact Type \\
\hline 923 & OQ 4, Exterior east & cuprous metal & cartridge case \\
\hline 928 & OQ 4, Exterior east & cuprous metal & cartridge case \\
\hline 930 & OQ 4, Exterior east & cuprous metal & cartridge case \\
\hline 930 & OQ 4, Exterior east & cuprous metal & military button \\
\hline 930 & OQ 4, Exterior east & ceramic & tobacco pipe \\
\hline 935 & OQ 4, Exterior east & cuprous metal & cartridge case \\
\hline 936 & OQ 4, Exterior east & ceramic & tobacco pipe \\
\hline 936 & OQ 4, Exterior east & cuprous metal & cartridge case \\
\hline 936 & OQ 4, Exterior east & cuprous metal & cartridge case \\
\hline 936 & OQ 4, Exterior east & cuprous metal & cartridge case \\
\hline 936 & OQ 4, Exterior east & cuprous metal & cartridge case \\
\hline 937 & OQ 4, Exterior east & cuprous metal & cartridge case \\
\hline 937 & OQ 4, Exterior east & cuprous metal & cartridge case \\
\hline 937 & OQ 4, Exterior east & cuprous metal & cartridge case \\
\hline 937 & OQ 4, Exterior east & cuprous metal & cartridge case \\
\hline 937 & OQ 4, Exterior east & cuprous metal & cartridge case \\
\hline 943 & OQ 4, Exterior east & cuprous metal & cartridge case \\
\hline 944 & OQ 4, Exterior east & ceramic & decorated whiteware \\
\hline 947 & OQ 4, Exterior east & cuprous metal & equipage \\
\hline 950 & OQ 4, Exterior east & cuprous metal & percussion cap \\
\hline 950 & OQ 4, Exterior east & cuprous metal & percussion cap \\
\hline 951 & OQ 4, Exterior east & cuprous metal & cartridge case \\
\hline 958 & OQ 4, Exterior east & cuprous metal & cartridge case \\
\hline 959 & $O Q 4$, Exterior east & cuprous metal & cartridge case \\
\hline 965 & OQ 4, Exterior east & lead & bullet \\
\hline 975 & OQ 4, Exterior east & cuprous metal & military button \\
\hline 978 & OQ 4, Exterior east & ceramic & tobacco pipe \\
\hline 979 & OQ 4, Exterior east & cuprous metal & military button \\
\hline 985 & OQ 4, Exterior east & cuprous metal & cartridge case \\
\hline 985 & OQ 4, Exterior east & cuprous metal & cartridge case \\
\hline 1040 & OQ 4, Exterior east & cuprous metal & cartridge case \\
\hline $\mathrm{OQ} 4 / 3$ & OQ 4, Exterior south & cuprous metal & cartridge case \\
\hline OQ 4/4 & OQ 4, Exterior south & ceramic & decorated whiteware \\
\hline $\mathrm{OQ} 4 / 4$ & OQ 4, Exterior south & ceramic & decorated whiteware \\
\hline $\mathrm{OQ} 4 / 4$ & OQ 4, Exterior south & cuprous metal & military button \\
\hline OQ 4/15 & OQ 4, Exterior south & ceramic & decorated whiteware \\
\hline OQ 4/36 & OQ 4, Exterior south & cuprous metal & cartridge case \\
\hline OQ 4/37 & OQ 4, Exterior south & ceramic & tobacco pipe \\
\hline
\end{tabular}


Appendix A: Inventory of Military and Military-Period Artifacts

\begin{tabular}{|c|c|c|c|}
\hline Lot & Provenience & Material Type & Artifact Type \\
\hline OQ 4/50 & OQ 4, Exterior south & ceramic & tobacco pipe \\
\hline OQ 4/50 & OQ 4, Exterior south & olive green glass & bottle \\
\hline OQ 4/52 & OQ 4, Exterior south & cuprous metal & cartridge case \\
\hline OQ 4/52 & OQ 4, Exterior south & cuprous metal & cartridge case \\
\hline OQ $4 / 55$ & OQ 4, Exterior south & olive green glass & bottle \\
\hline OQ 4/58 & OQ 4, Exterior south & ceramic & marked stoneware \\
\hline OQ 4/59 & OQ 4, Exterior south & cuprous metal & cartridge case \\
\hline OQ 4/61 & OQ 4, Exterior south & cuprous metal & cartridge case \\
\hline OQ 4/62 & OQ 4, Exterior south & ceramic & tobacco pipe \\
\hline OQ 4/62 & OQ 4, Exterior south & ceramic & decorated whiteware \\
\hline OQ 4/62 & OQ 4, Exterior south & cuprous metal & cartridge case \\
\hline OQ 4/62 & OQ 4, Exterior south & cuprous metal & cartridge case \\
\hline $\mathrm{OQ} 4 / 63$ & OQ 4, Exterior south & ceramic & decorated whiteware \\
\hline OQ 4/66 & OQ 4, Exterior south & ceramic & decorated whiteware \\
\hline OQ 4/69 & OQ 4, Exterior south & lead & bullet \\
\hline OQ 4/70 & OQ 4, Exterior south & cuprous metal & cartridge case \\
\hline OQ 4/70 & OQ 4, Exterior south & cuprous metal & cartridge case \\
\hline OQ 4/70 & OQ 4, Exterior south & cuprous metal & cartridge case \\
\hline OQ 4/72 & OQ 4, Exterior south & ceramic & marked whiteware \\
\hline 474 & OQ 4, Exterior south & ceramic & decorated whiteware \\
\hline 475 & OQ 4, Exterior south & ceramic & decorated whiteware \\
\hline 480 & OQ 4, Exterior south & lead & shot \\
\hline 482 & OQ 4, Exterior south & ceramic & decorated whiteware \\
\hline 499 & OQ4, Exterior south & ferrous metal & equipage \\
\hline 507 & OQ 4, Exterior south & ceramic & decorated yellowware \\
\hline 507 & OQ 4, Exterior south & ceramic & decorated whiteware \\
\hline 518 & OQ 4, Exterior south & ceramic & decorated whiteware \\
\hline 518 & OQ 4, Exterior south & ceramic & decorated whiteware \\
\hline 518 & OQ 4, Exterior south & ceramic & decorated yellowware \\
\hline 536 & OQ 4, Exterior south & ceramic & decorated whiteware \\
\hline 536 & OQ 4, Exterior south & ceramic & tobacco pipe \\
\hline 900 & OQ 4, Exterior south & ceramic & decorated whiteware \\
\hline 900 & OQ 4, Exterior south & ceramic & decorated whiteware \\
\hline 900 & OQ 4, Exterior south & ceramic & decorated whiteware \\
\hline 900 & OQ 4, Exterior south & ceramic & decorated whiteware \\
\hline 916 & OQ 4, Exterior south & ceramic & tobacco pipe \\
\hline 922 & OQ 4, Exterior south & cuprous metal & cartridge case \\
\hline 924 & OQ 4, Exterior south & ferrous metal & equipage \\
\hline
\end{tabular}




\begin{tabular}{|c|c|c|c|}
\hline Lot & Provenience & Material Type & Artifact Type \\
\hline OQ $4 / 40$ & OQ 4, Latrine & cuprous metal & military button \\
\hline OQ 4/40 & OQ 4, Latrine & olive green glass & bottle \\
\hline 1045 & OQ 4-5 & cuprous metal & cartridge case \\
\hline 1045 & OQ 4-5 & ceramic & decorated whiteware \\
\hline 1045 & OQ 4-5 & ceramic & decorated whiteware \\
\hline 1045 & OQ 4-5 & ceramic & decorated whiteware \\
\hline 1046 & OQ 4-5 & ceramic & decorated whiteware \\
\hline 1046 & OQ 4-5 & ceramic & decorated whiteware \\
\hline 1046 & OQ 4-5 & ceramic & decorated whiteware \\
\hline 1046 & OQ 4-5 & ceramic & decorated whiteware \\
\hline 1026 & OQ 5 & cuprous metal & trade token \\
\hline OQ 5/23 & OQ 5 Shed & ceramic & decorated whiteware \\
\hline OQ 5/44 & OQ 5 Shed & cuprous metal & cartridge case \\
\hline OQ 5/45 & OQ 5 Shed & ceramic & decorated whiteware \\
\hline OQ 5/46 & OQ 5 Shed & ceramic & decorated whiteware \\
\hline OQ 5/46 & OQ 5 Shed & ceramic & decorated whiteware \\
\hline OQ 5/55 & OQ 5 Shed & steel & pistol barrel \\
\hline OQ 5/59 & OQ 5 Shed & ceramic & decorated whiteware \\
\hline OQ 5/59 & OQ 5 Shed & ceramic & decorated whiteware \\
\hline OQ 5/61 & OQ 5 Shed, Room 1 & olive green glass & bottle \\
\hline 1516 & OQ 5 Shed, Room 1 & ceramic & decorated whiteware \\
\hline OQ $5 / 3$ & OQ 5 Shed, Room 3 & cuprous metal & military button \\
\hline OQ 5/19 & OQ 5 Shed, Room 4 & lead & bullet \\
\hline OQ $5 / 38$ & OQ 5 Shed, Room 4 & lead & bullet \\
\hline OQ 5/47 & OQ 5 Shed, Room 4 & ceramic & decorated whiteware \\
\hline 1034 & OQ 6 & cuprous metal & percussion cap \\
\hline OQ $6 / 10$ & OQ 6, Room 1 & cuprous metal & percussion cap \\
\hline OQ 6/11 & OQ 6, Room 1 & cuprous metal & insignia \\
\hline OQ 6/11 & OQ 6, Room 1 & cuprous metal & insignia \\
\hline OQ 6/11 & OQ 6, Room 1 & cuprous metal & military button \\
\hline OQ 6/15 & OQ 6, Room 1 & lead & shot \\
\hline OQ $6 / 15$ & OQ 6, Room 1 & cuprous metal & percussion cap \\
\hline OQ 6/17 & OQ 6, Room 1 & fluorescent colorless glass & pressed glass tumbler \\
\hline OQ 6/19 & OQ 6, Room 1 & lead & shot \\
\hline OQ 6/19 & OQ 6, Room 1 & lead & shot \\
\hline OQ 6/19 & OQ 6, Room 1 & cuprous metal & shoulder scaleboard \\
\hline OQ $6 / 20$ & OQ 6, Room 1 & olive green glass & bottle \\
\hline OQ $6 / 20$ & OQ 6, Room 1 & olive green glass & bottle \\
\hline
\end{tabular}




\begin{tabular}{|c|c|c|c|}
\hline Lot & Provenience & Material Type & Artifact Type \\
\hline$O Q 6 / 20$ & OQ 6, Room 1 & olive green glass & bottle \\
\hline OQ $6 / 20$ & OQ 6, Room 1 & olive green glass & bottle \\
\hline OQ 6/20 & OQ 6, Room 1 & olive green glass & bottle \\
\hline OQ 6/21 & OQ 6, Room 1 & cuprous metal & military button \\
\hline $\mathrm{OQ} 6 / 22$ & OQ 6, Room 1 & cuprous metal & percussion cap \\
\hline OQ 6/22 & OQ 6, Room 1 & cuprous metal & percussion cap \\
\hline $\mathrm{OQ} 6 / 22$ & OQ 6, Room 1 & cuprous metal & percussion cap \\
\hline OQ $6 / 23$ & OQ 6, Room 1 & cuprous metal & percussion cap \\
\hline OQ $6 / 23$ & OQ 6, Room 1 & cuprous metal & military button \\
\hline $\mathrm{OQ} 6 / 23$ & OQ 6, Room 1 & ceramic & decorated whiteware \\
\hline$O Q 6 / 23$ & OQ 6, Room 1 & cuprous metal & shoulder scaleboard \\
\hline OQ 6/23 & OQ 6, Room 1 & cuprous metal & clothing hook \\
\hline OQ 6/23 & OQ 6, Room 1 & ferrous metal & tobacco tag \\
\hline$O Q 6 / 23$ & OQ 6, Room 1 & cuprous metal & trade token \\
\hline OQ 6/23 & OQ 6, Room 1 & olive green glass & bottle \\
\hline OQ $6 / 23$ & OQ 6, Room 1 & olive green glass & bottle \\
\hline OQ 6/26 & OQ 6, Room 1 & fluorescent colorless glass & pressed glass \\
\hline OQ 6/26 & OQ 6, Room 1 & silver & coin \\
\hline OQ 6/26 & OQ 6, Room 1 & olive green glass & bottle \\
\hline OQ 6/28 & OQ 6, Room 1 & olive green glass & bottle \\
\hline OQ $6 / 28$ & OQ 6, Room 1 & olive green glass/cuprous metal & bottle with wire seal \\
\hline$O Q 6 / 31$ & OQ 6, Room 1 & ceramic & tobacco pipe \\
\hline$O Q 6 / 31$ & OQ 6, Room 1 & cuprous metal & military button \\
\hline OQ $6 / 31$ & OQ 6, Room 1 & cuprous metal & percussion cap \\
\hline $\mathrm{OQ} 6 / 31$ & OQ 6, Room 1 & cuprous metal & percussion cap \\
\hline $\mathrm{OQ} 6 / 31$ & OQ 6, Room 1 & cuprous metal & percussion cap \\
\hline OQ 6/31 & OQ 6, Room 1 & lead & bullet \\
\hline OQ 6/31 & OQ 6, Room 1 & ceramic & decorated whiteware \\
\hline OQ $6 / 31$ & OQ 6, Room 1 & cuprous metal & clothing hook \\
\hline $\mathrm{OQ} 6 / 34$ & OQ 6 , Room 1 & cuprous metal & percussion cap \\
\hline $\mathrm{OQ} 6 / 34$ & OQ 6, Room 1 & lead & bullet \\
\hline$O Q 6 / 35$ & OQ 6, Room 1 & ferrous metal & cork protector \\
\hline OQ 6/42 & OQ 6, Room 5 & ceramic & marked whiteware \\
\hline $\mathrm{OQ} 6 / 47$ & OQ 6, Room 3 & olive green glass & bottle \\
\hline$O Q 6 / 47$ & OQ 6, Room 3 & brown glass & bottle \\
\hline OQ $6 / 52$ & OQ 6, Room 1 & olive green glass/cuprous metal & bottle with wire seal \\
\hline OQ $6 / 58$ & OQ 6, Room 1 & cuprous metal & military button \\
\hline OQ 6/58 & OQ 6, Room 1 & silver & coin \\
\hline
\end{tabular}




\begin{tabular}{|c|c|c|c|}
\hline Lot & Provenience & Material Type & Artifact Type \\
\hline OQ 6/61 & OQ 6 , Room 3 & cuprous metal & military button \\
\hline OQ 6/61 & OQ 6 , Room 3 & ceramic & decorated whiteware \\
\hline OQ 6/61 & OQ 6 , Room 3 & lead & bullet \\
\hline OQ 6/67 & OQ 6, Room 3 & lead & bullet \\
\hline OQ 6/67 & OQ 6 , Room 3 & lead & bullet \\
\hline OQ $6 / 70$ & OQ 6 , Room 3 & cuprous metal & percussion cap \\
\hline OQ $6 / 70$ & OQ 6, Room 3 & cuprous metal & percussion cap \\
\hline OQ $6 / 73$ & OQ 6, Room 3 & cuprous metal & percussion cap \\
\hline OQ 6/73 & OQ 6, Room 3 & ceramic & tobacco pipe \\
\hline OQ 6/75 & OQ 6, Room 3 & cuprous metal & military button \\
\hline OQ $6 / 75$ & OQ 6, Room 3 & cuprous metal & percussion cap \\
\hline OQ $6 / 76$ & OQ 6 , Room 3 & ceramic & decorated whiteware \\
\hline OQ 6/76 & OQ 6, Room 3 & cuprous metal & percussion cap \\
\hline OQ 6/76 & OQ 6 , Room 3 & cuprous metal & percussion cap \\
\hline OQ 6/76 & OQ 6, Room 3 & cuprous metal & percussion cap \\
\hline OQ 6/76 & OQ 6, Room 3 & cuprous metal & percussion cap \\
\hline OQ 6/77 & OQ 6 , Room 3 & cuprous metal & percussion cap \\
\hline OQ 6/77 & OQ 6 , Room 3 & cuprous metal & percussion cap \\
\hline OQ 6/77 & OQ 6 , Room 3 & cuprous metal & percussion cap \\
\hline OQ 6/77 & OQ 6, Room 3 & cuprous metal & percussion cap \\
\hline OQ 6/89 & OQ 6, Room 3 & cuprous metal & military button \\
\hline 578 & OQ 6 Sink & brown glass & bottle \\
\hline 586 & OQ 6 Sink & fluorescent colorless glass & pressed glass \\
\hline 586 & OQ 6 Sink & fluorescent colorless glass & pressed glass \\
\hline 595 & OQ 6 Sink & lead & bullet \\
\hline $\mathrm{OQ} 7 / 1$ & OQ 7 & cuprous metal & token \\
\hline $\mathrm{OQ} 7 / 2$ & OQ 7 & ferrous metal & shot \\
\hline $\mathrm{OQ} 8 / 3$ & OQ 8 & cuprous metal & cartridge case \\
\hline $\mathrm{OQ} 8 / 3$ & OQ 8 & cuprous metal & cartridge case \\
\hline $\mathrm{OQ} 8 / 3$ & OQ 8 & cuprous metal & cartridge case \\
\hline $\mathrm{OQ} 8 / 3$ & OQ 8 & cuprous metal & cartridge case \\
\hline $\mathrm{OQ} 8 / 4$ & OQ 8 & cuprous metal & shoulder scaleboard \\
\hline 1115 & OQ 8 & cuprous metal & cartridge case \\
\hline OQ $9 / 10$ & OQ 9, Room 93 & ceramic & decorated whiteware \\
\hline OQ $11 / 4$ & OQ 11 & cuprous metal & cartridge case \\
\hline OQ $11 / 13$ & OQ 11, Room 4 & cuprous metal & cartridge case \\
\hline OQ 11/15 & OQ 11, Room 4 & cuprous metal & cartridge case \\
\hline 258 & OQ 11, Room 7 & silver & coin \\
\hline
\end{tabular}


Appendix A: Inventory of Military and Military-Period Artifacts

\begin{tabular}{|c|c|c|c|}
\hline Lot & Provenience & Material Type & Artifact Type \\
\hline 317 & OQ 11, Door C & cuprous metal & cartridge case \\
\hline 317 & OQ 11, Door C & cuprous metal & cartridge case \\
\hline 347 & Barracks 2 & cuprous metal & insignia \\
\hline 360 & Barracks 2 & cuprous metal & insignia \\
\hline 360 & Barracks 2 & cuprous metal & military button \\
\hline 368 & Barracks 2 & olive green glass & bottle \\
\hline 373 & Barracks 2 & cuprous metal & insignia \\
\hline 373 & Barracks 2 & aqua glass & bottle \\
\hline 373 & Barracks 2 & cuprous metal & military button \\
\hline 553 & Barracks 3 Shed & cuprous metal & equipage \\
\hline 553 & Barracks 3 Shed & cuprous metal & shoulder scaleboard \\
\hline 553 & Barracks 3 Shed & cuprous metal & equipage \\
\hline 553 & Barracks 3 Shed & cuprous metal & military button \\
\hline 553 & Barracks 3 Shed & cuprous metal & military button \\
\hline 553 & Barracks 3 Shed & cuprous metal & cartridge case \\
\hline 553 & Barracks 3 Shed & cuprous metal & cartridge case \\
\hline 553 & Barracks 3 Shed & cuprous metal & cartridge case \\
\hline 548 & Barracks 3 Shed & brown glass & bottle \\
\hline 548 & Barracks 3 Shed & brown glass & bottle \\
\hline 548 & Barracks 3 Shed & brown glass & bottle \\
\hline 548 & Barracks 3 Shed & brown glass & bottle \\
\hline 548 & Barracks 3 Shed & brown glass & bottle \\
\hline 548 & Barracks 3 Shed & brown glass & bottle \\
\hline 550 & Barracks 3 Shed & olive green glass & bottle \\
\hline 558 & Barracks 3 Shed & aqua glass and metal & bottle and cap \\
\hline 491 & Barracks 6 & olive green glass & bottle \\
\hline 447 & Commissary Storehouse & aqua glass & bottle \\
\hline 16 & Old Hospital & cuprous metal & cartridge case \\
\hline 30 & Old Hospital & cuprous metal & insignia \\
\hline 62 & Old Hospital & cuprous metal & equipage \\
\hline 62 & Old Hospital & cuprous metal & cartridge case \\
\hline 62 & Old Hospital & cuprous metal & cartridge case \\
\hline 65 & Old Hospital & cuprous metal & military button \\
\hline 121 & Old Hospital & brown glass & bottle \\
\hline 129 & Old Hospital & olive green glass & bottle \\
\hline 134 & Old Hospital & cuprous metal & cartridge case \\
\hline 141 & Old Hospital & cuprous metal & cartridge case \\
\hline 147.5 & Old Hospital & ceramic & tobacco pipe \\
\hline
\end{tabular}




\begin{tabular}{|c|c|c|c|}
\hline Lot & Provenience & Material Type & Artifact Type \\
\hline 149 & Old Hospital & cuprous metal & military button \\
\hline 150 & Old Hospital & ceramic & decorated whiteware \\
\hline 165 & Old Hospital & olive green glass & bottle \\
\hline 172 & Old Hospital & lead & bullet \\
\hline 173 & Old Hospital & brown glass & bottle \\
\hline 176 & Old Hospital & cuprous metal & cartridge case \\
\hline 191 & Old Hospital & cuprous metal & percussion cap \\
\hline 209 & Old Hospital & ceramic & decorated whiteware \\
\hline 209 & Old Hospital & ceramic & decorated whiteware \\
\hline 220 & Old Hospital & cuprous metal & military button \\
\hline 228 & Old Hospital & cuprous metal & identity tag \\
\hline 229 & Old Hospital & cuprous metal & cartridge case \\
\hline 233 & Old Hospital & ceramic & decorated whiteware \\
\hline 1091 & Schoolhouse & olive green glass & bottle \\
\hline 905 & Right of Way & ceramic & decorated whiteware \\
\hline 905 & Right of Way & ceramic & decorated whiteware \\
\hline 905 & Right of Way & ceramic & decorated whiteware \\
\hline 905 & Right of Way & ceramic & decorated whiteware \\
\hline 905 & Right of Way & ceramic & decorated whiteware \\
\hline 905 & Right of Way & cuprous metal & cartridge case \\
\hline 905 & Right of Way & olive green glass & bottle \\
\hline 905 & Right of Way & olive green glass & bottle \\
\hline 905 & Right of Way & olive green glass & bottle \\
\hline 905 & Right of Way & cuprous metal & shoulder scale \\
\hline 905 & Right of Way & cuprous metal & cartridge case \\
\hline 905 & Right of Way & cuprous metal & cartridge case \\
\hline 1000 & Right of Way & olive green glass & bottle \\
\hline 1010 & Right of Way & cuprous metal & equipage \\
\hline 1015 & Right of Way & cuprous metal & cartridge case \\
\hline none & none & ferrous metal & hinge \\
\hline
\end{tabular}




\section{APPENDIX B: Functional Classification of the Fort McKavett Military and Civilian Artifact Collection}

George Kegley

Texas Parks and Wildlife Department Austin, Texas 
A sample of artifacts spanning the period between the 1850 s and the 1970 s was recovered by TPWD archeologists at Fort McKavett, Texas, during excavations associated with park development. The excavations were conducted during the 1970 s and 1980 s and produced a large collection $(>100,000$ artifacts), the analysis of which has proceeded slowly. Artifacts recognized as belonging to the period of occupation by the United States Army (1853-1883, interrupted by the Civil War) are addressed in the body of the present report. The remaining sample, constituting 99 percent of all excavated artifacts, is addressed in this section of the report. The present work does not present the standard particularistic/ideographic type of analysis that characterizes much historical archeological reportage, but instead compares aspects of historic collections from a number of North American sites over a span of more than 2 centuries. The classificatory and analytic tools employed were proposed by Stanley South (1977) and Roderick Sprague (1980 1981) (Table 10).

Analysis and reporting of the data from Fort McKavett has not occurred in a vacuum. The work was initiated as part of a larger interest South (1977:321) identified as a "fluorescing historic site preservation-restoration-reconstruction" phenomena that stimulated much contemporary historical archeology. It was conducted for a mission-oriented agency whose objective was the development of an historical park. In common with work funded at most mission-oriented agencies, the excavations can be characterized as applied or developmental research as contrasted with pure research (Swannock 1975). The former is more likely to be ideographic in nature and concerned with gathering specific information with which to interpret the function, artifacts, or architectural configuration of a particular site or structure.

The primary cultural context of the site is undisputed as is the principal reason for its acquisition-the presence of substantial remains of a frontier military fort from the late nineteenth century. In practice, work accomplished at Fort McKavett had aspects of both developmental and pure research. Development goals were handily met and considerable portions of the site restored. The artifact sample was processed and encoded using a classificatory system proposed by Sprague (19801981) with the expectation that time would become available to complete a major report on the site.
Preliminary indications suggested to investigators that the site presented opportunities to go beyond the description of a frontier military post of the nineteenth century and address a larger context encompassing the entire historic occupation of the site, both military and civilian. The more inclusive context was suggested to investigators because of the substantial adaptive reuse of military buildings by the civilian population and by the recognition of the shallow depth of the archeological deposit.

When the army abandoned Fort McKavett in 1880 , the small settlement which had grown up around the fort did not disappear but continued as a part of the ranching industry of the Texas Hill Country. Civilians moved into the abandoned military structures and began adapting them in a tradition that continued over a century of postmilitary occupation.

The nature of the cultural deposit which formed in the shallow soils in the vicinity of the fort preserved little evidence of stratigraphic separation in 125 years of deposition. The military and civilian occupations also are not spatially separate and appear to share many material culture traits. Classes of ambiguous cultural materials are difficult, if not impossible, to separate between the military and civilian occupations. Such materials are undiagnostic glass body sherds from containers and white earthenware. Both classes provide relatively large samples of materials which equally could have come from a military or civilian cultural context. In the absence of diagnostic criteria, or stratigraphic separation, these classes are functionally identical and cannot be distinguished between military and civilian use.

In 1992, the Historic Sites and Restoration Branch of TPWD, which had primary responsibility for the collection and its analysis and reporting, ceased to exist. The level of analysis necessarily changed as personnel and resources changed. It was always recognized that the United States military component of the material cultural assemblage had priority since the site was not acquired because it was an interesting rural hamlet, but rather because it was considered to be a site of national heritage potential for its role in early frontier defense. Choices made about which materials would be included in the body of the present report reflect the intentional bias toward artifacts that can be assigned confidently to the period of military occupation.

By the time of acquisition by the state, relic collecting had resulted in the selection and removal 
TABLE 10

COMPARISON OF SOUTH AND SPRAGUE CLASSIFICATIONS OF THE FORT McKAVETT ARTIFACTS

\begin{tabular}{|c|c|c|c|c|c|}
\hline \multicolumn{3}{|c|}{ South Classification } & \multicolumn{3}{|c|}{ Sprague Classification } \\
\hline Group & $\begin{array}{l}\# \text { of } \\
\text { Specimens }\end{array}$ & $\begin{array}{l}\% \text { of } \\
\text { Total }\end{array}$ & Group & $\begin{array}{l}\text { \# of } \\
\text { Specimens }\end{array}$ & $\begin{array}{l}\% \text { Within } \\
\text { Group }\end{array}$ \\
\hline Kitchen & 57,634 & 56.68 & $\begin{array}{l}\text { Culinary } \\
\text { Gustatory } \\
\text { Medical and health }\end{array}$ & $\begin{array}{r}52,007 \\
5,569 \\
58 \\
57,634\end{array}$ & $\begin{array}{r}90.24 \\
9.66 \\
0.10 \\
56.68 *\end{array}$ \\
\hline Architectural & 39,621 & 38.96 & $\begin{array}{l}\text { Materials } \\
\text { Hardware } \\
\text { Fixed illumination } \\
\text { Portable illumination } \\
\text { Plumbing }\end{array}$ & $\begin{array}{r}16,404 \\
22,629 \\
39 \\
542 \\
7 \\
39,621\end{array}$ & $\begin{array}{r}41.40 \\
57.11 \\
0.10 \\
1.37 \\
0.02 \\
38.96^{*}\end{array}$ \\
\hline Furniture & 97 & 0.10 & Furnishings & 97 & $0.10^{*}$ \\
\hline Arms & 120 & 0.12 & Military defense & 120 & $0.12 *$ \\
\hline Clothing & 1,295 & 1.27 & $\begin{array}{l}\text { Clothing } \\
\text { Footware }\end{array}$ & $\begin{array}{r}1,091 \\
204 \\
1,295\end{array}$ & $\begin{array}{l}84.25 \\
15.75 \\
1.27 *\end{array}$ \\
\hline Personal & 299 & 0.29 & $\begin{array}{l}\text { Adornment } \\
\text { Body ritual/grooming } \\
\text { Pocket tools }\end{array}$ & $\begin{array}{r}130 \\
127 \\
42 \\
299\end{array}$ & $\begin{array}{r}43.48 \\
42.47 \\
14.05 \\
0.29^{*}\end{array}$ \\
\hline Activities & 2,623 & 2.58 & $\begin{array}{l}\text { Indulgences } \\
\text { Pastimes and recreation } \\
\text { Luggage } \\
\text { Household pastimes } \\
\text { Home education } \\
\text { Cleaning and maintenance } \\
\text { Vehicles } \\
\text { Maintenance } \\
\text { Agriculture and husbandry } \\
\text { Hunting } \\
\text { Fishing } \\
\text { Construction } \\
\text { Manufacturing } \\
\text { Commercial services } \\
\text { Administration } \\
\text { Education } \\
\text { Utilities }\end{array}$ & $\begin{array}{r}139 \\
520 \\
1 \\
6 \\
481 \\
371 \\
39 \\
26 \\
342 \\
385 \\
21 \\
22 \\
1 \\
111 \\
2 \\
155 \\
1 \\
2,623\end{array}$ & $\begin{array}{r}5.30 \\
19.82 \\
0.04 \\
0.23 \\
18.34 \\
14.14 \\
1.49 \\
0.99 \\
13.04 \\
14.68 \\
0.80 \\
0.84 \\
0.04 \\
4.23 \\
0.08 \\
5.91 \\
0.04 \\
2.58^{*}\end{array}$ \\
\hline
\end{tabular}


of a substantial portion of the larger and morecomplete specimens of military gear and accouterments which were to be found in refuse surrounding the fort. Military artifacts often are easily identified through their material of manufacture, largely brass or various copper alloys. Private collections made by former residents were examined when the opportunity presented itself and such collections were noted to contain substantial amounts of military material. Collecting from the fort seems to have risen to the level of a local cottage industry.

Archeological sites in North America dating from the seventeenth and eighteenth centuries have long interested archeologists. Sites from the nineteenth century initially were studied somewhat grudgingly, and sites which have twentieth-century components are still poorly appreciated. Lees and Noble (1990) observed that late-nineteenth- and early-twentieth-century sites have only recently become of interest, and central research themes have yet to be articulated. This observation has important implications for the Fort McKavett sample.

An unknown, although substantial, percentage of artifacts in the Fort McKavett sample are twentieth century in origin. During the present century, discarded materials found in modern landfills have changed. By quantity, William Rathje (1991) has estimated that present landfills are composed of 50 percent paper, 10 percent plastics, 6 percent metal, 1 percent glass, 13 percent organic material, as well as about 20 percent miscellaneous materials (construction and demolition debris, tires, textiles, rubber, and disposable diapers). Although his estimate is based on volume, it is clear that the classes of materials from pre-twentieth-century refuse dumps must have come from only 40 percent of the present volume (miscellaneous, organic, glass, and metal). The actual amount would be even smaller since organic preservation is poor when exposed to conditions more characteristic of the primary, secondary, and de facto refuse (Schiffer 1972) found on archeological sites.

Robert Friedel (1988) suggests that the last 200 years of American material culture can be divided into three periods based on the use of materials. In the eighteenth century, most fabricated materials depended on the bounty of nature. The material world was closely tied to home and farm and relied on substances like horn, bone, leather, wood, clay, and stone. In the early nineteenth century, the products of factory and forge added superior metals, high-fired ceramics, and glass. Later in the century, steam and electricity were harnessed, and rubber, aluminum, and steel fabricated. In the present century, material culture has been increasingly dependent on the synthetic plastics, composites like fiberglass, and metal alloys.

Profound changes even in the diet of the American people occurred during the nineteenth century. Quality and variety of food seem to have favored the rural consumer at the turn of the nineteenth century; by its end, the urban dweller was better fed. Canning, marketing, refrigeration, and pasteurization favored the urban consumer, while one-crop cash farming disadvantaged the farm family by the century's end. Farmers had become increasingly dependent on commercial foods but with less economic power than their urban contemporaries (Ross 1993). For consumers as a whole, however, the period between 1876 and the First World War was one of more money, and more time to spend it on more mass-produced goods that were more widely available (Schlereth 1991). The world of twentieth-century American material culture is one of abundance and consumption formerly unknown.

It has been indicated that general agreement about how to address this material culture from the standpoint of archeology is lacking. The situation from Fort McKavett highlights the confusion which often ultimately centers about the allocation of scarce research moneys and the investigator's responsibility in describing the mass-produced products of a modern industrial nation.

An important part of this problem is the issue of classification and description, a primary concern for archeological collections and essential for moreintensive study. Artifacts are customarily grouped by reference to either the material of manufacture or the original function of the artifact within the culture, if this can be inferred. An example of the former would be the classification of buttons from a collection with regard to the material from which they were manufactured, e.g., bone, shell, or metal. A functional classification, on the other hand, might classify buttons as fasteners and make them a subcategory of clothing.

For the prehistorian, the decision is more easily reached. Material of manufacture has had precedent, and much of prehistory has been interpreted through the choice of material used to fabricate tools. The very choice of terms like Stone Age, Bronze Age, and Iron Age illustrate such a perspective. The 
historical archeologist works within a cultural context that is familiar or at least known from the written record and often chooses to sort artifacts by the function they performed. The practice of classifying cultural remains by reference to the materials from which they were fashioned presents a particular set of problems when applied to artifacts from modern industrial cultures. It is, for example, unhandy to use when comparing collections from different archeological sites. An otherwise outstanding report like Herskovitz's (1978) work at Fort Bowie forces the reader who wants to know about artifacts classified as "buttons" to search for them under Metal-Accouterments, Metal-Apparel, Leather-Accouterments, Miscellaneous MaterialsBone, Miscellaneous Materials-Shell, and Miscellaneous Materials-Rubber.

Partly as a reaction to this difficulty, Roderick Sprague (1980-1981) proposed a system of classification that begins by grouping artifacts by reference to their context within the sociocultural system as follows:

I. Personal Items
II. Domestic Items
III. Architecture
IV. Personal and Domestic Transport
V. Commerce and Industry
VI. Group Services
VII. Group Ritual
VIII. Unknowns

These headings are further subdivided. The subclasses which follow were recognized in the collection from Fort McKavett, and an example of an artifact which might be found in each class is given in parentheses (see Appendix $\mathrm{C}$ for a more detailed description):

\section{Personal Items}

Clothing (button)

Footwear (shoelace)

Adornment (bracelet)

Body Ritual (cosmetics)

Medical (pharmaceutical bottle)

Indulgences (smoking pipe)

Pastimes (toy marble)

Ritual (Bible)

Pocket Tools (pocketknife)

Infant Care (baby bottle)

Luggage (suitcase)
II. Domestic Items

Furnishing (curtain rod)

Culinary-Food Preparation-Glass (jug)

Culinary-Other (stoneware vessel)

Gustatory-Food Consumption (earthenware vessel)

Portable Illumination (lamp chimney glass)

Household Pastimes (magazine)

Home Education (slate board)

Cleaning and Maintenance (broom)

III. Architecture

Materials (window glass)

Hardware (nail)

Plumbing (faucet)

Fixed Illumination (electrical insulator)

IV. Transport

Vehicle (wagon spoke)

Maintenance (wrench)

V. Commerce and Industry

Agriculture and Husbandry (fence staple)

Hunting (civilian cartridge)

Fishing (lead sinker)

Construction (hammer)

Manufacturing (rivet)

Commercial services (coin)

VI. Group Services

Administration (license plate)

Public Safety (military cartridge)

Education (pen nib)

Utilities (telephone)

VII. Group Ritual

VIII. Unknowns

Metal

Glass

Ceramic

Bone

Ethno-organic

Lithic

Plastic and Rubber

The last category, Unknowns, seemingly slips back into the realm of description by material of manufacture. In fact, it is an example of the pragmatism to which Sprague adhered and a bookkeeping necessity for tiny fragments of material culture that find their way into collection bags from excavations. Artifacts are often recovered which by virtue of their small size and/or fragmentary nature are ambiguous with regard to function. A tiny sherd of glass could have come from a prescription medicine bottle (Personal Items-Medical), a water 
jug (Domestic Items-Culinary), or even a washboard (Domestic Items-Cleaning and Maintenance). In such cases, probable identification is encouraged by Sprague, if possible (1980-1981:258). The category Unknowns is not discussed further here although it is retained in the "laundry list" of data encoded by the Sprague classification from Fort McKavett and included with this section of the report.

The late 1960s and 1970s saw the high-water mark of the nomothetic approach in archeology (the scientific search for general or covering laws). A necessary condition for this approach was the quantification of data which could be used in comparisons between archeological sites and to discern patterns in the data from particular sites which might lead to explanations of behavior within the cultural system. Briefly, such a methodology entailed examining the quantified data set for patterns; developing lawlike generalities from these observations; subjecting such observations to logical analysis to determine consequences; forming hypothesizes based on such consequences; and, finally, testing hypotheses against other data.

With historical collections, the utility of a functional approach to classification was evident. The functionalist approach to the study of culture was a keystone of the "new archeology," although within anthropology, it had been a recognized methodology for some time. Its basic assumption is that basic human needs are relatively few in number. In the functionalism of Malinowski (1939), these needs were stated as: nutrition, reproduction, bodily comforts, safety, relaxation, movement, and growth. Stanley South, one of the most influential "new archeologists," translated these needs into material culture of eighteenth- and early nineteenth-century America by a ninefold classification of artifacts into principal groups:

Kitchen Artifact Group (e.g.,
Malinowski's nutrition)
Bone Group
Architectural Group
Furniture Group
Arms Group
Clothing Group
Personal Group
Tobacco Pipe Group
Activities Group

Within these groups South recognized some 42 classes of artifacts, such as ceramics and window glass. The classification of an individual artifact was further specified with reference to class, material, and type. An example of this hierarchical scheme would be Kitchen Group: Class-ceramics: Material-earthenware: Ware-pearlware: Type-blue painted pearlware (South 1977:93). No allowance for more-recent materials, like electrical fixtures, was provided since his classification was designed for sites predating the Civil War.

Although South's paradigm has many similarities with Sprague's, it is fundamentally theoretical rather than pragmatic. Its real purpose is to transcend ordinary description and search for general laws in the patterns observable in carefully controlled, quantified artifact assemblages. Both systems are functionalist in orientation although they do not start with the same categories. Both schemes also share the initial assumption that the original function of the artifact within its sociocultural context can be inferred. These similarities make it possible to compare the artifact sample from Fort McKavett, encoded with Sprague's classification, with the more theoretically minded one of South. Finding the correspondence between the two classifications at a general level such as that of the Artifact Group/Item is fairly straightforward (see Table 10).

All artifacts not classified as Unknowns in the Sprague system of encoding, including those that make up the body of the present report, are included in Table 10. South's Groups are intact in the left column, while Sprague's categories are merged at the next more specific level below Items. These have been reordered in the right column. A few of Sprague's categories are arguably placed. Artifacts associated with medicine and health are found under the Kitchen Artifact Group because original function in the case of this category is often inferred from fragmentary specimens of glass that are probably medical in function. Cobalt glass is such an example. Regardless, the size of the category is so tiny that it has little opportunity to express itself in a sample of the magnitude of Fort McKavett. Likewise both "portable" and "fixed illumination" find themselves in Architecture Group. Fixed illumination is probably temporally significant and certainly includes such items as light bulb fragments. Portable illumination usually refers to lamp chimney or body fragments from oil lamps. These are often less temporally diagnostic although differences can be recognized between nineteenth- and twentieth-century 
examples. Neither class is easily confused with culinary or gustatory artifacts, and "illumination" seems to fit best in Architecture.

The category Activities Group has an unfortunate sort of catch-all feel, although it is defensible by the criteria of consistency. An added benefit when using Sprague's system is that the classes of material that fall within South's Activities Group pervue are easily broken out and become the stuff of aberrations in artifact ratios. Such aberrations are actively sought because they are believed to point toward activities and behavior. The area used by a farrier may be discovered through horseshoe nails; a structure used as a schoolroom may be found by slate fragments.

One aspect of the McKavett collection that is certainly underrepresented is military artifacts (military defense). Both observation and anecdotal evidence about how easily military artifacts are found seem to be borne out by the numbers. The problem of artifacts that may have come from a military context but which have lost that context has been mentioned earlier, and it is not an area of inquiry that has promise of improvement with a closer look for reasons stated earlier-diagnostic criteria for the suspect classes (earthenware, glass body sherds) are absent and local archeological deposits relatively unstratified.

At this comparative level, the standard questions of "what is it and where did it come from?" are not answerable. Both can be approached only from the level of the individual artifact, a level of analysis not attempted in this study. South suggested that "It is expected that broader cultural processes will likely be revealed at the group level of generalization due to the functional relationship between the group and generalized behavioral activity in the cultural system." In other words, if the sample can be quantified by functional (activity) groups, the resulting ratios between artifact groups might be useful for describing behavior as well as making comparisons with other samples.

South also believed that cultural process should be studied using a systems approach (another keystone of the "new archeology"). This posits a relationship between the behavioral by-products (artifacts) of the individual household and the larger cultural system. The larger cultural system, he felt, imposes limits on behavior that will be reflected in cultural patterns like refuse disposal. Emphasizing quantitative and comparative aspects of this relation- ship, he sought to examine "the ratios between artifact groups with the view of establishing certain broad regularities or pulsations of culture process against which any deviation from such regularities can be contrasted as reflecting behavior somewhat different from expected margins" (South 1977:86).

The data base chosen by South to test these ideas came from five excavated sites of British colonial origin in the Eastern United States. The sites spanned the period A.D. 1732 to 1820 . Most were excavated by South himself. The sites were a six-room foundation for an inn/tailor shop (all artifacts used in analysis); a two-room foundation residence/refuse dump (all artifacts used); two midden deposits from a military fort (artifacts from exploratory trenches used); and a single-room cellar/secondary midden (all artifacts used). After adjusting for specialized activities which occurred at particular sites (the tailor shop site produced a skewed sample of clothing-related items out of the range of other sites), the results were expressed as a percent of the range for all five sites and as a mean within that range. The resulting ratios were recognized as the Carolina Artifact Pattern (Table 11).

To see if the pattern appeared to have spatial and temporal implications, it was compared with data from two additional British colonial sites at Signal Hill, Newfoundland, which were occupied until A.D. 1860. The deviation in range between the Carolina Pattern and the Newfoundland sites was statistically insignificant suggesting a good fit and possible predictive value for the pattern, at least on British colonial sites (see Table 11).

The potential for differences between British colonial sites that were occupied before A.D. 1860 and those of the following 100 years is difficult to overstate. The historian John Lukacs (1984:170) believes that the home and its domestic artifacts from the year 1930, although still familiar to us today, would have been unrecognizable to a person from 1885 so great were the changes in domestic material culture in that short 45 years.

A substantial portion of the artifacts from Fort McKavett must fall into that gap. Without any generally agreed upon paradigm to take from the shelf and use with late-nineteenth and early-to-midtwentieth-century cultural materials, it was determined to compare Sprague's classificatory scheme, which was used to encode the McKavett artifacts, with South's more-theoretical ideas about artifact 
TABLE 11

COMPARISON OF COLLECTIONS USING SOUTH'S FUNCTIONAL CLASSES

\begin{tabular}{|l|c|c|c|c|c|c|}
\hline & \multicolumn{2}{|c|}{$\begin{array}{c}\text { The Carolina Artifact Pattern } \\
\mathrm{n}=84,580\end{array}$} & $\begin{array}{c}\text { Signal Hill } \\
\mathrm{n}=14,188\end{array}$ & $\begin{array}{c}\text { Fort McKavett } \\
\mathrm{n}=101,689\end{array}$ & $\begin{array}{c}\text { Fort Richardson } \\
\mathrm{n}=15,350\end{array}$ & $\begin{array}{c}\text { Fanthorp Inn } \\
\mathrm{n}=24,965\end{array}$ \\
\cline { 2 - 7 } South's Groups & Mean \% & $\%$ Range & $\%$ & $\%$ & $\%$ & $\%$ \\
\hline Kitchen & $51.8-69.2$ & 63.10 & 57.20 & 58.68 & 58.51 & 64.61 \\
Architecture & $19.7-31.4$ & 25.50 & 25.80 & 38.96 & 38.80 & 27.65 \\
Furniture & $0.1-0.6$ & 0.20 & 0.00 & 0.10 & 0.40 & 0.08 \\
Arms & $0.1-1.2$ & 0.50 & 0.20 & 0.12 & 0.57 & 0.00 \\
Clothing & $0.6-5.4$ & 3.00 & 2.60 & 1.27 & 0.47 & 1.23 \\
Personal & $0.1-0.5$ & 0.20 & 0.10 & 0.29 & 0.32 & 0.42 \\
Tobacco Pipes & $1.8-13.9$ & 5.80 & 11.10 & $*$ & $*$ & $*$ \\
Activities & $0.9-2.7$ & 1.70 & 2.90 & 2.58 & 0.93 & 6.01 \\
\hline *Group not used
\end{tabular}

ratios. The potential merits of this marriage are that it allows us to extend the temporal range of South's paradigm from 1860 until 1970 while at the same time pushing such an analogy to a seemingly absurd level in a test of fire. What could the averaged artifact ratios from a group of sites technologically belonging to the early to mid industrial revolution have to do with a post-Civil War frontier military site in the Texas Hill Country and its civilian progeny?

The Fort McKavett sample is only one example of a nineteenth-century site that was classified using Sprague's system. A consistent approach to artifact curation and encoding by the Historic Sites and Restoration Branch provides other collections that are also useful in this regard. Fort Richardson in Jacks County overlaps the occupation at McKavett and was similar in many ways. Like Fort McKavett, its usefulness as a frontier post was limited in duration, but a small city grew up around the abandoned fort. Fort Richardson's buildings did not fare nearly as well as contemporary ones at McKavett and only one officers' quarters survived as a residence. Acquisition by TPWD resulted in a restoration program that oversaw the rebuilding of a number of the fort's officers' quarters and barracks during the 1970s and 1980s (Black and Kegley 1995).

Fanthorp Inn (Ing and Hart 1987) temporally links South's sites with the Texas collections since its occupation dates from the 1830s. When acquired by TPWD in 1977, the principal structure had been in continuous family ownership for 143 years. Excavations at Fanthorp Inn were conducted to provide clearance for a parking lot, search for dependencies, and provide architectural delineation for missing parts of the original structure. The collection, steadfastly civilian, should provide a useful foil for the mixed military and civilian collections from Fort McKavett and Fort Richardson.

The three Texas sites also have important similarities aside from the more abstract notion of an unspecified relationship to the Carolina Pattern. All were excavated under the same general mission - an approach oriented to architectural delineation by the same agency and with many of the same personnel. A certain consistency in execution, and perhaps in sampling, is evident. The case for attaching significance to ratios among classes of artifacts has evident surface appeal among such sites occupied during the same period and excavated with similar method and purpose by the same people.

The extent of agreement between artifact ratios at the two Texas military forts, McKavett and Richardson, after conversion to South's classification are surprising (see Table 11). The largest numerical groupings, accounting for 96 percent of all artifacts excavated from each site (the Kitchen and Architectural Groups) fall within one percentage point of one another. Both also fall out of range with South's Carolina Pattern with regard to the Architecture Group. It would come as no surprise to an historical archeologist familiar with nineteenthcentury material culture that one of the clearest differences between sites from early and late in this century are changes in building hardware, particularly the rising numbers of the mass-produced cut 
nails (Edwards and Wells 1993). The other major category subsumed under Architectural Group is flat or window glass, another growth industry in the nineteenth century.

The ratios of the same categories differ significantly between the forts and Fanthorp Inn. However, the differences between Fanthorp Inn and South's Carolina Pattern are few. In fact, the only category from the inn which falls out of range with the mean of the Carolina Pattern is Activities. If South's Tobacco Pipes Group had been combined with the Sprague category "indulgences," the correspondence between the Fanthorp and the Carolina Pattern would have been close indeed. The Tobacco Pipes Group was not converted because South had a very specific category of temporarily diagnostic artifacts in mind that are not present in late-nineteenth- and early-twentieth-centuryassemblages. The function "indulgences" remains a perfectly viable category in the Sprague classification and would include tobacco pipes as well as other smoking paraphernalia.

An example of what South intended to do with aberrations in intersite ratios can be shown by using the Activities Group from Fanthorp Inn. It is the most interesting out-of-range ratio between the Fanthorp sample and the Carolina Pattern. Aberrations are often especially revealing for specialized activities such as crafts or trades that may be present in the archeological record but missing from documentary sources. The Sprague system is particularly well equipped to expeditiously locate the source of such aberrations even in large collections where the forest can obscure the trees.

The Activities Group from Fanthorp contains 6.01 percent of the sample ( $n=1,550$ artifacts). This can be broken down easily to show that the universe, Activities Group, is comprised of 29.6 percent "pastimes" which are really musical devices, game pieces (especially marbles), toys, and doll parts; 18.2 percent "home education" comprised of slate and pencil fragments; 15.9 percent "agriculture and husbandry" which are fencing staples and rivets; 10.6 percent "yard maintenance" or flower pots, hose fittings, and faucet parts; and 9.9 percent "hunting" reflected by civilian cartridge cases and shot. The remaining 15.8 percent consists of several small categories that are not listed. While this is not an unusual range of materials, it does suggest children, literacy, gender, the use of wire fencing, landscaping, and hunting.
Historical archeologists have traditionally expended much energy explaining how their work elucidates the documentary record. The possibility of developing paradigms that free archeologists to quantify their data and compare it between sites at a higher level of explanation is seductive. On its surface, the relationships shown between the ratios of functionally defined classes of artifacts would appear to be an embarrassment of riches in this regard. More likely it is a chimera.

What does a measure of agreement or consistency in the functional ratios of artifacts between archeological sites that are separated by space, time, and sampling methodologies really mean? It will not be argued that similar ratios stem from general laws covering human behavior. The notion that agreement among ratios somehow reveals behavioral patterns is suspicious in the collections examined, for, if this were the case, assumptions would have to be made that the sampling methodology that resulted in the collection of the data was controlled. Otherwise, the results would seem statistically meaningless and its truth unfathomable. South attempted to control this bias by complete excavation, if possible. In the three sites examined from Texas, sampling was neither random nor complete, focusing as it did upon architectural delineation. In some cases, whole rooms or features were excavated; more often, wall lines were traced and the interior of buildings briefly tested; at other times these depostis were undisturbed. Areas exterior to structures also were tested but with coverage that varied widely. The notion that this sort of sampling, even if productive of a large data base, as at Fort McKavett, could somehow produce representative ratios cannot be supported on its face. The method is not a panacea that can be broadly or universally applied without regard to methodological variables; South never intended it as such.

While much is made about the seeming pitfalls of positivism as a form of worship in archeology, coincidences in artifact ratios that transcend time and space are a phenomenon when employing South's system. An obvious place to begin looking for explanations is with the relationship between the classificatory system and the data base. It might be the argued that the initial categories are so rough that an outcome that appears to suggest correspondence is really predetermined and illusionary.

In spite of recognition that these approaches have passed their peak of popularity within the 
profession, they are not without power to increase our understanding of the material cultures of the post-industrial revolution. Their usefulness in modern material studies may stop short of the anticipated discovery of general or covering laws which have attracted substantial post-processual criticism (Shackel and Little 1992), but the classification of large collections and the use of rough quantitative analysis remains the necessary first and, perhaps, middle step in the study of large artifact samples. The most positive results seem to accrue from providing an alternative to labor-intensive descriptions of modern collections which are mixed, largely without visible stratigraphy, and characterized by large numbers of individual specimens that are not temporally diagnostic. The technique also shows promise at the level of pattern recognition in the search for spatial significance and areas where specialized activities took place.

In the theory of classification, a distinction is often made between "rough" and "fine" classifica- tion. Although not always an easy or useful distinction, it is sometimes made between applied and pure sciences. A more useful way of looking with regard to archeological purposes would seem to be toward the purpose of the classification. If it is simply to make information available, a practical or pragmatic approach may have precedence over a theoretical one. It is on this level that the systems of Sprague and South are most clearly distinguished. Sprague will count your beans and let you have a general notion of the character of the collection. South, under carefully controlled conditions that are often outside the realm of possibility in most applied research, promises a glimpse at beanness.

The comparisons offered in this appendix treat the Fort McKavett collection as a whole. For those researchers interested in particular proveniences, copies of tables showing artifacts classified according to the Sprague system and listed by minimum provenience are on file at TPWD and Prewitt and Associates, Inc. These data will be provided on request. 


\section{REFERENCES CITED}

Black, A., and G. Kegley

1995 Fort Richardson State Historical Park, Jack County, Texas: Archeological Testing and Recording, 1978, 1979, 1981, 1985, 1986. Draft report submitted to the Department of Antiquities Protection by the Texas Parks and Wildlife Department, Public Lands Division, Cultural Resources Program, Austin.

Edwards, J., and T. Wells

1993 Historic Louisiana Nails: Aids to the Dating of Old Buildings. Monograph Series No. 2. Department of Geography and Anthropology, Louisiana State University, Baton Rouge.

Friedel, R.

1988 A Material World: An Exhibition at the National Museum of American History. Smithsonian Institution, Washington, D.C.

Herskovitz, R.

1978 Fort Bowie Material Culture. The University of Arizona Press, Tucson.

Ing, D., and J. Hart

1982 Archeological Excavations at Fanthorp Inn State Historic Site (4IGM79), Grimes County, Texas. Texas Parks and Wildlife Department, Historic Sites and Restoration Branch. Austin.

Lees, W., and V. Noble

1990 Other Questions That Count: Introductory Comments on Assessing Significance in Historical Archaeology. Historical Archaeology 24(2): 11.

Lukacs, J.

1984 Outgrowing Democracy: A History of the United States in the Twentieth Century. Double Day, Garden City, New York.
Malinowski, B.

1939 The Group and the Individual in Functional Analysis. American Journal of Sociology (44): 938-964.

Rathje, W.

1991 Once and Future Landfills. National Geographic 179 (May).

Ross, A.

1993 Health and Diet in 19th Century America. Historic Archaeology 27(2):42-51.

Schiffer, M.

1972 Archaeological Context and Systemic Context. American Antiquity 37:156-165.

Schlereth, T.

1991 Victorian America: Transformations in Everday Life, 1876-1915. Harper Collins, New York.

Shackel, P., and B. Little

1992 Post-Processual Approaches to Meaning and Uses of Material Culture in Historical Archaeology. Historical Archaeology 26(3):5-11.

South, S.

1977 Method and Theory in Historical Archeology. Academic Press, New York.

Sprague, R.

1980 - A Functional Classification for Artifacts from 1981 19th and 20th Century Historical Sites. North American Archaeologist 2(3). Baywood Publishing, Farmingdale, New York.

Swannock, J.

1975 Mission-Oriented Agencies: Means and Ends of Historic Sites Archaeology. Historical Archaeology 9:81-82. 


\section{APPENDIX C: The Sprague Code Functional Artifact Classification as Modified by the Texas Parks and Wildlife Department}

George Kegley

Texas Parks and Wildlife Department Austin, Texas 
Sprague's classification system was modified by the Historic Sites and Restoration Branch archeological laboratory in a number of ways, most commonly by the use of additions to artifact categories. Categories which were added to or otherwise modified for use by the laboratory are identified by the use of a symbol $(\checkmark)$. Some artifact types may occur in more than one category, and their placements depend on the particular context in which they were found.

\section{Personal Items}

\section{A. Clothing}

1. Fasteners $\checkmark$ : The category "fasteners" may contain items identified as zippers, suspender loops, snaps/rivets, grommets, studs, belt buckles, studs for collar and cuff, as well as miscellaneous fasteners.

2. Buttons $\checkmark$ : The category "buttons" may contain buttons manufactured from ferrous, cuprous/brass, white metal, china, glass, bone, shell, hard rubber, plastic, composition, or miscellaneous materials. On military sites, the use of buttons may transcend function and be a symbol of group identity. For this reason, military buttons are found under Group ServicesPersonal Safety-Military Defense. Personal Items-Footwear also contains a specialized class of buttons.

3. Outer Garments $\checkmark$ : "Outer Garments" refers to items of clothing like coats, blazers. sweaters, raingear, etc. Within this category, fabric and hardware are recognized.

4. Fabric $\checkmark$ : The only recognized subclassification is "unidentified."

5. Hats $\checkmark$ : The category "hats" has no recognized subcategories.

6. Clothing $\checkmark$. "Clothing" refers to personal garments like shirts, dresses, jeans, slacks, neckties. Within this category, fabric and hardware are recognized.

7. Under Garments $\checkmark$ : "Under garments" refers to items of personal clothing like socks, stockings, garters, corsets, etc., which are worn close to the skin. Within this category fabric, hardware, such as slide buckles for brassieres or corsets are recognized as well as miscellaneous items.

8. Accessories $\checkmark$ : The category "accessories" includes purses, gloves, and belts, as well as miscellaneous items like parts of an umbrella or a bow tie clip.

9. Notions $\checkmark$ : This category contains safety pins and hook-and-eye fastening devices. Hook-and-eye devices intended for use on military garments would be found under Group ServicesPublic Safety-Military Defense.

B. Footwear

1. Grommet $\checkmark$ : No subcategories are recognized.

2. Shoe Parts $\checkmark$ : The shoe is divided into upper (leather, cloth, or vinyl) components; sole (leather, cloth, vinyl, plastic, or rubber), and heel (leather, cloth, or vinyl). Other shoe parts like shoe tacks are classified as miscellaneous.

3. Button $\checkmark$ : This category is restricted to a single type of highly specialized button.

4. Laces $\checkmark$ : "Tips" are recognized under this category.

5. Screws $\checkmark$ : Shoe screws are a distinctive, temporally diagnostic artifact invented in the nineteenth century.

6. Miscellaneous $\checkmark$ : This category includes footwear-related items like shoe horns and spurs.

C. Adornment

1. Jewelry $\checkmark$ : Within this category, items like rings, tie tacks, and miscellaneous items like hat pins or earrings are recognized.

2. Beads $\checkmark$ : "Beads" are classified as glass or miscellaneous.

D. Body Ritual and Grooming

1. Teeth $\checkmark$ : This category contains toothbrushes, toothpaste/powder containers, dentures or partial plates, dental floss, and miscellaneous items like toothpicks.

2. Hair $\checkmark$ : Items associated with hair care include brushes; combs; accessories like hair pins, combs, and barrettes; grooming aids like hair spray or 
cream; and miscellaneous items like hair curlers.

3. Body $\checkmark$ : Grooming aids make up this category and include supplies like soap and lotion and tools like razors and emery cloths. A miscellaneous item from this category might be, for example, a bandaid.

4. Cosmetics $\checkmark$ : Cosmetics include makeup, tools like tweezers, and miscellaneous items like perfume bottles.

E. Medical

1. Bottles $\checkmark$ : "Bottles" has no subcategories and refers to containers that were used for patent and prescription medicine.

2. Eyeglasses $\checkmark$ : "Eyeglasses" has no subcategories.

3. Equipment $\checkmark$ : Items in this category refer to medical equipment like crutches, canes, thermometers, etc.

4. Invalid Care $\checkmark$ : Bedpans and miscellaneous related items are recognized in this category.

5. Miscellaneous $\checkmark$ : Examples are items such as pill boxes or nasal inhalers.

F. Birth Control

1. Female $\checkmark$ : Anticipated items in this category are diaphragm springs, pill cases for birth control medications, spermicide tubes, and other related miscellaneous items.

2. Male $\checkmark$ : Items anticipated from this category are condoms and related miscellaneous items.

G. Indulgences

1. Liquor $\checkmark$ : Cans, bottles, and miscellaneous containers for alcoholic drinks comprise this category.

2. Smoking $\checkmark$ : Items associated with the use of smoking tobacco such as cigarette or cigar remains, pipes and tools associated with their use, and accessories like lighters, ash trays and miscellaneous related items are found here. Matches, although clearly used as an aid to smoking tobacco, are found under Domestic Items-Housewares and Appliances-Portable Illumination.

3. Gambling $\checkmark$ : Cards, dice, poker chips, and related miscellaneous items comprise this category.

4. Drugs $\checkmark$ : Recreational drugs and paraphernalia are classified under this category.

5. Non-smoked Tobacco $\checkmark$ : Varieties of nonsmoked tobacco like snuff and chewing tobacco are recognized, as well as accessories like spittoons and miscellaneous related items.

6. Confections $\checkmark$ : Candy and chewing gum may be recognized by their commercial wrappers.

H. Pastimes and Recreation

1. Toys $\checkmark$ : Dolls, children's diversions, and miscellaneous related items are included in this category.

2. Games $\checkmark$ : Marbles (glass, clay/porcelain, stone, and miscellaneous materials) as well as jacks, gaming pieces, and miscellaneous related items are found here.

3. Music $\checkmark$ : The harmonica, Jew's harp, other reed instruments, sheet music, accessories for musical instruments like the capo, and related items like phonograph records and cassette tapes are recognized in this category.

4. Art $\checkmark$ : Supplies, including those associated with photography, and items like crayons, brushes, and plaster of paris are included as well as works of art, art books, and miscellaneous related items.

5. Crafts and Hobbies $\checkmark$ : Supplies and tools, works so created, instructional books, and miscellaneous related items are assigned to this category.

6. Sports $\checkmark$ : Sports equipment and miscellaneous related items are found here.

7. Camping $\checkmark$ : This category has no subclassifications.

I. Ritual

1. Religious $\checkmark$ : Items in this category include the icons of religions, like the Christian cross, sacred texts, and miscellaneous related items.

2. Trophy $\checkmark$ : This category has no subclassifications.

3. Fraternal $\checkmark$ : In this category are pins, jewelry, and paraphernalia as well as 
miscellaneous related items.

4. Boy Scout/Girl Scout $\checkmark$ : This category has no subclassifications.

J. Pocket Tools and Accessories

1. Keys $\checkmark$ : This category may include padlocks, skeleton keys, furniture associated with locks and keys, car keys, and miscellaneous related items.

2. Knife $\checkmark$ : This category is intended for pocketknives.

3. Wallet $\checkmark$ : This category has no subclassifications.

4. Charms $\checkmark$ : Special coins, medallions, or items like a rabbit's foot as well as miscellaneous items are included in this category.

5. Watch $\checkmark$ : This category has no subclassifications.

K. Infant Care

1. Feeding $\checkmark$ : This category consists of baby bottles and parts, pacifiers or teething rings, utensils, and dishes.

2. Clothing $\checkmark$ : This category consists of diaper pins and garments such as diapers and bibs.

3. Play $\checkmark$ : In this category are swings, buggies or strollers, toys or rattles, and other miscellaneous related items.

4. Care $\checkmark$ : In this category are baby powder containers, ointment tubes, and miscellaneous related items.

L. Luggage

1. Suitcase $\checkmark$ : A category intended for associated hardware and miscellaneous related items. Keys associated with these items would be found under Pocket Tools-Keys.

2. Briefcase $\checkmark$ : A category intended for associated hardware and miscellaneous related items. Keys associated with these items would be found under Pocket Tools-Keys.

3. Trunk $\checkmark$ : A category intended for associated hardware and miscellaneous related items. Keys associated with these items would be found under Pocket Tools-Keys.

\section{Domestic Items}

\section{A. Furnishings}

1. Furniture: Hardware items associated with furniture like upholstery tacks, hinges, escutcheons, and bed parts as well as objects of furniture like chairs are included here.

2. Drapery: Cloth and hardware employed for this purpose are found in this category.

3. Decorative: Items intended for decorative purposes, e.g., knickknacks, family photographs, pressed glass, mirrors, and clocks are included in this category.

4. Wall Coverings $\checkmark$ : Wallpaper, canvas, and related items make up this category.

5. Floor Coverings $\checkmark$ : This category has no subclassifications.

B. Housewares and Appliances

1. Culinary: Items used in food preparation may include ceramics, glass, utensils, cookware (e.g., cast iron pots, granitewares, canning jar lids, and tin foil) as well as tin cans, stoves, refrigerators, and miscellaneous related items.

2. Gustatory: Items used in food consumption include ceramics (earthenware, porcelain, and others), glass tablewares, utensils, serving dishes, condiment containers (e.g., catsup), and items associated with nonalcoholic beverages (crown caps, pull tabs, soda bottles) as well as miscellaneous related items like plastic straws and cork screws.

3. Portable Illumination: The items in this category are intended for lighting such as oil lamps (chimney glass and parts), flashlights and batteries, candles (sticks and holders), and fire starters (matches). See also Architecture-Fixed Illumination.

4. Portable Waste Disposal and Sanitation: Chamber pots and washbasins are included as well as wastepaper baskets, trash compactors, and related items.

5. Portable Heating, Cooling, and Atmospheric Conditioning: Fans, heaters (bed, hand, foot warmers), humidifiers and dehumidifiers, air conditioners, and 
miscellaneous related items are found here.

6. Domestic Ritual: This category has no subclassifications.

7. Household Pastimes: This category is used for books and is distinguished from Personal Items-Games; Music; Toys; Crafts and Hobbies. See also Home Education (below).

8. Home Education: Lead and slate pencils, ink pens and their parts, slate boards, desk accessories (staples, paper clips, rubber bands, etc.), clocks, calendars, books, ink bottles, and miscellaneous related items comprise this category. Books found here are presumably not recreational in nature. Group Services-Education-Schoolalso contains books.

C. Cleaning and Maintenance

1. Cleaning: Items in this category are containers for cleaning chemicals and tools associated with cleaning (e.g., brooms, mops) as well as miscellaneous related items.

2. Household Maintenance: Items used in common home repair like hammers, screwdrivers, and miscellaneous related items are found here. See also Commerce and Industry-Construction.

3. Laundry: Pressing irons, clothespins, washboards, and miscellaneous related items like clothes hangers are found here.

4. Sewing: Pins (dressmaker's), needles, scissors, thimbles, mechanical sewing machines and their parts, and miscellaneous related items like thread, spools, and crochet hooks make up this category.

5. Pest Control: Household pest control devices like mousetraps, fly swatters, flypaper, and miscellaneous related items comprise this category.

6. Yard Maintenance and Decoration: Tools like rakes, hoes, shovels, hand tools, wheelbarrows, lawnmowers, water hoses, and axes are found here. The category also contains items like flower pots and miscellaneous related items. Similar tools and items may be found in Household Maintenance (above).

7. Pet Maintenance: Included are items like leashes and collars, food bowls, pooper-scoopers, and miscellaneous related items like pet brushes, toys, health care, fish tank gravel, etc.

8. Domestic Safety: Items included are fire extinguishers, fire grenades, and fire bells, as well as security devices like padlocks and miscellaneous related items. Note that locks can also appear under Architecture-Hardware and Domestic Items-Furniture-Furnishings.

\section{Architecture}

A. Structures (structures may include houses and outbuildings)

B. Construction

1. Materials: This large category includes architectural/building-relateditems like wood, window glass, paint, cement, mortar, plaster, rock, shingles, tarpaper, adobe, brick, and miscellaneous related items like asbestos siding, linoleum, caulk, and putty.

2. Hardware: Included are nails (cut and wire, whole and fragmentary specimens), wood screws, door hardware (hinges, knobs, rim locks, escutcheons, padlocks, and miscellaneous related items), tacks, window hardware (locks, pulley and weights, glaziers points, and miscellaneous related items like window screen), staples (other than fencing, see Agriculture and HusbandryStabling Activities, below), wire, and miscellaneous related items like corrugated joint fasteners, lathe, nuts and bolts, washers, spikes, rivets, and burrs.

C. Plumbing

1. Water Supply: Included in this category are items like pumps,-pipes, heaters, and miscellaneous, related items.

2. Sanitation: Waste pipes, septic tanks, and miscellaneous related items associated with the waste system are included here.

3. Fixtures $\checkmark$ : Items in this category are 
bathtub/shower parts, sinks and garbage disposals, toilet parts, and miscellaneous related items.

D. Fixed Illumination and Power

1. Gas $\checkmark$ : Pipes, fixtures, and miscellaneous related items are included.

2. Electrical $\checkmark$ : The hardware of electricity delivery, wire, insulation/insulators, fixtures, fuses, light bulbs, and miscellaneous related items form this category.

3. Wind $\checkmark$ : Windmill parts comprise this category.

E. Fixed Heating: Furnaces, air coolers, ceiling fans, and miscellaneous related items are found here.

F. Conveyances: A dumbwaiter category is recognized.

G. Private Communications: Intercoms and telephones make up this category.

H. Architectural Safety: This category recognizes fire escapes, lightening rods, and miscellaneous related items.

I. Landscaping: This category is used for constructions like rock walls and miscellaneous related items.

\section{Personal and Domestic Transport}

\section{A. Vehicles}

1. Parts $\checkmark$ : Items from wagons, automobiles, motorcycles, and bicycles are recognized. Also see Commerce and Industry-Agriculture and HusbandryFarm Equipment.

2. Accessories $\checkmark$ : Automobile floormats are an example of this category.

B. Maintenance

1. Tools $\checkmark$ : Wrenches, screwdrivers, jacks, tire irons, and miscellaneous related items are found here. Note that such items as screwdrivers can also be found under Domestic ItemsHousehold Maintenance.

2. Supplies $\checkmark$ : Fluids associated with vehicles like gas, oil, antifreeze, and grease as well as miscellaneous related items like filters make up this category.

C. Ritual: Such items as religious icons, baby shoes, foam dice, and graduation tassels are intended for this category.
D. Road and Rail $\checkmark$ : Asphalt, railroad ties, and road gravel are included in this category.

\section{Commerce and Industry}

\section{A. Agriculture and Husbandry}

1. Farm Equipment $\checkmark$ : This classification includes items such as plows, tractors, wagons, balers, and miscellaneous related items.

2. Stabling Activities $\checkmark$. In this category are wire, fencing staples, fencing, barbed wire, gates, posts, and miscellaneous related items.

3. Harness Equipment $\checkmark$ : Included in this category are buckles, rivets, hardware, leather, and miscellaneous related items like bits and saddles.

4. Animal Related $\checkmark$ : Items here are shoes (horse, mule), shoe nails, rasps, bells, and miscellaneous related items.

5. Miscellaneous $\checkmark$ : This category has no subclassifications.

B. Hunting: Although the distinction cannot always be made, items in this category are considered civilian rather than military in use. Military arms and ammunition are found in Group Services-Public SafetyMilitary Defense. The distinction at military posts where soldiers are known to have hunted would be contextual in principal and often impossible to determine in practice.

1. Rifle $\checkmark$ : This category is intended for cartridges, bullets, and percussion caps, gun parts, cleaning equipment, reloading equipment, and gun flints.

2. Shotgun $\checkmark$ : This category is intended for shells and shot, gun parts, and cleaning and reloading equipment.

3. Pistol $\checkmark$ : Cartridges and bullets as well as gun parts are recognized in this category.

4. Accessories $\checkmark$ : Clothing, deer stands, game calls, gun powder, tanning supplies, and related miscellaneous items such as lead sprues comprise this category.

5. Miscellaneous: This category has no subclassifications. 


\section{Fishing}

1. Pole Equipment $\checkmark$ : Rods, reels, fishing lines, lures and weights, hooks, and related miscellaneous items comprise this category.

2. Miscellaneous Equipment $\checkmark$ : Such items as stringers, nets, bait boxes, tackle boxes, and related miscellaneous items comprise this category.

D. Gathering

1. Baskets $\checkmark$ : This category has no subclassifications.

2. Nets $\checkmark$ : This category has no subclassifications.

E. Trapping

1. Traps $\checkmark$ : This category has no subclassifications.

F. Logging: This category has no subclassifications.

G. Mining and Quarrying: This category has no subclassifications.

H. Construction

1. Architecture: This category involves construction of buildings and includes such tools as tape measures, hammers, saws, wrenches, files, pliers, and related miscellaneous items. See also Architecture-Constructionand Domestic Items-Household Maintenance.

2. Transportation: This category involves construction of railroads and includes railroad spikes and related miscellaneous items.

3. Utilities: This category involves construction of utilities and related miscellaneous items.

I. Manufacturing

1. Handicraft: These items are intended for resale and include tools and hardware associated with such activities and related miscellaneous items.

2. Industrial: Items associated with the tools and machines of industry including their parts, like print or type for the printing process.

J. Commercial Services

1. Food, Drink, and Lodging: This category is intended to include hotel, restaurant, and bar items.

2. Grooming: Commercial items associated with barber shops and beauty parlors are found here.

3. Jurisprudence: Books and papers associated with legal transactions are included here.

4. Monetary: Banks and their products like coins, paper money, and related miscellaneous items such as cash register receipts and checks are found here.

5. Repair and Maintenance: No subcategories are recognized here.

6. Medical: Items associated with doctor's offices, pharmacies, and related miscellaneous items are included here.

7. Animal Care and Treatment: Items associated with veterinary offices are included in this category.

8. Funerary Services: Items associated with funeral homes and cemeteries are included here.

9. Entertainment: Items associated with theaters, movies, arcades, carnivals, and related miscellaneous items are included here.

10. Information Services $\checkmark$ : Newspapers, brochures and the like would be found here.

\section{Group Service}

A. Government Administration

1. Political Organization: This category is intended for campaign-associated materials and related miscellaneous items.

2. Bureaucratic Organizations: License plates and related miscellaneous items are examples of this category.

3. Trappings of a Public Office: Gavels, flags, books, and related miscellaneous items are examples of this category.

B. Public Safety

1. Fire: Fire extinguishers, fire engines, fire hydrants and plugs, and related miscellaneous items and equipment that a fireman would use are examples in this category.

2. Police: Tickets, firearms, badges, and related miscellaneous items are found here.

3. Civil Defense or Militia: The adornment, firearms, and related miscellaneous items associated with these orga- 
nizations are recognized by this category.

4. Military Defense: At sites like Fort McKavett, the diagnostic military artifacts are in this category. The body of the present report includes military arms and ammunition and items of clothing and equipment.

C. Education

1. School: Besides the building and its furnishings, supplies such as pens, pencils, slateboards, books, paper, and related miscellaneous items are categorized as school related. There is obvious ambiguity when such items are separated from a school building as when they are found in the home environment. In such cases, context is used to make distinctions.

2. Library: Books, rubber stamps, and the like are categorized as items associated with libraries. Context is important in making such determinations.

3. Museums and Galleries: This category has no subcategories.

4. Research Facilities: This category has no subcategories.

D. Public Forum and Entertainment

1. Meeting House Trappings: A gavel would be an example of an item associated with this category. See also, Group Services-Government Administration (above).

2. Parks and Playground Equipment: Swings, slides, and related miscellaneous items are anticipated in this category.

3. Public Art: This category has no subcategories.

E. Utilities

1. Communication System: Telephones, telegraphs, and related miscellaneous items might be found here.

2. Transportation System: Public transportation by bus, trolley, airplane, railroad, or taxi, and related miscellaneous items are intended here.

3. Mail: Post office, mailbox, and related miscellaneous items comprise this category.

4. Water Supply: Wells, water trucks, pipes for delivery of water, water meters, and related miscellaneous items are placed in this category. See also, Architecture-Plumbing.

5. Sewage: Pipes, ditches, treatment plants, and related miscellaneous items having to do with the disposal of wastewater and sewage are found in this category. See also, ArchitecturePlumbing.

6. Trash Disposal: Trash cans, vehicles associated with trash disposal, places where trash is burned, dumps, and related miscellaneous items are found here. See also Domestic Items-Housewares and Appliances-Portable Waste Disposal and Sanitation.

7. Power: Lines, pipes, and circuit boxes are items found in this category. See also Architecture-Fixed Illumination and Power-Electrical.

8. Penal: This category has no subcategories.

\section{Group Ritual}

A. Religious Paraphernalia: The Christian cross, houses of worship, communion cups, holy books, and related miscellaneous items comprise this category. See also, Personal and Domestic Transportation-Ritual. Context is determinative.

B. Fraternal Paraphernalia: Robes, maces, and related miscellaneous items are examples of this category.

C. Public Monuments: This category has no subcategories.

VIII. Unknowns

A. Metal $\checkmark$ : The lab recognized ferrous, cuprous (brass or copper), lead or white metal, tin, aluminum, gold, silver, and miscellaneous as divisions under this category.

B. Glass $\checkmark$ : Glass assigned to this category is limited to descriptive classification, e.g., color.

C. Ceramic $\checkmark$ : The classes earthenware, stoneware, porcelain, terra cotta, miscellaneous, and prehistoric are recognized under this category.

D. Bone $\checkmark$ : Bone, teeth, bone and teeth (jaw), artifact, and miscellaneous are recognized 
under this category.

E. Ethno-organic $\checkmark$ : This category refers to seeds, egg shell, fiber (string or rope), shell, leather, wood or charcoal, soil (sample or burned clay), miscellaneous, and paper (cardboard).

F. Lithic $\checkmark$

1. Cultural: Included are tools and cores of chipped stone (dart points, arrow points, scrapers, modified flakes, gravers, perforators/drills, bifaces, unifaces, cores, gouges, choppers, and miscellaneous), and ground/pecked stone (metates, manos, hammerstones, mortars, pestles, and miscellaneous), as well as debitage (flakes and shatter) and burned rocks.

2. Rock: This category includes pigment and has no subcategories.

3. Fossil: This category has no subcategories.

4. Coal: This category has no subcategories.

G. Plastic and Rubber $\checkmark$

1. Plastic: This category includes cellophane and has no subcategories.

2. Rubber: This category has no subcategories.

H. Unknown: This category has no subcategories. 


\title{
APPENDIX D: Analysis of the Archeovertebrate Remains from Officers' Quarters 4
}

\author{
Brian S. Shaffer
}

Zooarchaeology Laboratory University of North Texas Denton, Texas 76203-6078 


\section{INTRODUCTION}

The broad goals of the analysis of the vertebrate faunal remains from the Fort McKavett testing and data recovery are to provide taxonomic identifications and to identify cultural patterns as reflected by the materials. Due to the mixing of military and civilian materials, and hence food (faunal) refuse, these patterns reflect a part of the diet that would be expected in frontier Texas, in and around a fort of the period, and in rural Texas in the late nineteenth and early twentieth centuries. This information is presented by Officers' Quarters 4 room or exterior provenience and not in a stratigraphic manner. Additional factors of butchering, intrusive or commensal taxa (present and absent), and pathologies observed in the Officers' Quarters 4 materials also are discussed.

\section{METHODS}

The faunal remains from Officers' Quarters 4 were divided into seven general provenience areas including the kitchen, the latrine, Rooms $0-3$, and the south portion of the back yard. Since the sediments were generally shallow and apparently turbated and contained historical artifacts ranging from the nineteenth-century fort occupation to recent remains, provenience by level was not a valid distinction for analysis (Amy Earls, personal communication 1995). Faunal attributes recorded include taxon, element, portion of element, side, criteria on which ages were assigned, age of the animal, basic taphonomic information, and butchery. The taphonomic information includes weathering, breakage, burning, cut marks, and any additional information. Butchered elements were recorded based upon the type of instrument used, location of the cut, and, if assessable, the specific cut of meat represented. Unique observations, such as pathological disorders, were recorded in a comments field. Unique or culturally modified specimens were observed under magnification with either a $10 \mathrm{x}$ hand lens or a light microscope up to $30 \mathrm{x}$. Attribute recording was accomplished using a vertebrate coding system (Shaffer and Baker 1992).

Identifications were made using the University of North Texas, Institute of Applied Sciences' zooarcheology collection. Osteological guides used to aid in the identification include Calovich and Branson (1964) and Mundell (1975) for fish,
Auffenberg (1969) and Olsen (1968) for snake and other herpetofauna, Lawrence (1951) for deer and pronghorn, and Balkwill and Cumbaa (1992) and Olsen (1960) for cattle and bison. Additional mammalian remains were identified with the aid of Glass (1951), Hillson (1986), Schmid (1972), and Olsen (1964). No identifications were made solely upon criteria provided in the guides. If only guide information was available for identification, or if the identification was tentative, then the identification was listed as "cf." (compares favorably) (see Tables 12 and 13).

Several problems encountered during the analysis limited the amount of information that could be gleaned from the sample. First, limitations of the faunal collection reduced the number of identifications possible. For example, more than 247 freshwater species of fish occupy Texas (Hubbs et al 1991:1), of which 81 are currently found in the Fort McKavett region. Comparative skeletal elements in the varying sizes in which the taxa occur were not available. This problem was also apparent with birds where more than 540 species (a full threequarters of all avian taxa that occur in the continental United States) either live in or migrate through Texas (Peterson 1963:ix). Once again, comparative skeletal remains were not available for all of the taxa. Also, taphonomic factors of burning, breakage, and root etching all affect the condition of the specimens that reach the analyst, usually in an adverse manner. Thus, identifications were made to the most specific level possible, given the comparative material available, the site's geographic area, taphonomic factors, and the analyst's skill.

Quantification of the Fort McKavett faunal remains followed two methods: number of identified specimens (NISP) and minimum number of individuals (MNI) (Tables 12 and 13). NISP is simply the specimen counts for the assemblage and for the identified taxa. In cases of articulated specimens, such as mandibles and teeth, the teeth were recorded and counted separately from the mandibles so that MNIs could be computed on both loose and articulated specimens. MNIs were calculated based on the most frequent element for each identified age class for each taxon. Areas within Officers' Quarters 4 were not used as individual aggregation units since there is no way to determine whether the areas were mutually exclusive for the faunal remains. Note that comparable categories of taxa were combined for MNI purposes. For example, 
TABLE 12

NUMBER OF IDENTIFIED FAUNAL SPECIMENS

\begin{tabular}{|c|c|c|c|}
\hline Taxon & Common Name & NISP & \\
\hline Vertebrata & Vertebrates & 835 & \\
\hline Osteichthyes (small) & Small bony fish & 6 & \\
\hline cf. Osteichthyes (small) & Small bony fish & 2 & \\
\hline Osteichthyes (medium) & Medium bony fish & 18 & \\
\hline cf. Osteichthyes (medium) & Medium bony fish & 1,050 & \\
\hline Osteichthyes (large) & Large bony fish & 2 & \\
\hline cf. Osteichthyes (large) & Large bony fish & 2 & \\
\hline Ictalurus sp. & Catfish & 14 & \\
\hline Ictalurus punctatus & Channel catfish & 1 & \\
\hline Anura & Toads and frogs & 3 & \\
\hline Testudinata & Turtles & 2 & \\
\hline Trionyx sp. & Softshell turtle & 9 & \\
\hline Colubridae & Colubrid snakes & 15 & \\
\hline Aves (medium) & Medium birds & 7 & \\
\hline Aves (large) & Large birds & 214 & \\
\hline cf. Aves (large) & Large birds & 1 & \\
\hline Aves & Birds & 4 & \\
\hline Anatidae & Ducks & 6 & \\
\hline cf. Anatidae & Ducks & 2 & \\
\hline Phasianidae & Quail & 2 & \\
\hline Gallus gallus & Domestic chicken & 29 & \\
\hline cf. Gallus gallus & Domestic chicken & 28 & \\
\hline Meleagris gallopavo & Turkey & 7 & \\
\hline cf. Meleagris gallopavo & Turkey & 1 & \\
\hline cf. Numida sp. & Guineafowl & 1 & \\
\hline cf. Columba sp. & Pigeons and doves & 1 & \\
\hline cf. Zenaida sp. & Doves & 1 & \\
\hline Mammalia (small/medium) & Rabbit/canid-sized mammals & 33 & \\
\hline Mammalia (medium) & Canid-sized mammals & 6 & \\
\hline Mammalia (medium/large) & Canid/deer-sized mammals & 1,030 & \\
\hline Mammalia (large/very large) & Deer/bison-sized mammals & 104 & \\
\hline Mammalia (very large) & Bison-sized mammals & 38 & \\
\hline Mammalia & Mammals & 50 & \\
\hline Lepus sp. & Jackrabbits & 7 & \\
\hline Sylvilagus sp. & Cottontail rabbits & 64 & \\
\hline cf. Sylvilagus sp. & Cottontail rabbits & 8 & \\
\hline Rodentia (small) & Small rodent & 1 & \\
\hline Rodentia (medium) & Medium rodent & 2 & \\
\hline Sciuridae & Squirrels and chipmunks & 10 & \\
\hline Peromyscus sp. & Mice & 11 & \\
\hline cf. Peromyscus sp. & Mice & 1 & \\
\hline Felis domesticus & Domestic cat & 151 & \\
\hline cf. Felis domesticus & Domestic cat & 7 & \\
\hline Artiodactyla (medium) & Deer/pronghorn-sized ungulates & 25 & - \\
\hline Artiodactyla (large) & Bison/cow-sized ungulates & 3 & 1 \\
\hline Sus scrofa & Pig & 123 & 3 \\
\hline cf. Sus scrofa & Pig & 14 & \\
\hline Odocoileus sp. & Deer & 7 & \\
\hline Bos sp. & Cattle & 4 & \\
\hline cf. Bos sp. & Cattle & 2 & \\
\hline Bos/Bison & Cattle/bison & 16 & \\
\hline
\end{tabular}




\begin{tabular}{|l|l|r|}
\hline \multicolumn{2}{|l|}{ Table 12, continued } & NISP \\
\hline Taxon & Common Name & 1 \\
\hline cf. Bos/Bison & Cattle/bison & 27 \\
Capra hircus & Goat & 9 \\
Ovis/Capra & Sheep/goat & 1 \\
cf. Ovis/Capra & Sheep/goat & 1 \\
Equus sp. & Horses and relatives & 4,019 \\
Total: & & \\
\hline
\end{tabular}

\begin{tabular}{|c|c|c|}
\hline \multicolumn{3}{|c|}{$\begin{array}{c}\text { TABLE } 13 \\
\text { MINIMUM NUMBER OF INDIVIDUALS FOR IDENTIFIED TAXA }\end{array}$} \\
\hline Taxon & Common Name & MNI \\
\hline Ictalurus sp. & Catfish & 3 \\
\hline Anura & Toads and frogs & 1 \\
\hline Trionyx sp. & Softshell turtle & 1 \\
\hline Colubridae & Colubrid snakes & 1 \\
\hline Anatidae & Ducks & 2 \\
\hline Phasianidae & Quail & 1 \\
\hline Gallus gallus & Domestic chicken & 4 \\
\hline Meleagris gallopavo & Turkey & 2 \\
\hline cf. Numida sp. & Guineafowl & 1 \\
\hline cf. Columba sp. & Pigeons and doves & 1 \\
\hline cf. Zenaida sp. & Doves & 1 \\
\hline Lepus sp. & Jackrabbits & 1 \\
\hline Sylvilagus sp. & Cottontail rabbits & 3 \\
\hline Sciuridae & Squirrels and chipmunks & 1 \\
\hline Peromyscus sp. & Mice & 2 \\
\hline Felis domesticus & Domestic cat & 3 \\
\hline Sus scrofa & Pig & 4 \\
\hline Odocoileus sp. & Deer & 1 \\
\hline Bos sp. & Cattle & 2 \\
\hline Capra hircus & Goat & 3 \\
\hline Equus sp. & Horses and relatives & 1 \\
\hline
\end{tabular}

specimens identified as Gallus gallus and cf. Gallus gallus were combined to determine the MNI for chicken.

\section{GENERAL TAPHONOMY}

Taphonomy refers to those factors affecting the bone in its transition from the biosphere (life) to the lithosphere (fossilization) (Efremov 1940). Those factors at Fort McKavett affecting bones include weathering, breakage, burning, butchering, and gnawing. Weathering apparently did not significantly affect the faunal assemblage. Only 39 of the 3,934 nontooth specimens were recorded with marked weathering. Marked weathering was identified based on the presence of bleaching, fine-line cracks, exfoliation of bone layers, or pronounced cracking and exfoliation. The preservation of 1,029 scales indicates light weathering as well. With such a high level of lightly weathered faunal material, it appears that the sample was buried relatively quickly or was protected in some way (under buildings?) from exposure to the weathering conditions.

Breakage also affected much of the assemblage, although it was not recorded for the 1,029 scale remains, thus leaving a total of 2,990 specimens where breakage was assessed. Of these specimens, 2,595 (87 percent) were recorded as broken and 395 
(13 percent) as complete. Two patterns of breakage were recorded-angular (or dry bones) and spiral (green bones) - which usually occur in bones with thick cortical walls, such as long shafts. Angular fractures occur in bones that have lost collagen and are no longer fresh, and in some elements or taxa where the bones and teeth simply cannot break in a spiral fracture (e.g., turtle shells, skull fragments, fish bones, scales, podials). Spiral fractures indicative of fresh bone breakage (Johnson 1985:172) are frequent $(n=348,19$ percent of sample capable of spiral fractures). While relatively high percentages of spirally fractured bones may be used as an indicator of marrow processing at Native American sites, there is no indication of marrow processing at Fort McKavett. Instead, the high percentage of spirally fractured bones may simply be associated with meat processing.

Burning played a minor role in the taphonomic history of the vertebrate materials recovered from Officers' Quarters 4. Only 77 specimens are burned. Of these, 32 are charred (burned black) and 45 are calcined (burned white). A more numerous taphonomic factor is that of butchering. Cut marks made by smooth-bladed implements (knives?), chopping tools (cleavers?), hand saws, and band saws were observed on 99 specimens.

Evidence of gnawing was infrequent. While most of the bones identified with gnawing from Texas archeological sites are usually rodent gnawed, only one of the six gnawed specimens from Officers' Quarters 4 was gnawed by a rodent. This specimen is a medium-sized artiodactyl accessory carpal bone recovered from Room 3. The other specimens were gnawed by carnivores as indicated by sharp tooth drag marks or by canine tooth puncture marks.

Carnivore-gnawed/chewed specimens include a medium-sized artiodactyl distal femur from Room 1 with the distal end gnawed off and tooth drag marks present on the shaft. A medium/large mammal humerus fragment from Room 1 also is damaged. These two specimens probably were gnawed by a larger carnivore such as a canine. The last three specimens were gnawed by a smaller, probably domestic, cat-sized carnivore. A cottontail complete left femur from Room 1 exhibits two sets of opposing puncture marks, consistent with carnivore canine tooth punctures. One set of two opposing holes is at the proximal end of the bone, and the holes are located on the anterior and posterior surfaces be- tween the head and greater trochanter. The second set of punctures consists of one hole on the distal anterior lateral surface, just lateral to the patellar groove and two side-by-side holes (from subsequent bites?) on the distal medial surface, just medial to the patellar groove and more distal than the first mark. Similar opposing punctures were observed on a jackrabbit scapula neck portion from the kitchen area that exhibits multiple opposing punctures. Lastly, a large bird distal humerus from the kitchen area exhibits a single puncture as well. None of the gnawed specimens is burned.

\section{DISCUSSION BY AREA}

The taxa and their NISP frequencies by area are presented in Tables 14 and 15, with Table 15 presenting a summary of identified taxa. In looking at specific areas, the Kitchen area has all of these taxa except snake and horse. This is not unexpected given that it also has the largest sample size (see Table 14). The kitchen is followed in variety by Room 3, Room 0, the back yard, Rooms 1 and 2, and then the Latrine (in respective order). While the widest variety of taxa are located in the kitchen area, frequencies are not always highest there, but they are for fish (mostly scales), all birds but chicken, jackrabbit, pig, and cow/bison. In looking at cultural taphonomic factors (Table 16), the kitchen has the most spiral breaks, charred remains, and butchered bones (keep in mind it has the largest sample size). The large number of fish scales from this area, and the fact that none are burned, would indicate that fish were scaled before being consumed.

The latrine has the smallest sample and the least variety (see Tables 14 and 15), although it possesses the largest concentration of chicken bones. Surprisingly, more than half of the calcined bones from Officers' Quarters 4 (24 of 45) are from the latrine, and this area also has the highest concentration of burned bones, with 25 of the 98 burned specimens ( 26 percent) recovered.

In the main structure, Room 0 had the third smallest faunal sample with 155 specimens recovered (see Table 14), but it had the second most diverse assemblage behind the Kitchen. Not surprisingly, pig dominates the identified assemblage and fish are the second most frequent, but cow/bison and goat/ sheep probably actually represent a higher proportion of economic food remains than the first two taxa. 
Appendix D: The Archeovertebrate Remains from Officers' Quarters 4

TABLE 14

TAXA BY PROVENIENCE

\begin{tabular}{|c|c|c|}
\hline Taxon & Common Name & Totals \\
\hline \multicolumn{3}{|c|}{ KITCHEN AREA } \\
\hline Vertebrata & Vertebrates & 526 \\
\hline Osteichthyes (small) & Small bony fish & 3 \\
\hline cf. Osteichthyes (small) & Small bony fish & 2 \\
\hline Osteichthyes (medium) & Medium bony fish & 11 \\
\hline cf. Osteichthyes (medium) & Medium bony fish & 1,038 \\
\hline Osteichthyes (large) & Large bony fish & 1 \\
\hline cf. Osteichthyes (large) & Large bony fish & 2 \\
\hline Ictalurus sp. & Catfish & 6 \\
\hline Anura & Toads and frogs & 2 \\
\hline Testudinata & Turtles & 2 \\
\hline Trionyx sp. & Softshell turtle & 3 \\
\hline Aves (medium) & Medium birds & 4 \\
\hline Aves (large) & Large birds & 94 \\
\hline Aves & Birds & 2 \\
\hline Anatidae & Ducks, swans, and geese & 2 \\
\hline cf. Anatidae & Ducks, swans, and geese & 1 \\
\hline Phasianidae & Quail & 1 \\
\hline Gallus gallus & Domestic chicken & 5 \\
\hline cf. Gallus gallus & Domestic chicken & 3 \\
\hline Meleagris gallopavo & Turkey & 3 \\
\hline cf. Meleagris gallopavo & Turkey & 1 \\
\hline cf. Numida sp. & Guineafowl & 1 \\
\hline cf. Columba sp. & Pigeons and doves & 1 \\
\hline cf. Zenaida sp. & Doves & 1 \\
\hline Mammalia (small/medium) & Rabbit/canid-sized mammals & 11 \\
\hline Mammalia (medium/large) & Canid/deer-sized mammals & 554 \\
\hline Mammalia (large/very large) & Deer/bison-sized mammals & 71 \\
\hline Mammalia (very large) & Bison-sized mammals & 20 \\
\hline Mammalia & Mammals & 41 \\
\hline Lepus sp. & Jackrabbits & 4 \\
\hline Sylvilagus sp. & Cottontail rabbits & 10 \\
\hline Sciuridae & Squirrels and chipmunks & 1 \\
\hline Felis domesticus & Domestic cat & 5 \\
\hline cf. Felis domesticus & Domestic cat & 6 \\
\hline Artiodactyla (medium) & Deer/pronghorn-sized ungulates & 10 \\
\hline Artiodactyla (large) & Bison/cow-sized ungulates & 1 \\
\hline Sus scrofa & Pig & 44 \\
\hline cf. Sus scrofa & Pig & 3 \\
\hline Odocoileus sp. & Deer & 2 \\
\hline cf. Bos sp. & Cattle & 2 \\
\hline Bos/Bison & Cattle/bison & 6 \\
\hline cf. Bos/Bison & Cattle/bison & 1 \\
\hline Capra hircus & Goat & 1 \\
\hline Ovis/Capra & Sheep/goat & 3. \\
\hline Subtotal: & & 2,511 \\
\hline
\end{tabular}




\begin{tabular}{|c|c|c|}
\hline Taxon & Common Name & Totals \\
\hline \multicolumn{3}{|c|}{ LATRINE } \\
\hline $\begin{array}{l}\text { Vertebrata } \\
\text { Trionyx sp. } \\
\text { Aves (large) } \\
\text { Gallus gallus } \\
\text { cf. Gallus gallus } \\
\text { Mammalia (small/medium) } \\
\text { Mammalia (medium/large) } \\
\text { Mammalia (large/very large) } \\
\text { Sus scrofa } \\
\text { Bos/Bison } \\
\quad \text { Subtotal: }\end{array}$ & $\begin{array}{l}\text { Vertebrates } \\
\text { Softshell turtle } \\
\text { Large birds } \\
\text { Domestic chicken } \\
\text { Domestic chicken } \\
\text { Rabbit/canid-sized mammals } \\
\text { Canid/deer-sized mammals } \\
\text { Deer/bison-sized mammals } \\
\text { Pig } \\
\text { Cattle/bison }\end{array}$ & $\begin{array}{r}25 \\
1 \\
4 \\
19 \\
17 \\
1 \\
23 \\
3 \\
4 \\
1 \\
98\end{array}$ \\
\hline \multicolumn{3}{|c|}{ ROOM 0} \\
\hline $\begin{array}{l}\text { Vertebrata } \\
\text { cf. Osteichthyes (medium) } \\
\text { Ictalurus sp. } \\
\text { Ictalurus punctatus } \\
\text { Aves (medium) } \\
\text { Aves (large) } \\
\text { Anatidae } \\
\text { cf. Anatidae } \\
\text { Gallus gallus } \\
\text { cf. Gallus gallus } \\
\text { Mammalia (small/medium) } \\
\text { Meleagris gallopavo } \\
\text { Mammalia (medium/large) } \\
\text { Mammalia (large/very large) } \\
\text { Mammalia (very large) } \\
\text { Mammalia } \\
\text { Lepus sp. } \\
\text { Sylvilagus sp. } \\
\text { Rodentia (small) } \\
\text { Sciuridae } \\
\text { Felis domesticus } \\
\text { Artiodactyla (medium) } \\
\text { Sus scrofa } \\
\text { Odocoileus sp. } \\
\text { Bos/Bison } \\
\text { Capra hircus } \\
\text { Ovis/Capra } \\
\text { cf. Ovis/Capra } \\
\text { Subtotal: }\end{array}$ & $\begin{array}{l}\text { Vertebrates } \\
\text { Medium bony fish } \\
\text { Catfish } \\
\text { Channel catfish } \\
\text { Medium birds } \\
\text { Large birds } \\
\text { Ducks, swans, and geese } \\
\text { Ducks, swans, and geese } \\
\text { Domestic chicken } \\
\text { Domestic chicken } \\
\text { Rabbit/canid-sized mammals } \\
\text { Turkey } \\
\text { Canid/deer-sized mammals } \\
\text { Deer/bison-sized mammals } \\
\text { Bison-sized mammals } \\
\text { Mammals } \\
\text { Jackrabbits } \\
\text { Cottontail rabbits } \\
\text { Small rodent } \\
\text { Squirrels and chipmunks } \\
\text { Domestic cat } \\
\text { Deer/pronghorn-sized ungulates } \\
\text { Pig } \\
\text { Deer } \\
\text { Cattle/bison } \\
\text { Goat } \\
\text { Sheep/goat } \\
\text { Sheep/goat }\end{array}$ & $\begin{array}{r}46 \\
6 \\
7 \\
1 \\
2 \\
2 \\
1 \\
1 \\
1 \\
1 \\
3 \\
1 \\
37 \\
4 \\
1 \\
1 \\
1 \\
2 \\
1 \\
1 \\
3 \\
2 \\
19 \\
1 \\
4 \\
4 \\
1 \\
1 \\
155\end{array}$ \\
\hline \multicolumn{3}{|c|}{ ROOM 1} \\
\hline $\begin{array}{l}\text { Vertebrata } \\
\text { Osteichthyes (small) } \\
\text { Osteichthyes (medium) } \\
\text { cf. Osteichthyes (medium) } \\
\text { Osteichthyes (large) } \\
\text { Ictalurus sp. }\end{array}$ & $\begin{array}{l}\text { Vertebrates } \\
\text { Small bony fish } \\
\text { Medium bony fish } \\
\text { Medium bony fish } \\
\text { Large bony fish } \\
\text { Catfish }\end{array}$ & $\begin{array}{r}53 \\
2 \\
6 \\
1 \\
1 \\
1\end{array}$ \\
\hline
\end{tabular}




\begin{tabular}{|c|c|c|}
\hline \multicolumn{3}{|l|}{ Table 14, continued } \\
\hline Taxon & Common Names & Totals \\
\hline \multicolumn{3}{|c|}{ ROOM 1, continued } \\
\hline $\begin{array}{l}\text { Aves (large) } \\
\text { Anatidae } \\
\text { Gallus gallus } \\
\text { cf. Gallus gallus } \\
\text { Meleagris gallopavo } \\
\text { Mammalia (small/medium) } \\
\text { Mammalia (medium) } \\
\text { Mammalia (medium/large) } \\
\text { Mammalia (large/very large) } \\
\text { Mammalia (very large) } \\
\text { Sylvilagus sp. } \\
\text { cf. Sylvilagus sp. } \\
\text { Sciuridae } \\
\text { Felis domesticus } \\
\text { Artiodactyla (medium) } \\
\text { Artiodactyla (large) } \\
\text { Sus scrofa } \\
\text { Capra hircus } \\
\text { Ovis/Capra } \\
\text { Subtotal: }\end{array}$ & $\begin{array}{l}\text { Large birds } \\
\text { Ducks, swans, and geese } \\
\text { Domestic chicken } \\
\text { Domestic chicken } \\
\text { Turkey } \\
\text { Rabbit/canid-sized mammals } \\
\text { Canid-sized mammals } \\
\text { Canid/deer-sized mammals } \\
\text { Deer/bison-sized mammals } \\
\text { Bison-sized mammals } \\
\text { Cottontail rabbits } \\
\text { Cottontail rabbits } \\
\text { Squirrels and chipmunks } \\
\text { Domestic cat } \\
\text { Deer/pronghorn-sized ungulates } \\
\text { Bison/cow-sized ungulates } \\
\text { Pig } \\
\text { Goat } \\
\text { Sheep/goat }\end{array}$ & $\begin{array}{r}8 \\
2 \\
1 \\
1 \\
2 \\
3 \\
1 \\
141 \\
10 \\
8 \\
42 \\
8 \\
3 \\
4 \\
5 \\
1 \\
5 \\
10 \\
1 \\
320\end{array}$ \\
\hline \multicolumn{3}{|c|}{ ROOM 2} \\
\hline $\begin{array}{l}\text { Vertebrata } \\
\text { cf. Osteichthyes (medium) } \\
\text { Anura } \\
\text { Aves (medium) } \\
\text { Aves (large) } \\
\text { cf. Aves (large) } \\
\text { Gallus gallus } \\
\text { cf. Gallus gallus } \\
\text { Mammalia (small/medium) } \\
\text { Mammalia (medium) } \\
\text { Mammalia (medium/large) } \\
\text { Mammalia (large/very large) } \\
\text { Mammalia (very large) } \\
\text { Mammalia } \\
\text { Sylvilagus sp. } \\
\text { Sciuridae } \\
\text { Felis domesticus } \\
\text { cf. Felis domesticus } \\
\text { Artiodactyla (medium) } \\
\text { Sus scrofa } \\
\text { cf. Sus scrofa } \\
\text { Odocoileus sp. } \\
\text { Bos sp. } \\
\text { Bos/Bison } \\
\text { Capra hircus } \\
\text { Ovis/Capra } \\
\text { Subtotal: }\end{array}$ & $\begin{array}{l}\text { Vertebrates } \\
\text { Medium bony fish } \\
\text { Toads and frogs } \\
\text { Medium birds } \\
\text { Large birds } \\
\text { Large birds } \\
\text { Domestic chicken } \\
\text { Domestic chicken } \\
\text { Rabbit/canid-sized mammals } \\
\text { Canid-sized mammals } \\
\text { Canid/deer-sized mammals } \\
\text { Deer/bison-sized mammals } \\
\text { Bison-sized mammals } \\
\text { Mammals } \\
\text { Cottontail rabbits } \\
\text { Squirrels and chipmunks } \\
\text { Domestic cat } \\
\text { Domestic cat } \\
\text { Deer/pronghorn-sized ungulates } \\
\text { Pig } \\
\text { Pig } \\
\text { Deer } \\
\text { Cattle } \\
\text { Cattle/bison } \\
\text { Goat } \\
\text { Sheep/goat }\end{array}$ & $\begin{array}{r}108 \\
2 \\
1 \\
1 \\
99 \\
1 \\
3 \\
3 \\
10 \\
1 \\
106 \\
3 \\
2 \\
1 \\
4 \\
4 \\
12 \\
1 \\
1 \\
21 \\
7 \\
1 \\
4 \\
2 \\
4 \\
1 \\
403\end{array}$ \\
\hline
\end{tabular}




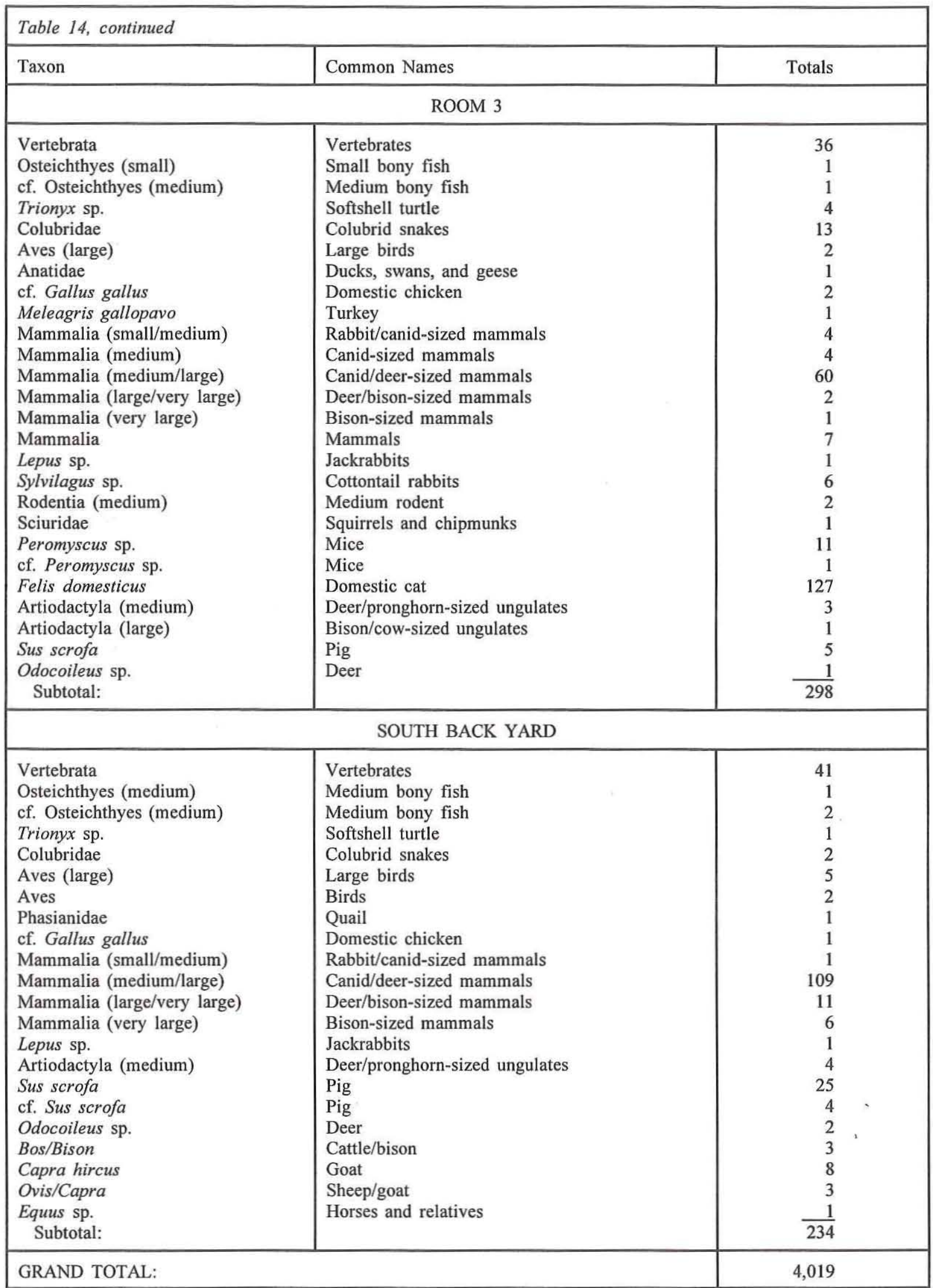




\begin{tabular}{|c|c|c|c|c|c|c|c|c|}
\hline \multicolumn{9}{|c|}{$\begin{array}{l}\text { TABLE } 15 \\
\text { SELECTED AND IDENTIFIED TAXA BY FEATURE* }\end{array}$} \\
\hline Taxon & Kitchen & Latrine & Room 0 & Room 1 & Room 2 & Room 3 & Yard & Totals \\
\hline Fish (all) & 1,589 & - & 14 & 11 & 2 & 2 & 3 & 1,691 \\
\hline Turtle & 5 & 1 & - & - & - & 4 & 1 & 11 \\
\hline Snake & - & - & - & - & - & 13 & 2 & 15 \\
\hline Duck & 3 & - & 2 & 2 & - & 1 & - & 8 \\
\hline Quail & 1 & - & - & - & - & - & 1 & 2 \\
\hline Chicken & 8 & 36 & 2 & 2 & 6 & 2 & 1 & 57 \\
\hline Turkey & 4 & - & 1 & 2 & - & 1 & - & 8 \\
\hline Guineafowl & 1 & - & - & - & - & - & - & 1 \\
\hline Pigeon & 1 & - & - & - & - & - & - & 1 \\
\hline Dove & 1 & - & - & - & - & - & - & 1 \\
\hline Jackrabbit & 4 & - & 1 & - & - & 1 & 1 & 7 \\
\hline Cottontail & 10 & - & 2 & 50 & 4 & 6 & - & 72 \\
\hline Rodents (all) & 1 & - & 2 & 3 & 4 & 15 & - & 25 \\
\hline Cat & 11 & - & 3 & 4 & 13 & 127 & - & 158 \\
\hline Deer & 2 & - & 1 & - & 1 & 1 & 2 & 7 \\
\hline Pig & 47 & 4 & 19 & 5 & 28 & 5 & 29 & 137 \\
\hline Cow/Bison & 9 & 1 & 4 & - & 6 & - & 3 & 23 \\
\hline Goat/Sheep & 4 & - & 6 & 11 & 5 & - & 11 & 37 \\
\hline Horse & - & - & - & - & - & - & 1 & 1 \\
\hline
\end{tabular}

\begin{tabular}{|l|c|c|c|r|r|}
\hline \multicolumn{5}{|c|}{ TABLE 16 } \\
\hline \multirow{4}{*}{ Feature } & Breakage & \multicolumn{2}{|c|}{ Burning Stages } & \\
\\
\cline { 2 - 4 } & Spiral & Charred & Calcined & Butchering & Sample Size \\
\hline Kitchen & 143 & 24 & 9 & 53 & 2,511 \\
Latrine & 4 & 1 & 24 & 3 & 98 \\
Room 0 & 10 & - & - & 2 & 155 \\
Room 1 & 106 & 2 & - & 5 & 320 \\
Room 2 & 37 & - & - & 13 & 403 \\
Room 3 & 18 & 3 & 8 & 7 & 298 \\
South part of back yard & 30 & 2 & 4 & 16 & 234 \\
\hline Total Specimens: & 348 & 32 & 45 & 99 & 4,019 \\
\hline
\end{tabular}

None of the specimens from Room 0 are burned, but 10 are spirally fractured and 2 show evidence of butchering (see Table 16).

While Room 1 has a variety of taxa that are recognized as being of economic importance (fish, chicken, turkey, rabbit, pig, sheep/goat), given the sample size of Room $1(n=320)$, it is surprising that nearly one-third of the sample of spirally fractured bones are from this area $(n=106$, see Table 16). At this time, no reason is apparent to explain this observation.

Rooms 2 and 3 have a variety of taxa, none of which are unexpected, except for the recovery of a large number of cat and rodent remains from Room 3 and most of the snake remains from the site (see Tables 14 and 15). Like Room 0, Room 2 also did 
not have any bones identified as being burned, but it did have the third highest frequency of butchered bones. Of particular interest in Room 3 are the high frequencies of cat, rodent, and rabbit remains (see Tables 14 and 15). The high frequency of cat remains stems from the recovery of what appears to be the majority of a domestic cat skeleton (minus the head and various small bones). This area may represent a location where these animals could shelter either commensally with human occupation or after abandonment of the structure by humans. However, the association of cat and mouse bones from the same lot within Room 3 may indicate that they were interred together (see discussion of "Walling Up Cats?" in the Unique Observations section below). The snake specimens from Room 3 probably represent an animal not associated with the human occupants at the site as indicated by the lack of cultural modification to the snake remains.

The south part of the back yard (or yard) provenience includes other exterior proveniences as well as miscellaneous yard proveniences and is not really cohesive (Amy Earls, personal communication 1995). The faunal sample is diverse, and most of the taxa are recognized economic taxa (see Tables 14 and 15). The only unique find is that of a horse upper tooth. While Fort McKavett was a cavalry fort, this is the only faunal evidence of horse from Officers' Quarters 4. This area had the second highest frequency of butchered bones.

\section{DOMESTIC EXPLOITED TAXA}

Apparently Fort McKavett never suffered any shortages of meat for consumption. According to Sullivan (1993:15), there was plenty of fresh beef, salt beef, and bacon. Both salt beef and bacon were shipped to the fort from other areas (Sullivan 1993:12-13). After abandonment of the fort in 1883 , the area became known for its commercial sheep, goat, and cattle ranches. An attempt was made to raise sheep and goats for mohair, hides, and canned goat meat (Sullivan 1993:57-58). The canned goat meat industry failed, but the mohair industry thrived. Combined, pig, cow, and goat/ sheep account for much of the domestic taxa present at Officers' Quarters 4. What is not reported by Sullivan is the presence of chicken and guineafowl which probably were kept locally. In support of birds being kept locally, aside from their osseous remains, are the remains of eggshells from the kitchen area, the south portion of the back yard, and Room 2. Based on the recovery of a variety of pig elements, including skulls, teeth, podials, and phalanges which normally are considered noneconomic elements, it appears that pigs were raised at the fort as well.

The recovery of juvenile (deciduous) pig teeth also indicates pigs were raised at the fort. Additional supporting evidence for pig raising at the fort comes from the Latrine area. Here, an articulated hind foot of a subadult pig (including metatarsal; proximal, middle, and distal phalanges; and three tarsals) was recovered. An articulated section of a goat hind foot, including the central/fourth tarsal, astragalus, calcaneus, and the spirally fractured distal end of a tibia, was recovered from the back yard.

It should be noted that not all domestic taxa were for culinary purposes only. As noted above, cats were present at the fort as were horses. Cats probably served as both pets and mousers. The use of horses is obvious at the fort, not only for military duties but also for sport. Pigs also had one unique use other than consumption. They also were used for sport. At the July 4, 1876, centennial celebration, aside from the rifle matches, foot races, and baseball game (Colonel Abner Doubleday, Fort Commander), horses were used in races, and there was a greased pig (catching) contest (Sullivan 1993:54).

Surprisingly absent from the Officers' Quarters 4 assemblage and mention by Sullivan are dogs. Dogs are common pets, serve as natural alarm systems, and are useful in hunting. If the officers of Officers' Quarters 4 had dogs, none of the dog remains were deposited in the immediate area.

\section{WILD EXPLOITED TAXA}

Chickens, pigs, and cows do not represent the only meats consumed by the people living in the Fort McKavett area. Hunting and fishing served to supplement the food supply and to provide a means of preventing boredom or to provide excitement for both soldiers and visitors (Sullivan 1993:53-54). Elliot Roosevelt, brother of Theodore, visited the fort in February and March 1876 and in April and May 1877 to hunt deer and turkey and to fish (Sullivan 1993:54).

Wild taxa identified from Officers' Quarters 4 that probably were exploited include unidentified fish, catfish, unidentified turtle, softshell turtle, duck, 
quail, dove, jackrabbit, cottontail, and deer. Pigeon and rodents (squirrels) may have been consumed as well. Other than presence in the assemblage, evidence for exploitation of most of these wild taxa is scant, with just 10 specimens exhibiting possible or definitive evidence of exploitation. Six of these are from the kitchen area. One deer radius and one metacarpal exhibit spiral fractures. One small fish spine is charred, and a catfish pectoral spine is calcined. Cut marks were observed on one large fish vertebra centrum that was chopped in two and on one dove (Zenaida sp.) carpometacarpus where the proximal condyle had been cut off (probably during disarticulation of the wing). The last four specimens come from Room 3. One softshell turtle shell fragment is charred, one duck coracoid is cut, and two cottontail tibia fragments are spirally fractured.

\section{BUTCHERING}

Butchering was identified on 99 specimens from Officers' Quarters 4 (Table 17). Identified butchering marks made by smooth-bladed implements (such as knives, chopping tools, and cleavers), hand saws, and band saws were observed on 84 specimens. Due to root etching or other deterioration on the bones, the type of implement used could not be identified for some of the butcher marks. Based on generic descriptions of the cuts made, saw marks are the most commonly identified cut marks, with 58 identified as being made by a hand saw, one by an undetermined type of saw, and one by a band saw. Chop cuts are the second most common, with complete chops (those completely bisecting the bone) totaling 13 , incomplete chops totaling 4 , and with 5 specimens recorded simply as chopped. It should be pointed out that one specimen (included in the totals already given) possesses both a hand saw cut and an incomplete chop. Lastly, three specimens have smooth blade cuts.

It should be pointed out that incomplete chops and smooth blade cuts may be overlapping categories in some cases. One pig humerus from the latrine has $6+$ smooth blade cuts that circumscribe the bone and apparently were made with a knife. However, whether other incomplete chop marks are actually incomplete chops or are just deep knife cuts could not be substantiated.

Based on the dominance of hand-sawed cuts of meat, no powered saws were used. The presence of one band-sawed specimen is probably a later intrusive specimen not associated with the fort or immediate post-fort occupation. Butchering may have taken place either locally (matching Sullivan's description of fresh beef availability [1993:15]) or off-site as indicated by Sullivan's description of salted beef and pork.

Not surprisingly, the kitchen area contained the highest number of cut specimens $(n=53)$ (see Table 17). This is followed by the back yard with 16 and Room 2 with 13, and each of the other areas had 7 or less. Due to the low number of identified cuts of meat and the relatively high number of fragmented remains with cut marks, it could not be determined if the cut material from the Kitchen area represents discarded or unserved portions. Another way of addressing this issue is by looking at the number of identifiable taxa from the three areas with the highest number of cut remains. The Kitchen area has the lowest number of identifiable taxa (4 of 53), followed by the back yard ( 2 of 16). This was expected since the kitchen and yard would potentially contain discarded scraps that were never eaten. However, 8 of the 13 cut specimens from Room 2 were identifiable. Two of these, a cow radius and ulna, appear to be a shank knuckle cut and fit together. Thus, the highest number of cut and identifiable specimens were found in an area where consumption of meat would have occurred (for those areas with more than seven specimens).

Based on a lack of discarded portions of carcasses, especially in the Kitchen area, it would appear that the butchering that occurred in the Kitchen area was tertiary and was not primary butchering, at least for cattle. Whether pigs were completely butchered in the Officers' Quarters 4 compound, or in its Kitchen area specifically, is not clear. Discarded and unused portions, such as heads, mandibles, pig's feet, etc., were recovered. Thus, primary butchery and discard of pig may have occurred in this area, although this cannot be substantiated or refuted with the actual cut mark evidence.

\section{Fish Butchering}

Only one large fish vertebra fragment from the kitchen area exhibits an actual cut mark. This is a complete chop that bisected the centrum. Other evidence for butchery comes from fish scales. The majority of fish scales ( $n=836$ of 1,029$)$ were 


\begin{tabular}{|c|c|c|c|c|c|c|}
\hline \multicolumn{7}{|c|}{ TABLE 17} \\
\hline No. & Taxon (Size)* & Element & Portion & Cut Type** & Cut of Meat & Comments \\
\hline \multicolumn{7}{|c|}{ KITCHEN AREA } \\
\hline $\begin{array}{l}1 \\
1 \\
6 \\
3 \\
4 \\
1 \\
2 \\
1 \\
1 \\
1 \\
1 \\
1 \\
1 \\
1 \\
2 \\
4 \\
1 \\
1 \\
1 \\
1 \\
1 \\
1 \\
1 \\
1 \\
1 \\
1\end{array}$ & $\begin{array}{l}\text { Osteichthyes (L) } \\
\text { Aves (L) } \\
\text { cf. Zenaida sp. } \\
\text { Mammalia (S/M) } \\
\text { Mammalia (M/L) } \\
\text { Mammalia (M/L) } \\
\text { Mammalia (M/L) } \\
\text { Mammalia (M/L) } \\
\text { Mammalia (M/L) } \\
\text { Mammalia (M/L) } \\
\text { Mammalia (M/L) } \\
\text { Mammalia (M/L) } \\
\text { Mammalia (M/L) } \\
\text { Mammalia (M/L) } \\
\text { Mammalia (M/L) } \\
\text { Mammalia (M/L) } \\
\text { Mammalia (M/L) } \\
\text { Mammalia (L/VL) } \\
\text { Mammalia (L/VL) } \\
\text { Mammalia (L/VL) } \\
\text { Mammalia (L/VL) } \\
\text { Mammalia (L/VL) } \\
\text { Mammalia (L/VL) } \\
\text { Mammalia (L/VL) } \\
\text { Mammalia (L/VL) } \\
\text { Mammalia (L/VL) } \\
\text { Mammalia (VL) } \\
\text { Mammalia (VL) }\end{array}$ & $\begin{array}{l}\text { Vertebra } \\
\text { Tibiotarsus } \\
\text { Carpometacarpus } \\
\text { Lumbar vertebra } \\
\text { Indeterminate } \\
\text { Indeterminate } \\
\text { Indeterminate } \\
\text { Indeterminate } \\
\text { Indeterminate } \\
\text { Indeterminate } \\
\text { Indeterminate } \\
\text { Vertebra } \\
\text { Rib } \\
\text { Scapula } \\
\text { Tibia } \\
\text { Long bone } \\
\text { Long bone } \\
\text { Indeterminate } \\
\text { Indeterminate } \\
\text { Indeterminate } \\
\text { Vertebra } \\
\text { Rib } \\
\text { Rib } \\
\text { Rib } \\
\text { Scapula } \\
\text { Long bone } \\
\text { Indeterminate } \\
\text { Indeterminate }\end{array}$ & $\begin{array}{l}\text { Fragment } \\
\text { Distal end } \\
\text { Complete } \\
\text { Saggital split, left portion } \\
\text { Fragment } \\
\text { Fragment } \\
\text { Fragment } \\
\text { Fragment } \\
\text { Fragment } \\
\text { Fragment } \\
\text { Fragment } \\
\text { Centrum epiphysis } \\
\text { Fragment } \\
\text { Blade portion } \\
\text { Fragment } \\
\text { Fragment } \\
\text { Fragment } \\
\text { Fragment } \\
\text { Fragment } \\
\text { Fragment } \\
\text { Centrum epiphysis } \\
\text { Vertebral end } \\
\text { Shaft fragment } \\
\text { Shaft fragment } \\
\text { Neck } \\
\text { Fragment } \\
\text { Fragment } \\
\text { Fragment }\end{array}$ & $\begin{array}{l}\text { Complete chop } \\
\text { Smooth blade cut } \\
\text { Cut } \\
\text { Complete chop } \\
\text { Double hand saw } \\
\text { Cut } \\
\text { Hand saw } \\
\text { Saw } \\
\text { Chop } \\
\text { Complete chop } \\
\text { Incomplete chop } \\
\text { Complete chop } \\
\text { Cut } \\
\text { Double hand saw } \\
\text { Double complete chop } \\
\text { Hand saw } \\
\text { Double hand saw } \\
\text { Double hand saw } \\
\text { Hand saw } \\
\text { Cut } \\
\text { Cut } \\
\text { Double hand saw } \\
\text { Double hand saw } \\
\text { Incomplete chop } \\
\text { Double hand saw } \\
\text { Hand saw } \\
\text { Double hand saw } \\
\text { Cut }\end{array}$ & $\begin{array}{l}\text { Blade steak } \\
\text { Round cut/discard } \\
\text { Blade steak }\end{array}$ & $\begin{array}{l}2 \text { transverse cuts across } \\
\text { distal condyle } \\
\text { distal condyle cut off }\end{array}$ \\
\hline
\end{tabular}




\begin{tabular}{|c|c|c|c|c|c|c|}
\hline \multicolumn{7}{|c|}{ Table 17, continued } \\
\hline No. & Taxon (Size) & Element & Portion & Cut Type & Cut of Meat & Comments \\
\hline \multicolumn{7}{|c|}{ KITCHEN AREA, continued } \\
\hline $\begin{array}{r}1 \\
2 \\
1 \\
1 \\
1 \\
1 \\
1 \\
1 \\
\frac{1}{53}\end{array}$ & $\begin{array}{l}\text { Mammalia (VL) } \\
\text { Mammalia (VL) } \\
\text { Mammalia (VL) } \\
\text { Mammalia (VL) } \\
\text { Mammalia (VL) } \\
\text { Mammalia (VL) } \\
\text { Sus scrofa } \\
\text { Bos/Bison } \\
\text { cf. Bos/Bison }\end{array}$ & $\begin{array}{l}\text { Vertebra } \\
\text { Vertebra } \\
\text { Rib } \\
\text { Tibia } \\
\text { Long bone } \\
\text { Long bone } \\
\text { Femur } \\
\text { Femur } \\
\text { Femur }\end{array}$ & $\begin{array}{l}\text { Centrum } \\
\text { Centrum epiphysis } \\
\text { Shaft fragment } \\
\text { Fragment } \\
\text { Fragment } \\
\text { Fragment } \\
\text { Fragment } \\
\text { Fragment } \\
\text { Fragment }\end{array}$ & $\begin{array}{l}\text { Chop } \\
\text { Hand saw } \\
\text { Double hand saw } \\
\text { Double hand saw } \\
\text { Double hand saw } \\
\text { Cut } \\
\text { Double hand saw } \\
\text { Double hand saw } \\
\text { Double complete chop }\end{array}$ & $\begin{array}{l}\text { Short rib } \\
\text { Hind shank } \\
\text { Round cut/discard } \\
\text { Round steak, pot roast } \\
\text { Round steak, pot roast } \\
\text { Round steak, pot roast }\end{array}$ & $\begin{array}{l}\text { "L" chop saggital and } \\
\text { transverse }\end{array}$ \\
\hline \multicolumn{7}{|c|}{ LATRINE } \\
\hline $\begin{array}{l}1 \\
1 \\
\frac{1}{3}\end{array}$ & $\begin{array}{l}\text { Sus scrofa } \\
\text { Sus scrofa } \\
\text { Sus scrofa }\end{array}$ & $\begin{array}{l}\text { Humerus } \\
\text { Humerus } \\
\text { Tibia }\end{array}$ & $\begin{array}{l}\text { Distal portion of shaft } \\
\text { Proximal portion of shaft } \\
\text { Distal portion of shaft }\end{array}$ & $\begin{array}{l}\text { Hand saw } \\
\text { Smooth blade cut } \\
\text { Hand saw }\end{array}$ & Arm roast & $\begin{array}{c}6+\text { knife around } \\
\text { circumference }\end{array}$ \\
\hline \multicolumn{7}{|c|}{ ROOM 0} \\
\hline $\begin{array}{l}1 \\
\frac{1}{2}\end{array}$ & $\begin{array}{l}\text { Mammalia (M/L) } \\
\text { Mammalia (L/VL) }\end{array}$ & $\begin{array}{l}\text { Sacrum } \\
\text { Fragment }\end{array}$ & $\begin{array}{l}\text { Centrum } \\
\text { Fragment }\end{array}$ & $\begin{array}{l}\text { Hand saw } \\
\text { Double hand saw }\end{array}$ & & $\begin{array}{l}\text { "L" cut longitudinal } \\
\text { and horizontal }\end{array}$ \\
\hline \multicolumn{7}{|c|}{ ROOM 1} \\
\hline $\begin{array}{l}1 \\
1 \\
1 \\
1 \\
1 \\
5\end{array}$ & $\begin{array}{l}\text { Mammalia (M/L) } \\
\text { Mammalia (M/L) } \\
\text { Mammalia (L/VL) } \\
\text { Mammalia (VL) } \\
\text { Artiodactyla (L) }\end{array}$ & $\begin{array}{l}\text { Indeterminate } \\
\text { Long bone } \\
\text { Femur } \\
\text { Tibia } \\
\text { Femur }\end{array}$ & $\begin{array}{l}\text { Fragment } \\
\text { Fragment } \\
\text { Fragment } \\
\text { Fragment } \\
\text { Proximal portion of shaft }\end{array}$ & $\begin{array}{l}\text { Double hand saw } \\
\text { Double hand saw } \\
\text { Double hand saw } \\
\text { Hand saw } \\
\text { Complete chop }\end{array}$ & Rump roast & \\
\hline
\end{tabular}




\begin{tabular}{|c|c|c|c|c|c|c|}
\hline \multicolumn{7}{|c|}{ Table 17 , continued } \\
\hline No. & Taxon (Size) & Element & Portion & Cut Type & Cut of Meat & Comments \\
\hline \multicolumn{7}{|c|}{ ROOM 2} \\
\hline $\begin{array}{c}1 \\
1 \\
1 \\
1 \\
1 \\
1 \\
1 \\
1 \\
1 \\
1 \\
1 \\
1 \\
1 \\
13\end{array}$ & $\begin{array}{l}\text { Mammalia (M/L) } \\
\text { Mammalia (M/L) } \\
\text { Mammalia (M/L) } \\
\text { Mammalia (V/L) } \\
\text { Mammalia (V/L) } \\
\text { Sus scrofa } \\
\text { Sus scrofa } \\
\text { cf. Sus scrofa } \\
\text { Bos } \text { sp. } \\
\text { Bos } \text { sp. } \\
\text { Bos } \text { sp. } \\
\text { Bos/Bison } \\
\text { Bos/Bison }\end{array}$ & $\begin{array}{l}\text { Indeterminate } \\
\text { Indeterminate } \\
\text { Vertebra } \\
\text { Indeterminate } \\
\text { Long bone } \\
\text { Permanent tooth } \\
\text { Tibia } \\
\text { Tibia } \\
\text { Radius } \\
\text { Radius } \\
\text { Ulna } \\
\text { Lumbar vertebra } \\
\text { Astragalus }\end{array}$ & $\begin{array}{l}\text { Fragment } \\
\text { Fragment } \\
\text { Saggital split, left portion } \\
\text { Fragment } \\
\text { Fragment } \\
\text { Lower C } \\
\text { Distal end } \\
\text { Diaphyseal fragment } \\
\text { Distal end } \\
\text { Proximal end } \\
\text { Proximal portion of shaft } \\
\text { Saggital split, right portion } \\
\text { Fragment }\end{array}$ & $\begin{array}{l}\text { Smooth blade cut } \\
\text { Double hand saw } \\
\text { Hand saw } \\
\text { Double hand saw } \\
\text { Double hand saw } \\
\text { Hand saw } \\
\text { Hand saw } \\
\text { Double hand saw } \\
\text { Hand saw } \\
\text { Hand saw } \\
\text { Hand saw } \\
\text { Hand saw } \\
\text { Double complete chop }\end{array}$ & $\begin{array}{l}\text { Round cut or discard } \\
\text { Hind foot } \\
\text { Hind shank } \\
\text { Round cut or discard } \\
\text { Shank knuckle } \\
\text { Shank knuckle } \\
\text { T-bone steak }\end{array}$ & $\begin{array}{l}\text { fits sawed ulna } \\
\text { fits sawed radius } \\
\text { also sawed on trans. } \\
\text { process }\end{array}$ \\
\hline \multicolumn{7}{|c|}{ ROOM 3} \\
\hline $\begin{array}{l}1 \\
1 \\
1 \\
1 \\
1 \\
1 \\
\frac{1}{7}\end{array}$ & $\begin{array}{l}\text { Anatidae } \\
\text { Mammalia (M/L) } \\
\text { Mammalia (M/L) } \\
\text { Mammalia (L/VL) } \\
\text { Mammalia (L/VL) } \\
\text { Mammalia (VL) } \\
\text { Sus scrofa }\end{array}$ & $\begin{array}{l}\text { Coracoid } \\
\text { Rib } \\
\text { Rib } \\
\text { Indeterminate } \\
\text { Indeterminate } \\
\text { Rib } \\
\text { Scapula }\end{array}$ & $\begin{array}{l}\text { Complete } \\
\text { Vertebral end } \\
\text { Shaft fragment } \\
\text { Fragment } \\
\text { Fragment } \\
\text { Shaft fragment } \\
\text { Blade portion }\end{array}$ & $\begin{array}{l}\text { Chop } \\
\text { Complete chop } \\
\text { Double complete chop } \\
\text { Incomplete chop } \\
\text { Cut } \\
\text { Chop } \\
\text { Hand saw }\end{array}$ & $\begin{array}{l}\text { Back rib } \\
\text { Spare rib }\end{array}$ & $\begin{array}{l}3+\text { disarticulation, } \\
2 \text { on shaft } \\
\text { multiple cuts } \\
\text { acid etched }\end{array}$ \\
\hline
\end{tabular}




\begin{tabular}{|c|c|c|c|c|c|c|}
\hline \multicolumn{7}{|c|}{ Table 17, continued } \\
\hline No. & Taxon (Size) & Element & Portion & Cut Type & Cut of Meat & Comments \\
\hline \multicolumn{7}{|c|}{ SOUTH PART OF BACK YARD } \\
\hline $\begin{array}{r}1 \\
1 \\
1 \\
1 \\
1 \\
1 \\
2 \\
2 \\
1 \\
1 \\
1 \\
1 \\
1 \\
1 \\
\frac{1}{16}\end{array}$ & $\begin{array}{l}\text { Vertebrata } \\
\text { Mammalia (M/L) } \\
\text { Mammalia (M/L) } \\
\text { Mammalia (M/L) } \\
\text { Mammalia (M/L) } \\
\text { Mammalia (M/L) } \\
\text { Mammalia (L/VL) } \\
\text { Mammalia (L/VL) } \\
\text { Mammalia (L/VL) } \\
\text { Mammalia (L/VL) } \\
\text { Mammalia (L/VL) } \\
\text { Mammalia (VL) } \\
\text { Sus scrofa } \\
\text { Bos/Bison }\end{array}$ & $\begin{array}{l}\text { Long bone } \\
\text { Indeterminate } \\
\text { Indeterminate } \\
\text { Femur } \\
\text { Long bone } \\
\text { Long bone } \\
\text { Indeterminate } \\
\text { Indeterminate } \\
\text { Indeterminate } \\
\text { Long bone } \\
\text { Long bone } \\
\text { Indeterminate } \\
\text { Tibia } \\
\text { Pelvis }\end{array}$ & $\begin{array}{l}\text { Distal articular condyle } \\
\text { Fragment } \\
\text { Fragment } \\
\text { Proximal portion of shaft } \\
\text { Distal portion of shaft } \\
\text { Proximal portion of shaft } \\
\text { Fragment } \\
\text { Fragment } \\
\text { Fragment } \\
\text { Fragment } \\
\text { Fragment } \\
\text { Fragment } \\
\text { Fragment } \\
\text { Ilium fragment }\end{array}$ & $\begin{array}{l}\text { Cut } \\
\text { Hand saw } \\
\text { Double hand saw } \\
\text { Hand saw } \\
\text { Hand saw } \\
\text { Hand saw } \\
\text { Double complete chop } \\
\text { Cut } \\
\text { Double complete chop } \\
\text { Double hand saw } \\
\text { Cut } \\
\text { Inc. chop w/hand saw } \\
\text { Cut } \\
\text { Double hand saw }\end{array}$ & $\begin{array}{l}\text { Round cut or discard } \\
\text { Sirloin }\end{array}$ & \\
\hline
\end{tabular}


recovered from the Kitchen area. Since none of the scales recovered are burned, it appears that the fish were scaled before cooking. The other 193 scales were recovered from the south portion of the back yard.

\section{Avian Butchering}

Only three avian elements exhibit butcher marks. These include the mourning dove carpometacarpus from the Kitchen area with the chopped distal condyle (mentioned above), a large bird distal tibiotarsus with disarticulation cuts across the condyles from the Kitchen area, and a duck complete coracoid with disarticulation cuts and cuts on the shaft from Room 3.

\section{Mammal Butchering}

The majority of the butchered specimens identified are from mammalian animals $(n=94,95$ percent), although the majority of these were identified simply to class (see Table 17). Of the specimens that could not be identified past class, one is from a small/medium-sized mammal, 38 are from medium-sized/large mammals, 23 are from large/very large mammals, and 14 are from very large mammals. Identified and butchered mammalian taxa are composed of artiodactyls only, primarily pig (including cf. pig) and cow (including cow/bison and cf. cow/bison).

Individual mammalian cuts identified are listed in Table 18. Beef values were adapted from Schulz and Gust (1983), who provide an ordinal listing of beef cuts from several areas of the United States between 1850 and 1910. Relative pig cuts are from Crader (1990). Based on comparison with these works, the pig and cow remains from Officers' Quarters 4 are generally better cuts of meat, although some cut pig and cuts from medium/large mammals do not appear to be as well ranked as the cow cuts of meat. Variation ranges in the rating of cow cuts from Schulz and Gust (1983) stem from the changes in values of the cuts between years and geographical areas as a result of economic variation, differences in actual cuts, and cultural (i.e., regional?) preferences (Schulz and Gust 1983:12-15). By using these references for comparison, it is clear that the officers of Officers' Quarters 4 were provided with a variety of generally better cuts of meat.

\section{TAXA DESCRIPTIONS}

As a supplement to the text and Tables 12 and 13, a discussion of selected taxa is presented. This discussion is meant as a supplement to the taxa list for understanding how identifications were made for unique observations and explanation of generic sizes. Where applicable, Tables 12 and 13 provide basic information. Note that the identifications are made to the most specific level possible. Most specimens could not be more specifically identified due to taphonomic factors.

Osteichthyes (Small, medium, large, and cf. for the sizes): Unidentifiable fish elements were placed within size categories based primarily on measurement of vertebral centrum widths. Those centra less than $5 \mathrm{~mm}$ are described as small fish, equal to or greater than $5 \mathrm{~mm}$ but less than $15 \mathrm{~mm}$ are listed as medium fish, and those centra equal to or greater than $15 \mathrm{~mm}$ are listed as large fish. Elements that could not be measured were estimated as to the size of fish from which they originated. These specimens are denoted with a "cf." for the size. A variety of cranial and postcranial elements were recovered, but most are scales. Fish scales recovered were identified as catenoid $(n=975)$ and cycloid $(n=1)$; fragmented or degraded scales are described as unidentified $(n=53)$. Surprisingly, most of the scales are fairly large and measure between 0.5 and $1.0 \mathrm{~cm}$.

Ictalurus sp. (Catfish) and I. punctatus (Channel catfish): Catfish were identified based on cranial elements and pectoral spines. Since most of the specimens are fragmentary, more-specific identifications could not be made, except for one pectoral spine that was identified as channel catfish.

Anura (Toads and frogs): Two humerus fragments were found.

Testudinata (Turtles): Specimens identified to this level consist of shell elements.

Trionyx sp. (Softshell turtle): Softshell turtle is readily recognized by the dimpled or golf ball-like patterning on the outer surface of the shell. Only shell fragments were identified as softshell turtle.

Colubridae (Colubrid snakes): Colubrid snakes were identified on the basis of a reduced ventral process.

Aves (Medium birds; large birds; birds, size unknown): Medium birds are those the size of blue jays, large birds are duck, chicken, turkey, or goose sized. Most of the unidentified large bird specimens 
TABLE 18

TAXA, ELEMENTS, MEAT CUTS, AND FREQUENCIES FOR MAMMALS*

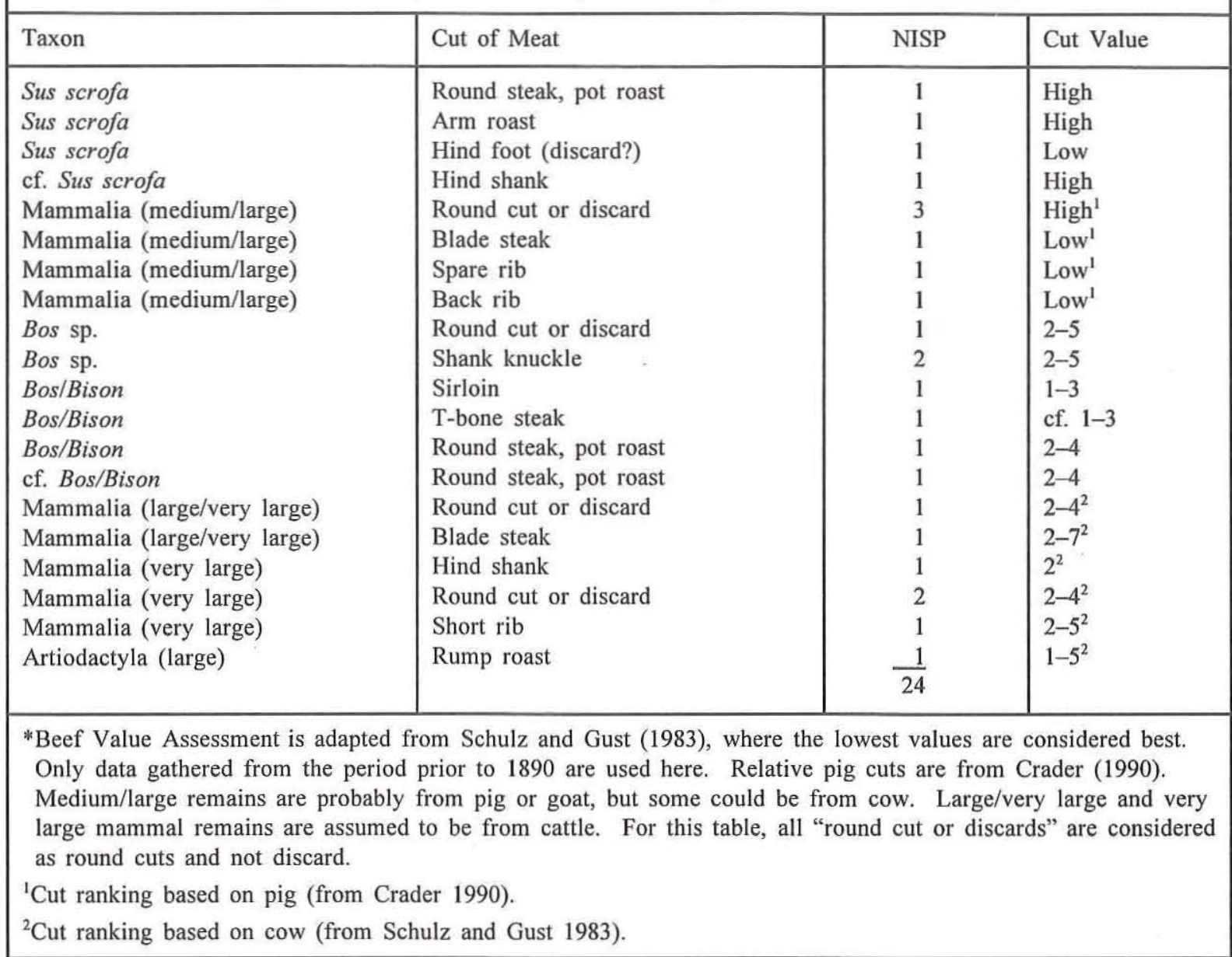

are probably chicken or turkey but may be duck. Of unique interest was the recovery of eggshells indicating that birds were raised on-site.

Anatidae and cf. Anatidae (Ducks): Due to a lack of comparative materials and multiple genera of both ducks and geese, specimens were identified to the family level only. Identified duck elements include pectoral girdle elements only.

Phasianidae (Quail): One coracoid and tarsometatarsus were identified as quail.

Gallus gallus and cf. G. gallus (Domestic chicken): A variety of cranial and postcranial chicken elements were recovered, but no attempt was made to identify particular breeds. Chickens are not native to North America.

Meleagris gallopavo and cf. M. gallopavo (Turkey): The remains of turkey identified include a femur, phalanges, carpometacarpus, and vertebra.
Based on information provided by Sullivan (1993: 53-54), these turkey remains probably derived from hunted wild specimens and not domesticated specimens.

cf. Numida sp. (Guineafowl): The identification of guineafowl was based on the recovery of a single tibiotarsus. Based on comparison with comparative osteological material, this taxon most closely matches the archeological specimen. These birds are not native to North America and were introduced by colonists.

cf. Columba sp. (Pigeons and doves): One front (wing) proximal phalange was identified as pigeon. This specimen closely resembles that of a rock dove (Columba livia), although the smaller passenger pigeons (Ectopistes migratorius), now extinct, are in the same family, Columbidae. Since no comparative materials were available for passen- 
ger pigeons, the tentative identification was made based upon comparison with rock dove.

cf. Zenaida sp. (Doves): One cut carpometacarpus was recovered. Mourning dove are common in Texas.

Lepus sp. (Jackrabbits): Seven elements were recovered, including a mandible, scapula, ulna, pelvis, metacarpal, and phalange.

Sylvilagus sp. and cf. Sylvilagus sp. (Cottontail rabbits): Specimens identified as cottontail could be from the eastern cottontail (S. floridanus) or the desert cottontail (S. auduboni) since Fort McKavett is within the known range of each (Davis 1978: 236-244). Based on assessing age using bone fusion and deciduous teeth, at least one juvenile is represented. A variety of elements were recovered from throughout the skeleton.

Rodentia (Small and medium): Small rodents are those the size of mice. Medium-sized rodents are rat and squirrel sized. Small rodents are represented by a cranium calvarium and medium rodents by a pelvis fragment and tibia.

Sciuridae (Squirrels and chipmunks): All of the specimens identified as Sciuridae are the size of squirrels but were not diagnostic for identification to genus. These specimens are probably from fox squirrel (Sciurus niger) or rock squirrel (Spermophilus variegatus) which both currently occupy the region (Davis 1978:152-162). Recovered elements include a cranial fragment, mandibular fragment, tooth, atlas, axis, radius, ulna, femur, and two pelvis fragments.

Peromyscus sp. and cf. Peromyscus sp. (Mice): This genus includes a variety of mice, but identification could not be more specific due to a lack of comparative materials for the species that occur in the area. Specimens recovered include two crania and associated teeth. These two specimens are the only identified mice specimens, and both were recovered from the same lot as the domestic cat in Room 3.

Felis domesticus and cf. F. domesticus (Domestic cat): Based on bone fusion and deciduous teeth, at least three domestic cats are represented in this assemblage. These include the adult cat skeleton in Room 3 ( $\mathrm{n}=126$ bones), other adult long bones found in other areas, and a kitten's mandible also from Room 3. In total, 158 cat remains were recovered from the Kitchen area and Rooms 0-3.

Artiodactyla (Medium and large): Deer/ pronghorn-sized ungulates comprise the medium artiodactyls, although sheep, goat, and large pig remains potentially fall into this category as well. Large ungulates are potentially cattle or bison, but since no bison were recovered from Fort McKavett and none are referenced by Sullivan (1993), it is believed that all of the large artiodactyl remains represent domestic cattle (Bos sp.)

Odocoileus sp. (Deer): Seven specimens were identified as deer. Except for two teeth, all are leg elements.

Sus scrofa and cf. S. scrofa (Pig): At least four individuals are represented in this assemblage- two adults and two juveniles based on assessment of the teeth and long bone fusion. Based on teeth, at least two juveniles are represented (from duplication of deciduous upper left 3rd premolars) and one adult based on the presence of two upper 1st molars, one with slight and one with moderate wear. Additional specimens from adults and juveniles were identified in the postcranial assemblage but were not present in high enough frequencies to change the MNI estimation based on cranial remains.

Bos sp. and cf. Bos sp. (Cow) and Bos/Bison and cf. Bos/Bison (Cattle/bison): Specimens identified to any one of these categories are probably domestic cow. No bison remains were recovered, and Sullivan (1993) does not mention bison as a food resource for the Fort McKavett occupants. Elements recovered include limb elements primarily, but three teeth were also recovered.

Capra hircus (Goat) and Ovis/Capra and cf. Ovis/Capra (Sheep/goat): Goat and sheep/goat remains are probably all goat remains as indicated by the lack of any positively identified sheep remains, although Sullivan (1993:57-58) mentions that, after abandonment in 1883, the area around the fort did have commercial sheep ranches (along with other bovids).

Equus sp. (Horses and relatives): Horse is represented by one permanent upper cheek tooth fragment.

\section{UNIQUE OBSERVATIONS AND NONECONOMIC TAXA}

Several aspects of the Officers' Quarters 4 assemblage are unique and do not fall into the normal discussions of animal exploitation and economics. These topics include the presence of commensal or intrusive taxa, possible walling up of dead cats, lack of gopher remains, and animal pathologies. 


\section{Commensal or Intrusive Taxa}

Several taxa present at Officers' Quarters 4 could not be identified definitively as culturally procured, commensal, or intrusive. These include snakes, rodents (squirrels and mice), and leporids (jackrabbits and cottontails). As mentioned earlier, they occur in the highest frequencies associated with cat remains in the structures of the kitchen and Rooms $0-3$. The status of the cat may be listed as potentially intrusive, commensal, or possibly the result of a unique architectural Old World ritual of walling cats into buildings (discussed in next section).

The only evidence of more-recent intrusive taxa comes from Rooms 0,1 , and 3. In Room 0 , the cranium calvarium of a small rodent was recovered. This specimen appears to be in better condition than most of the other faunal materials and therefore may be more recent then the rest of the materials. From Room 1, a left cottontail mandible and associated teeth were recovered that also are unstained and apparently more recent than the rest of the Fort McKavett materials. Additionally, a right mandible and associated teeth, a scapula fragment, a complete left femur (with carnivore marks noted above), and a metatarsal match the description of the left mandible and therefore may be more recent. Lastly, from Room 3, the remains of a nonpoisonous snake (Colubridae, $\mathrm{n}=13$ vertebrae) were recovered. There is no indication that this specimen was deposited as the result of cultural activities. Two more colubrid vertebrae were recovered from the kitchen area as well.

\section{Walling Up Cats?}

Of unique interest is the recovery of the majority of a mature adult cat skeleton (minus head, jaws, and various small bones) and the recovery of two mouse skulls (Peromyscus sp.) and a small rodent (mouse?) long bone from the same lot as the cat. The mouse remains do not show any signs of gastric acid etching that would indicate that they were derived from the stomach contents or are of scatological origin. Thus, the association of the cat and the mice does not represent a dinner relationship. The cat could have died under Room 3, and the association with the mouse elements and other fauna could be pure coincidence. However, there is another unique possibility. The association of the cat and the rodents may also represent a superstitious European building practice (Clutton-Brock 1981:111-112; Howard 1951; Hyams 1972:43).

Walling cats into buildings in England and other parts of Europe apparently was fairly common. The practice included placing a dead cat in a sealed context of the building, often in a wall, but sometimes under a floor or in the roof or other part of the structure. Howard (1951) noted 25 examples spanning from the thirteenth to the twentieth century, mostly in England. Possible reasons for the walling up of cats include foundation sacrifices, vermin scares, and accidental enclosures. Six specimens are listed by Howard (1951) as vermin scares, five of which had associated rodents, two of which had rodents in the cats' mouths, and one with a cat pegged down near a rat. The apparent concept is that the cat would act as a scarecrow, terrifying any living rodent that ventured close!

\section{Gopher Remains}

One surprising aspect of the Fort McKavett assemblage is the lack of gopher remains. Apparently, sediments from Officers' Quarters 4 were bioturbated, probably by gophers or other rodents (Amy Earls, personal communication 1995). However, the only rodent remains recovered are those of squirrel and mouse. These taxa may burrow as well and turbate sediments. Thus, the Officers' Quarters 4 assemblage shows that while gophers often are attributed with disturbing archeological sites, they, in fact, may not be present in the assemblage and thus probably are not the primary agent responsible.

\section{Pathologies}

Five specimens were identified with pathological conditions, three of which were chronic conditions, one congenital, and one traumatic. All three of the chronic conditions were noted on Capra hircus (goat) proximal phalanges with pronounced enthesophytic growth on the posterior side where the palmar (or plantar, depending on front or hind foot) ligament attaches. Specimens were recovẹred from Room 0, Room 1, and the back yard.

The one congenital defect is a pig right lower fourth permanent premolar that is rotated in its mandibular socket (Room 0). The proximal or anterior end of the tooth is rotated lingually and does not align with the length of the mandible. 
This probably did not interfere with mastication, although the lack of wear on this and associated teeth indicates that the pig died while relatively young.

The traumatic condition is a healed broken right femur of the domestic cat recovered from Room 1. The midshaft fracture did not set properly and the ends rejoined laterally, resulting in a large callous around the bone (Figure 69) and a reduced length of $89.2 \mathrm{~mm}$ from the $98.8 \mathrm{~mm}$ estimated from its matching counterpart. In relation to the distal end, the proximal end's medial and slightly posterior portion of the shaft rejoined the distal end's lateral and anterior portion of the shaft. The proximal end of the bone is tilted laterally at an angle (approximately $20^{\circ}$ ) from the distal end of the bone. The orientation of the femoral head, however, appears to have remained correct, and the misaligned bones had not twisted before setting. The trochanter area of the femur appears slightly asymmetrical when compared to the unaffected left femur, indicating a slight change in muscle use after the fracture. Based on the size of the callous and the amount of remodeling, this fracture had been healed for a long period of time before the cat's death. No arthritic build up was observed on either the proximal or distal articular surfaces, as would be expected from a misaligned and healed traumatic injury to a locomotor element such as a femur. Based on the reduced length of the femur due to misalignment of the fractured ends, the cat probably walked with a considerable limp.

\section{DISCUSSION}

A variety of taxa were recovered from Officers' Quarters 4 at Fort McKavett. Most of these are taxa expected to be recovered from a fort and surrounding community dating to the mid-nineteenth through twentieth centuries. Most of the taxa recovered match the historical descriptions provided by Sullivan (1993), although additional taxa are present in the actual faunal materials, such as domestic cat, chicken, and some of the nondomestic fauna.

The composition of probable food remains is dominated by domestic taxa such as pig, cow, and

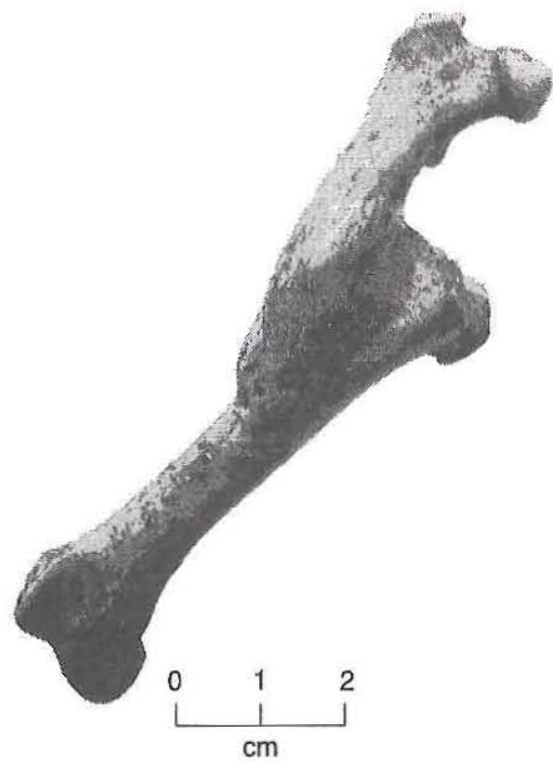

Figure 69. Felis domesticus right femur with healed fracture.

goat, although wild taxa such as fish, turtle, turkey, rabbit, squirrel, and deer are present as well in low numbers. Within Officers' Quarters 4, the cuts of meat recovered appear to be relatively good but varied, indicating that officers ate fairly well. The fact that the diet was supplemented by wild taxa is not an indicator of food stress but an indicator of diversity in diet that was provided by hunting (which served as a means of diversion against boredom at the fort).

Of unique interest is the lack of recovery of many intrusive or commensal animals. While the rodent, snake, and possibly rabbit remains may fall into this category, it is surprising to find so few rodents and no gopher remains, although the fort grounds were reported as turbated (probably by rodents). The one bizarre find is that of a nearly complete domestic cat skeleton in (potentially coincidental) association with the remains of two mice in Room 1. While these remains may be commensal or intrusive into the site, the cat and associated mice remains may correspond to the Old World practice of walling cats into structures as vermin scares. 


\section{REFERENCES CITED}

Auffenberg, W.

1969 The Fossil Snakes of Florida. Tulane Studies in Zoology 10:131-216.

Balkwill, D. M., and S. L. Cumbaa

1992 A Guide to the Identification of Postcranial Bones of Bos taurus and Bison bison. Syllogeus No. 71. Canadian Museum of Nature, Ottawa.

Calovich, F. E., and B. A. Branson

1964 The Supraethmoid-Ethmoid Complex in the American Catfishes, Ictalurus and Pylodictis. The American Midland Naturalist 71:335-343.

Clutton-Brock, J.

1981 Domesticated Animals: From Early Times. University of Texas Press, Austin.

Crader, D. C.

1990 Slave Diet at Monticello. American Antiquity 55:690-717.

Davis, W. B.

1978 The Mammals of Texas. Bulletin No. 41. Texas Parks and Wildlife Department, Austin.

Efremov, J. A.

1940 Taphonomy: A New Branch of Paleontology. Pan-American Geologist 74:81-93.

Glass, B. P.

$$
\begin{aligned}
& 1951 \text { A Key to the Skulls of North American } \\
& \text { Mammals. Burgess Publishing Co., } \\
& \text { Minneapolis, Minn. }
\end{aligned}
$$

Hillson, S.

1986 Teeth. Cambridge University Press, Cambridge.

Howard, M. N.

1951 Dried Cats. Man 51. London.

Hubbs, C., Robert J. Edwards, and Gary P. Garrett

1991 An Annotated Checklist of the Freshwater Fishes of Texas, With Keys to Identification of Species. Texas Journal of Science 43(4): Supplement issue.

Hyams, E.

1972 Animals in the Service of Man. J. B. Lippincott Company, Philadelphia.

Johnson, E.

1985 Current Developments in Bone Technology. In
Advances in Archaeological Method and Theory, vol. 8, edited by M. B. Schiffer, pp. 157-235. Academic Press, New York.

Lawrence, B.

1951 Post-cranial Skeletal Characters of Deer, Pronghorn, and Sheep-goat with Notes on Bos and Bison. Papers of the Peabody Museum of Archaeology and Ethnology 35(3):9-43. Harvard University, Cambridge.

Mundell, R. L.

1975 An Illustrated Osteology of the Channel Catfish (Ictalurus punctatus). Occasional Studies in Anthropology No. 2. Midwest Archeological Center, National Park Service, Lincoln, Nebraska.

Olsen, S. J.

1960 Post-Cranial Skeletal Characters of Bison and Bos. Papers of the Peabody Museum of Archaeology and Ethnology 35(4). Harvard University, Cambridge.

1964 Mammal Remains from Archaeological SitesPart I, Southwestern and Southeastern United States. Papers of the Peabody Museum of Archaeology and Ethnology 56(1). Harvard University, Cambridge.

1968 Fish, Amphibian and Reptile Remains from Archaeological Sites. Papers of the Peabody Museum of Archaeology and Ethnology 56(2). Harvard University, Cambridge.

Peterson, R. T.

1963 A Field Guide to the Birds of Texas and Adjacent States. Houghton Mifflin Company, Boston.

Robbins, C. S., B. Bruun, and H. S. Zim

1983 A Guide to Field Identification Birds of North America. Golden Press, New York.

Schmid, E.

1972 Atlas of Animal Bones. Elsevier Publishing Company, New York.

Schulz, P. D., and S. M. Gust

1983 Relative Beef Cut Prices in the Late Nineteenth Century: A Note for Historic Sites Faunal Analysts. Pacific Coast Archaeological Society Quarterly 19(1):12-18. 
Shaffer, B. S., and B. W. Baker

1992 A Vertebrate Faunal Analysis Coding System: With North American Taxonomy and dBase Support Programs and Procedures (Version 3.3). Technical Report 23. Museum of Anthropology, University of Michigan, Ann Arbor.
Sullivan, J. M.

1993 Fort McKavett: A Texas Frontier Post. Reprint. Texas Parks and Wildlife Department, Austin. Originally published 1981, The Museum Journal 20. West Texas Museum Association, Texas Tech University, Lubbock. 
